\title{
Rebuild America Program Scope of Work
}

\section{Final Technical Report}

Start Date: October 8, 1999

End Date: $\quad$ October 31, 2004

Principal Authors:

Jeffrey Brown

Bruce Exstrum

December 2004

Contract No. GS-10F-0070J

Task Order No. DE-AD26-99FT40235

Aspen Systems Corporation

2277 Research Boulevard

Rockville, MD 20850 
This report was prepared as an account of work sponsored by an agency of the United States Government. Neither the United States Government nor any agency thereof, nor any of their employees, makes any warranty, express or implied, or assumes any legal liability or responsibility for the accuracy, completeness, or usefulness of any information, apparatus, product, or process disclosed, or represents that its use would not infringe privately owned rights. Reference herein to any specific commercial product, process, or service by trade name, trademark, manufacturer, or otherwise does not necessarily constitute or imply its endorsement, recommendation, or favoring by the United States Government or any agency thereof. The views and opinions of authors expressed herein do not necessarily state or reflect those of the United States Government or any agency thereof. 


\begin{abstract}
This report summarizes the activities carried out by Aspen Systems Corporation in support of the Department of Energy's Rebuild America program during the period from October 9, 1999 to October 31, 2004. These activities were in accordance with the Scope of Work contained in a GSA MOBIS schedule task order issued by the National Energy Technology Laboratory. This report includes descriptions of activities and results in the following areas: deployment/delivery model; program and project results; program representative support activities; technical assistance; web site development and operation; business/strategic partners; and training/workshop activities. The report includes conclusions and recommendations. Five source documents are also provided as appendices.
\end{abstract}




\section{CONTENTS}

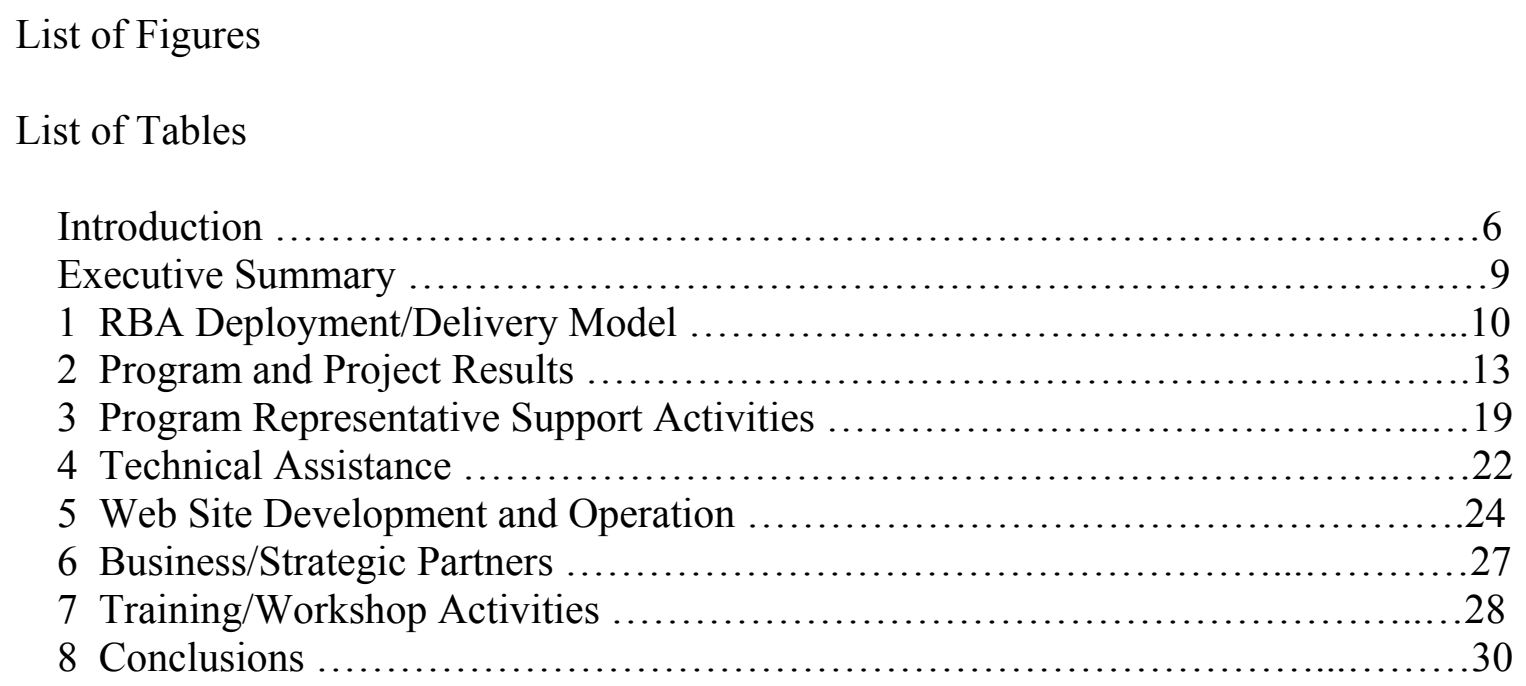

\section{APPENDICES}

Appendix A: Action Plan Check-List

Appendix B: Rebuild America Program Manual

Appendix C: Rebuild America 2004: Program Accomplishments and Analysis

Appendix D: Rebuild America: 2004 Operational Plan and Deliverables Matrix

Appendix E: Regional Rebuild America Marketing and Customer Service Plan for 2000 


\section{LIST OF FIGURES}

Figure 1: Current and Projected Square Footage Commitments 14

Figure 2: EERE Regions 16

Figure 3: From Prospect to Action 21

\section{LIST OF TABLES}

Table 1: Aspen Systems Contract Budgets and Labor Commitments 8

Table 2: Summary of Program Results 17

Table 3: Rebuild America National Program Results Summary as of 10/31/04 18

Table 4: Program Representative Activity Levels 20

Table 5: Key Program Training Activities 29 


\section{Introduction}

Historically, the Federal government has faced the problem of how best to provide support, guidance, and incentives to communities to meet national goals and priorities. No one solution fits every community. The size, density and diversity of our communities certainly set challenges for national energy efficiency programs. Resource availability, price differentials, age of building stock, and other regional characteristics influence the solutions best suited for a specific community.

In response to this challenge, in 1995 the Office of Energy Efficiency and Renewable Energy (EERE) of the Department of Energy developed the Rebuild America Program (RBA). Since 1997, Aspen Systems Corporation has been a major participant in supporting this important program, most recently through a 5-year GSA MOBIS Schedule subcontract with the National Energy Technology Laboratory. This report is the final deliverable under that contract.

Rebuild America assists participating communities design and implement energy-saving projects that respond to their individual circumstances and goals, providing access to a portfolio of technical assistance, with a core focus on existing commercial and institutional buildings. The general target market includes new and existing public and multifamily housing, commercial buildings, and all types of local/state government and educational facilities.

To join Rebuild America, a community organization initiates a partnership with local or state government, utilities, building owners, civic and environmental leaders, school administrators, non-profits, and economic development organizations. Communities then establish priorities for building improvements. As a group, they choose target buildings, set goals for energy savings, look for ways to finance the projects, and decide how to coordinate and mobilize their efforts. Rebuild America partnerships are designed around local priorities and actions. Retrofit projects often focus on municipal buildings, college campuses, public schools, main street business districts, historic landmarks, or community housing.

The RBA Vision is to have communities across America that use energy efficiency and renewable energy to improve their lives at work, at home and at play.

The RBA Mission is to build partnerships among communities, states, and the private sector to improve building performance and connect people, resources, ideas and practices for energy solutions to community needs.

The RBA vision and mission are consistent with the Department of Energy's role of providing America with a stronger economy, a healthier environment, and a more secure future by increasing the efficiency of the nation's energy system. The vision and mission supports EERE in its goals of facilitating the deployment of advanced energy efficiency and renewable energy technologies and practices.

The RBA program was established in 1994 to accelerate the adoption of energy efficiency measures and practices in existing public facilities, commercial buildings, and 
multifamily housing units. More recently, the program has expanded to include new construction as well. The program encourages the formation of partnerships involving state and local governments, private businesses, and other organizations to help identify and solve problems related to energy use in buildings. Rebuild America does not directly fund building improvements. Instead, it provides RBA partnerships with the technical tools and assistance they need to plan and implement building projects and stimulates other entities to make substantial investments in energy efficiency.

Under the contract with NETL, Aspen's main role in the RBA program is to support and coordinate the customer service components of the program and to provide planning and integration services at the overall program level. Aspen's Statement of Work includes the following key activities:

- Delivery of technical assistance through consultation and training to communities on the full range of issues they will need to address to develop and implement Rebuild America Action Plans, including accounting for technical, market, financial, legal and public (or stakeholder) participation issues

- Effective leveraging and utilization of information and resources available from existing federal, state, local and private-sector programs and initiatives that deal with community redevelopment and implementation of energy efficient measures and technologies.

- Providing assessments and consultation on energy efficient technologies, as well as accessing needed technical expertise at the national laboratories and other institutions and organizations.

- Maintaining and coordinating the network of Rebuild America program representatives, including developing and facilitating effective working relationships with representatives of energy efficiency programs associated with the DOE Regional Offices and the State Energy Offices.

- Facilitating the flow of information and ideas between community partnerships

- Conducting program analyses that track and report on the performance of Rebuild America

Aspen's annual levels of support to the RBA program are summarized in Table 1. 
Table 1

Aspen Systems Contract Budgets and Labor Commitments

\begin{tabular}{|c|c|c|}
\hline Year & Total Cost & Labor Services (1) \\
\hline 1999 & $\$ 898,339$ & $8 \mathrm{FTE}$ \\
\hline 2000 & $\$ 1,310,492$ & $12 \mathrm{FTE}$ \\
\hline 2001 & $\$ 2,943,660$ & $17 \mathrm{FTE}$ \\
\hline 2002 & $\$ 3,848,800$ & $21 \mathrm{FTE}$ \\
\hline 2003 & $\$ 3,440,000$ & $19 \mathrm{FTE}$ \\
\hline 2004 & $\$ 2,550,000$ & $16 \mathrm{FTE}$ \\
\hline
\end{tabular}

(1) FTE = full-time equivalent per year

Over the course of the NETL contract period of performance, Aspen's portfolio of assignments has expanded in response to program requests. In 1999 Aspen added 3+ field staff to cover additional regions in the country. In 2000, Aspen added an additional field representative, multifamily housing capability through the HUD/DOE Interagency Agreement, initiated the Business Partners (Section 7) effort and was asked to takeover maintenance and development of the Rebuild web site (Section 6). In 2001 Aspen developed the Strategic Partners initiative (Section 7) and added staff to support that effort. The Products and Services component of Rebuild was transferred to Aspen from PNNL (Section 5), and Energy Smart Schools was created and the coordinator for that effort was provided through Aspen. In addition, Aspen was asked to develop and launch a new customer centric website containing public and private network components. In 2002 Aspen were asked to take over the distribution and clearinghouse component of the program (Section 5). 


\section{Executive Summary}

In 1999, the Federal Government inaugurated a program call Rebuild America to help local communities meet the challenges of reducing energy costs and improving long-term energy efficiency in their public and commercial buildings. From the beginning of the program, Aspen Systems Corporation has been a key support contractor to the Department of Energy's Office of Energy Efficiency and Renewable Energy (EERE). From October 8, 1999 to October 31, 2004, Aspen provided this support under a GSA MOBIS task order issued by DOE's National Energy Technology Laboratory (NETL). This document is the final report required under the terms of that contract.

During the contract period of performance, in addition to its continuing role in the customer service and program management activities, Aspen was asked to take on initiatives to greatly improve the program's website capabilities; expand and enhance the Business and Strategic Partner activities; and improve customer access to a wide range of technical resources. The following report documents and summarizes the work performed by Aspen during the contract period. It also contains conclusions and recommendations for future program directions and activities. 


\section{RBA Deployment/Delivery Model}

"The term "program logic" refers to the intended process by which a program achieves its objectives. For Rebuild America, a simplified version of the program logic is as follows. Through the formation of community partnerships (and the establishment of business and strategic partners), key actors in the institutional, commercial, and multi-family residential building sectors are brought together and important information on energy-efficient products and techniques is disseminated to the relevant parties. Assistance and training from technical experts are provided to the parties needing it, and help with key decisions is provided through peer exchanges of information and advice. Through this process, appropriate projects are identified, financing is arranged, resources are invested, and technical issues are resolved. This in turn leads to the increased use of energy-efficient technologies, the increased availability of relevant products, and the accelerated adoption of energy-efficient measures and practices. Ultimately, the building improvements carried out under the program result in energy and cost savings for program participants and environmental benefits for the larger society.",

The success of RBA lies in its nonprescriptive approach to community-based energy efficiency planning and implementation. By providing broad guidelines on commitments and making available a wide variety of technical, financial, and other resources, RBA allows communities to craft unique solutions to their local needs. RBA plugs communities into networks that make it easier to find solutions to building energy efficiency problems. Its customer service network works with communities to design, develop, and implement community action plans.

The Rebuild America Program is operated with a National Management Team and six Regional Teams. The National Management Team is responsible for establishing budgets and is accountable for ensuring performance of the Rebuild America program. The National Management Team includes the following functions:

- Policy and Management. Assure effective planning, decision-making, and evaluation of the Rebuild America Program. Management is carried out through a Program Management team made up of individuals responsible for various program functions.

- Customer Service. Recruit qualified partners, develop effective partnerships, and coordinate contacts and assistance services that aid them in planning and carrying out retrofit projects. Activities will be managed in order to: (a) identify and recruit qualified partners into the program; (b) assist partners in partnership formation during

\footnotetext{
${ }^{1}$ Martin Schweitzer and Laura Ogle-Graham, An Examination of Rebuild America Partnership Accomplishments and the Factors Influencing Them, ORNL/CON-490, Oak Ridge National Laboratory, September 2003. p. 2
} 
their initial development stage; (c) assure continuing partnership follow-up, including brokering services to meet their implementation needs; (d) quantify benefits and value that partners gain from the program; (e) train and coordinate program representatives and regional teams, to assure sound field management and continuing contacts needed to recruit and deliver services to partners; and (f) develop and maintain strategic partnerships with stakeholder groups.

- Products and Services. Develop or adapt, and deliver products and services that will help partnerships plan and carry out energy efficiency projects. Outputs include written guides, analytical software, workshops, and direct technical assistance.

- Business Partners. Provide Program Representatives and partnerships an avenue to access private sector products and services.

- Strategic Partners. Access resources of national associations and organizations that also serve program stakeholders.

- Marketing and Communications. Communicate Rebuild America activities and achievements, create and distribute general and targeted program marketing materials, and ensure that internal and external communications are effective and well supported.

Regional teams include Regional Team Leaders, DOE Regional Offices, and Program Representatives.

The key interface between RBA and its target markets is provided by its network of Program Representatives. This cadre of Representatives (Reps) work for a wide variety of organizations, from U.S. DOE , State Energy or other offices, National Laboratories, non-profit organizations, and contractors. Program Representatives have overall responsibility for conveying the concept and services of the Rebuild America program and for assuring that each partnership develops a sound Action Plan containing clear goals and a realistic implementation strategy. They aid the partnership in identifying specific assistance needs essential to carry out their implementation strategy, coordinate with RBA staff in the delivery of assistance, and report on the activities and successes of the partnership. They also aid in identifying and developing partnerships.

As part of its Customer Service responsibilities, Aspen created a regional team-based approach for delivering local customer service support where the assigned Program Representative "owns" the customer. The system has a three tier approach with the State Energy Office managing all state based activities. The SEO staff is supported by an Aspen employee who works with multiple states within a DOE region. All activities within a DOE region are managed by a DOE staff person, who ensures delivery of programmatic resources and support. This innovative structure of blending federal, state, and contractor resources has proven to be an extremely effective means of delivering resources from multiple entities in a seamless manner to the customer. 
To support effective coordination and integration of multiple program team members including over a dozen contractors, 6 Regional Offices, 52 states and territories, Aspen also developed program-wide management plans and resource materials. Aspen created a comprehensive Rebuild America Program Manual that outlined, in detail, all of the program processes and program roles and responsibilities. The manual provides a description, purpose and process for each program element. The manual is segmented by each discreet process identifying its date and staff responsibility, allowing change to specific processes without changing the entire manual. The manual is downloadable online in its entirety or by sub-chapter.

Aspen also created an annual operations plan for Rebuild America, which contains all the activities needed for a fully functioning program. The plan is organized based on the goals of the program's strategic plan, and laid out all tasks for each programmatic line function; customer service, website, products and services, marketing and communications, and headquarters management.

At the regional level, Aspen has assisted the six DOE Regional Offices in developing and implementing a Regional Marketing and Implementation Plan. These plans provide the foundation for achieving RBA's goals and objectives by developing those goals and objectives from the bottom up. Regional Marketing Plans act as the Action Plan for the Regional Offices to support, form, expand, and sustain partnerships and achieve national objectives. The Marketing plan includes regional Peer Exchange programs, which are tailored to meet the unique needs of partnerships in each region. Each Regional Marketing Plan has specific goals and targets, which feed into the goals and targets of the national program.

As indicated in the earlier description of management team functions, the Program Representatives and regional teams are backed up by a range of supporting resources and functions. Aspen has managed and/or participated in several of those activities, which are discussed in the remaining sections of this report. 


\section{Program and Project Results}

\section{$\underline{\text { Program Goals/Metrics }}$}

The quantitative goals for the Rebuild America program are expressed in target levels of benefits to be gained from program-supported incremental energy efficiency improvements (energy savings, energy cost savings, carbon emissions reductions) and the level of efficiency improvements to the building stock (defined as square feet of space committed to improvement) needed to achieve these benefits. As of FY 2004, the target program benefits are:

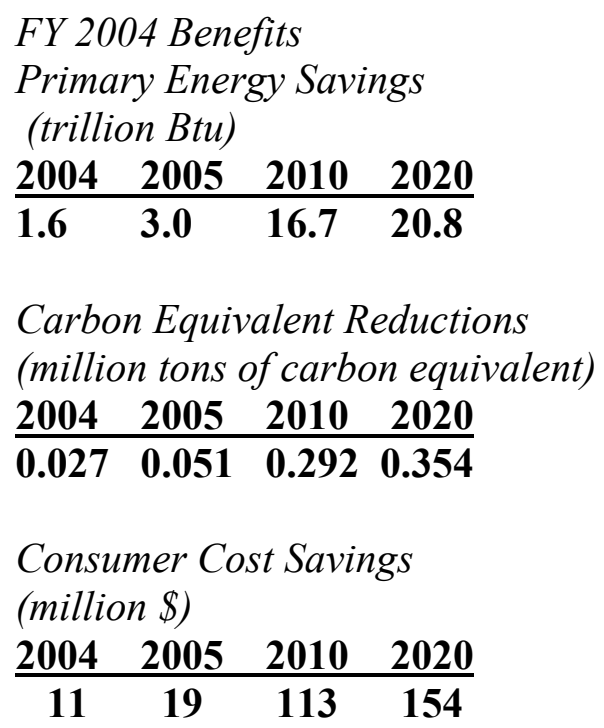

The related target penetration rates for retrofitting building space are:

\begin{tabular}{|l|c|r|r|}
\hline \multirow{2}{*}{\multicolumn{1}{|c|}{ Building Type }} & \multicolumn{3}{c|}{ Penetration Rates (\%) } \\
\cline { 2 - 4 } & $\mathbf{2 0 0 4}$ & $\mathbf{2 0 1 0}$ & $\mathbf{2 0 2 0}$ \\
\hline Targeted Commercial Buildings & 0.20 & 2.20 & 2.60 \\
\hline Multifamily & 0.20 & 2.20 & 2.60 \\
\hline Single Family & 0.01 & 0.07 & 0.08 \\
\hline
\end{tabular}

These benefits and penetration rate targets are realized by the development and implementation of specific energy efficiency projects by Rebuild America partnerships. The current overall Rebuild America target is to have 3.0 billion square feet of building space committed to retrofit by 2010. 


\section{$\underline{\text { Program Accomplishments }}$}

Based on information collected from partnerships, by September 2004 a total of 1.576 billion square feet of space had been committed to retrofit under the Rebuild America program. These projects were estimated to yield annual costs savings of $\$ 388$ million and annual energy savings of 85 million MMBtu. Of the total square footage, 776 million square feet was "committed" (project identified and/or in progress) and 800 million square feet was "completed" (retrofits completed). Starting in 2001, when detailed program data collection was initiated, total program square footage has grown from 700 million square feet (2001) to 1.576 million in 2004, a 125 percent increase over a three-year period. As shown in Figure 1, if the growth rates realized in this 2001-2004 period are extrapolated into the future (using simple linear regression analysis) the goal of 3.0 billion square feet committed to retrofit will be realized on or before the end-2010 target date.

\section{Figure 1}

Current and Projected Square Footage Commitments

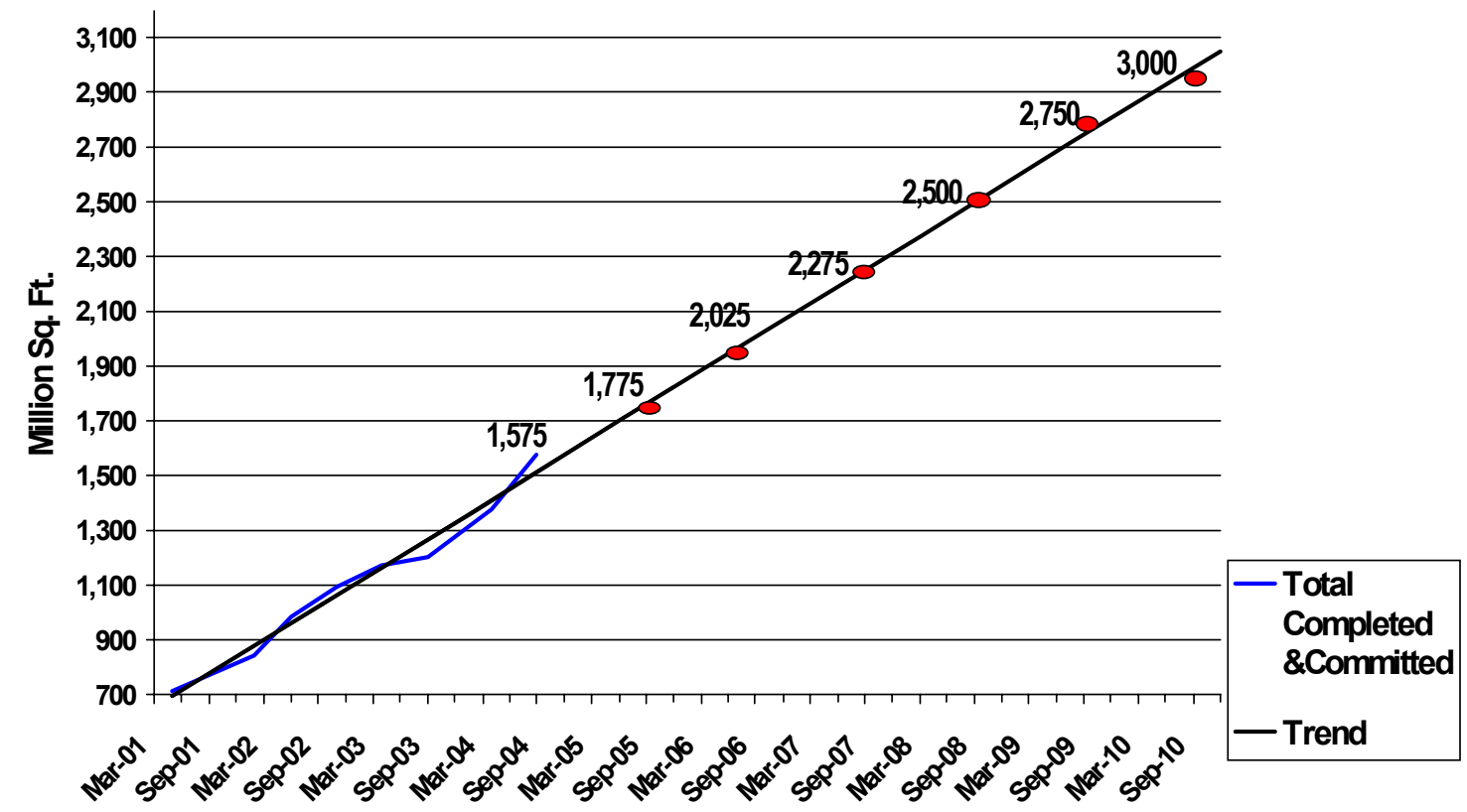

\section{$\underline{\text { Program Results - Structure and Trends }}$}

Recent trends in the data reported to Rebuild America show a small but growing divergence in the relative shares of committed vs. completed square footage. The level of committed square feet has gradually been overtaken by the level of completed square feet and - if recent trends continue - the completed category could exceed the committed category by 200 million square feet by 2010 . This trend is consistent with the expected 
partnership maturity path, as partnerships initiated in earlier years move from the organization and project identification phase to implementation and completion of specific projects.

The Rebuild America square footage numbers are the ultimate result of the formation and operation of individual partnership organizations who identify and support energy efficiency initiatives. Therefore it is not surprising that the strong growth in committed and completed square footage has been mirrored in the growth of partnerships over the same period. Since the program's inception in 1995, the number of partnerships has grown to 699 as of September 2004. In the program's early years, the annual growth in partnership numbers was 35 percent or more. In more recent years, as the partnership base has increased, the annual growth rate has slowed to about 20 percent per year, but working from a larger base -- this rate still represents the addition of about 100 new partnerships per year.

In 2004, for partnerships with committed and/or completed square footage, the average partnership square footage "size" was 4.59 million square feet. However, Rebuild America partnerships vary greatly in size and scope. Some are focused on certain institutions or specific communities, while some other partnerships have a statewide scope. Partnerships also have a normal lifecycle. There is often an interval of several years between establishing a partnership, identifying specific projects (committed square feet), and completing the projects (completed square footage). This correlation between partner "age" and the commitment and completion of specific projects was confirmed in an evaluation of Rebuild America issued in September 2003 by Oak Ridge National Laboratory. $^{2}$

The partnership lifecycle is also reflected in data from 2004 showing that about 49 percent have reported projects to Rebuild America (committed and completed). Of the partnerships who have reported projects, about 35 percent have reported completed project square footage. Approximately 17 percent of all partnerships have completed square feet only, while another 17 percent have only committed square feet. Fifteen percent have both committed and completed projects. In assessing the potential for future projects, this data also shows that 32 percent of total partnerships have some committed square feet.

Depending on their size and objectives, Rebuild partnerships identify and develop one or more specific retrofit projects and the partnerships report this project information to Rebuild. Many partnerships have more than one energy efficiency project, and some partnerships have dozens of individual projects. The size of each project is self-defined by each partnership so consequently there is a wide in the size of individual projects. Based on the latest data and analysis for 2004, within each of the six EERE regions the average size for most projects falls within the $0.4-0.9$ million square feet range. When very large and very small "outlier" projects are removed from the data, with a few exceptions the average project size (committed or completed) falls to 0.5 million square feet or less. The same project data distributed by market sector rather than region shows

\footnotetext{
${ }^{2}$ Ibid.
} 
roughly similar ranges of average project size, with the exception of K-12 schools, which predictably have a smaller average project size of 0.16 million square feet, since each school is usually treated as a separate project.

As part of its efforts to evaluate program results and to effectively target future activities, the Rebuild America program regularly analyzes program activity in each of the six EERE regions and in five market sectors. The six regions are: Southeast, Northeast, MidAtlantic, Midwest, Central, and West (see Figure 2). The five market sectors used by Rebuild America are: Colleges and Universities, Commercial Buildings, K-12 Schools, Local and State Government, and Public and Multifamily Housing. By September 2004 the distribution of committed plus completed square footage was dominated by the West (35.1 percent), the Midwest (24.4 percent), and the Central (18.4 percent) regions. The other three regions had 4-10 percent of the total square footage.

Figure 2

EERE Regions

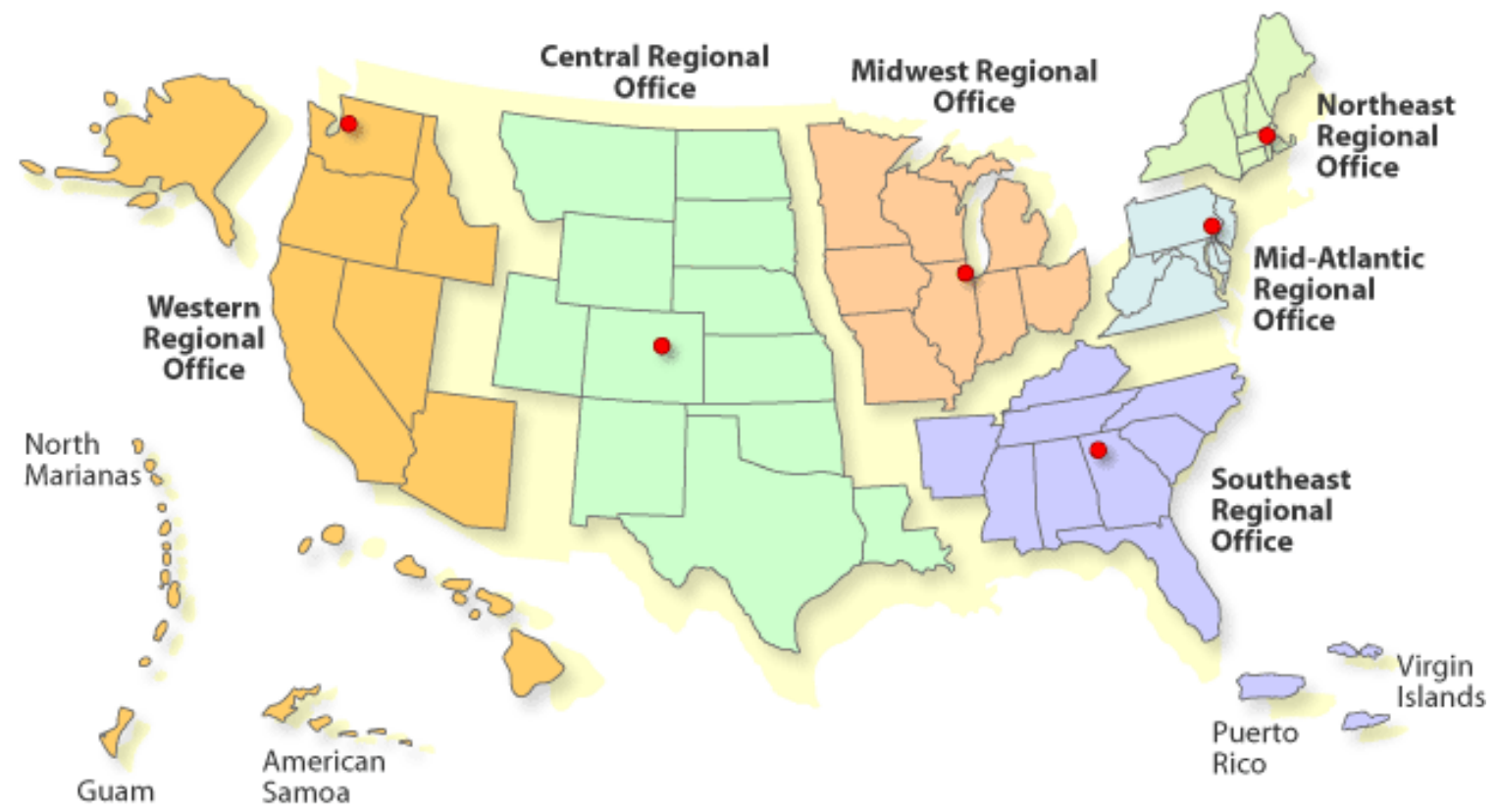

The distribution of square footage by sector is led by K-12 schools (32.3 percent), followed by Local and State Government (23.8 percent) and Commercial Buildings (20.3 percent). Colleges and Universities and Public and Multifamily Housing have 11-12 percent shares. Over the $2002-2004$ period there has been a gradual shift in the relative shares of sectoral square footage. The K-12 Schools and Public and Multifamily Housing have shown stronger growth than the Local and State Government and Colleges and Universities sectors, which in 2002 had total square footage shares of 32.3 percent and 12.5 percent respectively. The Public and Multifamily sector has had the strongest 
growth trend in the last few years, rising from 7.6 percent to 12.2 percent of total square footage in just two years.

Table 2 below summarizes the main program results discussed above. Table 3 presents a more detailed information as of the end date of the contract period of performance $(10 / 31 / 04)$.

Table 2

Summary of Program Results

\begin{tabular}{|l|r|r|r|r|r|}
\hline & \multicolumn{3}{|c|}{$\begin{array}{r}\text { End-Year (FY) Cumulative Results } \\
\text { (million square feet) }\end{array}$} & $\begin{array}{l}\text { Percent } \\
\text { Share }\end{array}$ & $\begin{array}{l}\text { Percent } \\
\text { Share }\end{array}$ \\
\hline & $\mathbf{2 0 0 2}$ & $\mathbf{2 0 0 3}$ & $\mathbf{2 0 0 4}$ & $\mathbf{2 0 0 2}$ & $\mathbf{2 0 0 4}$ \\
\hline Total Program & & & & & \\
\hline Completed Square Feet & 528.2 & 610.0 & 799.9 & 48.3 & 50.8 \\
\hline Committed Square Feet & 565.8 & 594.0 & 775.9 & 51.7 & 49.2 \\
\hline Total & $1,094.0$ & $1,204.0$ & $1,575.8$ & & \\
\hline & & & & & \\
\hline Market Sectors & & & & & \\
\hline Colleges and Universities & 125.6 & 133.4 & 179.6 & 11.5 & 11.4 \\
\hline Commercial Buildings & 239.9 & 287.4 & 319.5 & 21.9 & 20.3 \\
\hline K-12 Schools & 333.8 & 359.5 & 509.6 & 30.5 & 32.3 \\
\hline Local and State Government & 317.9 & 190.8 & 375.2 & 29.1 & 23.8 \\
\hline Public and Multifamily Housing & 76.9 & 54.5 & 191.8 & 7.0 & 12.2 \\
\hline & & & & & \\
\hline Regions & & & & & \\
\hline Central & 82.8 & 193.4 & 290.3 & & 18.4 \\
\hline Mid-Atlantic & 26.9 & 37.9 & 66.1 & & 4.3 \\
\hline Midwest & 120.4 & 264.7 & 385.0 & & 24.4 \\
\hline Northeast & 105.4 & 122.2 & 149.0 & & 9.5 \\
\hline Southeast & 63.7 & 131.9 & 132.9 & & 8.4 \\
\hline Western & 439.1 & 454.0 & 552.3 & & 35.0 \\
\hline
\end{tabular}


Table 3

\section{Rebuild America National Program Results Summary: October 31, 2004}

\begin{tabular}{|c|c|c|c|c|c|}
\hline & $\begin{array}{l}\text { Committed } \\
\text { Square Feet }\end{array}$ & $\begin{array}{l}\text { Completed } \\
\text { Square Feet }\end{array}$ & $\begin{array}{c}\text { Annual Cost } \\
\text { Savings }\end{array}$ & $\begin{array}{c}\text { Annual Energy } \\
\text { Savings } \\
\text { (MMBtu) } \\
\end{array}$ & $\begin{array}{c}\text { Total Energy } \\
\text { Efficiency } \\
\text { Investment } \\
\end{array}$ \\
\hline Results Total & $790,030,137$ & $813,493,811$ & $\$ 392,855,610$ & $85,757,316$ & $\$ 2,171,353,268$ \\
\hline 2010 Strategic Plan Targets & $3,000,000,000$ & $3,000,000,000$ & $\$ 1,000,000,000$ & $64,000,000$ & $\$ 4,000,000,000$ \\
\hline Performance (\% of Target) & $30 \%$ & $27 \%$ & $39 \%$ & $134 \%$ & $54 \%$ \\
\hline Completed Projects & & $813,493,811$ & $\$ 183,960,392$ & $62,186,169$ & $\$ 907,618,151$ \\
\hline Committed Projects & $790,030,137$ & & $\$ 208,895,217$ & $23,571,147$ & $\$ 1,263,735,116$ \\
\hline \multicolumn{6}{|c|}{ Market Sector } \\
\hline Colleges and Universities & $137,461,531$ & $53,066,586$ & $\$ 50,038,643$ & $10,073,403$ & $\$ 386,552,459$ \\
\hline Commercial Buildings & $125,400,296$ & $194,145,240$ & $\$ 62,160,184$ & $7,441,968$ & $\$ 355,412,673$ \\
\hline K-12 Schools & $188,731,059$ & $325,827,421$ & $\$ 102,229,488$ & $53,311,661$ & $\$ 575,756,891$ \\
\hline Local \& State Government & $198,414,314$ & $188,681,702$ & $\$ 124,011,590$ & $11,198,425$ & $\$ 632,388,369$ \\
\hline $\begin{array}{r}\text { Public and Multi-family } \\
\text { Housing }\end{array}$ & $140,022,937$ & $51,772,862$ & $\$ 54,415,704$ & $3,731,859$ & $\$ 221,242,875$ \\
\hline Total & $790,030,137$ & $813,493,811$ & $\$ 420,484,282$ & $85,757,316$ & $\$ 2,171,353,268$ \\
\hline \multicolumn{6}{|c|}{ EERE Regions } \\
\hline Central Region & $235,874,904$ & $55,398,824$ & $\$ 72,833,340$ & $8,253,417$ & $\$ 514,985,339$ \\
\hline Mid-Atlantic Region & $40,129,121$ & $25,965,276$ & $\$ 33,894,055$ & $1,584,750$ & $\$ 117,183,840$ \\
\hline Midwest Region & $102,690,595$ & $294,918,184$ & $\$ 68,033,931$ & $8,798,270$ & $\$ 382,289,895$ \\
\hline Northeast Region & $93,371,555$ & $58,882,648$ & $\$ 48,934,398$ & $3,298,808$ & $\$ 301,918,570$ \\
\hline Southeast Region & $95,909,929$ & $37,035,981$ & $\$ 31,171,012$ & $3,142,845$ & $\$ 183,525,419$ \\
\hline Western Region & $222,054,033$ & $341,292,898$ & $\$ 137,988,864$ & $60,679,227$ & $\$ 671,450,204$ \\
\hline
\end{tabular}




\section{Program Representative Support Activities}

Program representatives are the key element in ensuring that sound relationships are build with community partnerships, and that high-quality services are delivered to them. As determined by the Regional Team Leads, Representatives manage a portfolio of RBA partnerships at various stages of implementation.

Program Representatives are the primary continuing points of contact between individual partnerships and the program. They have overall responsibility for conveying the concept and services of the Rebuild America and for assuring that each partnership attracts a critical mass of local partners and implements a sound Action Plan containing clear goals and a realistic implementation strategy. They aid the partnership in identifying specific assistance needs essential to carry out their implementation strategy, coordinate with RBA staff in the delivery of assistance, and report on the activities and success of the partnership. They also aid in identifying new qualified partnerships.

The Program Representatives also support partnership sustainability. The Representatives also capture, support and encourage peer-to-peer exchanges of information, and ensure accurate measurement and verification to support national metrics. The Representative mobilizes the resources of the program and partners, as dictated by the needs of the partnership, and captures each iteration of the plan to maintain a level of consistency and demonstrate the variety of partnerships for the national program.

The extent of Program Representative consultations with one or more projects is reflected in the summary of Program Representative trips shown in Table 4. 
Table 4

Program Representative Activity Levels

\begin{tabular}{|c|c|c|}
\hline Task & Year & Number of Trips \\
\hline \multicolumn{2}{|c|}{ Task 1 - Partnership and Support } & $\begin{array}{c}\text { Partnership } \\
\text { Support/TA/Regional } \\
\text { Office Support Meetings }\end{array}$ \\
\hline & October 8, 1999 - December 31, 1999 & 37 \\
\hline & January 1,2000 to December 31,2000 & 218 \\
\hline & January 1, 2001 to December 31, 2001 & 294 \\
\hline & January 1, 2002 to December 31, 2002 & 287 \\
\hline & January 1, 2003 to December 31, 2003 & 288 \\
\hline & January 1, 2004 to October 31, 2004 & 208 \\
\hline & Total Task 1 & 1,332 \\
\hline \multicolumn{2}{|c|}{ Task 2 - Program Integration and Assessment } & $\begin{array}{c}\text { Customer Service and } \\
\text { Products and Service } \\
\text { Integration/Strategic and } \\
\text { business Alliances/peer } \\
\text { exchange }\end{array}$ \\
\hline & October 8, 1999 - December 31, 1999 & 13 \\
\hline & January 1,2000 to December 31,2000 & 45 \\
\hline & January 1, 2001 to December 31, 2001 & 94 \\
\hline & January 1, 2002 to December 31, 2002 & 132 \\
\hline & January 1, 2003 to December 31, 2003 & 107 \\
\hline & January 1,2004 to October 31, 2004 & 61 \\
\hline & Total Task 2 & 452 \\
\hline & TOTAL - Tasks $1 \& 2$ & 1,784 \\
\hline
\end{tabular}


Figure 3 depicts the complete process for recruiting, qualifying, and establishing an RBA partnership.

Figure 3

From Prospect to Action

\section{Generate Contacts}

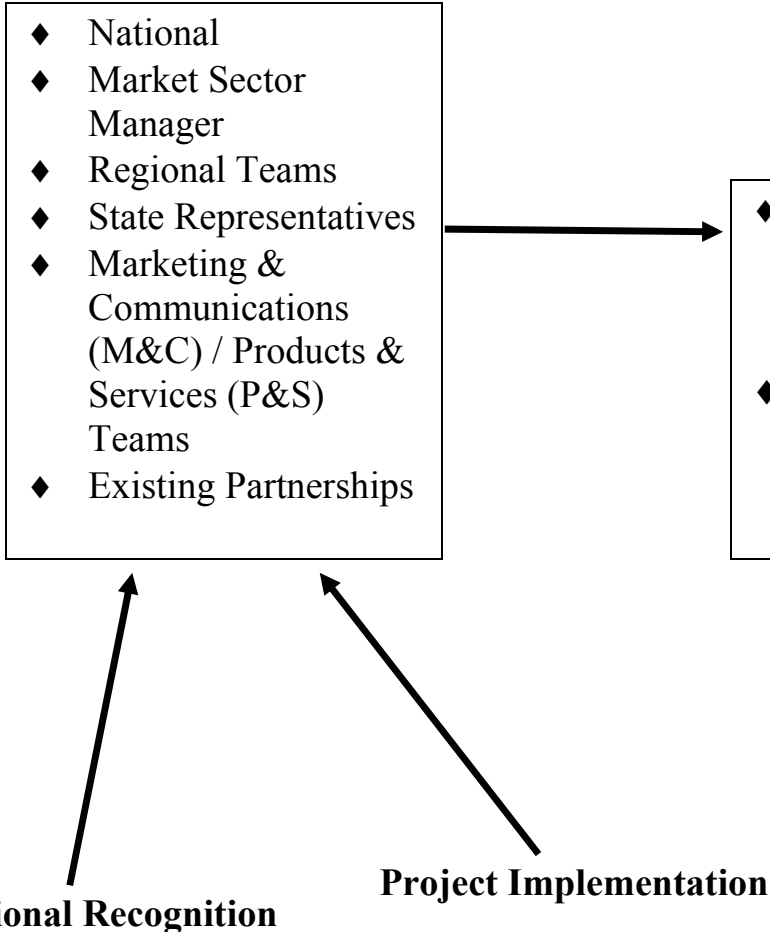

Qualify Leads

( ${ }^{\text {st }}$ Qualifying)

- Regional Team

Leader (RTL)

with lead

generator

- Identify

Champion/

Visionary for

lead

\section{National Recognition}

\section{Project Implementation}

- M \& C Team recognizes Partner/Partnersh ip as milestones are reached
- Partnership takes ownership

- Expand Partnership and Scope Action Plan

- Rep gives assistance as needed/requested

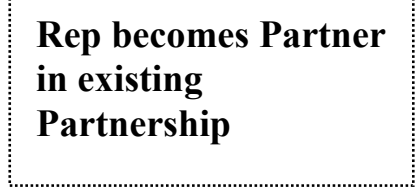

\section{Follow-up ( ${ }^{\text {nd }}$ Qualifying)}

- RTL assigns a Program Representative (Rep)

- RTL determines role of lead generator

- Hold initial meeting

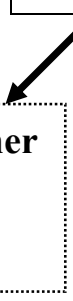

Form Partnership

Partnership Work Begins

- Rep works with partnership to:

$\Rightarrow$ Identify needs/buildings

$\Rightarrow$ Design and complete Action Plan

$\Rightarrow$ Provide Assistance
- Partnership Formation Meeting

- Sign Agreement

- Send Initial materials

$\Rightarrow$ Notebook

$\Rightarrow$ Guides

$\Rightarrow$ Website Password

$\Rightarrow$ Other Materials 


\section{Technical Assistance}

Products are defined as anything tangible or downloadable that Rebuild America has to offer its partnerships, via the program's website, to help them complete their projects. This includes printed or electronic documents, CDs, software, online tools, websites, etc. The purpose of providing these products is to create a simple and streamline approach for making useful information directly available to the partnerships and program staff.

Services may include telephone conversations, presentations, site visits, design reviews, etc. These services are primarily provided by the staff of DOE's National Laboratories. Some types of assistance may also be provided by outside experts or Business and Strategic Partners. This purpose of these services is to help partnerships overcome unique barriers and challenges that cannot be served by available local or state resources.

In order to obtain technical assistance services, designated program staff (DOE regional team leaders, customer service representatives, and state representatives) submit a request via the program website. This request is reviewed and processes by the Assistance Coordinator. Technical assistance that is short duration (less than four hours) or does not require any travel is also provided on an ad hoc basis. This assistance includes basic information requests, phone calls, email communications, and other short-term interactions.

In addition to delivering some technical assistance, as part of its management and coordination role, Aspen was asked to enhance RBA web-enabled activities in this area. In order to meet the need for the program to centrally manage the numerous actions and activities focused on delivering technical assistance, Aspen designed and launching a web-based centralized on-line request and fulfillment process for the customer service representatives to use to access the diverse expertise of the Department of Energy national laboratory system.

During the latest year of contract activity $(9 / 03-9 / 04)$, a total of 110 technical assistance requests were processed. Over 70 percent of these requests came from partnerships in the Local and State Government and K-12 Schools sectors. Over 80 percent of the assistance was provided by staff from DOE National Laboratories, with the remainder coming from Aspen or other contractor staff. About 60 percent of assistance requests covered either requests for information, presentations, or technical reviews. Other types of requests included inspections and technical analysis.

Another innovative website feature developed by Aspen is the Solution Center, a compilation of over 250 of the best technology and system solution resources from the public and private sector. Replacing the old "Rebuild America Toolbox," the Solution Center has the ability to organize the resources by market sector, project process, level of expertise, or a combination thereof, the Solution Center can quickly lead the customer to the specific information they need to meet their unique program or project challenge. Areas of assistance include pre-project planning; project definition; design phase/building 
evaluation; contracts and financing; technology and systems design; construction; building commissioning; and facilities management.

The Solutions Center was created because decision-based tools and strategies are a critical component in any initiative to assist communities and building owners and operators in achieving energy cost savings. The Solution Center created an easy-to-use website that allows users to find technical information in ways best suited to their organizational preference. In addition, this resource maintains an accessible collection of resources on a broad variety of building sector and energy efficiency topics, while guiding users to only those resources that are directly relevant to their purpose or project. These goals were achieved through the creation of a customer-centric information architecture structure that was built on three axes of information: project type, market sector, and level of required technicality.

Aspen is also responsible for fulfilling requests for products that are offered by the program to its target audiences. In the most recent one-year period (9/03-9/04), 1,080 product requests were processes and almost 87,000 items were distributed (including 37,000 copies of Partner Updates). Almost all (90 percent) of product deliveries are made within 24 hours of the initial request. 


\section{Web Site Development and Operation}

During the contract period of performance, Aspen was asked to substantially redesign and augment the program's web-based capabilities. Within 3 months of obtaining the site, Aspen had designed and launched a new website with an array of new functionality and features. In addition, the site was organized based on the market sectors of the target audiences for the program, rather than internally focused information architecture.

As of October 2004, the website encompasses over 3,500 dynamically generated pages and receives over 1.3 million hits, 62,000 visitors, and 272,000 page views per month.

The RBA website now includes the following main capabilities:

- Strong online, real time data collection and reporting capability using a secure user authenticated process that provides email feedback of submission to project and DOE staff, and a review process where the user can modify initial input and compare against industry sector benchmarks for the key metric data. Local community partners have submitted 1,800 projects record using this voluntary data collection system. There are 10 dynamic reports that aggregate this key metric data by market sector, region, state, project status, and date range.

- A series of internal management and communication tools were developed to provide programmatic information for DOE headquarters and regional staff, including electronic procedures called the Program Team Manual for operations issues, planning and task schedule sharing tools using Microsoft Excel and Project files. Help system files in Adobe .PDF and web formats were created to train and assist users in handling information effectively.

- A substantial database of project case studies highlighting Rebuild America energy efficiency projects. Over 50 success stories are available in both web and print formats, and are filtered by market sector. There is a web workflow component that allows community partners to submit success story data to the marketing and communications team for review, processing, posting and approval.

- Online Solution Center to provide industry-based information products and targeted technical information for decision makers, including over 750 information products. This information is selected based on a buildings industry-based information architecture that resonates with the target user groups. The information sources are chosen based on criteria that match program objectives, and includes the best information that is readily available about energy efficiency building topics. Meta data (source, point of contact, level of technical complexity, format, topical description, date) about each information product is displayed on the web site, thereby allowing a user to determine if product matches his requirement.

- Web-based integrated system for processing building technical assistance requests, tracking technical assistance activities, and providing customer feedback mechanisms 
for the Rebuild America program.. This system was developed in 2002 to give DOE headquarters staff, regional offices, state and local energy officials access to the building energy experts in both the public and private sector who could best fulfill the assistance requirement. Standardized workflow protocols were developed and automated so both the requestor, provider, and program team could oversee the status and impact of customized energy technical assistance. Results and reports of the technical assistance are captured in this system, along with customer feedback for quality assurance of delivery purposes. Over 350 large formal program technical assistance requests were received and processed during the contract.

- Created a user centric web-based online store system for dissemination of hard copy booklet, CD, and print information products. This system is integrated using the sophisticated Lawson Enterprise Resource Planning System to provide product order fulfillment and inventory management capabilities. Over 220,000 items have been distributed for the program during this contract using this distribution system.

- Online professional development and training curriculum was developed for new and experienced Rebuild America program representatives, who could request these workshops on the web site, and review the status of the requests electronically. The three workshop curriculums were

- All About Rebuild America - This workshop covers how the Rebuild program works, the help that was available for projects and promotions, and when and when to tap that help to get maximum results.

- Recruiting Energy Efficiency Partners - In this highly interactive workshop, participants explore the seven habits of effective marketing and how they apply to recruiting Rebuild America partners. Using real-world examples, attendees learn how to choose target audiences, research and identify good opportunities, select the most effective marketing techniques for a given situation, and, ultimately, how to secure motivated and active partners.

- Using the Rebuild America Website - Through demonstration and discussion, the workshop teaches participants how to use the website to get help with projects, form partnerships, and enhance the partnership's visibility. Participants also learn how to report metrics and partnership successes and get tips for navigating the site.

- Customized web news and event content management system was created for use by DOE staff and program representatives to submit program energy events and news electronically. A review and approval workflow was established, and weekly news articles are added, categorized, and disseminated in various sections of the web site. Over 2,200 news stories and 2,000 events are displayed on web site.

- A Rebuild community partnership data template was created to identify, communicate, support, and leverage resources of over 1,000 organizations and 5,000 contacts. This component of the web site allows program representatives to track the 
activities, successes and shared experiences of the Rebuild America community partnerships, and provides valuable peer exchanges among building sectors and regions. Public and private companies, non profits organizations, and state and local government agencies all are a part of this web based Rebuild America Network.

- Information dissemination capability for program participants to download project data into standard templates for decision makers.

- Created and integrated several state-specific websites and databases. The Texas Energy Partnership web site was developed in 2002 to support the Texas State Energy Conservation Office in complying with state statutes for energy efficiency. The web site created a communications and marketing approach and outreach vehicle for the State Energy Office, and provided energy information in seven technical areas. It also provided a data compliance reporting system to assist the State Energy Office in monitoring program results. The North Carolina Utility Savings Initiative was another state based web site and database developed in 2003 to allow the State Energy Office an option to process energy audit reports for over 12,000 state buildings. It created an opportunity calculator to assist decision makers in financing options that had the greatest energy savings potential. Further, it created a dynamic reporting tool to assist energy engineers in collecting, processing and evaluating program energy audit outreach.

- Trained information technology professionals who monitor system operation and performance hosted the web site in a secure information network operations center. The site had a $99.99 \%$ availability uptime, and was moved from a single server to a dual server, then to a web cluster server system to provide better operational capacity, performance and security. The Web Server used Microsoft's Information Index Server version 4 and 5 on the front end, and Microsoft's SQL Server 2000 database on the back end. 


\section{Business and Strategic Partners}

As part of the program's strategy to promote sustainability and leverage program resources by tapping other private/public expertise, Aspen was asked to augment and rationalize the program's relationships with outside organizations.

Business Partners: The Business Partner component of Rebuild America was initiated as a means to formally connect private sector providers of buildings related products and services to the program and its partnerships, and to expand the market for energy efficiency. The goals of the Business Partner portion of Rebuild America are: 1) Provide additional project-related technical and educational resources to the community projects; and 2) Help create value-added relationships between the industry's products and services providers and the community projects.

Business allies range from small local businesses that serve specific community partnerships to national corporations that have various offices and representatives to serve projects throughout the United States. They offer assistance in achieving building efficiency and promoting community growth through efficient products and/or services. Business allies also participate in broader events including Rebuild America's bi-annual national conference, business partner meetings, and regional and technology-specific workshops. For example, business allies participate in Technology Seminars for RBA participants; as of September 2004, over 90 seminars have been conducted, with over 4,000 participants.

During the course of Aspen's management of this activity, the number of Business Partners has grown from 10 to 175. The RBA-Business Partner relationship has also been reorganized to better incentivize Partners to become and remain active contributors to the program.

Strategic Partners: Rebuild America also teams with national associations and organizations to help promote energy efficiency to their memberships and to better understand the energy issues that these groups face. These strategic allies currently serve audiences in colleges and universities, state energy offices, energy service companies, housing officials, and state legislatures. Through combined communications and service programs, Rebuild America and its strategic allies are able to develop and deliver useful resources to participating projects.

During Aspen's management of this program, the number of strategic allies has grown from 4 to 24 organizations. 


\section{Training/Workshop Activities}

Program Team training is an important component of the overall program implementation strategy. Understanding the various program elements is crucial to developing and implementing program objectives that take full advantage of the wide array of program resources available to participants. One key factor in developing a strategy is in understanding the variety of program implementation strategies from state to state and region to region and developing a training and workshop strategy to meet them where they are instead of where the program wanted them to be. In other words, have a multi-pronged approach that identifies the unique characteristics of individual program participants while ensuring continuity of program objectives. Therefore the training approach centered around three main objectives:

1) Identifying and sharing lessons learned through peer exchange

2) Providing individual State Energy Offices with integration planning

3) Providing specific training for individuals and/or groups of program participants on the available RBA resources and tools

In 1999 Aspen developed and implemented the Peer Exchange initiative that brought together partnerships to share their experiences in overcoming barriers to implementing energy efficiency projects. From 1999 to 2004, thirty-one regional peer exchange workshops were conducted nationwide (table 5). These workshops were conducted in each of the six DOE regions. These peer exchange workshops were designed to meet the specific challenges that program participants in a particular region faced. They were focused on specific areas of improvement, such as growing and energizing regional programs, solving problems and providing assistance, increasing the breadth and success of partnerships, growing the regional networks, and disseminating information. Real life examples were discussed with workshop participants identifying possible solutions to overcome the identified barriers. Through these Peer Forums, Rebuild America is providing support for Rebuild America partners to serve as a resource to help other Rebuild America partners overcome challenges and develop successful Rebuild America partnerships and projects.

In 1999 Aspen also implemented program representative training workshops. From 1999 to 2004 there were thirty-one (31) program representative workshops, which were held in coordination and conjunction with the Peer Exchange workshops (table 5). These workshops were designed to assist State and Regional Program Representatives in understanding, identify and accessing program resources.

Aspen also developed and delivered Program implementation and integration planning workshops to specific states upon request. These workshops were facilitated planning sessions designed to assist State Energy Offices (SEO) in integrating Rebuild America as a "gateway" program for a wide array of deployment and technology transfer initiatives within the SEO. 
In 2002 Aspen developed and implemented the Professional Development Series, which provided web training modules for program participants in three basic program knowledge categories. The focus of this series was creating standardized information and tools training that could be requested on-line and implemented by knowledgeable trainers. Individual trainers were required to complete a train the trainer course to ensure continuity in message and module delivery. The modules are customizable to specific local and region situations but provided an overall consistent delivery of program information. The Professional Development Series modules included All About Rebuild America, Using the Rebuild America Website, and Recruiting Energy Efficiency Partners

Table 5

Key Program Training Activities

\begin{tabular}{|l|r|r|r|r|r|r|}
\hline Activity & $\mathbf{1 9 9 9}$ & $\mathbf{2 0 0 0}$ & $\mathbf{2 0 0 1}$ & $\mathbf{2 0 0 2}$ & $\mathbf{2 0 0 3}$ & $\mathbf{2 0 0 4}$ \\
\hline Peer Exchange & 5 & 6 & 5 & 5 & 5 & 5 \\
\hline Program Representative Training & 6 & 2 & 5 & 6 & 6 & 6 \\
\hline
\end{tabular}




\section{Conclusions and Recommendations}

1a. Observation: The customer service model of building long-term relationships between partnership staff and RBA program representatives has been validated by independent evaluations, ${ }^{3}$ partnership feedback, and program results.

1b. Recommendation: The current RBA customer service model should continue to be the primary deployment strategy for the program.

2a. Observation: Regular monitoring of partnership progress allows program representatives to provide targeted decision-based information at key "tipping points" in the project development process, which greatly enhances the prospects for project success.

2b. Recommendation: Partnerships should continue to have long-term access to technical information from trusted sources that is selected to meet their specific requirements. The program should continue to interact with customers where they are rather than where the program thinks they should be.

3a. Observation: Valuable performance data can be collected from participants in a voluntary program if data entry is made simple and convenient, and if the data is converted into information that the participants can use to validate and support their own efforts.

3b. Recommendation: Web-enabled tools should continue to be used to collect performance information from participants and participants should be given easy access to the data that is collected.

4a. Observation: Program success requires the integration of the customer service deployment model with access to a wide range of information products and technical services.

4b. Recommendation: The integrated use of the customer service model and product/service technical support should be continued.

5a. Observation: The program does not currently generate meaningful data on Business or Strategic Partner activities.

5b. Recommendation: Develop processes and tools to collect and report relevant information on Business and Strategic Partner activities.

${ }^{3}$ Ibid. 
6a. Observation: Initiatives that targeted specific market sectors; e.g. K-12 schools, yielded substantial growth in program participation.

6b. Recommendation: Additional sector-specific initiatives should be implemented.

7a. Observation: The data on the deployment of technical assistance is currently insufficient to allow useful monitoring and evaluation. The information that is available is not collected using a common protocol.

7b, Recommendation: A common format and procedure for collecting technical assistance deployment information should be developed and applied to all technical assistance efforts.

8a. Observation: The RBA deployment model is a multi-component strategy that integrates customer service, information products and distribution, technical assistance, communications, regional/state involvement, and data collection and reporting. In order to achieve maximum program effectiveness and synergy, each of the components should be operating at similar levels of capability and service provision.

8b. Recommendation: All components of the program must fully augment their activities and capabilities to more closely match the activity levels of the other components. 


\section{References}

Task Order No. DE-AD26-99FT40235 between Aspen Systems Corporation and the National Energy Technology Laboratory

Rebuild America Strategic Plan 2001-2010

Action Plan Check-List

Rebuild America Program Manual

Rebuild America 2004: Program Accomplishments and Analysis

Rebuild America: 2004 Operational Plan and Deliverables Matrix

Regional Rebuild America Marketing and Customer Service Plan for 2000

The Rebuild America website: http://www.rebuild.org 


\begin{abstract}
Appendices
The following four appendices contain documents that provide examples of the management, planning, and evaluation outputs of the Rebuild America program during the contract performance period. Appendix A is a checklist used by Program Representatives to assist new partnerships in organizing and in developing specific plans and goals. Appendix B is the program's standardized procedures manual. Appendix C is the most recent annual data analysis of RBA performance metrics. Appendix D is the most recent annual planning document for the program, and Appendix E is an example of a detailed regional marketing plan from one of the program's most successful regional activities.

Appendix A: Action Plan Check-List

Appendix B: Rebuild America Program Manual

Appendix C: Rebuild America 2004: Program Accomplishments and Analysis

Appendix D: Rebuild America 2004: Operational Plan and Deliverables Matrix

Appendix E: Regional Rebuild America Marketing and Customer Service Plan for 2000
\end{abstract}

The Rebuild America website can be reviewed at http://www.rebuild.org 


\section{APPENDIX A}

Action Plan Check-List 


\section{ACTION PLAN Check-List}

\section{PARTNERSHIP NAME:}

\section{PROGRAM REPRESENTATIVE:}

\section{DOE REGION:}

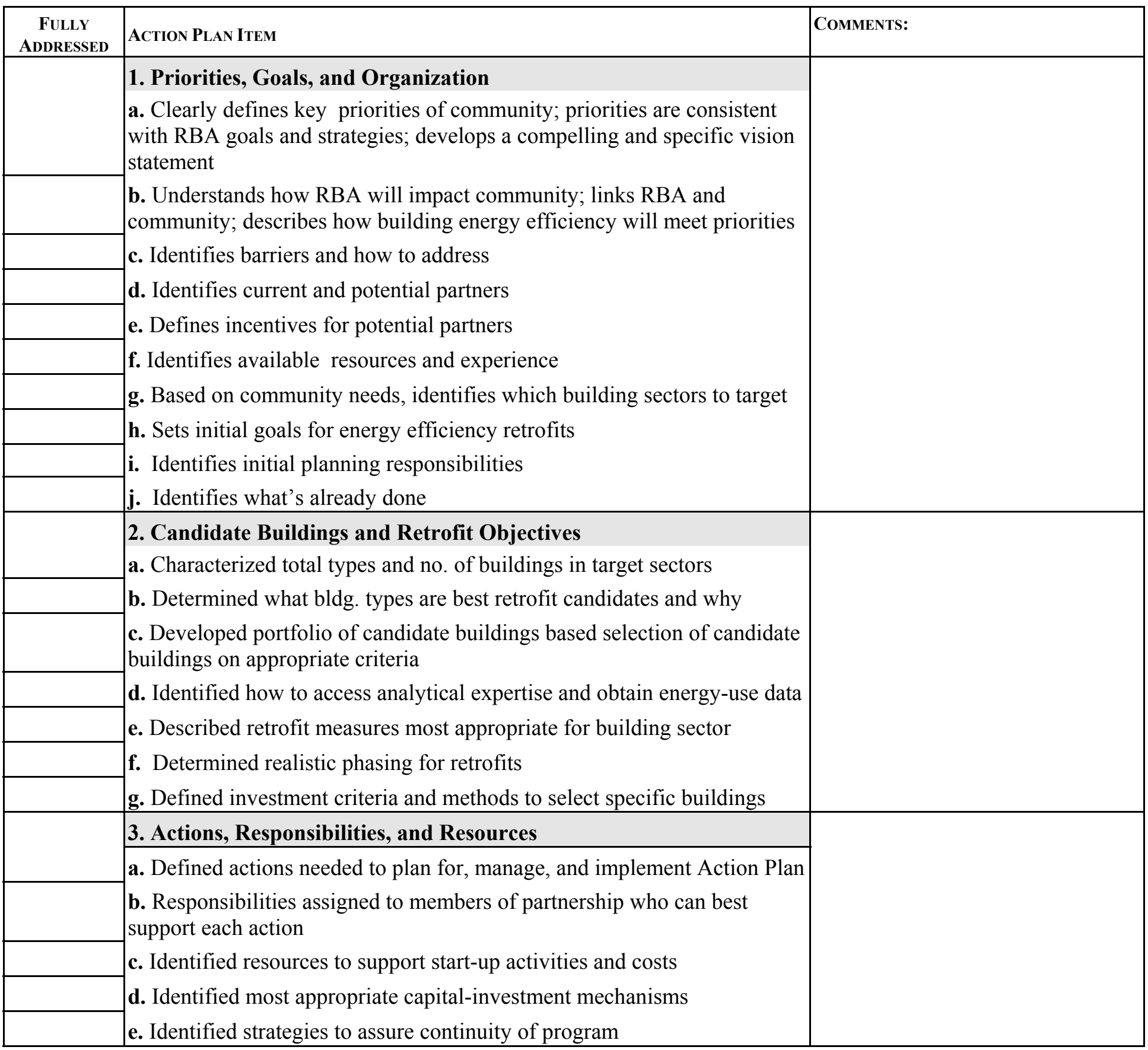

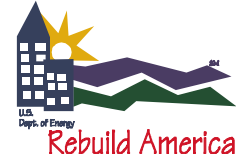




\section{ACTION PLAN Check-List}

\begin{tabular}{|l|l|l|}
\hline $\begin{array}{c}\text { Fully } \\
\text { AdDRESSED }\end{array}$ & ACtion Plan Item & CoMmeNTs: \\
\hline & $\begin{array}{l}\text { 4. } \text { Monitoring, Evaluation, and Reporting } \\
\text { a. } \text { Defined information most important in measuring and reporting } \\
\text { progress } \\
\text { b. } \text { Defined methods for monitoring pre- and post-retrofit } \\
\text { c. } \text { Identified sources of data post-retrofit performance } \\
\text { d. } \text { Identified technical staff skills, responsibilities and equipment required }\end{array}$ & \\
\hline $\begin{array}{l}\text { e. } \text { Determined what kind of reporting needed, what reporting schedule to } \\
\text { follow, and who is responsible }\end{array}$ & \\
\hline & $\begin{array}{l}\text { 5. } \text { Promotion and Expansion } \\
\text { a. } \text { Established clear objectives, methods, and actions desired through } \\
\text { promotional actions } \\
\text { b. } \text { Developed strategy for education, training, and recognition } \\
\text { c. } \text { Identified individuals in community who will be champions } \\
\text { d. } \text { Identified community vehicles for promotion and expansion } \\
\text { e. } \text { Developed objectives for long-term expansion } \\
\text { f. } \text { Linked market approach to all other actions }\end{array}$ & \\
\hline
\end{tabular}

\section{Inclusion of Rebuild America Program Goals in Action Plan}

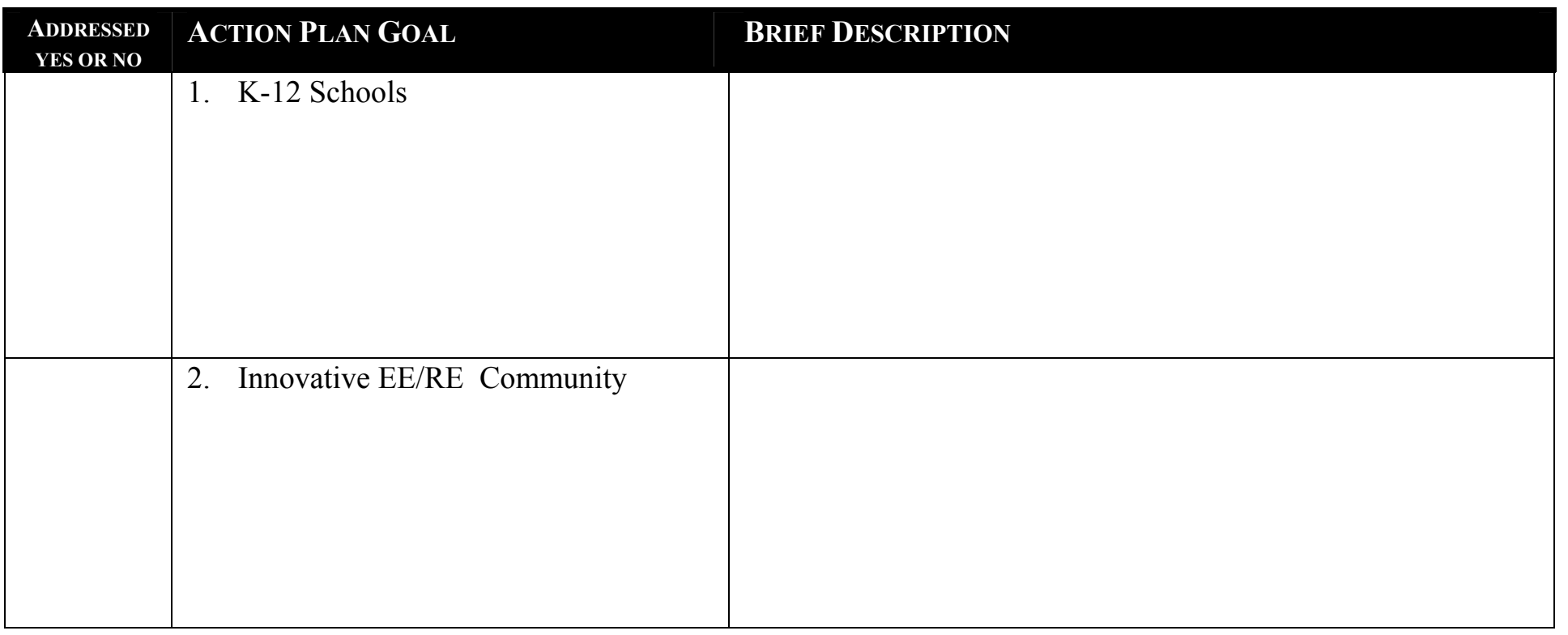




\section{APPENDIX B}

Rebuild America Program Manual 


\section{Rebuild America Program Manual}

\section{Table of Contents}

\subsection{Formation}

1.1 Prospective Partnerships ......................................... 1-1

1.1.1 Prospect Inquiries ....................................... 1-1

1.2 Partnership Formation.............................................. $\quad 1-2$

1.3 Partnership Commitment ........................................

\subsection{Planning}

$2.1 \quad$ Action Plan Development......................................... 2-1

2.1.1 Submission ............................................. $2-2$

2.1.2 Partner Agreement...................................... 2 2-3

\subsection{Action}

3.1 Project Process .......................................................... 3-1

3.2 Partnership Progress ..............................................

3.3 Resources ........................................................

3.3.1 Local Resources ....................................... $3-5$

3.3.2 Rebuild Network........................................... 3-7

3.3.3 EERE Clearinghouse …………………….... $3-9$

3.3.3.1 Technical Assistance ........................ 3-9

3.3.4 Contributing Resources............................................ $\quad 3-10$ 


\subsection{Program and Partnership Promotion}

4.1 Overview and Rationale ............................................. 4 4-1

4.2 Communications and Partnership Promotion .............. 4. 4-2

4.3 Marketing and Communications................................. 4- 4-6

4.4 Business Partner Support .......................................... 4.. 4-9

4.5 Strategic Partner Support....................................... $\quad 4-12$

4.6 Partnership Orientation and Recognition .................. 4- 4-14

\subsection{Expansion and Sustainability}

5.1 Adding new partners ........................................... $\quad 5-1$

\subsection{Strategic Partners}

6.1 Strategic Partners Structure ...................................... 6-1

6.2 Strategic Partners by Sector ...................................... 6-1

\subsection{Products \& Services}

7.1 Products \& Services Structure

$7-1$

\subsection{Business Partners}

8.1 Business Partner Overview

$8-1$

\section{Appendix A - Rebuild America Administration}

A Program Roles and Responsibilities

A-1

\section{Appendix B - Resources}

B.1 Forms

B.2 Glossary of Terms
B-1

B-15 


\section{Section 1.0 Formation}

\section{Section 1.1 Prospective Partnerships}

\section{Description:}

Marketing leads, or prospective partnerships, for Rebuild America are generated in several ways. Interested parties can call or email the Rebuild America Clearinghouse through contact information found in Rebuild America's marketing pamphlets or information packets. Prospective partnerships also inquire about the program through the public website. Program Representatives and other Program Team members generate lists of prospective partners at industry meetings, conferences, and workshops, as well as during community presentations. Prospective partnerships also may contact Program Representatives based on referral from another community partnership member.

\section{State Involvement/Notification Protocol}

The existing Rebuild model is designed with the State Representative being the primary point of contact in their state. Although programs function differently depending on where the Rebuild Program is based in the state structure, a general process model follows:

1. If the State indicates they are the lead then all contacts are directly referred to the State.

2. If a State has asked Rebuild to be the lead/representative and we receive a contact inquiry we notify the State and proceed to work with the contact and inform the state of the progress.

However, as with all things someone may call and want for whatever reason to visit with the National Rebuild folks. If that happens, the State is notified and the request is satisfied in coordination with the state.

How prospects are handled by the Clearinghouse, the Marketing \& Communications (M\&C) team, and Team Leaders is discussed in the following section.

\section{Section 1.1.1 Prospect Inquiries}

\section{Description:}

The process under which interested communities, through calling the Rebuild America Clearinghouse, accessing the Rebuild website, referral or direct contact, become prospective partnerships to the Rebuild America program. 


\section{Purpose:}

To ensure a process is in place to handle Rebuild America program prospective partnership inquiries in a timely and efficient manner.

\section{Process:}

1. A prospect calls the Clearinghouse, run by Washington State University, contacts via the website or is referred to the Clearinghouse from another source, inquiring about Rebuild America.

2. The Clearinghouse will gather the prospect's contact information, provide any requested information, and provide a generic cover letter acknowledging the call.

3. The Clearinghouse will then send an e-mail message containing the prospect's contact information and any other useful information about the prospect to the responsible Team Leader and State Representative (see \#2 below under Other Inquiries).

4. The Team Leader will follow-up with the State Program Representative with regard to the contact/prospect and explore resources and approach in qualifying the contact as a Rebuild America Program participant.

Other Inquiries:

From time to time inquires come directly to a member of the Program Team. These contacts can come as a result of participation in a workshop, conference or meeting or as simply as talking with someone who expresses an interest in Rebuild while waiting for a flight in an airport. In any event, when an inquiry is made directly to a member of the Program Team:

1. An email message containing the prospects contact information and any other useful information about the prospect should be sent to the Team Leader of the applicable region.

2. Once the Team Leader receives the contact information they will forward it to the State Program Representative. The Team Leader can and should discuss with the Program Representative (state) any support they might need to qualify that contact. (note: refer to 1.11 "State Notification Protocol").

\section{Section 1.2 Partnership Formation}

\section{Description:}

Effective Date: January 2004

Partnership formation is the creation and initial development of a Rebuild Partnership. The intent is to involve enough community leaders so the partnership becomes both a "functioning entity" and one with community 


\section{Rebuild America Program Manual}

wide "influence." Any organization can lead a partnership, but the partnership must include at least one public and one private partner. The right mix of partners is essential. Partnerships are not rigid entities and will contain different partners at different stages of activity. Formation should focus on getting participation and commitments from key leaders of local government, schools, community based organizations, other public entities, and private industry and on identifying energy efficiency projects for immediate impact.

\section{Purpose:}

Formation is the foundation for a partnership and its purpose is to assure that Rebuild partnerships are as "deep and wide" in a community from the start as possible. This will help them get enough buildings improved so that their community takes notice. The partnership should contain or have access to the resources necessary to define and successfully carry out their action plan. The goal it to foster self-sufficient, action-oriented partnerships that can institutionalize in their community to one where optimizing a building's performance, through energy efficiency and renewable energy technologies, products and practices, becomes "business as usual."

\section{Process:}

The Program Representative is responsible for assisting the prospective partnership in defining and recruiting partners. Forming a partnership will be a very individualized effort for each partnership, depending on their goals and objectives.

The Program Representative that is attempting to help a community form a viable and dynamic partnership should keep these three milestones in mind:

1. Work with the lead organization to set up a Partnership Formation meeting. A Partnership Formation meeting allows identified community leaders learn of the program and of the "initial community vision" as presented by the champion. If the right mix of folks and presentation happens, it will inspire participation and action by a large percentage of attendees. At this meeting the Program Representative will provide an overview of the Rebuild America program and the lead organization (champion) will present their vision for the community and how Rebuild can help. The meetings also frequently include an additional speaker who speaks to the community's "hot topics." The meeting should conclude with a call to action, in which attendees are encouraged to become part of the partnership and set a date for the first partnership meeting.

2. The first meeting is used to begin developing the Action Plan, which is covered in Section 2.1. The Program Representative must work with the lead organization and those other community members that have been identified as critical to the process of identifying and articulating their community's vision (i.e. What are their community's needs? How can Rebuild help address those needs? What needs to be accomplished, by whom? Etc.) These are the initial elements for their Action Plan.

3. Program Representatives should continue to work with the partnership in subsequent meetings. As needs are identified, it is important to help the partnership determine who in the community 
should be invited to join the partnership to fill that need. Also as many partnerships move forward with their Action Plans, additional partners will come forward to become part of the synergy. Once the action plan has begun, the Program Representative must assure that all necessary resources are made available or at least identified for the partnership. The Program Representative must help keep the process moving along, the goal is to quickly get an initial project completed which will help in keeping momentum high. Nothing succeeds like success!

\section{Section 1.3 Partnership Commitment}

\section{Description:}

Effective Date: January 2004

The process under which a prospect makes a commitment to join the Rebuild America program after forming a community partnership.

\section{Purpose:}

When the newly formed community partnership and their Program Representative are ready, the partnership will join Rebuild America by completing and submitting the Partnership Agreement on the Rebuild America website. The partnership will then be entitled to use the Rebuild America logo and offered additional products and services under the Rebuild America program. The partnership will be recognized for joining the program with a welcome certificate, often given out in conjunction with some form of ceremony.

Note: The Rebuild America Partnership Agreement form should never be used as marketing handouts.

\section{Process:}

1. After meeting with the prospective partnership and after the Program Representative and Team Leader agree that the newly formed community partnership is ready, the Program Representative will complete Rebuild America Partnership Agreement on the Rebuild America website and will submit the completed application, including the planning questions.

Note: the Program Representative will need to gather and include all required information before the application will be accepted by the outline processing tenure.

2. Ensure all planning questions were addressed and the application was complete. The Program Representative can print a copy for formal signing. The form can not be submitted with out required information included.

Once this occurs, the community partnership is then officially referred to as a Rebuild America Partnership. 


\section{Rebuild America Program Manual}

3. The assigned Program Representative will then ensure, from that time forward, that the partnership information on the Rebuild Network is updated and complete.

4. The Webmaster will send an email to the new partnership contacts with their Rebuild Network usernames and passwords.

5. The M\&C team will send a generic cover letter welcoming the partnership to the program on behalf of the National Program Manager. A welcome certificate is sent to the new partnership unless the Program Representative asks to receive the certificate instead to hand to the partnership at a special event.

6. The partnership will also receive a new Partnership Welcome Kit and two copies of each program Technical Guide, unless the Program Representative asks that these materials be held back until such time as the partnership either requests them or needs them.

7. The partnership will also be recognized as a newly joined member on the public web site, in the program's bimonthly newsletter, in DOE's weekly report, and the program's monthly Flash Report. 


\section{Section 2.0 Planning}

\section{Section 2.1 Action Plan Development}

\section{Description:}

The Action Plan is a partnership's business plan. A complete Action Plan will outline defined goals and objectives as well as an implementation strategy to achieve those goals. The Action Plan should be a living document, one that is modified and expanded periodically as the composition and focus of the partnership changes.

Since goals, needs, and resources will differ significantly from community to community, individual action plans will vary in their scope and sophistication. However, every action plan should contain the five essential elements as articulated in detail in the Action Plan Guide and listed below:

$\begin{array}{ll}- & \text { Priorities, Goals, and Organization } \\ - & \text { Candidate Buildings and Retrofit Objectives } \\ - & \text { Actions, Responsibilities, and Resources } \\ - & \text { Monitoring, Evaluation, and Reporting } \\ - & \quad \text { Promotion and Expansion }\end{array}$

\section{Purpose:}

The Action Plan serves as a roadmap to success by defining the partnership's vision, goals, structure, objectives, responsibilities, resources, etc. and when followed helps in leading to a successful Rebuild community based partnership with real results.

Taken as a whole, the action plan development process assures that the plan will define what the partnership wants to achieve, when to expect those achievements and who will be responsible for realizing them.

By setting clear goals and a solid management structure for the partnership, the Action Plan will help to:

- $\quad$ gain essential local policy and financial support

- $\quad$ market and expand the program on a community-wide basis

- $\quad$ obtain buy-in from other partners as the partnership grows

- $\quad$ achieve and verify benefits for the community.

A completed Action Plan is also a prerequisite for obtaining customized technical assistance from DOE and its national laboratories. 


\section{Process:}

The Program Representative is responsible for emphasizing the importance of complete and comprehensive Action Plan as part of the development of a new partnership. As stated in Section 1.3, the Partnership Agreement form can be utilized as the first step in developing a partnership's Action Plan. There are eight partnership-planning questions contained in the Partnership Agreement. By addressing these questions at the time of formation and commitment, the partnership has a foundation with which to build the rest of their Action Plan.

The roads to a completed Action Plan are very different. The Program Representative must be engaged in its development but it is the partnership's job to complete the plan and submit it to Rebuild.

There are many Action Plans available on the Rebuild Network that can be used by the partnership as examples or guides when developing their plan. They include histories and summaries of the partnership as well as contact information.

The initial Action Plan should be endorsed by all members of the partnership and, when possible, formally adopted each partner's management or policy-making bodies, like the city councils or school boards. An "Example Partner Agreement" is included in Appendix A.1 to provide one method of formally obtaining these commitments.

The Program Representative is responsible for obtaining a copy of the partnership's completed action plan and submitting it to the Clearinghouse (see Section 2.1.1).

A good Action Plan means little unless it is acted upon in a timely manner. Enthusiasm fades quickly without real world successes. Program Representatives must help partnerships get a Rebuild "pilot" building project begun, even if their Action Plan is not fully completed. Building additions or remodeling projects that are already approved, are wonderful opportunities for early successes.

Members of Customer Services, Team Leaders, peers and others are available to assist you with this fundamental element to successful partnerships --- use them!

\section{Section 2.1.1 Submission}

\section{Description:}

The process where partnership's Action Plans are submitted, summarized, and posted on the Rebuild Network. 


\section{Purpose:}

The purpose for this activity is to capture all partnership action plans and store them in an easily accessed, useful location for partnership use, peer exchange and to give Rebuild America a better picture of the types, focus, density, etc., of our partnership's in order to better focus limited resources.

\section{Process:}

1. Initial Action Plan delivered by Lead Partner to Program Representative (in electronic form if possible).

2. The Program Representative completes the necessary portions of the Partnership Summary Sheet. The Program Representative then sends both the Action Plan (in electronic form) and the Summary Sheet to the Clearinghouse.

3. The Clearinghouse logs the Action Plan and forwards it to the Customer Service Contact and M\&C for processing with cc to the appropriate Regional Team Lead.

4. Customer Service will upload the Action Plan and the Partnership Summary Sheet to the Rebuild Network. M\&C will then send a letter of congratulations and certificate of Action Partner status to the Partnership Lead under National Program Manager's signature.

\section{Section 2.1.2 Partner Agreement}

\section{Description:}

The addition of partners to a partnership is essential to its longevity and evolution. Partners can add valuable technical and interpersonal expertise as well as an influential network of organizations and individuals that effectively solidify a partnership's viability within a community. This is an example format for a Partner Agreement, which should be modified at the discretion of the partnership. The Partner Agreement is a tool for the partnership to use in solidifying relationships with partnering organizations and individuals within a community. It is NOT intended as a document that would be sent to the Clearinghouse, Marketing \& Communications (M\&C), etc. Partners can be directly added to the partnership via the Rebuild America website by the partnership contact.

\section{Purpose:}

The lead partner (executive/steering committee) should take responsibility for expanding the efforts of the partnership. The example Partner Agreement (see Appendix B.1) is one tool that the Program Representative can use to aid in this effort. The Partner Agreement can be used as an aid in marketing for prospective/desired partners to the partnership. In addition, the voluntary agreement adds a measure of accountability to the partner as a contributing member of the partnership. 


\section{Process:}

Help the partnership to identify key individuals and organizations within the community that would serve or be well served by joining the partnership.

The Program Representative should encourage the Partnership's leadership to modify the example Partner Agreement so that it fits in with the goals of the partnership.

The partnership may want to have several different Partner Agreements to target specific sectors within a community. Some partners may wish to have more extensive agreements, especially with those building owners that they commit significant resources to help. For example, an "Interdepartmental Partner Agreement" might be used to target specific divisions within city management. The City of Philadelphia incorporated this approach into their action plan (see the City of Philadelphia Action Plan on the Rebuild Website for more information). Another example may be for allies, bankers, building owners, ESCOs, etc.

The Program Representative should also encourage the partnership to utilize the Rebuild Network in capturing information about and recognizing their partners. 


\section{Section 3.0 Action}

\section{Section 3.1 Project Process}

\section{Description:}

Effective Date: January 2004

To upgrade buildings and facilities, building owners and facility managers need to move from an idea to results. This summary outlines a project development process for facility managers. It emphasizes the need to get top-level management approval before investing in extensive planning and analytical efforts. It considers the exploration and acquisition of technical services and financing as an integral part of the process.

\section{Summary of the Process}

Decide to Act -- Set your project's overall scope and approach, and get management approval

1. Decide What Building Improvements are Important

a) Are there well known improvements that are clearly needed in your buildings?

b) Are there upgrades that will help your organization better meet its mission or its "political" priorities?

c) How will those and other improvements result in cost savings, better occupant safety and comfort, etc.?

d) Looking at the answers to the previous three questions, what mix of the improvements will be the most compelling "drivers" and incentives for action?

2. Understand the Decision-Making Process

a) Understand the process that your organization follows in making decisions about building improvements.

b) Know about any policy and/or statutory provisions that may affect procurement and financing options. $^{1}$

c) Identify and involve key people who must approve policy, operating, and financial decisions.

d) Determine and get approval for your initial project target, development approach, and team to take next steps.

\footnotetext{
1 Policy and statutory provisions can affect: a) how operating funds may be used for capital improvements; $b$ ) how funds from internal and external sources can be combined to finance a project; c) how third-party technical and/or financial services may be procured and used; and d) eligibility for public financial incentives or subsidies. These can vary substantially by state, among market sectors, and among organizations. They are important!
} 


\section{Rebuild America Program Manual}

3. Determine Your Project Development Approach

a) Identify the general building set and the general improvements that best fit with the points above.

b) Examine what internal resources and external options are available to carry out those improvements.

c) Decide what mix of internal and external resources are needed to plan and implement the project.

Plan and Acquire Resources -- Plan your project, and get needed technical and financial resources

4. Establish Baseline Costs and Savings Potential

a) Determine current (baseline) energy utility and fuel costs.

b) Survey current performance efficiencies, and screen for energy savings opportunities.

c) Confirm the set of buildings and the general improvements that you will target.

5. Develop a Business Plan

a) Develop objectives and criteria, including:

- Quantified energy performance objectives, and specific financial criteria the project must meet

- Other important objectives, such as better occupant comfort and safety, performance guarantees

- $\quad$ Procedures for measuring and verifying performance and cost improvements, and their persistence.

- $\quad$ Types and sources (internal/external) of technical expertise that will be used

- $\quad$ Types and sources (internal/external) of project financing that will be used

- $\quad$ An estimate of the net present value of savings and benefits from the total project

- $\quad$ Cash-flow projections, inclusive of front-end development and back-end monitoring costs.

b) Determine needed facilities, scheduling, and management, including:

- $\quad$ A list of targeted buildings, a schedule, and priorities (optional) for implementing individual projects

- The person or persons who will have primary management and oversight responsibilities for the project.

6. Acquire Services and Financing

a) Get commitments and work plans for the internal staff, technical resources, and financial resources you will use.

b) Develop a procurement instrument(s) for any external services and financing that you need. 


\section{Rebuild America Program Manual}

c) Procure, negotiate, and match external and internal resources in accordance with your Business Plan.

Implement -- Finalize, install and commission, and measure results from your improvements

7. Finalize Project Definition

a) Conduct a detailed energy audit for each targeted building or facility.

b) Based on the audit, select improvements that meet or exceed your stated performance and financial criteria.

c) Complete architectural and engineering designs and specifications for the selected improvements.

d) Approve the final project design and allocate project financing for it.

8. Install the Improvements

a) Acquire materials, equipment, and labor in accordance with the final project design and specifications.

b) Schedule installation to minimize interference with normal building operations.

c) Consider coordinating energy efficiency improvements with other non-energy-related upgrades.

d) Ensure inspections are conducted at key points to verify work quality and design-build consistency.

9. Commission your Buildings

a) Inspect the completed project to ensure that improvements are installed according to design specifications.

b) Test the installed improvements to ensure that they perform according to design specifications.

c) Correct any improper installation or performance problems before final project acceptance.

d) Ensure that facility operations staff are trained on continuing operations and maintenance procedures.

10. Operate, Maintain, and Measure Results

a) Integrate project operations and maintenance into overall facility operations and maintenance.

b) Use appropriate procedures to measure and verify the performance and savings from the project.

c) Summarize and report performance and savings results regularly to key decision-makers.

d) Continue tracking over the long term to identify and correct for any performance deviations. 


\section{Section 3.2 Partnership Progress}

\section{Description:}

Effective Date: January 2004

The process under which Rebuild America partnerships submit their progress on implementing projects and other pertinent program activities. It is imperative that the Rebuild America program be able to get an accurate reading on where the program is and where it is going. We can only get to this point with the full participation and cooperation of our partnerships and Program Representatives.

\section{Purpose:}

To track Rebuild's progress, we must collect and/or calculate accurate data about each partnership's project activities, including:

$\begin{array}{ll}- & \text { Building sector } \\ \text { - } & \text { Building size (square feet) } \\ \text { - } & \text { Total project investment in retrofitting } \\ \text { - } & \text { Percent of private investment } \\ \text { - } & \text { Energy savings (Btus and } \mathrm{kWh}) \\ \text { - } & \text { Energy dollars saved }\end{array}$

The Rebuild Network will be the source for Partnerships and Program Representatives to submit, edit and track progress reporting.

Partnerships are now able to feed their project results directly into Rebuild Network. This will put cumulative program results at the fingertips of the National Program Team and individual partnership members.

Reporting on Rebuild Network gives each partnership firm numbers to provide to community leaders and their partners and helps elevate the stature of partnerships in their communities. It can help make the case for energy efficiency in each community to the elected officials, business leaders, building owners, school districts, municipal governments, potential partners and the media. The more aware communities are of each partnership's progress, the more likely they are to draw important local support to expand your efforts. Partnership's results may also motivate neighboring communities to join Rebuild America.

In addition to the above benefits, the Rebuild Network reporting system will output emissions reduction data, based on a partnership's inputs. Program awards will also be, at least in part, based on reported floor space retrofitted and energy saved.

Program Representatives are the front line in motivating partnerships to gather and input their retrofit results on a regular basis. Program Representatives are responsible to obtain and input into Rebuild Network the project results for those partnerships that cannot for whatever reason. 
1. Program Representatives ensure each of their partnerships know that Rebuild America has a progress tracking system, where it is on Rebuild Network, and the importance of regularly collecting and updating their partnership progress results and activities.

2. Program Representatives should emphasize the benefits of updating and maintaining partnership progress information on Rebuild Network.

3. Program Representatives should work with their partnerships in developing a plan for capturing progress and activities to best fit each partnership's needs.

4. Program Representatives should review, on a regular basis, the data input by their partnerships into Rebuild Network for accuracy and completeness.

Each Program Representative is ultimately responsible for their partnership's Rebuild Network information; the role of the Program Representative in keeping information up to date is even more critical when the partnership does not have Internet access.

\section{Section 3.3 Resources}

\section{Description:}

This section provides guidance for identifying and obtaining local resources that can support a partnership. Partnerships obtaining local resources is a cornerstone in the Rebuild America program and should be utilized whenever practical. For a Rebuild America partnership to become successful and subsequently selfsustaining, local resources must be employed.

This section includes obtaining resources from the Clearinghouse, Rebuild America public website, Rebuild Network and technical assistance, resources that can meet a partnership's needs whenever it is impractical to use local resources.

Ideally, a partnership will find all resource needs from the partners involved with the partnership and/or within the community. There are times when local resources are not adequate to meet the partnership's needs, are unavailable or are not cost effective to develop.

When a partnership requires resources that cannot be provided by the partners and are beyond the local community available services, Rebuild America can assist with resources from Rebuild Network, the Clearinghouse and technical assistance.

\section{Section 3.3.1 Local Resources}

\section{Description:}

Guidance for obtaining local resources that can support a partnership in identifying its goals and in developing its Rebuild Effective Date: January 2004 America Action Plan. 


\section{Purpose:}

When a Program Representative receives a request, or identifies a need for assistance, the first resources to be considered are those that are available locally. The goal is to build local leveraging and networking to help the partnership become self-sufficient.

"Local" does not need to be confined to the partnership's immediate community. Local may include the city, state, or region around the partnership. Sources can include a wide range of public, private, non-profit, financial or educational organizations.

Only after local resources have been exhausted or when local resources are unavailable to meet the identified need should the Program Representative pursue Rebuild America program resources.

\section{Process:}

The Program Representative is responsible for coordinating the identification of resources and delivery of assistance. The events should be documented and reported to the Team Leader and Technical Assistance Coordinator so those examples of good local resources can be made available to other Program Representatives and be enlisted for the Regional Team. A brief e-mail message is sufficient for reporting.

The Program Representative helps the partnership identify, clarify and document the assistance needed. The objective is for the Program Representative and the partnership contact to have a complete understanding of the need and the desired outcome.

The Program Representative works with the partnership to identify possible local resources. Often the desired resources are available within the planning partnership's organization or a partner organization. Generally, the Program Representative needs to take the guidance offered by the partnership contact as to the availability, capability and efficacy of the organization's resources. A personal visit or telephone call is usually sufficient to acquire the needed resource or service.

When the Program Representative and the contact determine it necessary to go beyond the partnership, a wide range of local public, private, non-profit, financial or educational organizations may be available to provide the needed assistance, and even interested in joining the partnership. Telephone books, Chambers of Commerce, economic development groups, and community advisory boards are some examples of resources that can identify local assistance.

If it is necessary to go beyond the local partnership's community, then expand your inquiries to a larger geographical area. Consider discussing the partnership's assistance need with other partnerships, other Program Representatives, the region's Team Leader, and county and state agencies.

Some assistance needs may be met using electronic media. Examples include use of the Internet, posting questions to relevant bulletin boards and discussion groups, and sending electronic mail messages to agencies and persons knowledgeable in the assistance area. 
If no local resources can be found and the alternatives are not providing the assistance needs, then request Rebuild America resources. That request should only be made through the Rebuild America Website.

\section{Section 3.3.2 Rebuild Network}

\section{Description:}

Rebuild Network is an Internet web site developed for the Rebuild America program team's use as a resource and information exchange tool.

\section{Purpose:}

The purpose is to provide guidance to the Program Representative in the use of Rebuild Network when assisting partnerships. This section will describe when, where, and how to access Rebuild Network.

\section{Process:}

To access Rebuild Network, you must have a computer, current Internet browser (Internet Explorer 5 or greater, Netscape 7 or greater) software, and the ability to access the Internet. The Rebuild Network has been successfully tested using most of the common browsers and software releases. The Rebuild Network requires a user name and password. If you are unsure of your access, do not have access to the Internet, or encounter problems, contact the Webmaster.

As a user of Rebuild Network, you have specific authorities and responsibilities. You are authorized to submit new information to the Rebuild Network as well as edit and delete your contact information. Program Representatives and Partnership Main Contacts can add, edit, and delete all information pertaining to their partnerships. Team Leads and State Partnership Leads typically have similar authorization. If you have questions about your authority, the authority of others, or wish to grant editing authority to other users, make your request known to the Webmaster.

Program Representatives assisting partnerships should be familiar with the features and navigation of Rebuild Network. Whenever resources specific to Rebuild America are needed or when local resources do not meet an identified planning partnership's need, consider Rebuild Network Program Info.

Using Rebuild Network, the Program Representative can make full use of Rebuild America contact information, a wealth of printed documents, building technical assistance using public and private services, Calendar events, and other resources found beneficial to partnerships. Desired information can be printed directly, downloaded, or acted on, such as requesting data or sending an e-mail. Most 


\section{Rebuild America Program Manual}

files on the Rebuild Network are in two formats, the native or original format and in an Adobe Acrobat file format.

General use of Rebuild Network:

The preferred approach is for action partnerships to maintain, update, and upload their partnership information to the Rebuild Network using the partnership's community profile page. Contact, partner, project key metrics, and success briefs can all be accessed from the partnership profile page within the Rebuild Network. The Program Representative should be prepared to assist the partnership in becoming familiar with the organization and navigation of Rebuild Network. Contact the Webmaster for assistance.

\section{Adding Partnerships to Rebuild Network}

New partnerships will be added to Rebuild Network by the Program Representative using the Partnership Application, located in the Communications, Program Info section of the Rebuild Network. In Phase I of this two-step process, program representatives can add new organizations in a pending status, with the required partnership main contact, address, and partnership planning questions. Phase II activates a pending partnership by adding web profile summary, and program joining date. For more information about this process, see the Partnership Application Help presentation. Once the partnership has been added, the Program Representatives, Partnership Main Contact and Regional Team Lead are encouraged to maintain pertinent and current information for the partnership within the Community Partnership section.

\section{Partnership Key Metrics}

The Results section is critical to documenting Rebuild America success. As partnerships commit to projects (sign a contract, obligate funds), the requisite information should be reported via the Rebuild Network Community partnership section. For an example of project reporting for one community partnership, Rebuild Alabama, see the partnership display page. Changes, corrections, and updates can be entered at anytime by the Program Representative, Partnership Main Contact, and others with appropriate editing authority. One can search for projects within the database by using the Project Search page.

\section{Report Center}

The Report Center is a dynamic location of program Key Metrics that are updated to provide the latest information about partnership projects. Located within the Solution Center, the Report Center provides national, regional, state and local partnership key metrics. Users can review the major categories of reports online, or download them into a MS Excel file for local processing. There are also event reports, partnership reports, and contact reports available within the report center.

\section{Uploading}

Contacts, documents, resources, and services available from partnerships can be uploaded into the Rebuild Network. Go to the appropriate section and complete the designated form. 


\section{Section 3.3.3 EERE Clearinghouse}

\section{Description:}

Effective Date: January 2004

The Energy Efficiency and Renewable Energy Clearinghouse is a valuable single point of contact for resources covering the array of efficiency and renewable energy topics.

\section{Purpose:}

The purpose is to provide guidance to the Program Representative in the services available from the Clearinghouse when assisting action partnerships. This section will describe when, where, and how to access the Clearinghouse for services when assisting partnerships.

The Clearinghouse provides services to a wide range of DOE programs. All Clearinghouse services are available to Rebuild America, with a few limitations. Limitations, when they apply, are quantity and, in some cases, controlled distribution. The Clearinghouse has voice mail coverage 24 hours a day as well as direct staff support five days a week.

\section{Process:}

Anyone may contact the Clearinghouse for assistance. Contacting the Clearinghouse may be done at any time, though the Program Representative and the partnership should still consider local resources first when searching for a solution. When contacting the Clearinghouse, the Program Representative and the Partnership should decide who will make contact based on the nature and complexity of the request.

The EERE Clearinghouse will provide services ranging from energy information to technical solutions. As an energy information provider, the Clearinghouse provides topical information on an as-requested basis.

To contact the Clearinghouse, email eereic@ee.doe.gov or call 888-EEREINFO.

\section{Section 3.3.3.1 Technical Assistance}

For an explanation of Rebuild America's Technical Assistance,

Effective Date: January 2004 see Section 7.0 - Products \& Services. 


\section{Section 3.3.4 Contributing Resources}

\section{Description:}

Effective Date: January 2004

This section describes how to contribute resources to the Rebuild America Program Products and Services offerings.

\section{Purpose:}

As Program Representatives provide guidance to their partnerships on their projects, they should keep in mind the resources that were used to plan and/or accomplish the projects. In addition, they should keep in mind that if a resource is developed as a result of a project, these resources are of interest to other Rebuild America partnerships considering the same type of projects.

\section{Process:}

When a resource has been identified as a benefit to other Rebuild America partnerships, Program Representatives and partnership are encouraged to make the resource available to other partnerships.

Once received, resources will be adapted as appropriate for ease of use and distribution to other partnerships. Credit and acknowledgements to authors and developers will be maintained.

Copyrighted materials cannot be accepted without permission of the copyright holder. To a limited extent, given a strong recommendation by a Program Representative or partnership Rebuild America is willing to pursue use agreements with copyright holders on a case by case basis.

Submit resources to via the Rebuild Network Solution Center. There, the Material Submission Form may be completed with the relevant information about the resource. This information will be reviewed by the Products and Services team to determine its usefulness for the overall program. If deemed appropriate, the Products and Services team will undergo the necessary steps to secure the resource and add it to Rebuild America's resource portfolio. 


\section{Section 4.0 Program and Partnership Promotion}

\section{Section 4.1 Overview and Rationale}

\section{Description:}

Rebuild America's Marketing and Communications Team provides valuable resources to Program Representatives who want to enhance their communications efforts with key decision-makers and community leaders. The Marketing and Communications Team is skilled in the full range of marketing and communications disciplines. The team is staffed with individuals with expertise in writing, editing, graphic design, Web sites, media relations, event management and public relations consulting and management.

Program Representatives and partnerships can not only utilize, but also contribute to useful Marketing and Communications program tools. The regular reporting of project and partnership metric results provides the necessary background information to produce valuable materials. As priority audiences for communications materials, it is helpful for Program Representatives and partnerships to provide feedback on existing materials as well suggestions for new materials. Rebuild America priorities related to Marketing and Communications include:

- Showcasing program results and energy efficiency and renewable energy technology deployment

- Implementing program positioning strategies, approaches and messages

- Supplying effective communications resources to

- Partnerships

- Program Representatives/State Energy Offices

- U.S. Department of Energy (DOE) Regional Offices and Headquarters

- Working with Strategic Partner counterparts on joint outreach activities

- Marketing sector-specific communications and outreach

- Showcasing high-profile Business Partner activities

- Documenting and promoting energy efficiency and renewable energy technology adoption

- Coordinating the National Conference

The following are some of the services Marketing and Communications provides to the Rebuild America program:

- $\quad$ Program news and information development

- Web site news and features

- $\quad$ EnergySmart Update newsletter (formerly Partner Update)

- $\quad$ Literature development

- Success stories

- Program fact sheets

- Program descriptions - one-pagers 
- $\quad$ Media relations

- $\quad$ Event planning and support

- $\quad$ Partnership certificates

- $\quad$ Partnership welcome kits

- Banner, poster and exhibit development

- $\quad$ DOE Headquarters support

- $\quad$ Flash Report and OWIP Report

How to Access Marketing and Communications Services:

\section{Project Assistance Center}

The Marketing and Communications Team provides services directly to Program Representatives. Partnerships seeking assistance from Marketing and Communications must first go through their designated Program Representative(s). The Program Representative must submit a request through the online Project Assistance Center available in the Rebuild America Network at www.rebuild.gov. You may consult the Marketing and Communications Team directly by calling the helpline at 202-4667868 or by emailing rebuildamerica@pcgpr.com, but an official request must be submitted before work will begin.

The following pages provide more detailed information about the services available to partnerships and Program Representatives through Marketing and Communications.

\section{Section 4.2 Communications and Partnership Promotion}

\section{Description:}

Rebuild America seeks high-impact opportunities to showcase program results and promote the value of technology deployment to stakeholder groups and decision-makers. At the national level, this includes DOE management and Congress. At the local level, it may include prospective partners and partnerships, public officials and others influential in the decisions to pursue energy-efficiency projects.

Web site:

\section{Description}

The Web site is a communications center serving the needs of everyone involved in the program. Increasing emphasis is being put on it because of its flexibility, efficiency and speed as a resource that informs, connects participants to each other and directs participants to other resources.

\section{Purpose}

- $\quad$ The Web site keeps participants informed about what is being done and tracks the progress of the program through its partnerships.

- The Solution Center within the Web site provides detailed information on how to plan, launch and complete projects.

- Channels of communication built into the Web site allow for Program Representative technical assistance requests through the Project Assistance Center (see section 4.1 for 


\section{Rebuild America Program Manual}

more details). Marketing and Communications assistance can be provided through this mechanism.

- $\quad$ News posted on the Web site informs people about what is being done. News serves as a source of ideas, a motivator, a form of recognition, a calendar of upcoming events and a record of accomplishment. News also may encourage more organizations to join the program.

\section{Program Representative/Partnership Contribution}

The Web site can help guide partnerships by providing step-by-step building improvement processes. Program Representatives and partnerships should:

- $\quad$ Read news stories to acquire ideas, general explanations and initial contacts.

- $\quad$ Go to the Solution Center for more detailed resources that allow project plans to be clarified, launched and completed.

- $\quad$ Use the assistance request mechanisms to obtain expert help on solidifying plans and carrying out projects.

- $\quad$ Update partnership descriptions as projects are launched and completed.

- $\quad$ Contact Marketing and Communications staff to publicize projects.

- $\quad$ Report the metrics of projects.

Program Representatives and partnerships should notify Marketing and Communications staff of potential news stories that can motivate others to accomplish building improvements. Notify Marketing and Communications staff by emailing rebuildamerica@pcgpr.com. The resulting stories will be posted on the Web site or become material for newsletter stories and Success Stories.

\section{Availability}

The Web site, at www.rebuild.gov, is available at all times. Revisions and updates will often be posted in certain sections of the site.

\section{EnergySmart Update:}

\section{Description}

EnergySmart Update, formerly called Partner Update, is the bimonthly newsletter of Rebuild America. Each issue is 12 pages of feature news and regular segments such as a calendar of upcoming events.

\section{Purpose}

The newsletter serves the interests of internal program participants and external audiences. The newsletter provides:

- Innovative ideas on energy efficiency and renewable energy.

- $\quad$ Successful project examples.

- $\quad$ Recognition for partnership and program achievements.

- Useful nuggets of program-related information.

- A basic understanding of cutting-edge technologies.

- $\quad$ Updates of Rebuild America program activities. 


\section{Rebuild America Program Manual}

Printed news is complementary to news on a Web site. The different media potentially reach different audiences and each has different advantages.

\section{Program Representative/Partnership Contribution}

The ideas and details of most newsletter stories come from Program Representatives and partnerships. If any representative or partnership knows of a project that might make a good news subject, the idea should be communicated to Marketing and Communications personnel by emailing rebuildamerica@pcgpr.com. The idea and information for a newsletter story may also be used as the starting point for a Web site story or a Success Story.

\section{Availability}

Copies of EnergySmart Update can be obtained from the Clearinghouse or downloaded from the program Web site. Program Representatives and partnerships receive hard copies in the mail.

\section{Flash Report/OWIP Report:}

\section{Description}

The Flash Report is a biweekly brief summary of news and calendar items of interest to Rebuild America participants and program allies. The OWIP Report is a weekly brief summary of news and calendar items of interest for participants in the programs of the Office of Weatherization and Intergovernmental Program.

\section{Purpose}

The primary role of a Flash Report is to alert readers to upcoming events across the country. It also provides capsule summaries of news subjects. The Marketing and Communications staff also contributes to weekly OWIP Reports, which primarily provide an in-house DOE readership with calendar-type brief summaries of recent or upcoming activities.

\section{Program Representative/Partnership Contribution}

The ideas and details of most Flash Reports come from Program Representatives and partnerships. If any representative or partnership wants to boost attendance at an upcoming event, details of the event should be posted in the Events section of the Web site and Marketing and Communications should be notified by emailing rebuildamerica@pcgpr.com.

\section{Availability}

The Flash Report is emailed to program participants and other interested parties. It also can be downloaded from the program Web site. Requests to be added to the email list can be made by emailing rebuildorders@rebuild.org. OWIP Reports are emailed to DOE personnel and contractors. 


\section{Media Outreach:}

\section{Description}

Mainstream and trade news media provide access to audiences that cannot necessarily be reached through events or in-house writing. Marketing and Communications staff contacts reporters and editors to pitch stories and to maintain good media relations.

\section{Purpose}

Mainstream news media have established audiences that in large cities can exceed 1 million readers, viewers or listeners. Trade press outlets have smaller but far more specialized readerships. Positive news coverage can create a more receptive climate among decision-makers for Rebuild America's work. Positive news coverage also can indirectly promote the work by enhancing the reputations of business and community partnerships involved in projects. When trying to market energy efficiency and renewable energy, there is substantially more "bang for the buck" if the marketing messages are magnified through the news media.

Media outreach provides:

- $\quad$ Promotion of Rebuild America partnerships and projects by spreading results-driven information to large numbers of potential partnerships.

- $\quad$ Creation of goodwill toward the program and its partnerships.

- $\quad$ Local recognition as a reward for good work.

- Promotion of the overarching goals of energy efficiency and renewable energy.

\section{Program Representative/Partnership Contribution}

Projects that merit the interest of the general public, the business community or other specialized audiences should be reported to the Marketing and Communications staff. Program Representatives and partnership leaders and specialists should make themselves available for interviews so that reporters can gather details and comments from local sources who are the best, most impressive specialists for the subject. Those interviews may be by telephone or at media events, such as at ribbon-cuttings.

\section{Availability}

Story ideas can be pitched to news media whenever appropriate. Projects can be of interest to the news media when they are planned, launched, underway or just completed. Program Representatives should make media outreach assistance requests through the Project Assistance Center (see section 4.1 for details).

\section{Event Support:}

\section{Description}

Support will be provided to high-profile events associated with a partnership, Business Partner, Strategic Partner, government official, or related program activity. Event support can include:

- $\quad$ Planning assistance to the designated Program Representative or partnership

- Media outreach to local outlets

- Materials suggestions (including signage and collateral materials) and possible production

- Promotional materials to gin up attendance

- Presentation and talking points assistance 


\section{Purpose}

Events create publicity for partnership efforts and successes. Rebuild America support in orchestrating such events results in a streamlined, and often smoother, process. Events may vary depending on their purpose and nature. However, standard event procedures will heighten an event's attendance, publicity and success.

\section{Program Representative/Partnership Contribution}

Event support requests can be made through the Project Assistance Center (see section 4.1 for details). Program Representatives must submit an event request with a minimum lead-time of six weeks. Requests with shorter lead times may not be accepted.

\section{Availability}

Event support is open to all high-profile partnership and program events. There may be up to four events supported per sector per fiscal year.

\section{Section 4.3 Marketing and Communications}

\section{Description:}

The deployment of community-based efforts is the heart of the Rebuild America program. Marketing and Communications resources are available to Program Representatives and partnerships to increase the visibility and success of partnerships and projects.

\section{Success Stories:}

\section{Description}

Each Success Story is an attractive two-page piece printed on the front and back of a single sheet. Each story contains anecdotal information and metric results with as much detail as the sources provide. Success Stories are created as information becomes available over the course of the year through data collection and other sources. The objective is to provide one story per market sector per fiscal year in each DOE region. At an earlier stage in the program, Success Stories were called "Close Ups."

\section{Purpose}

Success Stories are marketing materials for spreading project ideas and for encouraging more organizations to see the value in forming partnerships. Produced in the convenient physical form of advertising fliers, Success Stories can be handed out individually, stacked on tables at conferences and workshops, distributed in conference kits or media kits and mailed. They also can be used to explain a project within a partnership's community, as a way of garnering good public relations from good, results-driven, work. 


\section{Program Representative/Partnership Contribution}

The details of Success Stories come from Program Representatives and partnerships that have completed projects, or that at least have completed the first phases of projects. If any Program Representative or partnership knows of a project that might make a good Success Story, they should provide the project's history and metrics to the Marketing and Communications Team. They should also provide one or two high-resolution photographs in jpeg format at $300 \mathrm{dpi}$ and at least 3 inches wide by 2 inches deep. Program Representatives and partnerships can submit Success Story requests through the Success Story section of the Rebuild America Web site or by emailing rebuildamerica@pcgpr.com. The idea and information for a Success Story may also be used as the starting point for a news story written for print or Web site.

\section{Availability}

Copies of Success Stories can be obtained from the Clearinghouse or downloaded from the program Web site.

\section{General Fact Sheets, One-Pagers and Brochures:}

\section{Description}

Fact sheets, one-pagers and brochures are good "starter" information sources for people and partnerships new to the program. These are generally short overview pieces that explain Rebuild America, its sectors and partnerships. Two new marketing collaterals will be produced per sector per fiscal year. Examples of such publications include:

- $\quad$ Sector one-pagers (for each of the five Rebuild America sectors)

- $\quad$ Program metric briefs (for each of the five Rebuild America sectors plus hospitality and historic preservation)

- $\quad$ Products and Services fact sheets

- Tailored materials for high-profile sector, state or partnership activities

\section{Purpose}

Fact sheets, one-pagers and brochures can be used for:

- Recruiting new partnerships.

- Meeting with potential program alliances including Business Partners and Strategic Partners in addition to other federal programs, agencies, and government officials.

- Exhibiting at conferences and meetings (the pieces serve as handouts and collateral materials).

- Inclusion in welcome packages to new partnerships.

\section{Program Representative/Partnership Contribution}

Successful partnership examples, as reported through the data collection, will be included in these publications. Program Representatives and partnerships are invited to suggest fact sheet topics that will be useful in deploying Rebuild America's messages and mission. Such requests should be submitted through the Project Assistance Center (see section 4.1 for more details) at www.rebuild.gov. 


\section{Availability}

Electronic versions of fact sheets, one-pagers and brochures are available through the program Web site. Limited print editions are also available through the Rebuild America Clearinghouse by emailing rebuildorders@rebuild.org.

\section{Annual Report:}

\section{Description}

The Annual Report summarizes the work of a fiscal year, provides examples of the work and includes basic background information about the program.

\section{Purpose}

The Annual Report is first-of-all an accounting of what Rebuild America has been doing, so that federal policymakers and members of Congress can review the functioning of the program. The report also is a means of educating newcomers to the program, and it is used as a marketing tool to attract more partnerships to the program.

\section{Program Representatives/Partnership Contribution}

The Annual Report cannot do justice to Rebuild America unless Program Representatives and partnerships provide the grist of project accomplishments, especially in the form of metrics. Although some of the project descriptions are obtained from Web news stores and newsletter content, partnership reporting and Web site profile updates are essential in creating a comprehensive report.

\section{Availability}

The Annual Report is mailed to program participants and other interested parties. Copies also can be obtained from the Clearinghouse or downloaded from the Rebuild America Web site.

\section{Exhibits, Banners and Posters:}

\section{Description}

Exhibits, banners and posters are available as visual instruments for partnership or program participation in events, meetings, and conferences. Signage available through Rebuild America includes:

- $\quad$ Rebuild America exhibit with a changeable panel for sector displays

- EnergySmart Schools exhibit

- Table-top displays

- Rebuild America six-foot vinyl banner

- Rebuild America general and customized (on occasion for high-profile events) posters 


\section{Purpose}

Signage helps brand events and showcase event participants, sponsors and others. The visibility of Rebuild America is raised at an event where program signage is present.

\section{Program Representative/Partnership Contribution}

Program Representatives should make exhibit, banner and poster requests through the Project Assistance Center (see section 4.1 for details) with at least six weeks lead time.

\section{Availability}

Exhibits, banners and posters are available to all Program Representatives and partnerships. The request will either be handled by the Rebuild America Clearinghouse or by conference participation organizer. Requests should only be made in the cases of high-profile events and meetings. Requests may be prioritized based on the lead time given and level of event importance.

\section{Section 4.4 Business Partner Support}

\section{Description:}

Business Partners are important components of the Rebuild America network. Support for Business Partners is geared to create and project a unified message about energy efficiency, technologies and services to public and private audiences. These functions and materials include:

- $\quad$ Program logos and usage guidelines

- Feature Profiles of Premier Business Partners

- $\quad$ Fact sheets covering industry segments and Business Partner roles

- Media placements highlighting Business Partner accomplishments through Rebuild America projects

- $\quad$ Energy Technology Seminar promotion materials

\section{Purpose}

Materials for Business Partners support the strengthened relationship between Rebuild America and its industry partners established through the overhaul of the Business Partner program in Fiscal Year 2003. The revised program clarifies roles, responsibilities and expectations for both Business Partners and the Rebuild America program.

\section{Program Representative/Partnership Contribution}

Business Partners supply expertise, materials and financial support to the program through speaker presentations at technology seminars, Solution Center contributions and sponsorship at Rebuild America events. Business Partners are also asked to suggest ideas for and contribute to marketing materials for development. Suggestions can be made through the Business Partner team. As a Rebuild America Business Partner, each organization or company is asked to distribute print and electronic copies of materials to its membership and allies. 


\section{Availability}

Business Partner materials are available in electronic format at www.rebuild.gov. Print copies may also be available through Rebuild America Clearinghouse ordering at rebuildorders@rebuild.org.

\section{Program Logos and Usage Guidelines:}

\section{Description}

The Rebuild America logo has been modified to incorporate the Business Partner designation, including the Premier Business Partner designation created in Fiscal Year 2003.

\section{Purpose}

The Business Partner logo is provided as a means for industry partner organizations to promote their relationship with Rebuild America on product and service literature, Web sites and trade show exhibits. Actively promoting the relationship extends brand recognition for Rebuild America and adds the credibility to Business Partners for association with a federal program.

\section{Program Representative/Partnership Contribution}

Rebuild America Marketing and Communications created the logo with input from the Business Partner community on desired formats and optimum ways to make the logo available for use.

\section{Availability}

The Rebuild America Business Partner logos are available by logging into the Rebuild Network on the Web site under the Communications section.

\section{Feature Profiles of Premier Business Partners:}

\section{Description}

Feature profiles are created for each Business Partner that attains Premier status to highlight each partner's accomplishments and support of the Rebuild America program.

\section{Purpose}

Feature profiles allow the program to showcase the superior contributions of the most active industry partners. In addition, these profiles are made available directly to the Business Partner for inclusion in or on company Web sites, newsletters and other corporate communications.

\section{Program Representative/Partnership Contribution}

Business Partners supply, through the established points reporting system, source materials and direct interviews the information required to produce the profile. In many cases, Rebuild America partnerships and Program Representatives may be called upon or volunteer to contribute information and perspectives in drafting feature profiles. 


\section{Availability}

Premier Business Partner feature profiles are available on the Rebuild America Web site through a link from that Business Partner's main profile page. The profiles may also appear in other communications materials including the program newsletter.

\section{Industry Segment Fact Sheets:}

\section{Description}

Targeted fact sheets describe the various industry segments associated with Rebuild America through the Business Partners program.

\section{Purpose}

These fact sheets explain the technologies, products and services made available to Rebuild America through its Business Partners.

\section{Program Representative/Partnership Contribution}

Business Partners supply the source information for the fact sheets. A group of Program Representatives are asked to review and comment on new fact sheets in the draft stage before final production.

\section{Availability}

All program fact sheets are available online through www.rebuild.gov or through the Rebuild America Clearinghouse by emailing rebuildorders@rebuild.gov.

\section{Business Partner Media Placements:}

\section{Description}

News and feature articles are pitched and placed in trade press and local, regional and national media.

\section{Purpose}

These articles promote Rebuild America activities and industry support to key stakeholder audiences through placement in the publications they read and other targeted sources of media.

\section{Program Representative/Partnership Contribution}

Business Partners, community partnerships and Program Representatives are involved in the planning, creation and review of media placements, as appropriate. 


\begin{abstract}
Availability
Media placements are available through periodic media reports prepared for the program's management team. Additionally, where copyright clearances are granted, media placements are made available online through the Communications section of the Rebuild Network at www.rebuild.gov.
\end{abstract}

\title{
Technology Seminar Promotion Materials:
}

\section{Description}

Promotional materials for the Energy Technology and High Performance Schools seminars held around the country, include:

- Postcard event announcements

- Online event postings

- $\quad$ Media advisories (optional)

\section{Purpose}

These materials are designed to raise awareness of and draw attendance to the seminars.

\section{Program Representative/Partnership Contribution}

Community partnerships across the country host seminars. Program Representatives submit initial seminar requests to the Business Partners Team. All involved parties are invited to review and comment on seminar promotional materials during the draft stage of the planning process.

\section{Availability}

Event postings are available online in the Events section of www.rebuild.gov. Postcards are distributed electronically by the host organization.

\section{Section 4.5 Strategic Partner Support}

\section{Description:}

Strategic Partners serve as alliances and subject experts to Rebuild America partnerships. Materials for Strategic Partners are created to strengthen and market messages about energy efficiency to target audiences and memberships. These materials include:

- $\quad$ Logo art and usage guidelines

- Presentation templates and modules

- By-lined feature article placements 


\section{Purpose}

Support materials inform Strategic Partners and their memberships about the program, its objectives, mission and partnerships. By increasing membership knowledge of the program, these materials strengthen the alliance between Strategic Partners and Rebuild America.

\section{Program Representative/Partnership Contribution}

Strategic Partner support is requested by the Strategic Partners team. Strategic Partners are asked to suggest ideas for and contribute to marketing materials for development. As a Rebuild Strategic Partner, each organization is asked to distribute print and electronic copies of materials to its membership and allies.

\section{Availability}

Business and Strategic Partner materials are available in electronic format at www.rebuild.gov. Print copies may also be available through Rebuild America Clearinghouse ordering at rebuildorders@rebuild.org.

\section{Logo Art and Usage Guidelines:}

\section{Description}

The Rebuild America logo has been modified to incorporate the program's Strategic Partner designation into the design.

\section{Purpose}

Placing the Strategic Partner logo on brochures, newsletters and other publications and materials extends Rebuild America's brand recognition.

\section{Program Representative/Partnership Contribution}

The Strategic Partners Team contributed design and usage input for the new logo.

\section{Availability}

The logo is available to Strategic Partners online through the Communications section of the Rebuild Network at www.rebuild.gov. Specialized requests and permissions are cleared through Marketing and Communications by emailing rebuildamerica@pcgpr.com.

\section{Presentation Templates and Modules:}

\section{Description}

Electronic presentation templates and modules are created for all Rebuild America presentations. Standard modules include a program overview, technology components and project successes.

\section{Purpose}

Templates provide a consistent, professional appearance for Rebuild America presentations to key stakeholder audiences. The modules provide consistent messaging and positioning of the program to ensure that all program emissaries deliver a consistent, clear and concise description of the program. 


\section{Program Representative/Partnership Contribution}

Partners and program affiliated national laboratories conduct technical reviews of technology modules. Partnerships and Program Representatives contribute to and review these modules before they are posted.

\section{Availability}

Presentation templates and modules are available on the Web site through the Communications section of the Web site's Rebuild Network.

\section{By-lined Feature Articles:}

Description

Strategic Partner publications are ideal sources for featuring by-lined program articles. Such articles familiarize the readership with Rebuild America developments and partnership examples.

\section{Purpose}

These articles highlight and promote program activities and accomplishments in target market sectors through Strategic Partner memberships.

\section{Program Representative/Partnership Contribution}

By-lined feature articles are created, with assistance from Marketing and Communications, by partnership or Program Representatives with particular expertise pertaining to the project or other success being featured. They may contribute source material and information and/or an initial draft of the article. The publications editor will supply editorial guidance and possible revisions to the piece.

\section{Availability}

Published articles may be available through Strategic Partner publications, Web sites and (where reprint permissions can be obtained) through www.rebuild.gov.

\section{Section 4.6 Partnership Orientation and Recognition}

\section{Description:}

Effective Date: January 2004

Program Representatives have access to introductory program materials for new partnerships as well as acknowledgement options for existing partnerships. These tools can be used to both recruit and retain partnerships. 


\section{Welcome Package:}

\section{Description}

Representatives of new Rebuild America partnerships will receive a welcome package once a partnership agreement is signed. Package contents vary depending on the partnership's sector and region, but typically contain:

- A welcome letter from the respective Regional Team Lead with contact information for the partnership's Program Representative. The letter also includes the partnership representative's username and password to the Rebuild Network at www.rebuild.gov.

- General program fact sheets and information.

- $\quad$ Sector-specific materials.

- A current edition of the EnergySmart Update newsletter.

\section{Purpose}

In addition to welcoming partnerships to Rebuild America, these packages also familiarize new partnerships with the program and its available resources.

\section{Program Representative/Partnership Contribution}

Packages are sent out once a username and password are assigned to the new partnership contact. Timely submission of partnership agreements by partnerships and Program Representatives results in quicker delivery of welcome packages.

\section{Availability}

Welcome packages are available for representatives of new partnerships. The relevant Regional Team Lead and Program Representative are sent review and courtesy copies of the welcome letter.

\section{Certificates:}

\section{Description}

Certificates of appreciation and recognition are created for partnerships and Program Representatives to acknowledge program achievements. Certificates are signed by the Rebuild America National Program Manager.

\section{Purpose}

Appreciation and recognition certificates may be used to recognize:

- $\quad$ Benchmarks or milestones reached by Rebuild America partnerships.

- Energy-saving efforts by high-profile leaders associated with a partnership (for example town, county and state government officials).

- Dedicated program team members leaving or retiring from the program.

- New, high-profile partnerships (usually in coordination with a kick-off event).

- $\quad$ Exemplary Business and Strategic Partner efforts. 


\section{Rebuild America Program Manual}

\section{Program Representative/Partnership Contribution}

Program Representatives can make certificate requests through the Project Assistance Center (see section 4.1 for more details). A two to three sentence sample of appropriate certificate language, along with the name, title and organization of the recipient should all be included in the request.

\section{Availability}

Certificates are only available on an individual basis. They will either be sent electronically (for the printing responsibility of the Program Representative or partnership) or in hard copy through the mail. 


\section{Section 5.0 Expansion and Sustainability}

\section{Section 5.1 Adding New Partners}

\section{Description:}

Partnership building can be defined as "an evolving process that identifies, coordinates, evaluates and promotes specific actions which will help achieve partnership goals, sustain partnership activity and maximize community impact." One element in this process is adding new partners to an existing partnership.

\section{Purpose:}

Program Representatives are responsible for helping partnerships to form, develop, and sustain themselves. As part of these efforts, the ability to help identify potential new partners to enhance the activity, visibility, and sustainability of the partnership is crucial to long-term viability of the partnership.

It is not expected that Program Representatives themselves triage a community, interact with potential new partners, secure new partners' commitment, and modify action plans as a result of the addition of new partners. But, Program Representatives should be aware of the types of organizations and stakeholders that can enhance any given partnership and offer suggestions and guidance in developing a local strategy to attract and incorporate these new partners.

\section{Process:}

Make every effort to identify the challenges the community faces. These challenges could include:

$\begin{array}{ll}- & \text { local jobs declining } \\ - & \text { business retention } \\ - & \text { environmental issues } \\ - & \text { budget issues for schools } \\ - & \text { infrastructure problems } \\ - & \text { affordable housing }\end{array}$

Identify action items that will comprise the central core of any expansion strategy. Examples of possible action items include:

People and Organizations - Who are the individual and organizational stakeholders that can enhance the community partnership. These organizations and individuals can be resources and allies as well as building owners. 


\section{Rebuild America Program Manual}

- Commitment - Partners should have the same commitment to the community partnership that the partnership has to Rebuild America. An agreement that formalizes that commitment and provides acknowledgement of the effort and responsibilities of the partners and the partnership is encouraged. [See Section 2.1.2]

- $\quad$ Purpose - The purpose for expanding the partnership should be clearly developed. The partnership identifies how partnership expansion will continue the goals and objectives of the partnership.

- $\quad$ Technologies and Resources - The partnership identifies the existing local technologies and resources that are needed and those that already exist within the community.

- $\quad$ Structure - Partnership structure should be examined to ensure local organization and support for partnership activity. Structuring the partnership assists with organizational stability and credibility. Committees could be established for steering, project financing, marketing, technical assistance, etc. These committees work within the partnership community to support the activity of partners and the partnership.

- $\quad$ Evaluation - Partnership activity (benefits, impact, etc.) should be captured on a regular basis and reported on the Information Management System (IMS). Capturing this data and articulating it to the community and potential partners is an essential component in any new partner strategy. Potential partners must know the value Rebuild America efforts bring to them and the community.

- $\quad$ Promotion - Partnership develops a promotion and marketing strategy to attract interested building owners and resource partners. The basis of this promotion should be quantifiable benefits.

There are experienced Team Leaders that can assist you with partnership formation and expansion and access to peer exchange.

Members of Customer Services, Team Leaders, peers and others are available to assist you with this fundamental element to successful partnerships --- use them! 


\section{Section 6.0 Strategic Partners}

\section{Section 6.1 Strategic Partners Structure}

\section{Description:}

The process of developing and managing relationships with national level associations is one critical component the Rebuild America strategic goal to reach energy efficient building projects. Identified as "Strategic Partners", these associations represent decision makers in key end user markets that Rebuild America serves, which includes K-12 Schools, Public \& Multi-Family Housing, Colleges \& Universities, Local \& State Government, Financial Services, and Commercial Buildings.

\section{Purpose:}

Effective relationships with Strategic Partners produce access to resources and networks that are beneficial to Rebuild America's community partnerships and projects. These relationships create opportunities for new and existing building projects, and allow the association to offer additional services to its constituency. All of Rebuild America's Strategic Partners share the tactical goal of improving building performance for their members.

\section{Process:}

Strategic Partners fall into two general categories - those that have a direct connection to building owners, operators, or service providers, and those that are primarily policy or business support based.

In order to become a Strategic Partner, an organization creates a Strategic Alliance Agreement with Rebuild America. The voluntary, non-binding strategic alliance states that the Strategic Partner organization and Rebuild America share similar objectives, and will work in concert to accomplish those objectives. Rebuild America currently does not have any program goals to bring on new Strategic Partners. However, potential Strategic Partners will be evaluated on their strength in the five sectors.

\section{Section 6.2 Strategic Partners by Sector}

\section{K-12 Schools:}

K-12 Schools Sector Strategic Partners include:

- Association of School Business Officials (ASBO)

- Council of Educational Facility Planners International (CEFPI)

- Council of Great City Schools (CGCS)

Effective Date: January 2004 
- Modular Building Institute (MBI)

- National Energy Education Development (NEED) (energy education)

- National Energy Foundation (NEF)

- National School Board Association (NSBA)

- Alliance to Save Energy (ASE)

- U.S. Environmental Protection Agency, Energy Star®

School buildings are more than shells for classrooms they help shape attitudes toward learning, make statements to and about their communities, and consume large portions of annual school budgets. The quality and performance of school buildings can promote or inhibit good education.

Association of School Business Officials (ASBO) - ASBO represents over 6,000 members employed in public and private school entities, as well as community and junior colleges and state departments of education. Members include non-instructional employees at the local and national levels from specialized areas in school business management, as well as the generalized field of school business administration.

Council of Educational Facility Planners International (CEFPI) - CEFPI is dedicated to improving the planning and construction of school facilities across the nation. Facilities impact the learning, development, and behavior of the facility user-and the planning process is essential for quality facilities.

Council of the Great City Schools (CGCS) - The Council of the Great City Schools is an organization of the nation's largest urban public school systems, advocating K-12 education in inner-city schools and addressing common concerns and promising practices. Superintendents and board of education members from 58 cities govern CGCS across the country.

Modular Building Institute (MBI) - The Modular Building Institute is the trade association representing the companies involved in the manufacturing and distribution of commercial factory-built structures. $\mathrm{MBI}$ provides services and promotes professionalism through communication, education, and recognition. Dedicated to enhancing the future growth and capabilities of the industry, $\mathrm{MBI}$ encourages innovation and quality among its members.

National Energy Education Development (NEED) - NEED represents schools - from students, classroom teachers, administrators, facilities staff, and other school personnel as needed. NEED programs are provided to schools compliments of NEED's network of sponsors and supporters. Some school districts will adopt NEED as their "energy unit" in lieu of textbooks and other "vendor" types of programs. NEED is a comprehensive, full-service, program and can be utilized at many different levels and throughout several disciplines.

National Energy Foundation (NEF) - NEF is a nonprofit educational organization dedicated to the development, dissemination, and implementation of supplementary educational materials, programs, and courses. These resources for education relate primarily to energy, water, natural resources, science and math, technology, conservation, and the environment. All enrich and enhance teaching and learning. They recognize the importance and contribution of natural resources to our economy, to our national security, the environment, and our quality of life. 
National School Boards Association (NSBA) - NSBA encourages and prepares local school board members to become catalysts for educational change and agents for systemic reform in the public schools so that all students will be prepared to meet the challenges of tomorrow. Its innovative projects are designed to help school boards meet today's challenges while strengthening the American tradition of local representative governance of the public schools. In June 2003, Rebuild America obtained NSBA's official endorsement.

Alliance to Save Energy (ASE) - The Alliance to Save Energy is a nonprofit coalition of prominent business, government, environmental, and consumer leaders who promote the efficient and clean use of energy worldwide to benefit the environment, the economy, and national security. More than 75 corporations and business trade associations work together through the Alliance to promote greater investment in cost-effective energy efficiency. For more than 20 years, the Alliance has worked to make the benefits of energy efficiency understood and practiced in the United States and around the world. The Alliance has worked with industry groups, utilities, financial institutions, government entities, individuals, corporations, foundations, and communities. Its education, research, and advocacy programs and primary work is concentrated in the broad buildings, policy, international, and communications arenas. All programs emphasize that energy efficiency is the world's most critical energy resource.

U.S. Environmental Protection Agency, Energy Star® - Energy Star was introduced by the US Environmental Protection Agency in 1992 as a voluntary labeling program designed to identify and promote energy-efficient products, in order to reduce carbon dioxide emissions. EPA partnered with the US Department of Energy in 1996 to promote the ENERGY STAR label, with each agency taking responsibility for particular product categories. ENERGY STAR has expanded to cover new homes, most of the buildings sector, residential heating and cooling equipment, major appliances, office equipment, lighting, consumer electronics, and more product areas.

Rebuild America has collaborated with the small business, congregations, schools and government arms of the program. ENERGY STAR for Small Business is designed by and for small businesses and their advocates to increase their competitiveness through energy-efficiency. ENERGY STAR for Congregations provides free information and objective technical support to help faith-based organizations in their stewardship of financial and natural resources. ENERGY STAR for Schools has taken the best solutions for school leaders and ENERGY STAR for Government has taken the best solutions for government leaders and tailored them to specific organizational types. The result is a "suite" of offerings that meets the energy management needs of decision-makers at all levels of the organization.

\section{Public\& Multi-Family Housing:}

Public \& Multi-Family Housing Sector Strategic Partners include:

- National Association of Housing and Redevelopment Officials (NAHRO)

- U.S. Department of Housing and Urban Development (HUD)Office of Public and Indian Housing

- Association of Energy Engineers (AEE)

- Construction Market Data Group (CMDG)

- National Association of Energy Service Companies (NAESCO)

- Energy Services Coalition (ESC) 


\section{Rebuild America Program Manual}

There are approximately 1.3 million public housing units in the United States, in over 13,000 housing developments, which generate more than $\$ 1$ billion in utility bills annually.

Many public and multifamily housing facilities use outdated heating, cooling and lighting systems that consume more energy than newer technologies. Aging buildings and equipment, coupled with inefficient operations and maintenance practices contribute to higher operating costs for property owners.

National Association of Housing Rehabilitation Officials (NAHRO) - NAHRO is a professional membership organization comprised of 9,500 housing and community development agencies and officials throughout the United States who administer a variety of affordable housing and community development programs at the local level. Its mission is to create affordable housing and safe, viable communities that enhance the quality of life for all Americans, especially those of low- and moderateincome. NAHRO members administer 1,308,000 units of public housing (95\% of total) including over one million units of tenant-based Section 8 housing (94\% of total), and 500,000 units of other assisted housing. In all, NAHRO's members provide housing for more than 6.5 million low-income people.

The U.S. Department of Housing and Urban Development (HUD) - HUD participates as a Strategic Partner in order to increase the energy efficiency of housing for low income persons, reduce annual housing costs, reduce the disproportionate energy burden on low income households, improve utility management, and expand the use of renewable energy resources. For example, HUD entered into an Interagency Agreement (IAA) with the U.S. Department of Energy (DOE) to promote conservation and reduce utility costs in public housing through forums, research, demonstration, and evaluation. Under the IAA, Rebuild America established 31 new partnerships resulting in the initiation of more than 50 projects.

Association of Energy Engineers (AEE) - AEE is your source for information on the dynamic field of energy efficiency, utility deregulation, facility management, plant engineering, and environmental compliance. With a full array of information outreach programs from technical seminars, conferences, books to critical buyer-seller networking tradeshows, job listings, and certification programs, AEE offers a variety of information resource tools. As a growing membership organization, the overall strength of $A E E$ is highlighted by a strong membership base of over 8,000 professionals and recognized certification programs. The Association's network of 67 local chapters meet to discuss regional issues. AEE's roster of corporate members is a veritable "Who's Who" from the commercial, industrial, institutional, governmental, energy services, and utility sectors.

Construction Market Data Group (CMDG) - CMD Group has many sides. Look at us from one direction, and you'll see a respected supplier of timely project data. Turn the corner, and we're an innovative force in building product information. Take another step, and you'll find a reliable source for cost estimating. We're a multifaceted partner for your business. But our focus is singular and simple: To provide you with the information you need to succeed in the construction industry.

National Association of Energy Service Companies (NAESCO) - NAESCO is the united voice of the ESCo industry in the United States. In addition to serving as an advocate for the industry on national and state policy, it develops policies and programs that link persistency of energy savings measurement requirements, ensures that customers have freedom to choose among all energy 


\section{Rebuild America Program Manual}

service providers, and operates an accreditation program for ESCO. On behalf of the industry, NAESCO educates customers about industry successes and the breadth of industry experience, producing reports, case studies, data surveys, and articles for the general media to promote industry trends and practices.

Energy Services Coalition (ESC) - The ESC is a national nonprofit organization composed of a network of experts from a wide range of organizations working together at the state and local level to increase energy efficiency and building upgrades through energy savings performance contracting. It currently has members in 35 states, representing state energy offices, energy service companies, finance companies, energy engineering firms, vendors, building owners, federal agencies and other public and private entities. It is targeting the development of 10 State Chapters during 2001. Its services include workshops on project development, financing, and performance contracting, information on new energy-saving technologies and financing options for building and facility owners, and standardized documents, such as sample Requests for Proposals and contracts.

\section{College \& Universities:}

College and University Sector Strategic Partners include:

- Association of Higher Education Facilities Officers (APPA)

- National Association of Energy Service Companies (NAESCO)

- Association of Energy Engineers (AEE)

- Construction Market Data Group (CMDG)

- Energy Services Coalition (ESC)

- National Association of College \& University Business Officers (NACUBO)

As colleges and universities seek to deal more effectively with rising operating costs, need to expand campus facilities, the operation of outdated building and utility systems, creating maintenance programs that address equipment and building upkeep in advance of actual breakdowns can cut maintenance costs and greatly enhance the administration's control of its operating budget.

Association of Higher Educational Facilities Officers (APPA) - The Association of Higher Education Facilities Officers (APPA) is an international association dedicated to maintaining, protecting, and promoting the quality of educational facilities. APPA serves and assists facilities officers and physical plant administrators in colleges, universities, and other educational institutions throughout the United States, Canada, Mexico, and other countries worldwide. APPA serves the entire education community by conducting research and educational programs, producing publications, developing guidelines, and serving as a central information source for its members.

National Association of Energy Service Companies (NAESCO) - NAESCO is the united voice of the ESCo industry in the United States. In addition to serving as an advocate for the industry on national and state policy, it develops policies and programs that link persistency of energy savings measurement requirements, ensures that customers have freedom to choose among all energy service providers, and operates an accreditation program for ESCO. On behalf of the industry, NAESCO educates customers about industry successes and the breadth of industry experience, producing reports, case studies, data surveys, and articles for the general media to promote industry trends and practices. 
Association of Energy Engineers (AEE) - AEE is your source for information on the dynamic field of energy efficiency, utility deregulation, facility management, plant engineering, and environmental compliance. With a full array of information outreach programs from technical seminars, conferences, books to critical buyer-seller networking tradeshows, job listings, and certification programs, AEE offers a variety of information resource tools. As a growing membership organization, the overall strength of AEE is highlighted by a strong membership base of over 8,000 professionals and recognized certification programs. The Association's network of 67 local chapters meet to discuss regional issues. AEE's roster of corporate members is a veritable "Who's Who" from the commercial, industrial, institutional, governmental, energy services, and utility sectors.

Construction Market Data Group (CMDG) - CMD Group has many sides. Look at us from one direction, and you'll see a respected supplier of timely project data. Turn the corner, and we're an innovative force in building product information. Take another step, and you'll find a reliable source for cost estimating. We're a multifaceted partner for your business. But our focus is singular and simple: To provide you with the information you need to succeed in the construction industry.

Energy Services Coalition (ESC) - The ESC is a national nonprofit organization composed of a network of experts from a wide range of organizations working together at the state and local level to increase energy efficiency and building upgrades through energy savings performance contracting. It currently has members in 35 states, representing state energy offices, energy service companies, finance companies, energy engineering firms, vendors, building owners, federal agencies and other public and private entities. It is targeting the development of 10 State Chapters during 2001. Its services include workshops on project development, financing, and performance contracting, information on new energy-saving technologies and financing options for building and facility owners, and standardized documents, such as sample Requests for Proposals and contracts.

National Association of College \& University Business Officers (NACUBO) - NACUBO is a nonprofit professional organization representing chief administrative and financial officers at more than 2,100 colleges and universities across the country who are committed to excellence in higher education finance and administration. NACUBO's mission is to promote sound management and financial practices at colleges and universities, and to anticipate the issues affecting higher education. Founded in 1962, is governed by a board of directors composed of leaders in higher education financial management from around the country. A professional staff of approximately 50 persons, skilled in finance, management, and federal issues applicable to the field of higher education, is located in Washington, DC

\section{State and Local Government:}

State and Local Sector Strategic Partners include:

- American Public Power Association (APPA)

- U.S. Environmental Protection Agency, Energy Star®

- National Association of Counties (NACo)

- National Association of Energy Service Companies (NAESCO)

- National Association of State Energy Officials (NASEO)

- National Conference of State Legislators (NCSL) 
- Public Technology Inc. (PTI)

- Association of Energy Engineers (AEE)

- Construction Market Data Group (CMDG)

- Energy Services Coalition (ESC)

Local governments in the U.S. spend over $\$ 11$ billion per year on energy to run their office buildings, public spaces, and street lighting, 30 percent of which ( $\$ 3.4$ billion) is used unnecessarily on inefficient equipment. In many cases, energy expenses in public buildings are second only to salaries. Extracting, transporting, and burning fossil fuels, and the utilization and disposal of nuclear resources, also contributes to pollution and poses an array of health and national security concerns.

Opportunities exist for communities of all sizes to manage their energy use more efficiently and save money in the process. Many state and local governments are discovering they can significantly reduce utility bills by tracking energy consumption, purchasing more energy efficient products, and implementing management strategies to reduce energy use.

American Public Power Association (APPA) - APPA is the service organization for the nation's more than 2,000 community- and state-owned electric utilities. Its purpose is to advance the public policy interests of its members and their consumers, and to provide services to ensure adequate, reliable electricity at a reasonable price with proper protection of the environment. APPA advocates that a properly structured interstate wholesale electricity marketplace is the key to lowering consumer electricity costs, and that the federal government should play a strong role in ensuring the public interest in the flow of electricity along the interstate transmission system.

U.S. Environmental Protection Agency, Energy Star $囚$ - Energy Star was introduced by the US Environmental Protection Agency in 1992 as a voluntary labeling program designed to identify and promote energy-efficient products, in order to reduce carbon dioxide emissions. EPA partnered with the US Department of Energy in 1996 to promote the ENERGY STAR label, with each agency taking responsibility for particular product categories. ENERGY STAR has expanded to cover new homes, most of the buildings sector, residential heating and cooling equipment, major appliances, office equipment, lighting, consumer electronics, and more product areas.

Rebuild America has collaborated with the small business, congregations, schools and government arms of the program. ENERGY STAR for Small Business is designed by and for small businesses and their advocates to increase their competitiveness through energy-efficiency. ENERGY STAR for Congregations provides free information and objective technical support to help faith-based organizations in their stewardship of financial and natural resources. ENERGY STAR for Schools has taken the best solutions for school leaders and ENERGY STAR for Government has taken the best solutions for government leaders and tailored them to specific organizational types. The result is a "suite" of offerings that meets the energy management needs of decision-makers at all levels of the organization

National Association of Counties (NACo) - NACo is the largest national elected local government association in the country representing elected county officials. NACo is a committee intensive organization with strong input from member counties. NACo has a Large Urban County Caucus (representing the 100 most populated counties), the Rural Action Caucus, and the Joint Center for 


\section{Rebuild America Program Manual}

Sustainable Communities (a partnership with the U.S. Conference of Mayors). There is also an affiliate structure that includes state associations of counties.

National Association of Energy Service Companies (NAESCO) - NAESCO is the united voice of the ESCo industry in the United States. In addition to serving as an advocate for the industry on national and state policy, it develops policies and programs that link persistency of energy savings measurement requirements, ensures that customers have freedom to choose among all energy service providers, and operates an accreditation program for ESCo. On behalf of the industry, NAESCO educates customers about industry successes and the breadth of industry experience, producing reports, case studies, data surveys, and articles for the general media to promote industry trends and practices.

National Association of State Energy Officials (NASEO) - NASEO is a nonprofit organization affiliated with the National Governors' Association, whose core members are Governor appointed energy officials from the states and territories, was formed to provide state leadership on energy issues by being involved in shaping national energy issues and policies. NASEO serves as the official state voice in Washington to inform the Administration, the Congress, and regional and other national organizations about the specific energy priorities and concerns of states and territories. Members of NASEO design and operate the State Energy Program (SEP) and are focused on reducing the state energy bill for all economic sectors and to lead by example in making state facilities more energy efficient.

National Conference of State Legislatures (NCSL) - NCSL is an organization of both legislative staff and legislators in the 50 states and the nation's commonwealths and territories and serves as the link between state lawmakers and members of Congress. It is the place where members and staff turn for assistance in doing their jobs. NCSL provides its members technical assistance, information, research, publications, consulting services, meetings and seminars. The Conference serves as an effective voice for states in Washington, D.C.

Public Technology, Inc. (PTI) - PTI is a non-profit association that serves as the technology resource organization for the National League of Cities, the National Association of Counties, and the International City/County Management Association. It operates the Urban Consortium, a network of large local governments, which represents America's largest and most progressive cities and counties, and serves as a catalyst for research and development in emerging technologies that can solve problems facing local governments.

Association of Energy Engineers (AEE) - AEE is your source for information on the dynamic field of energy efficiency, utility deregulation, facility management, plant engineering, and environmental compliance. With a full array of information outreach programs from technical seminars, conferences, books to critical buyer-seller networking tradeshows, job listings, and certification programs, AEE offers a variety of information resource tools. As a growing membership organization, the overall strength of $A E E$ is highlighted by a strong membership base of over 8,000 professionals and recognized certification programs. The Association's network of 67 local chapters meet to discuss regional issues. AEE's roster of corporate members is a veritable "Who's Who" from the commercial, industrial, institutional, governmental, energy services, and utility sectors. 
Construction Market Data Group (CMDG) - CMD Group has many sides. Look at us from one direction, and you'll see a respected supplier of timely project data. Turn the corner, and we're an innovative force in building product information. Take another step, and you'll find a reliable source for cost estimating. We're a multifaceted partner for your business. But our focus is singular and simple: To provide you with the information you need to succeed in the construction industry.

Energy Services Coalition (ESC) - The ESC is a national nonprofit organization composed of a network of experts from a wide range of organizations working together at the state and local level to increase energy efficiency and building upgrades through energy savings performance contracting. It currently has members in 35 states, representing state energy offices, energy service companies, finance companies, energy engineering firms, vendors, building owners, federal agencies and other public and private entities. It is targeting the development of 10 State Chapters during 2001. Its services include workshops on project development, financing, and performance contracting, information on new energy-saving technologies and financing options for building and facility owners, and standardized documents, such as sample Requests for Proposals and contracts.

\section{Commercial Buildings:}

Commercial Building Sector Strategic Partners include:

- American Institute of Architects (AIA)

- Association of Energy Engineers (AEE)

- Construction Market Data Group (CMDG)

- Energy Services Coalition (ESC)

- U.S. Environmental Protection Agency, Energy Star®

- National Association of Energy Service Companies (NAESCO)

- National Main Street

- Association of Small Business Development Centers (ASBDC)

Rebuild America partnerships are reaching out to building owners, property managers, and businesses to help them achieve greater efficiencies in the lighting, space heating, cooling and water heating expenses that today account for over 60 percent of total commercial energy use.

American Institute of Architects (AIA) - The AIA has been advancing the value of architects and architecture for more than 135 years. Providing its members with resources and a collective voice of the profession, the AIA is a professional choice for more than 63,000 architects and allied professionals.

Association of Energy Engineers (AEE) - AEE is your source for information on the dynamic field of energy efficiency, utility deregulation, facility management, plant engineering, and environmental compliance. With a full array of information outreach programs from technical seminars, conferences, books to critical buyer-seller networking tradeshows, job listings, and certification programs, AEE offers a variety of information resource tools. As a growing membership organization, the overall strength of $A E E$ is highlighted by a strong membership base of over 8,000 professionals and recognized certification programs. The Association's network of 67 local chapters meet to discuss regional issues. AEE's roster of corporate members is a veritable "Who's Who" from the commercial, industrial, institutional, governmental, energy services, and utility sectors. 


\section{Rebuild America Program Manual}

Construction Management Data Group (CMDG) - Construction Market Data provides, complete, accurate and timely project information through all stages of construction. Construction Market Data supplies industry data through productive leads, project reports, contact lists, and market penetration analysis and sales evaluation reports. Any of these products can pinpoint a county, look at a state, or cover the country. Data is delivered via paper, e-mail or Internet.

Energy Services Coalition (ESC) - The ESC is a national nonprofit organization composed of a network of experts from a wide range of organizations working together at the state and local level to increase energy efficiency and building upgrades through energy savings performance contracting. It currently has members in 35 states, representing state energy offices, energy service companies, finance companies, energy engineering firms, vendors, building owners, federal agencies and other public and private entities. It is targeting the development of 10 State Chapters during 2001. Its services include workshops on project development, financing, and performance contracting, information on new energy-saving technologies and financing options for building and facility owners, and standardized documents, such as sample Requests for Proposals and contracts.

U.S. Environmental Protection Agency, Energy Star $§$ - Energy Star was introduced by the US Environmental Protection Agency in 1992 as a voluntary labeling program designed to identify and promote energy-efficient products, in order to reduce carbon dioxide emissions. EPA partnered with the US Department of Energy in 1996 to promote the ENERGY STAR label, with each agency taking responsibility for particular product categories. ENERGY STAR has expanded to cover new homes, most of the buildings sector, residential heating and cooling equipment, major appliances, office equipment, lighting, consumer electronics, and more product areas.

Rebuild America has collaborated with the small business, congregations, schools and government arms of the program. ENERGY STAR for Small Business is designed by and for small businesses and their advocates to increase their competitiveness through energy-efficiency. ENERGY STAR for Congregations provides free information and objective technical support to help faith-based organizations in their stewardship of financial and natural resources. ENERGY STAR for Schools has taken the best solutions for school leaders and ENERGY STAR for Government has taken the best solutions for government leaders and tailored them to specific organizational types. The result is a "suite" of offerings that meets the energy management needs of decision-makers at all levels of the organization

National Association of Energy Service Companies (NAESCO) - NAESCO is the united voice of the ESCo industry in the United States. In addition to serving as an advocate for the industry on national and state policy, it develops policies and programs that link persistency of energy savings measurement requirements, ensures that customers have freedom to choose among all energy service providers, and operates an accreditation program for ESCo. On behalf of the industry, NAESCO educates customers about industry successes and the breadth of industry experience, producing reports, case studies, data surveys, and articles for the general media to promote industry trends and practices.

National Main Street - Since 1980, the National Main Street Center has been working with communities across the nation to revitalize their historic or traditional commercial areas. Based in historic preservation, the Main Street approach was developed to save historic commercial 


\section{Rebuild America Program Manual}

architecture and the fabric of American communities' built environment. Equally important, it has become a powerful economic development tool as well. Today Main Street encompasses more than 1,400 community members, ranging from small to large urban.

Association of Small Business Development Centers (ASBDC) - The mission of the Association of Small Business Development Centers is to represent the collective interest of our members by promoting, informing, supporting and continuously improving the SBDC network, which delivers nationwide educational assistance to strengthen small/medium business management, thereby contributing to the growth of local, state and national economies. Small business is the engine of economic growth. There are currently over 22 million small businesses in America - and the number is growing rapidly, with over 800,000 started last year, alone.

\section{Resource Information:}

Regional Representatives have access to the publications, Web pages, success stories, online directories and other tools and services provided by the Strategic Partners. In order to access the decision makers in market sectors and Strategic Partners, contact Nick Keller, Manager, Rebuild America, Strategic Partners. For more information on the resources the Strategic Partners have available for regional partnerships, please visit www.rebuild.org. 


\section{Section 7.0 Products \& Services}

\section{Section 7.1 Products \& Services Structure}

\section{Description:}

This section describes the resources available to assist partnerships in completing energy projects and the procedures to obtain them.

\section{Purpose:}

The purpose of Products and Services is to provide resources to community partnerships to assist them with successfully planning and executing energy saving projects. A brief description of the purpose of each follows.

\section{PRODUCTS}

Products are defined as anything tangible or downloadable that Rebuild America has to offer its partnerships, via the program's website, to help them complete their projects. This includes printed or electronic documents, CDs, software, online tools, websites, etc. Program staff should utilize the program website as their primary vehicle for accessing the program's products. The purpose of providing these products is to create a simple and streamlined approach for making useful decisional information directly available to the partnerships and program staff.

\section{SERVICES}

Services are defined as all activities that require human intervention. While all are focused on helping a partnership moved towards the completion of projects, the services, themselves, may include phone conversations, presentations, site visits, design reviews, and many others. These services are primarily provided by the staff of DOE's National Laboratories, more specifically Oak Ridge National Lab, Pacific Northwest National Lab, National Renewable Energy Lab, and Lawrence Berkeley National Lab. Several types of assistance may be provided by outside experts or Business and Strategic Partners. The purpose of these services it to help partnerships overcome unique barriers and challenges that cannot be served by local or state provided resources.

The second major component of Services is technology seminars. These seminars provide partnerships and the general public an opportunity to learn about energy saving technologies and practices from Business Partners and other experts in a non-sales oriented environment. This is a key first step to moving partnerships through the process of executing energy saving projects.

\section{Process:}

\section{PRODUCTS}

The informational products provided by Rebuild America are primary located in the Solution Center Section of the program's website. The organization of the Solution Center is structured based on industry accepted project processes. The primary building project processes are low/no cost improvements, energy efficiency retrofit, major renovation, and new construction. In addition, the category of community energy is provided to capture all non-buildings related informational resources. Below is an outline of the major topical categories that are included in each project process. 


\section{Rebuild America Program Manual}

No/Low Cost Improvements

- $\quad$ Building Tune-ups

- $\quad$ Energy Management Systems

- Facilities Management

- $\quad$ Operations \& Maintenance

Energy Efficiency Retrofit

- Building Evaluation

- $\quad$ Contracting and Financing

- $\quad$ Technologies and System Design

- Specification \& Installation

Major Renovation

- Project Definition

- $\quad$ Contracting and Financing

- $\quad$ Technologies and Systems Design

- Design \& Documentation

- $\quad$ Building Commissioning

New Construction

- $\quad$ Project Definition

- $\quad$ Contracting and Financing

- $\quad$ Technologies and Systems Design

- $\quad$ Design \& Documentation

- $\quad$ Building Commissioning

Community Energy

- $\quad$ Electricity Reliability \& Restructuring

- Renewable Energy

- $\quad$ Energy Efficiency/Water Conservation/IAQ

- $\quad$ Energy/Economic Development

- Sustainability

- Transportation

- Waste Management/Recycling

Under each category, all resources are organized into three types: useful books and CDs; downloadable files; and helpful websites.

SERVICES

Description of Available Assistance

Except where noted the following assistance are available for or restricted from use with all building projects at the described project phase.

\section{Pre-Project Planning}

Available Services

- $\quad$ Support in developing the A/E service provider selection criteria

- $\quad$ Assist in designing and conducting master planning design charrettes

- $\quad$ Conduct technical seminars on technology processes, etc., for general education purposes

- $\quad$ Conduct "walk-thru" seminars to determine opportunities and project feasibility

- $\quad$ Assist in the partnership's buildings prioritization process 


\section{Rebuild America Program Manual}

\section{Restricted Services}

- $\quad$ Act as intermediary between partnership and service providers

- $\quad$ Negotiate on behalf of partnerships

- Make any project related decisions on behalf of partnership

- $\quad$ Conduct detailed or "investment grade" audits for partnerships

- $\quad$ Specify detailed systems recommendations

- $\quad$ Conduct detailed energy modeling

- $\quad$ Be a standing member of design team and attend all regular project meetings

- $\quad$ Be formally involved in competitive selection process

\section{Project Definition}

\section{Available Services}

- $\quad$ Support in developing the service provider/contractor selection criteria

- $\quad$ Assist in designing and conducting project level design charrettes

- $\quad$ Assist in evaluating whole building level project options (shape \& structure, economic constraints, technical issues, project management issues, etc.) to help ensure the energy \& environmental benefits of project are meeting the needs of the partnership

- $\quad$ Provide support to help justify the project. Create understanding of all factors related to project including

- benefits and costs, various levels of audit information, etc. (EE Retrofit)

\section{Restricted Services}

- $\quad$ Producing final contract language

- $\quad$ Reviewing proposed and negotiated contracts

- $\quad$ Acting as intermediary between partnership and service providers

- $\quad$ Negotiating on behalf of partnerships

- Making any project related decisions on behalf of partnership

\section{Design Phase/Building Evaluation}

\section{Available Services}

- $\quad$ Evaluate project design for Energy Star Label eligibility

- $\quad$ Conduct design review with goal of ensuring design has well integrated systems and a whole building design

- $\quad$ Provide operational cost estimates as part of design evaluation

- Conduct brief seminars on applicable technologies, financing, etc.

- $\quad$ Support in reviewing and developing building design guidelines (New construction)

- Review of construction documents and specifications with the goal of ensuring the design meets partnerships need as requested (i.e. Health, Energy, IAQ, Building Quality) (New construction)

- $\quad$ Participate in project "kickoff" meeting to help clarify project requirements and goals (EE Retrofit)

- $\quad$ Assist in determining need for brief feasibility study that helps determine if "investment grade" audit is warranted. Review results. (EE Retrofit)

\section{Restricted Services}

- $\quad$ Creating construction documents or writing specifications for partnership

- $\quad$ Approve design on behalf of partnership

- Interpret building code language to determine a project's compliance

- $\quad$ Producing final contract language

- $\quad$ Reviewing proposed and negotiated contracts

- $\quad$ Acting as intermediary between partnership and service providers

- $\quad$ Negotiating on behalf of partnerships

- $\quad$ Making any project related decisions on behalf of partnership 


\section{Rebuild America Program Manual}

\section{Contracts \& Financing}

\section{Available Services}

- $\quad$ Research state procurement regulations, policies and procedures for project applicability

- Identify alternative contracting vehicles, and provide applicable model contract documents for potential project use

- $\quad$ Assist in evaluating contracting \& financing options (What are best ways to contract to maximize efficiency?)

- $\quad$ Conduct review of draft contract and financing language and documents to identify opportunities (in statement of work and attachments, evaluation criteria, etc.) related to technologies

- $\quad$ Conduct review of draft language of RFP/RFQ for selecting an energy service company (EE Retrofit)

- $\quad$ After awarding of the service contract, assist in clarifying project parameters with partnership and contract awardees. (EE Retrofit)

\section{Restricted Services}

- $\quad$ Producing final contract language

- $\quad$ Review proposed and negotiated contracts

- $\quad$ Provide direct project financing

- $\quad$ Acting as intermediary between partnership and service providers

- $\quad$ Be formally involved in competitive selection process

- $\quad$ Provide support to anyone responding to Partnership RFP/RFQ

\section{Technologies and System Design}

\section{Available Services}

- $\quad$ Provide technology, systems, and alternative energy source recommendations that help to achieve goals as outlined in the project definition

- $\quad$ Conduct brief feasibility study to determine the appropriateness of a certain technology or system

- $\quad$ Conduct design review with goal of ensuring design has well integrated systems and a whole building design

- $\quad$ Provide recommendations for metering requirements to accurate track the performance of the building systems

- $\quad$ Conduct inspections and review the performance of existing systems to determine system integration, retrofit or O\&M opportunities

\section{Restricted Services}

- $\quad$ Detailed project energy modeling services (DOE2, EnergyPlus, etc)

- $\quad$ Make final technology \& system selections for partnership

\section{Construction}

\section{Available Services}

- Support in developing the construction management or general contractor selection criteria

- Review change orders to determine if project objectives are still achieved from the technical perspective

\section{Restricted Services}

- $\quad$ Authorizing change orders on behalf of partnership

\section{Building Commissioning}

\section{Available Services}

- $\quad$ Support in developing the commissioning service provider selection criteria

- $\quad$ Support in developing the scope and definition of the project's commissioning activities

- $\quad$ Evaluate project for Energy Star Label eligibility

- $\quad$ Provide recommendations for metering requirements to accurate track the performance of the building systems 


\section{Rebuild America Program Manual}

\section{Restricted Services}

- $\quad$ Provide commissioning services for partnership

- $\quad$ Meter buildings for revenue or utility use

Facilities Management

\section{Available Services}

- $\quad$ Provide guidelines for applicable operations and maintenance (O\&M) practices

- $\quad$ Help identify buildings with potential Energy Star label eligibility

- $\quad$ Conduct technical seminars for facility staff to train them on operations and maintenance practices

- $\quad$ Conduct walk-thru seminar with facility staff to find O\&M opportunities

- $\quad$ Review and support development of an energy policy or program

- $\quad$ Conduct brief review of utility rate structure to determine cost savings opportunities

\section{Restricted Services}

- $\quad$ Provide on site O\&M services

- $\quad$ Provide system or vendor product specific O\&M training

\section{Requesting Assistance}

In order to obtain the assistance described, a request must be made via the program's website. The program staff that will be able to request the assistance includes DOE regional team leaders, customer service representatives, and state representatives. Community partnerships will not be allowed to request assistance directly. The requests will be made via an online form located in the Project Assistance Center on the Rebuild Network and will include the following information. Those marked with (*) are required to be completed before the request can be submitted.

\section{Assistance Request Form Elements}

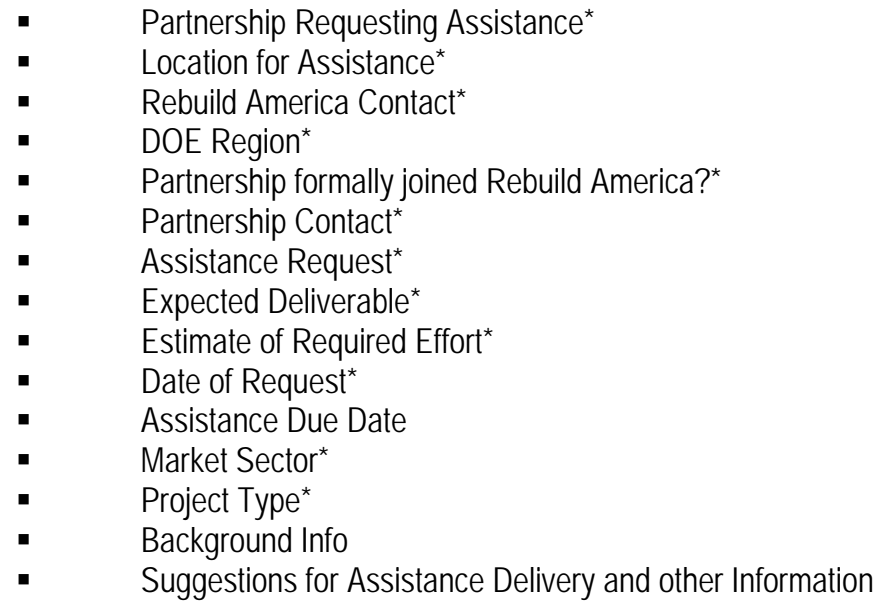

Upon completion the form will be forwarded directly to the Assistance Coordinator, who will review and accept the request, or contact the requestor for further information. The Assistance Coordinator, in council with the Products \& Services Manager and Program Manager, will have the authority to deny requests for assistance if they fail to meet the determination criteria. In turn, he will also have the authority to grant requests that don't meet the determination criteria if unusual circumstances require it, or if it is requested directly by the Program Manager. 


\section{Rebuild America Program Manual}

\section{Assistance Determination Criteria}

For each situation where Rebuild America provides assistance to its partnerships, all of the following questions must be answered "YES". Note: The assistance that falls under this criterion is that which requires national laboratory staff or others to perform a measurable amount of work to meet the need of the partnership. This includes any request that would require more than 4 hours of effort or requires travel. Assistance that is not included is basic information requests, phone calls, emails, and other short-term interactions.

1. Is the assistance request understandable and does it have a well-defined objective?

2. Does the service significantly increase or accelerate the project's ability to be successfully completed?

3. Is the service provided at a time in the project's life when it will have a significant impact?

4. Can the service be delivered to the partnership cost effectively?

5. Does the service help Rebuild America meet one of its strategic goals?

\section{Fulfilling the Assistance Request}

Once the assistance request is approved, it is assigned an assistance provider. This is done based on their area of expertise, availability, and ability to fulfill the request within the timeframe required. The assistance provider will then work with the partnership and program representative to provide the necessary assistance and fulfill the request. The assistance provider will also log their support activities and upload any deliverables in the Project Assistance Center on the program website.

\section{Closing out the Assistance Request}

When the assistance provider feels that they have met the requirements of the assistance request, they will indicate this in the activity log in the Project Assistance Center. An email notification will be sent to the requester with a copy to the Team Leader advising then that the assistance has been provided and that they have 30 days to closeout the request or the request will be automatically deemed successfully fulfilled by the system and closed. Once the provider indicates in the activity log that they have met the requirements of the assistance request, it is the responsibility of the requesting program representative to determine in the partnership is satisfied with the provided assistance. If the partnership is satisfied, the program representative will accept the provided assistance and formally close the request. If the partnership is not satisfied, the program representative will reject the assistance, and provide additional guidance on what needs to be accomplished to satisfy the partnership's need. This final step is a required task any program representative who makes an assistance request via the Project Assistance Center. However, if the program representative does not complete the closeout process within 30 days after service is provided the assistance center will automatically consider the request fulfilled and close it. 


\section{Section 8.0 Business Partners}

\section{Section 8.1 Business Partners Overview}

\section{Description:}

The Business Partner component of Rebuild America was initiated in 1999 as a means to formally connect private sector providers of buildings related products and services to the program and its partnerships, and to expand the market for energy efficiency.

The goals of Business Partner portion of Rebuild America are:

- $\quad$ Provide additional project-related technical and educational resources to the community partnerships

- $\quad$ Help create value-added relationships between the industry's products and services providers and the community partnerships.

\section{Purpose:}

The purpose of Business Partners is to create a mechanism for private sector providers of buildings related products and services to formally participate in Rebuild America and provide their expertise to the community partnerships.

Business Partners are considered local, regional and national resources within the Rebuild Program. The Rebuild America team relies on our Business Partners to provide valuable educational information to our Partnerships based on their extensive knowledge of today's effective technologies and best practices. Business Partners provide Partnerships with information on cutting-edge technologies and innovative services to ensure Rebuild America Partnerships are aware of all their options to assist in the planning and implementation of energy efficient projects.

Business Partners are invited to participate in broader events including Rebuild America's bi-annual national conference, technology-specific and broad-based educational seminars, and various other regional and partnership specific meetings. Rebuild America supports a host of other educational forums providing Business Partners the opportunity to offer input, expertise and support including educational CD-ROM based trainings, panel sessions, and various other specialized efforts.

\section{Process:}

Businesses can participate in Rebuild America by becoming a part of Business Partners. Business Partners provide products, services and educational tools to Rebuild America's community partnerships as well as assisting Rebuild America in promoting and advancing energy efficient practices in communities. Business Partners range from small local businesses that serve a specific 


\section{Rebuild America Program Manual}

community base, to national corporations that have various offices and representatives available to serve Community Partnerships throughout the United States.

\section{Prospects}

Prospective Business Partners are identified in a variety of ways. Program Representatives meet prospects at various regional and national events, prospects contact Rebuild America directly, and Rebuild America Partnerships can also identify prospects from companies that may already be working with their community partnership, or even those companies they feel could add to or benefit from the program. Any and all prospects should be forwarded on to the Business Partner Web Page on the Rebuild America website for more information.

\section{Becoming a Business Partner}

The process of becoming a Business Partner includes four components. Requirements to join the Rebuild America team as a Business Partners are:

1. Obtaining an understanding of how Business Partners interact with Rebuild America and the participation point system required to remain an active Business Partner.

2. Completing the "Intent to Participate" document

3. Signing the Business Partner agreement form acknowledging a commitment to Rebuild America.

4. Uploading company information on the Rebuild America web site to complete the company profile page.

Once the above requirements have been met to the satisfaction of the Rebuild Business Partner team and the prospective Business Partner, the prospect is officially welcomed to Rebuild America as a Business Partner. This allows the company access to Rebuild America and the EnergySmart Schools logos, a page on the Rebuild America website, access to begin contributing to Rebuild America publications and educational materials, receipt of opportunity postings and other partnership requests as well as a plethora of other opportunities.

\section{The Business Partner Agreement}

If an organization wishes to become a Business Partner they are required to complete a partner agreement. This agreement is used to clarify the relationship between DOE and the participating company. The company's senior management and DOE management staff will be required to sign the New Partner Agreement. This agreement is signed only once and is valid for the entire time that the company participates in the program.

Some of the basic language of the agreement includes:

The U. S. Department of Energy Rebuild America agrees to provide the following for all participating companies:

- Designate the company as a Rebuild America Business Partner 


\section{Rebuild America Program Manual}

- $\quad$ Create and sustain a standardized description of the company, its products/services, and programmatic activities on the Rebuild America website

- $\quad$ Provide, via electronic mail, all community partnership requests for assistance from Business Partners, (known in the program as "Opportunity Postings")

- Invite company representation for participation in Rebuild America events

- $\quad$ Provide access to and permission to use the Rebuild America name and logo for marketing and communications purposes (in accordance with the Program's established guidelines)

- $\quad$ Provide company opportunity to co-brand partnership educational resources with program and others

- $\quad$ Provide company opportunity to participate in packaged initiatives in partnership with national association (known in the program as a "Strategic Partner") and their membership

- $\quad$ Plan and schedule program outreach activities, such as technical seminars, that will provide the Business Partner opportunities to obtain participation points

Further, the U. S. Department of Energy Rebuild America will provide the following to all companies that are designated as Premier Business Partner:

- $\quad$ Premier identification on Rebuild America website - including highlight prominence as feature Business Partner on the site homepage, Business Partners section, and Solution Center

- Create specially written profile that would be included in Partner Update (program's newsletter), media information packages, etc.

- $\quad$ Offer first choice access to premium exhibit space at National Forum and Regional Peer meetings

- $\quad$ List company in Partner Update magazine and other periodicals as "premier" participant

- Provide invitations to special press events, and high level decision maker access opportunities

- $\quad$ Provide opportunity to participate in special awards programs

The Rebuild America Business Partner agrees to:

- Designate a Point of Contact within the company for Rebuild America correspondence

- $\quad$ Provide company description and information consistent with the provided template

- $\quad$ Provide company information, including identifying marks, solely for programmatic use

- $\quad$ Comply with minimum annual participation point requirements

- $\quad$ Establish a U.S. Department of Energy Rebuild America page on the company website consistent with the provided template

- $\quad$ Attend next Business Partners orientation meeting

- Identify and provide information on employees with training and outreach expertise for participation in Technical Seminars or other partnership education events

- $\quad$ Comply with requirements for reporting participation, results and inactivity

- $\quad$ Comply with program policies, including those on use of identification of the U.S. Department of Energy, Rebuild America, EnergySmart Schools, and other service marks

- $\quad$ Acknowledge that participation as a Business Partner does not result in an legal endorsement of the products, services, or practices of the company by the U.S. Department of Energy 


\section{The Participation Points System}

To create flexibility in the ways that a company can participate in Rebuild America, the program has created a points system to track participation. A set of activities and their corresponding point value are used to allow each company to participate in the program in a manner that is of best value and most resource efficient for them.

A Business Partner is required to accumulate a minimum of six (6) participation points each calendar year to be considered a participant in the Rebuild America program. If your company does not acquire six (6) participation points by December 31, a three-month grace period will be extended to acquire the needed points and continue to receive program benefits for the next year. Points acquired during the new calendar year will also be credited to that year's total. For any company that becomes a business partner after May 31 of any year, the minimum point requirement will be waived for the remainder of that calendar year.

A Business Partner that accumulates sixteen (16) participation points in a calendar year will attain Premier status. That status will start on the date the sixteen (16) points were attained, and the company will receive premier benefits for the remainder of that calendar year continuing through the next calendar year (e.g., Company A earns 16 points on July 15, 2002, becoming a Premier partner from that date until December 31, 2003). In order for a Business Partner to retain Premier status, another 16 participation points must be acquired in the next calendar year (e.g., Company A must acquire 16 participation points in 2003 to continue be a Premier partner in 2004). If the minimum16 participation points are not acquired in that next calendar year, they will not longer retain the Premier designation.

The following identifies the activities basis and their point values.

\section{1-Point activities:}

- Attend partnership-focused meetings and events

- $\quad$ Attend Business Partners regional meetings

- $\quad$ Complete project with Rebuild America partnership (verify with documentation)

- $\quad$ Report and verify participation via Rebuild America website

- $\quad$ Provide a referral that results in a new Business Partner

- $\quad$ Provide a referral that results in a new Community Partnership

\section{3-Point activities:}

- Participate in a technical seminar

- Provide an existing product or service resource to the Rebuild America Solution Center

- $\quad$ Attend and/or exhibit at the Rebuild America Forum or a Regional Peer Forum

- $\quad$ Attend annual Business Partner Summit meeting

- $\quad$ Provide other additional value-added resources

\section{5-Point activities:}

- Author and place article in trade magazine, etc., that highlights successful project with Rebuild America partnership

- Create and host a technical seminar and invite program staff and other Business Partners to participate 


\section{Rebuild America Program Manual}

- $\quad$ Financially sponsor the Rebuild America Forum or a Regional Peer Forum

- Financially sponsor a technical seminar

- $\quad$ Participate in an initiative in partnership with a Strategic Partner that focuses on a certain audience, market sector, or geographic region

- $\quad$ Provide use of company facility for educational seminars and other informative events

- $\quad$ Create and provide a new educational resource for the Solution Center that is co-branded with Rebuild America

- $\quad$ Provide resources for a partnership focused demonstration project

- Participate in a special Department of Energy sponsored activity

\section{Participation Tracking and Reporting}

Participation points will be tracked and verified on-line via the Rebuild America website. Activities are entered into the tracking system by Rebuild America program staff or the Business Partner main point of contact. Each activity will be verified by the other party; that is, activities entered by program staff will be verified by the Business Partner and vice versa. The U.S. Department of Energy Regional Office team leader or designated customer service representative will verify all activities that the Business Partner conducts with a single partnership. Only verified activities will earn participation points. The Business Partner will be kept apprised of their activities and accumulated participation points through a quarterly email message sent to the main point of contact. It will highlight the partner's activities and accumulated participation points in the calendar year to date. In addition to these email messages, certain status information will also be available anytime to the Business Partner in the protected area of the Rebuild America website.

\section{Partner Inactivity}

Continued participation requires regular accumulation of points. If the Business Partner has not accumulated the necessary six (6) annual participation points by the end of the calendar year, the partner will be notified of the situation and their current point total. Clarification will be provided and the grace period, ending March 31, to accumulate the needed points will be invoked. This will be the period of opportunity for scheduling participation in future planned activities (such as technical seminars) that will earn the participation points. If the points are not earned, or proper planning arrangements are not confirmed, the Business Partner will be notified that their participation status has become inactive. In such event, DOE recognition and other reciprocity will be discontinued, including removal of all relevant company information from the website, until the partner becomes active again or confirms the desire to no longer participate. 


\section{Appendix A Rebuild America Administration}

Effective Date: January 2004

\section{MANAGEMENT STRUCTURE}

The primary customers that the program will serve are Rebuild America Partnerships. The main contact with each partnership will be the Program Representative. To assure that the program serves partnerships well, and effectively supports each Program Representative, the Rebuild America Program will be operated with a National Management Team and six Regional Teams

\section{NATIONAL MANAGEMENT TEAM}

The National Management Team will be responsible for establishing budgets and accountable for ensuring performance of the Rebuild America Program. Objectives and activities for each function are defined below.

\section{Policy and Management}

The objective of Policy \& Management is to assure effective planning, decision-making, and evaluation for the Rebuild America program. "Management" will be carried out through a Program Management team made up of individuals responsible for various program functions. The National Program Manager will chair the Team and is responsible for its coordination, including setting program policy, overall budget preparation and defense, strategic alliances, and evaluation. The evaluation function helps make in-stream corrections based on performance to improve the program. The National Program Manager shall resolve any disputes.

Activities include but are not limited to:

- $\quad$ Overall strategy and policy

- $\quad$ Program planning and budgeting

- $\quad$ Annual budget making process

- Coordination and decision-making

- $\quad$ Resolution of conflicts

- $\quad$ Evaluation methods

- $\quad$ Strategic program alliances

- $\quad$ DOE/Lab/Contractor coordination

- $\quad$ Reporting guidelines for Team

- $\quad$ State grant solicitations

- $\quad$ RBA solicitations 


\section{Rebuild America Program Manual}

\section{Customer Service}

The objective of Customer Service is to recruit qualified partners, develop effective partnerships, and coordinate contacts and assistance services that aid them in planning and carrying out retrofit projects. This person shall manage activities to: (a) identify and recruit qualified partners into the program; (b) assist partners in partnership formation during their initial development stage; (c) assure continuing partnership follow-up, including brokering services to meet their implementation needs; (d) quantify benefits and value that partners gain from the program; and (e) train and coordinate program representatives and regional teams, to assure sound field management and continuing contacts needed to recruit and deliver services to partners; (f) develop and maintain strategic alliances with stakeholder groups.

Activities include but are not limited to:

- $\quad$ Identify status and administer needs assessments

- $\quad$ Quantify benefits for partners

- $\quad$ Recruiting \& qualifying strategy

- $\quad$ Manage \& train Regional Teams

- $\quad$ Manage and coordinate Strategic Partner integration

- $\quad$ Liaison with ROs \& SEOs

- $\quad$ Identify and recruit partners

- $\quad$ Assist partnership formation

- $\quad$ Coordinate service delivery

- $\quad$ Manage peer-to-peer assistance

- $\quad$ Manage contacts \& brokering

- Website development, content and maintenance

- Coordinate data capturing and reporting

\section{Regional Teams}

The ultimate success of the Rebuild America program depends heavily on staff who can aid in partnership formation and provide continuing assistance directly to partnerships at regional and local levels. To provide and manage these direct support activities, the program has established a field structure managed by Regional Team Leaders, who coordinate with Program Representatives responsible for individual partnerships. This structure is lead by and closely coordinated with DOE's Regional Offices.

- $\quad$ Regional Team Leaders are staff from ROs;

- $\quad$ Program Representatives may be staff from ROs, contractors, or State Energy Offices.

A description of general roles and responsibilities follows.

\section{Regional Team Leaders}

Regional Team Leaders have overall responsibility for setting and achieving RBA goals within a defined region. They are responsible for planning, coordinating and enhancing staff and resources within their region to: (a) identify and recruit partnerships into the Rebuild America (RBA) program; 
and (b) direct/assist Program Representatives in their actions to help partnerships plan and carry out retrofit projects. They work closely with RBA's National Management Team to define regional goals for Rebuild America, and to design and implement a team strategy that takes advantage of both regional and national resources to realize those goals. A Team Leader is designated for each of the six DOE regions.

Activities include but are not limited to:

- $\quad$ Set clear regional RBA goals \& priorities

- $\quad$ Regional marketing and assistance plan

- $\quad$ Define regional training needs

- $\quad$ Coordinate regional/national resources

- $\quad$ Identify leaders \& resources in the region

- $\quad$ Assign and coordinate Program Representatives

- $\quad$ Interface with national management team

- $\quad$ Assist Program Representatives in resolving problems

\section{Regional Offices}

DOE's Regional Offices (ROs) are the responsible organization for implementing Rebuild within the Region. Each Region assigns a Rebuild Team Leader to coordinate all Rebuild regional activities and to serve as a member of the Rebuild America National Management Team. All regional Rebuild activities are managed or coordinated by the Regional Team Lead.

Activities include but not limited to:

- Implement Rebuild America Strategic Plan

- $\quad$ Communicate RBA concept \& services

- $\quad$ Enlist participation of regional parties

- $\quad$ Coordinate with other DOE/EE programs

- $\quad$ Administer SEP Special Project and other grants

- $\quad$ Define specific RBA responsibilities within Regional Office

- $\quad$ Participate on the Rebuild America National Management Team

- $\quad$ Enlist and support partnerships

\section{Program Representatives}

Program Representatives are the primary continuing points of contact between individual partnerships and DOE. They have overall responsibility for conveying the concept and services of the Rebuild America (RBA) program to each partnership they develop or are assigned, and for assuring that each partnership develops a sound Action Plan containing clear goals and a realistic implementation strategy. They aid the partnership in identifying specific assistance needs essential to carry out their implementation strategy, coordinate with RBA staff in the delivery of assistance, and report on the activities and success of the partnership. They must also aid in identifying and developing partnerships. In general, Program Representatives should work within a defined region, as part of a Regional Team, and have primary and ongoing responsibility for program interactions. 


\section{Rebuild America Program Manual}

Activities include but are not limited to:

- $\quad$ Communicate RBA's concept \& services

- $\quad$ Assist in Action Plan development

- $\quad$ Aid in identifying assistance needs

- Coordinate delivery of assistance services

- $\quad$ Assist partnerships in resolving problems

- $\quad$ Insure all partnership metrics are reported in a timely and efficient manner

- $\quad$ Talk regularly with key partnership staff

- $\quad$ Participate in key partnership meetings

- $\quad$ Assist Partnership and Partners with project development process

- $\quad$ Coordinate Business and Strategic Partner support to partnership

- $\quad$ Request and follow-up on specific technical assistance needs and requests

- Identify "Close-up", "Case Study", "Flash Report" and Website index page story opportunities.

\section{Products \& Services}

The objective of this function is to develop or adapt, and to deliver products and services that will help partners plan and carry out retrofit projects. This person shall manage activities to: (a) work with customer service to define product and service needs of partnerships and the strategy, resources and expertise to meet them; (b) inventory and assess existing products and services, and negotiate access to those "outside" of the Rebuild America program; (c) develop new products and services and/or adapt existing ones to satisfy partner needs; (d) deliver direct technical assistance, training, workshops and other such services to partners; and (e) train program representatives in the use of these resources. "Products and Services" include written guides, analytical software, electronic services, workshops, and direct technical assistance.

Activities include but are not limited to:

- $\quad$ Design product/services needs assessment

- $\quad$ Inventory \& evaluate existing products

- $\quad$ Negotiate for use of "outside" products and services

- $\quad$ Do P\&S development \& delivery strategy

- $\quad$ Assure sound resources and expertise

- $\quad$ Develop written guides \& software

- $\quad$ Manage and coordinate Business Partners integration

- $\quad$ Electronic services

- $\quad$ Train Program Representatives to use P\& S resources

- $\quad$ Manage P\&S delivery to partners

\section{Business Partners}

The objective of this function is to support the Rebuild America program consistent with the goals of Customer Service. Business Partners will provide Program Representatives and partnerships an avenue to access private sector products and services to help them accomplish their building improvement goals. This person shall manage activities to: (a) directly support the mission of the Rebuild America program; (b) deliver un-biased, non-prescriptive information; (c) provide direct 


\section{Rebuild America Program Manual}

support to the Program Representatives, their primary customers, and their direct link to partnerships; (d) coordinate communications to minimize duplication of effort and the possibility of causing confusion at the partnership/partner level.

Activities include but are not limited to:

- Support and Assist Program Representatives.

- Establish linkages between Business Partners and RBA Products and Services.

- Understand the needs of the partnerships, Program Representatives, and Customer Service.

- Align with RBA Sectors, Financial Services, and Contract Services.

- Manage Business Partner activity to ensure it is in alignment with Rebuild America goals and partnership needs.

- Publicize Business Partner resources and accomplishments utilizing the Rebuild America web site and Marketing and Communications.

\section{Marketing and Communications}

The objective of marketing and communications is to communicate Rebuild America activities and achievements, create and distribute general and targeted program marketing materials, and ensure that internal and external communications are effective and well supported. This person shall manage activities to: (a) develop and manage overall marketing strategies to improve national visibility, raise awareness of and advertise the program; (b) assure that partners get timely information on an ongoing basis after they join the program; (c) assure effective press and media relations; (d) provide awards and publicity that recognize partner achievements; and (e) support effective and ongoing team and partnership communications. This person shall be responsible for the design and production of all marketing products, and will assure a consistent look and message for all other products from the program.

Activities include but are not limited to:

- $\quad$ Overall RBA marketing strategy

- $\quad$ Program brochure design \& production

- $\quad$ Print and video PSAs

- $\quad$ Rebuild America National presentations

- $\quad$ Conference selection for participation

- $\quad$ Partnership recognition and awards

- $\quad$ Annual Report

- $\quad$ Partner notebook, partner profiles, \& reporting guidelines

- $\quad$ RBA newsletter \& magazine articles 


\section{Appendix B Resources}

\section{Appendix B.1 Forms}

\section{Description:}

Effective Date: January 2004

Contained in this section are examples of forms frequently used for the Rebuild America program.

The forms contained are listed below:

- $\quad$ Action Plan Checklist form

- Example Partner Agreement form

- Action Plan Review form

- $\quad$ Partnership Summary form

- $\quad$ Project Assistance Request form

- Technology Seminar Request form

- $\quad$ Professional Development Request form

- Material Submission form 


\section{ACTION PLAN Check-List}

\section{PARTNERSHIP NAME:}

\section{PROGRAM REPRESENTATIVE:}

\section{DOE REGION:}

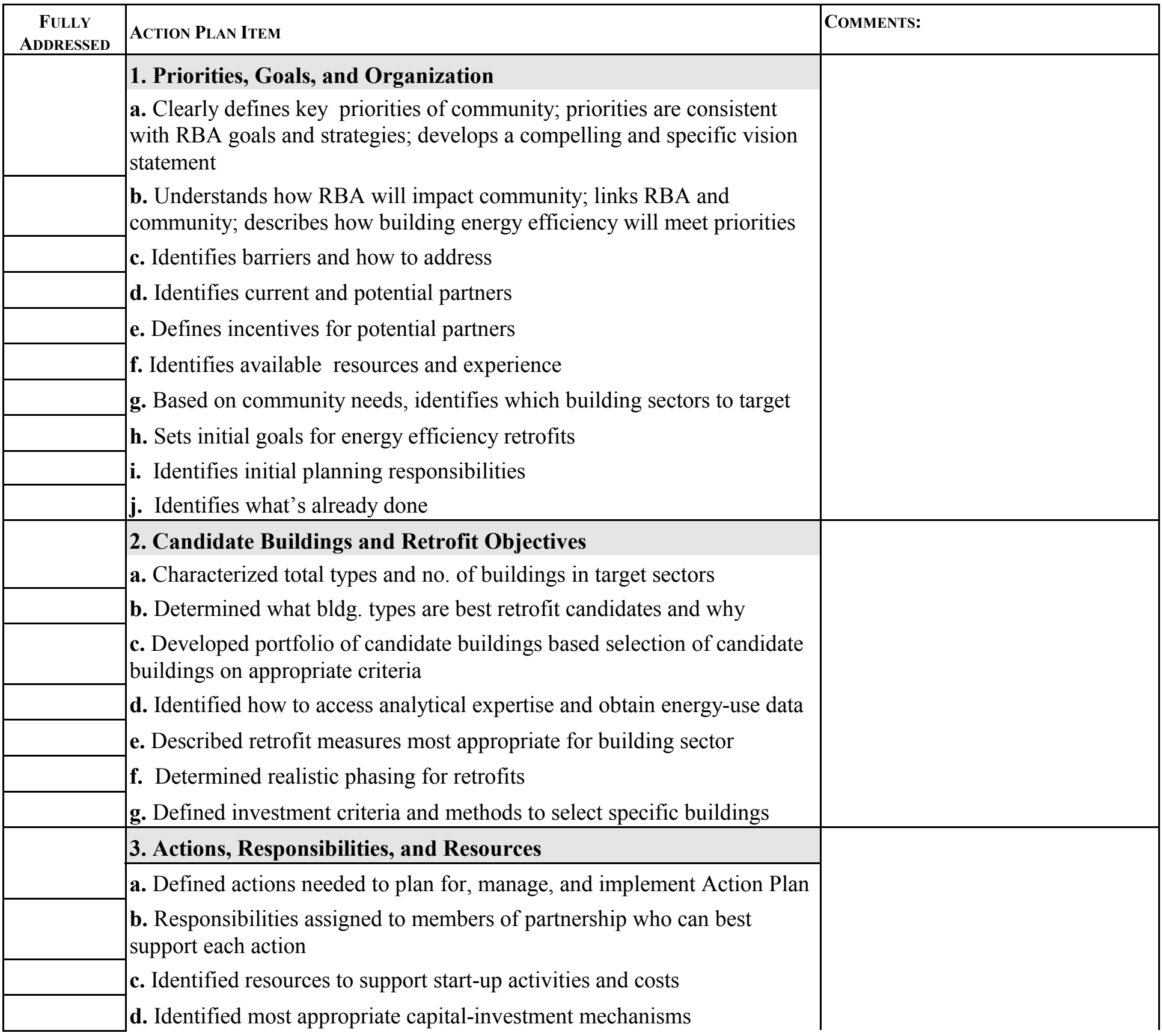




\section{ACTION PLAN Check-List}

\begin{tabular}{|c|c|c|}
\hline \multirow[t]{2}{*}{$\begin{array}{c}\text { FULLY } \\
\text { ADDRESSED }\end{array}$} & ACtion Plan Item & COMMENTS: \\
\hline & e. Identified strategies to assure continuity of program & \\
\hline & 4. Monitoring, Evaluation, and Reporting & \\
\hline & a. Defined information most important in measuring and reporting progress & \\
\hline & b. Defined methods for monitoring pre- and post-retrofit & \\
\hline & c. Identified sources of data post-retrofit performance & \\
\hline & d. Identified technical staff skills, responsibilities and equipment required & \\
\hline & $\begin{array}{l}\text { e. Determined what kind of reporting needed, what reporting schedule to } \\
\text { follow, and who is responsible }\end{array}$ & \\
\hline & 5. Promotion and Expansion & \\
\hline & $\begin{array}{l}\text { a. Established clear objectives, methods, and actions desired through } \\
\text { promotional actions }\end{array}$ & \\
\hline & b. Developed strategy for education, training, and recognition & \\
\hline & c. Identified individuals in community who will be champions & \\
\hline & d. Identified community vehicles for promotion and expansion & \\
\hline & e. Developed objectives for long-term expansion & \\
\hline & f. Linked market approach to all other actions & \\
\hline
\end{tabular}

Inclusion of Rebuild America Program Goals in Action Plan
AdDressed
ACTION PLAN GOAL
BRIEF DESCRIPTION

1. K-12 Schools

2. Innovative EE/RE Community 


\section{EXAmple Partner Agreement}

Rebuild America is a U.S. Department of Energy (DOE) program that helps local and regional Partnerships invest in their communities through improved energy efficiency in commercial and multifamily buildings, and public housing. Partnerships may be led by anyone and may comprise any combination of public and private organizations, but must inevitably include a representative of state or local government. DOE provides assistance, products, and services to help community Partnerships plan and carry out energy efficient retrofits.

\section{The Partner and the Rebuild America Partnership Agree that:}

Increasing the overall performance of buildings is a win-win opportunity for our communities and the nation. High performance buildings reduce building energy costs, increase available capital, spur economic growth, and improve working and living environments. Rebuild America, which includes its Partnership activities, its network of business, financial, and technical experts, the Energy Efficiency and Renewable Energy Clearinghouse, input from DOE National Laboratories, and local and national recognition, provides a viable strategy to achieve these goals.

\section{The Rebuild america Partnership agrees to:}

- Recognize the Partner as an active participant in the Rebuild America Partnership and include the Partner in activities of the Partnership.

- Promote Partner activities at the state and local levels to compliment this agreement.

- Promote exchanges of information and provide guidance information, workbooks, and reference contacts.

- Include the Partner in workshops and training on applicable energy efficiency and renewable energy topics.

- Assist the Partner in achieving their economic, energy, and environmental community and business objectives.

\section{Rebuild America Partner agrees to:}

- Develop Action Items to add to their community partnership Action Plan, which will plan, organize and carry out the building retrofits and/or other energy activities. The Partner's Action Items may include, but are not limited to, a description of proposed energy efficiency measures, a strategy to carry them out, and expected costs and savings. These Items will define means to verify the types and numbers of buildings treated, resultant energy savings, and the nature of technical assistance desired.

- Promote its participation in the Rebuild America program, using the DOE Rebuild America logo prominently on all marketing and information materials.

\section{Executive Acceptance by Partner Organization}

By signing below, your organization or company accepts this Rebuild America agreement with the Partnership.

\section{PARTNER:}

SIGNATURE:

NAME:

ORGANIZATION

ADDRESS
TITLE:

PHONE:

FAX:

E-MAIL: 


\section{ACTION PLAN REVIEW}

Mark an $\mathbf{X}$ in the appropriate box beside each item (a., b., c., etc.).

Write suggestions or comments in comments columns.

\begin{tabular}{|c|c|c|c|c|}
\hline $\begin{array}{c}\text { Fully } \\
\text { Addressed } \\
\end{array}$ & $\begin{array}{c}\text { Partially } \\
\text { Addressed } \\
\end{array}$ & $\begin{array}{c}\text { Not } \\
\text { Addressed } \\
\end{array}$ & & Comments: \\
\hline & & & 1. Priorities, Goals, and Organization & \\
\hline & & & $\begin{array}{l}\text { a. Clearly defines key priorities of community; } \\
\text { priorities are consistent with RBA goals and } \\
\text { strategies; develops a compelling and specific } \\
\text { vision statement }\end{array}$ & \\
\hline & & & $\begin{array}{l}\text { b. Understands how RBA will impact community; } \\
\text { links RBA and community; describes how } \\
\text { building energy efficiency will meet priorities }\end{array}$ & \\
\hline & & & c. Identifies barriers and how to address & \\
\hline & & & d. Identifies current and potential partners & \\
\hline & & & e. Defines incentives for potential partners & \\
\hline & & & f. Identifies available resources and experience & \\
\hline & & & $\begin{array}{l}\text { g. Based on community needs, identifies which } \\
\text { building sectors to target }\end{array}$ & \\
\hline & & & h. Sets initial goals for energy efficiency retrofits & \\
\hline & & & i. Identifies initial planning responsibilities & \\
\hline & & & j. Identifies what's already done & \\
\hline & & & 2. Candidate Buildings and Retrofit Objectives & \\
\hline & & & $\begin{array}{l}\text { a. Characterized total types and no. of bldgs in } \\
\text { target sectors }\end{array}$ & \\
\hline & & & $\begin{array}{l}\text { b. Determined what bldg. types are best retrofit } \\
\text { candidates and why }\end{array}$ & \\
\hline & & & $\begin{array}{l}\text { c. Developed portfolio of candidate buildings; } \\
\text { based selection of candidate buildings on } \\
\text { appropriate criteria }\end{array}$ & \\
\hline & & & $\begin{array}{l}\text { d. Identified how to access analytical expertise } \\
\text { and obtain energy-use data }\end{array}$ & \\
\hline & & & $\begin{array}{l}\text { e. Described retrofit measures most appropriate } \\
\text { for building sector }\end{array}$ & \\
\hline & & & f. Determined realistic phasing for retrofits & \\
\hline & & & $\begin{array}{l}\text { g. Defined investment criteria and methods to } \\
\text { select specific buildings }\end{array}$ & \\
\hline
\end{tabular}




\begin{tabular}{|c|c|c|c|c|}
\hline $\begin{array}{c}\text { Fully } \\
\text { Addressed }\end{array}$ & $\begin{array}{c}\text { Partially } \\
\text { Addressed }\end{array}$ & $\begin{array}{c}\text { Not } \\
\text { Addressed }\end{array}$ & & Comments: \\
\hline & & & 3. Actions, Responsibilities, and Resources & \\
\hline & & & $\begin{array}{l}\text { a. Defined actions needed to plan for, manage, and } \\
\text { implement Action Plan }\end{array}$ & \\
\hline & & & $\begin{array}{l}\text { b. Responsibilities assigned to members of } \\
\text { partnership who can best support each action }\end{array}$ & \\
\hline & & & $\begin{array}{l}\text { c. Identified resources to support start-up activities } \\
\text { and costs }\end{array}$ & \\
\hline & & & $\begin{array}{l}\text { d. Identified most appropriate capital-investment } \\
\text { mechanisms }\end{array}$ & \\
\hline & & & $\begin{array}{l}\text { e. Identified strategies to assure continuity of } \\
\text { program }\end{array}$ & \\
\hline & & & 5. Promotion and Expansion & \\
\hline & & & $\begin{array}{l}\text { a. Defined information most important in } \\
\text { measuring and reporting progress }\end{array}$ & \\
\hline & & & $\begin{array}{l}\text { b. Defined methods for monitoring pre- and } \\
\text { post-retrofit }\end{array}$ & \\
\hline & & & $\begin{array}{l}\text { c. Identified sources of data post-retrofit } \\
\text { performance }\end{array}$ & \\
\hline & & & $\begin{array}{l}\text { d. Identified technical staff skills, } \\
\text { responsibilities and equipment required }\end{array}$ & \\
\hline & & & $\begin{array}{l}\text { e. Determined what kind of reporting needed, } \\
\text { what reporting schedule to follow, and who } \\
\text { is responsible }\end{array}$ & \\
\hline & & & 4. Monitoring, Evaluation, and Reporting & \\
\hline & & & $\begin{array}{l}\text { a. Established clear objectives, methods, and } \\
\text { actions desired through promotional actions }\end{array}$ & \\
\hline & & & $\begin{array}{l}\text { b. Developed strategy for education, training, } \\
\text { and recognition }\end{array}$ & \\
\hline & & & $\begin{array}{l}\text { c. Identified individuals in community who } \\
\text { will be champions }\end{array}$ & \\
\hline & & & $\begin{array}{l}\text { d. Identified community vehicles for } \\
\text { promotion and expansion }\end{array}$ & \\
\hline & & & $\begin{array}{l}\text { e. Developed objectives for long-term } \\
\text { expansion }\end{array}$ & \\
\hline & & & f. Linked market approach to all other actions & \\
\hline
\end{tabular}




\section{Partnership Summary Sheet}

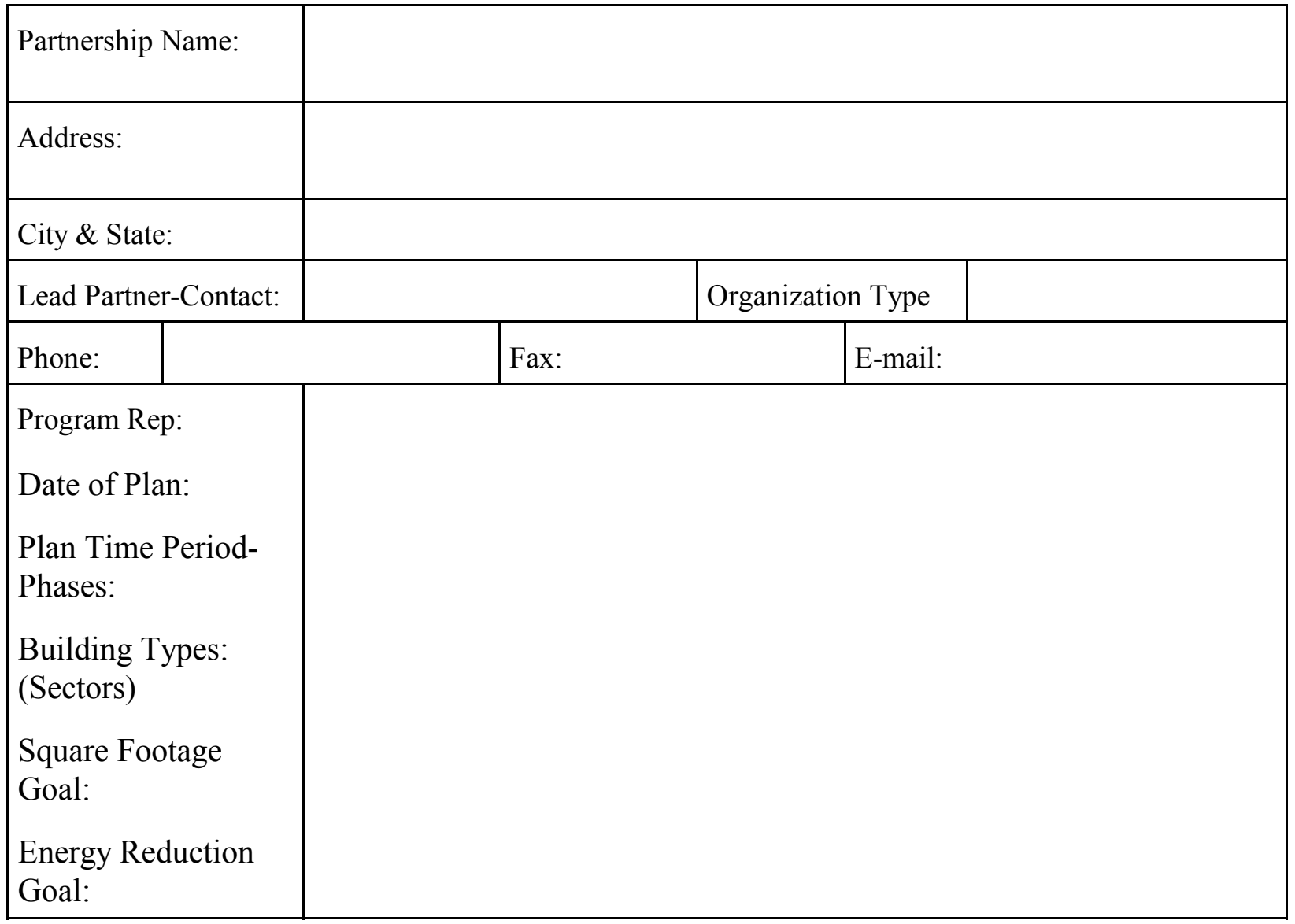

Origination and Lead Partner History

Action Plan Summary 


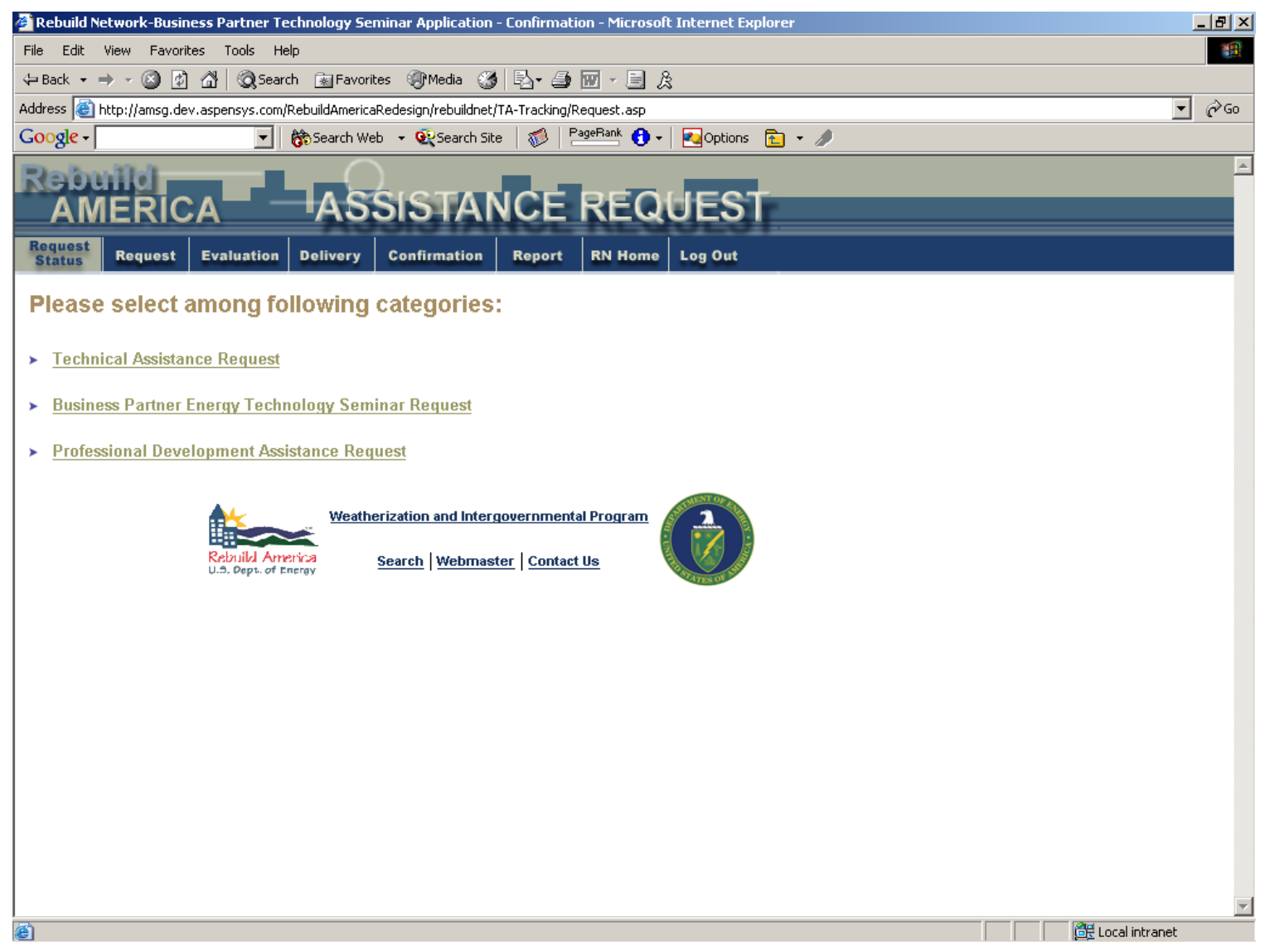

Rebuild Network Project Assistance Center Request Forms http://www.rebuild.org/rebuildnet/TA-Tracking/Request.asp

Project Assistance Center Request Business Partner Technology Seminar RequestProfessional Development Assistance Request- 
Rebuild America Program Manual

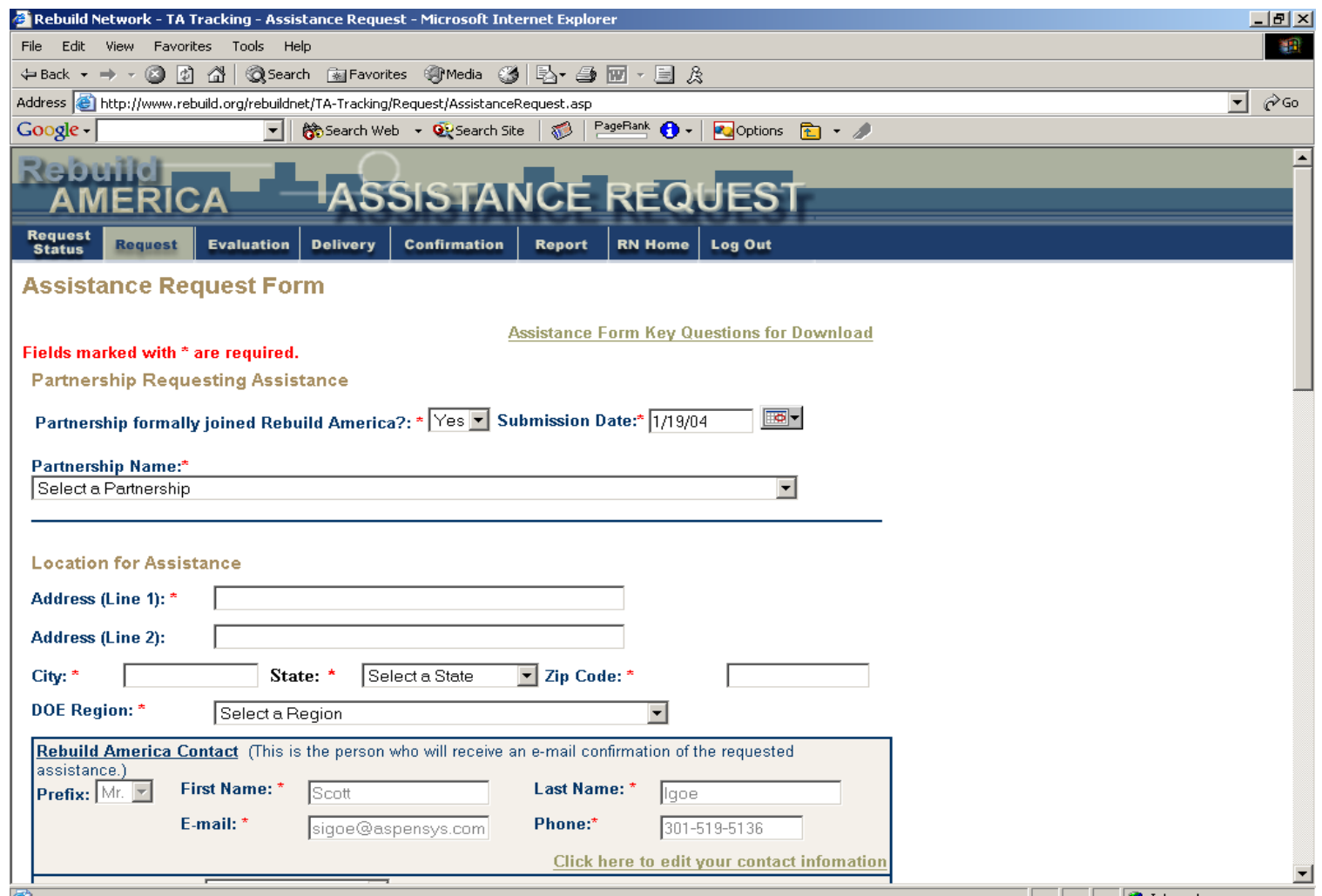

\section{Continued Part 2}

Rebuild Network - TA Tracking - Assistance Request - Microsoft Internet Explorer

File Edit View Favorites Tools Help

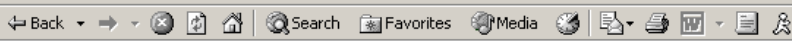

Address 1 http://wwwww.rebuild.org/rebuildnet/TA-Tracking/Request/AssistanceRequest.asp

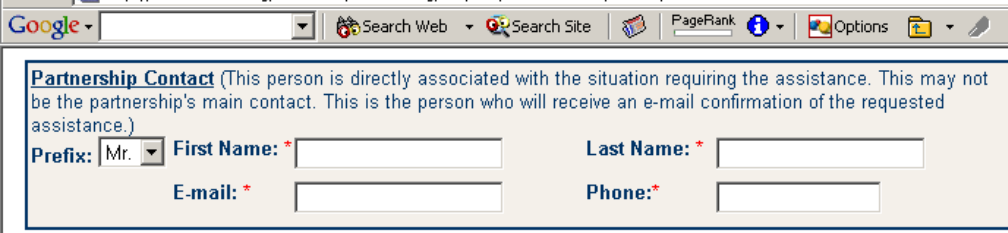

Assistance Request: * (Describe the request with sufficient detail to be clear and understandable. Also address each of the elements in the Assistance Determination Criteria available here.)

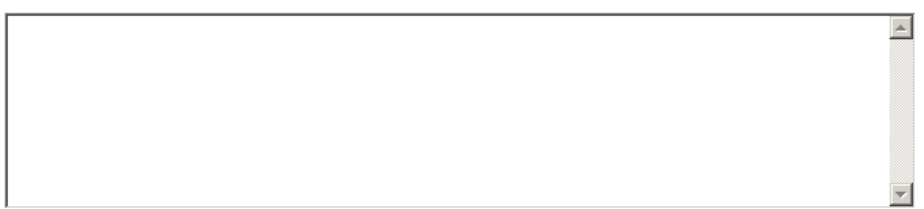

Expected Deliverable: * (Describe what the partnership should expect to receive as a result of the assistance.

Examples include: a technical report, site visit, presentation, participation in a meeting, draft contract language, etc.)

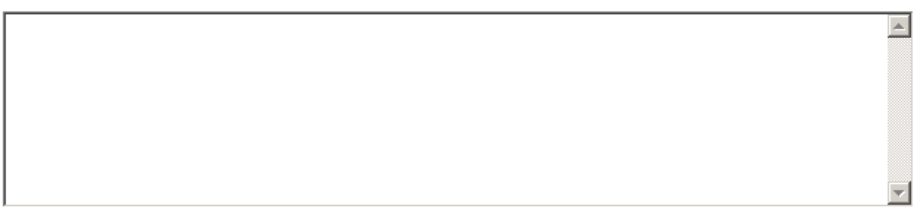

Estimate of Required Effort: * (Estimate the level of effort required by the provider to satisfy the request.)

Select the level of effort

Assistance Due Date: * 


\section{Rebuild America Program Manual}

Part 3

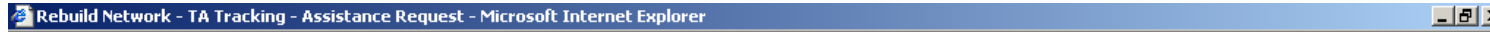

File Edit View Favorites Tools Help

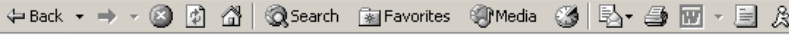

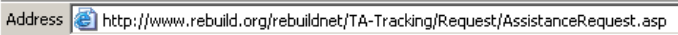

Google -

7 Search Web - Cesearch Site $\mid$ PageRank

a. - 20ptions 눈.

Select the level of effort -

Assistance Due Date: *

Market Sector: * Public and Multi-family Housing K-12 Schools

$\mathrm{K}-12$ Schools
Colleges and Universities

Colleges and Universities

Commercial Buildings

Building Process:

Partnership Formation

ProjectPlanning

No/Low Cost Improvement

Energy Efficiency Retrofit

Major Renovation

Background Information: * (Provide information about the situation that would help the assistance provider to

understand the details and help ensure the appropriate assistance is provided. Items to provide include: building

description, current project status, organizations involved, major milestones, political issues, etc.)

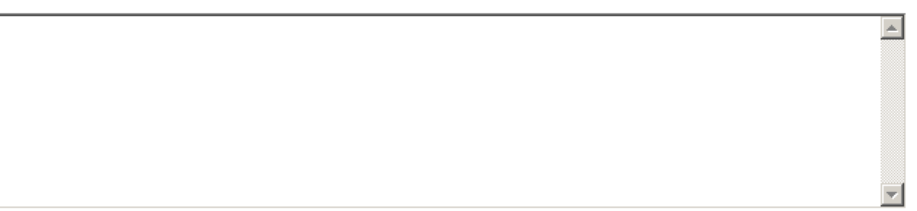

Suggestions for Assistance Delivery and Other Information: * (Provide any other relevant information concerning delivery of assistance. Examples include: information on existing relationships between partnership and assistance provider (i.e. lab personnel), how assistance should be delivered, your desired role, potential follow-up requests, etc.

A

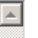




\section{Rebuild America Program Manual}

\section{Business Partner Technology Seminar Request Form}

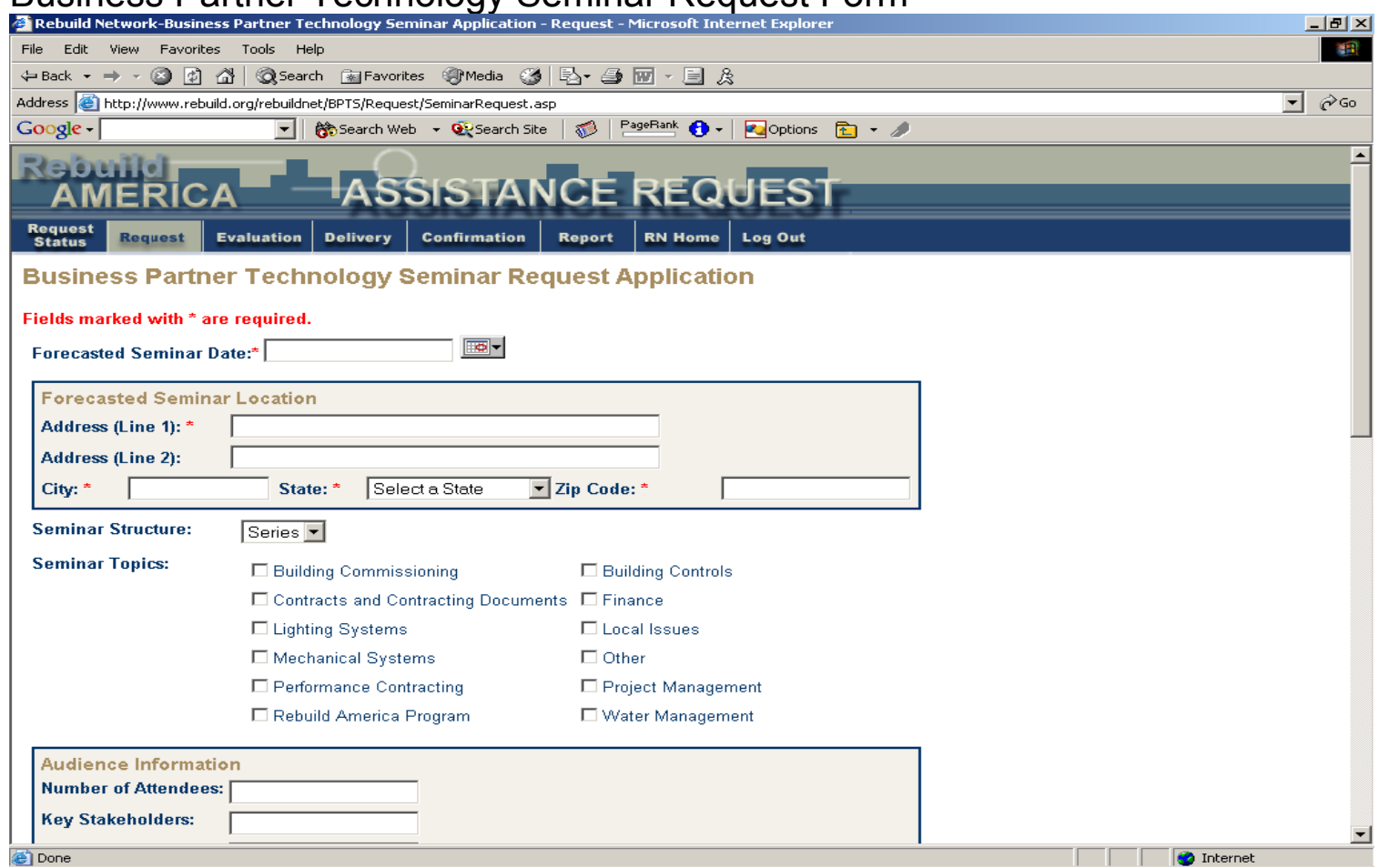

\section{Part 2}

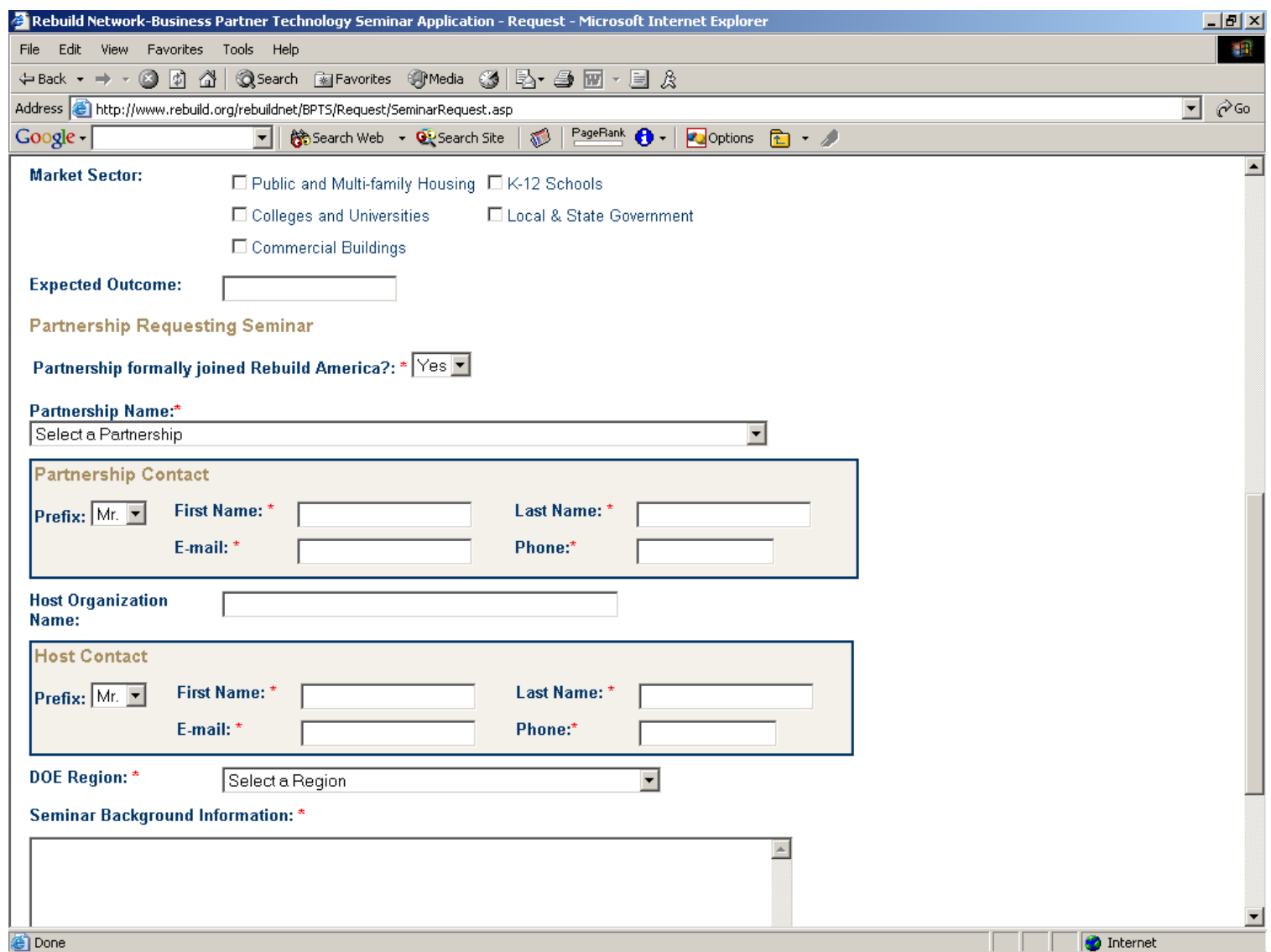




\section{Rebuild America Program Manual}

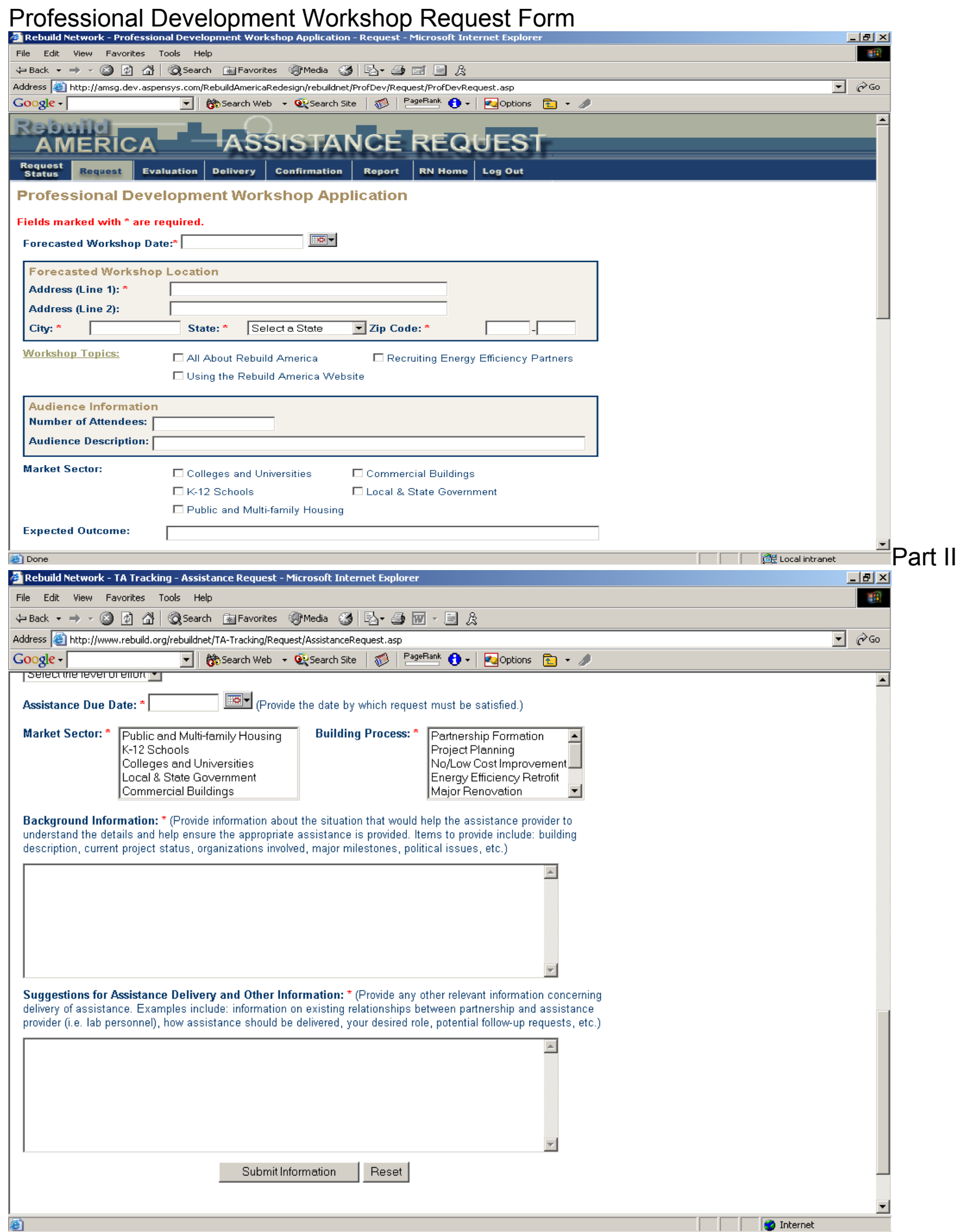

Professional Development Workshop Request Form

Professional Development Workshop Application

Forecasted Workshop Date:

$\Gamma$ All About Rebuild America $「$ Recruiting Energy Efficiency Partners

$\Gamma$ Using the Rebuild America Website

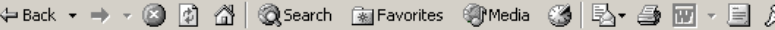

Address 6 http://iwww. rebuild.org/rebuildnet/TA-Tracking/Request/AssistanceRequest. asp

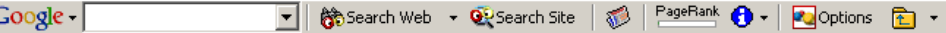

Assistance Due Date: *

K-12 Schools

Colleges and Universities

Local \& State Government

Project Planning

o/Low Cost Improvement

Energy Efficiency Retrofit

Major Renovation

Background Information: * (Provide information about the situation that would help the assistance provider to

understand the details and help ensure the appropriate assistance is provided. Items to provide include: building

description, current project status, organizations involved, major milestones, political issues, etc.) 


\section{Rebuild America Program Manual}

\section{Rebuild Network Solution Center Material Submission Form -}

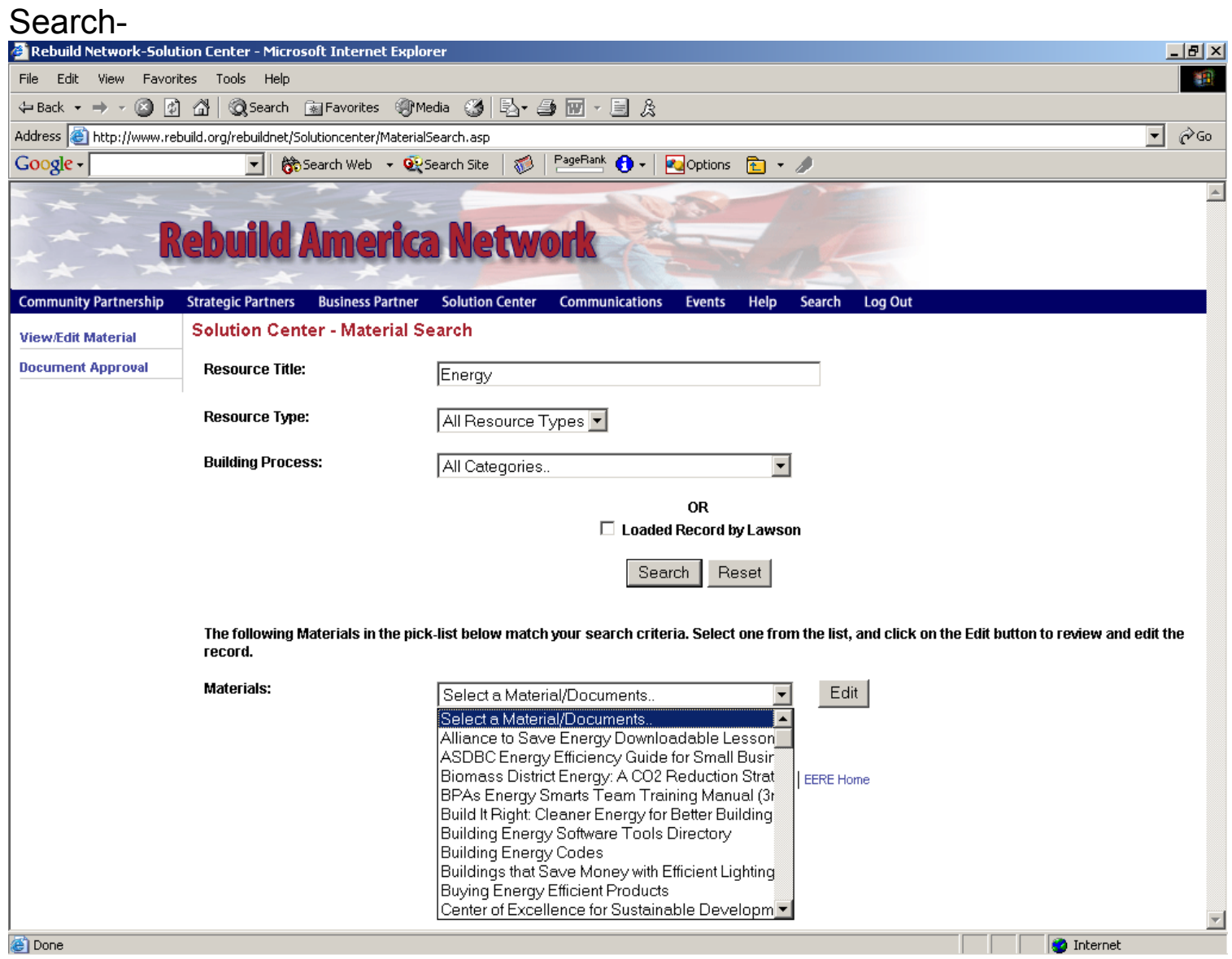

http://www.rebuild.org/rebuildnet/Solutioncenter/materialsearch.asp 


\section{Rebuild America Program Manual}

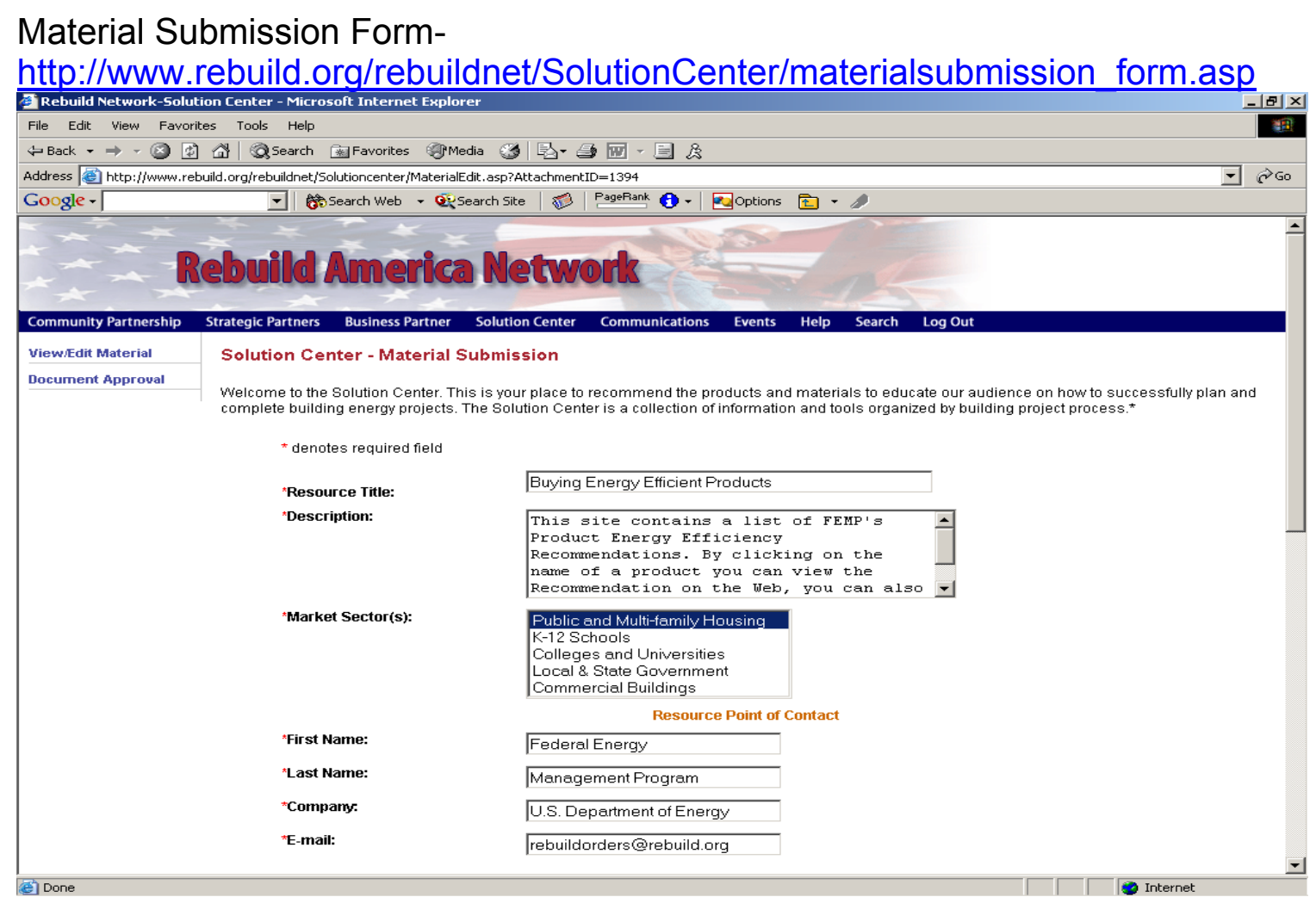

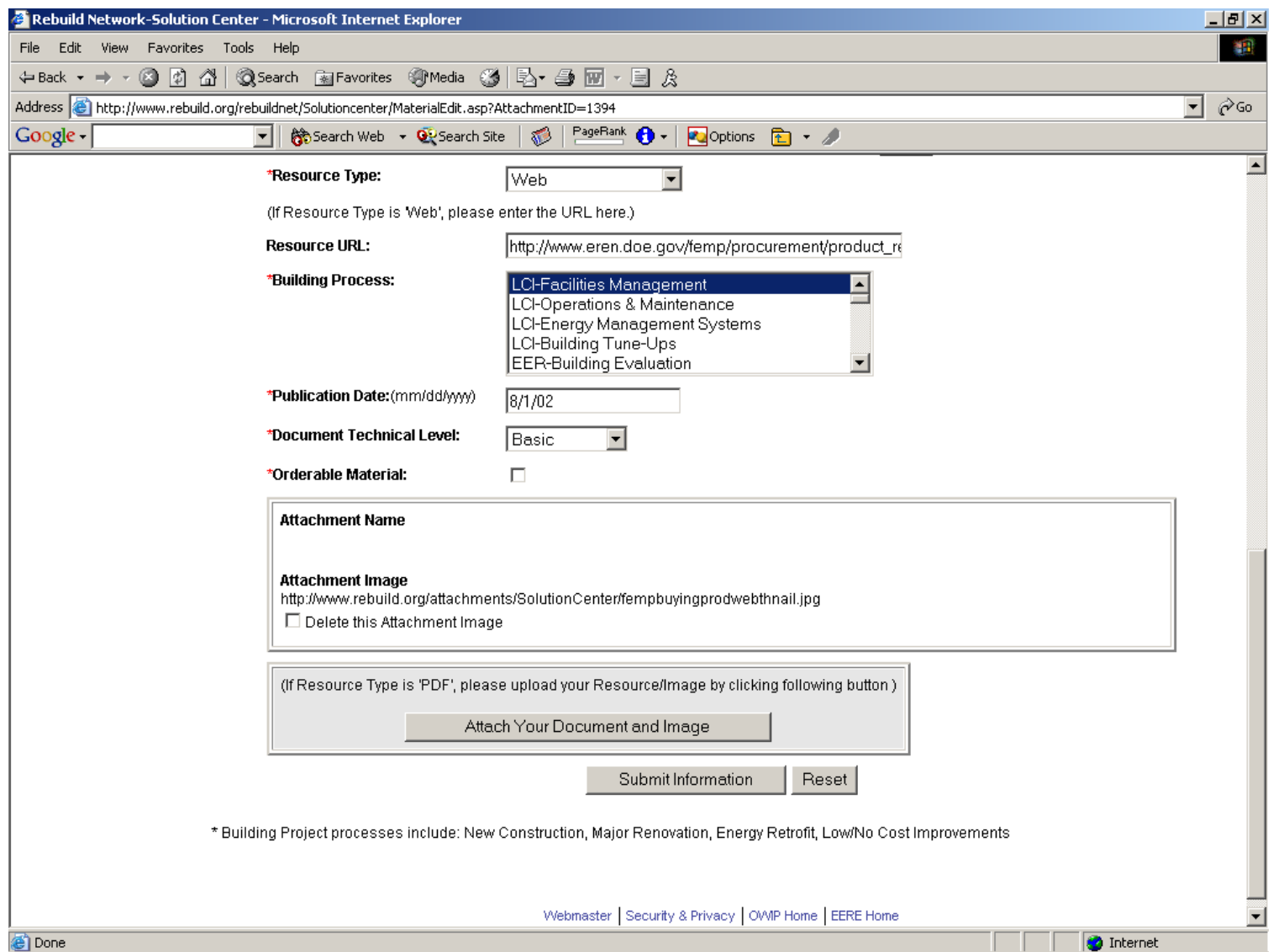




\section{Appendix B.2 Glossary of Terms}

Effective Date: January 2004

\begin{tabular}{|c|c|}
\hline Action Plan & $\begin{array}{l}\text { A plan developed by a partnership, which should clearly define their } \\
\text { goals, milestones and responsibilities. Partnerships are not eligible to } \\
\text { receive Technical Assistance and other services from Rebuild without } \\
\text { first completing their Action Plan. }\end{array}$ \\
\hline Action Plan Guide & $\begin{array}{l}\text { Part of the Rebuild America Guide Series. This Guide is provided to } \\
\text { partnerships to assist them in developing their Action Plan. }\end{array}$ \\
\hline Committed Project & $\begin{array}{l}\text { Projects that have identified buildings for retrofit or renovation within a } \\
\text { period of time. }\end{array}$ \\
\hline Completed Project & $\begin{array}{l}\text { Projects where the planned retrofit or renovation activities have been } \\
\text { completed and the new systems are fully operational. }\end{array}$ \\
\hline $\begin{array}{l}\text { Customer Service (CS) } \\
\text { Team }\end{array}$ & $\begin{array}{l}\text { A team within the Rebuild National Program whose objective is to } \\
\text { recruit, develop, and move partnerships to action and success. For } \\
\text { more detail, please see Section } 8.2 \text { "Program Roles \& } \\
\text { Responsibilities." }\end{array}$ \\
\hline DOE & Department of Energy \\
\hline EREC & $\begin{array}{l}\text { Energy Efficiency and Renewable Energy Clearinghouse - The } \\
\text { Clearinghouse specializes in the dissemination of energy efficiency } \\
\text { (EE) and renewable energy (RE) information. }\end{array}$ \\
\hline EERE & Office of Energy Efficiency and Renewable Energy \\
\hline ESCO & Energy Service Company \\
\hline EZ/EC & Empower Zone/Enterprise Community etc. \\
\hline $\begin{array}{l}\text { Program Representative } \\
\text { (Rep) }\end{array}$ & $\begin{array}{l}\text { A Rep is the primary and continuing point of contact between } \\
\text { individual partnerships and DOE. For roles and responsibilities of a } \\
\text { Rep, please see section A.2 "Program Roles and Responsibilities." }\end{array}$ \\
\hline Prospective Partnership & $\begin{array}{l}\text { A community or organization with interest in Rebuild and has a high } \\
\text { probability of becoming a successful Rebuild partnership. }\end{array}$ \\
\hline PUC & Public Utility Commission \\
\hline ROI & Return on Investment \\
\hline RO & Regional Office (DOE) \\
\hline $\begin{array}{l}\text { Regional Team Leader } \\
\text { (TL) }\end{array}$ & $\begin{array}{l}\text { Regional office staff members responsible for coordinating and } \\
\text { enhancing staff and resources within their region to meet } \\
\text { Partnership's needs as well as Rebuild's goals. There will be a Team } \\
\text { Leader designated for each of the six DOE regions. For roles and } \\
\text { responsibilities of a Team Leader, please see section A.2 "Program } \\
\text { Roles and Responsibilities." }\end{array}$ \\
\hline $\begin{array}{l}\text { Self-sufficient } \\
\text { partnership }\end{array}$ & A partnership that is able to maintain itself without outside assistance. \\
\hline
\end{tabular}




\begin{tabular}{|c|c|}
\hline SEO & State Energy Office \\
\hline Technical Assistance & $\begin{array}{l}\text { Technical assistance is interim assistance in the form of products and } \\
\text { services provided to partnerships when unavailable locally. }\end{array}$ \\
\hline Action Plan & $\begin{array}{l}\text { A plan developed by a partnership, which should clearly define their } \\
\text { goals, milestones and responsibilities. Partnerships are not eligible to } \\
\text { receive Technical Assistance and other services from Rebuild without } \\
\text { first completing their Action Plan. }\end{array}$ \\
\hline Action Plan Guide & $\begin{array}{l}\text { Part of the Rebuild America Guide Series. This Guide is provided to } \\
\text { partnerships to assist them in developing their Action Plan. }\end{array}$ \\
\hline BTS & $\begin{array}{l}\text { Office of Building Technology State and Community Programs. An } \\
\text { office of the U.S. Department of Energy (DOE). }\end{array}$ \\
\hline $\begin{array}{l}\text { Customer Service (CS) } \\
\text { Team }\end{array}$ & $\begin{array}{l}\text { A team within the Rebuild National Program whose objective is to } \\
\text { recruit, develop, and move partnerships to action and success. For } \\
\text { more detail, please see Section } 8.2 \text { "Program Roles \& } \\
\text { Responsibilities." }\end{array}$ \\
\hline DOE & Department of Energy \\
\hline EREC & $\begin{array}{l}\text { Energy Efficiency and Renewable Energy Clearinghouse - The } \\
\text { Clearinghouse specializes in the dissemination of energy efficiency } \\
(\mathrm{EE}) \text { and renewable energy (RE) information. }\end{array}$ \\
\hline EERE & Office of Energy Efficiency and Renewable Energy \\
\hline ESCO & Energy Service Company \\
\hline EZ/EC & Empower Zone/Enterprise Community etc. \\
\hline $\begin{array}{l}\text { Program Representative } \\
\text { (Rep) }\end{array}$ & $\begin{array}{l}\text { A Rep is the primary and continuing point of contact between } \\
\text { individual partnerships and DOE. For roles and responsibilities of a } \\
\text { Rep, please see section A.2 "Program Roles and Responsibilities." }\end{array}$ \\
\hline Prospective Partnership & $\begin{array}{l}\text { A community or organization with interest in Rebuild and has a high } \\
\text { probability of becoming a successful Rebuild partnership. }\end{array}$ \\
\hline PUC & Public Utility Commission \\
\hline ROI & Return on Investment \\
\hline RO & Regional Office (DOE) \\
\hline $\begin{array}{l}\text { Regional Team Leader } \\
\text { (TL) }\end{array}$ & $\begin{array}{l}\text { Regional office staff members responsible for coordinating and } \\
\text { enhancing staff and resources within their region to meet } \\
\text { Partnership's needs as well as Rebuild's goals. There will be a Team } \\
\text { Leader designated for each of the six DOE regions. For roles and } \\
\text { responsibilities of a Team Leader, please see section A.2 "Program } \\
\text { Roles and Responsibilities." }\end{array}$ \\
\hline $\begin{array}{l}\text { Self-sufficient } \\
\text { partnership }\end{array}$ & A partnership that is able to maintain itself without outside assistance. \\
\hline SEO & State Energy Office \\
\hline Technical As & $\begin{array}{l}\text { Technical assistance is interim assistance in the form of products and } \\
\text { services provided to partnerships when unavailable locally. }\end{array}$ \\
\hline
\end{tabular}




\section{APPENDIX C}

Rebuild America 2004:

Program Accomplishments and Analysis 


\section{Rebuild America 2004}

Program Accomplishments and

Analysis

Seattle, WA

November 9, 2004 


\section{KEY METRICS}

\section{Program and Project Data Analysis}




\section{Key Metrics: Square Footage Growth}

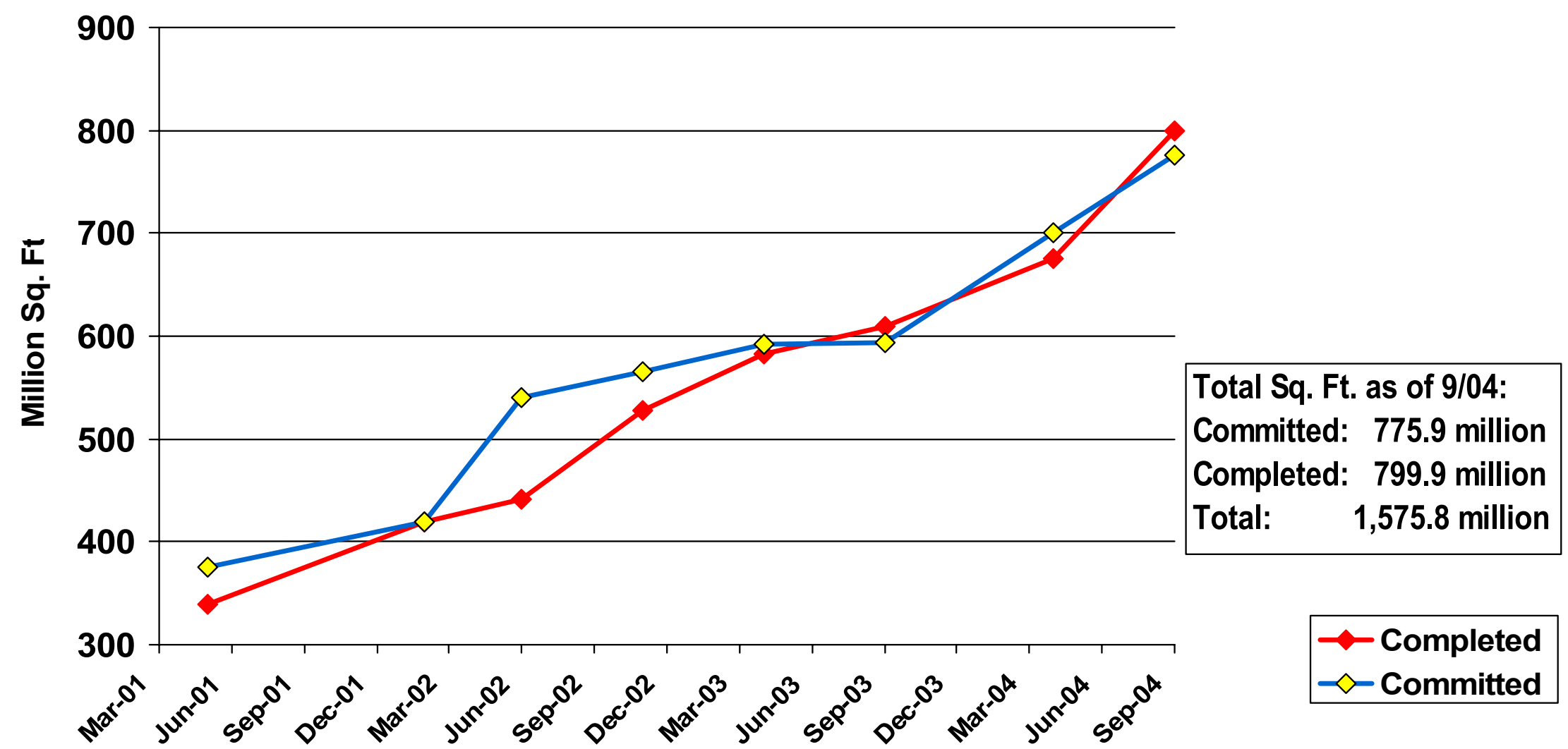




\section{Key Metrics: Project Growth}

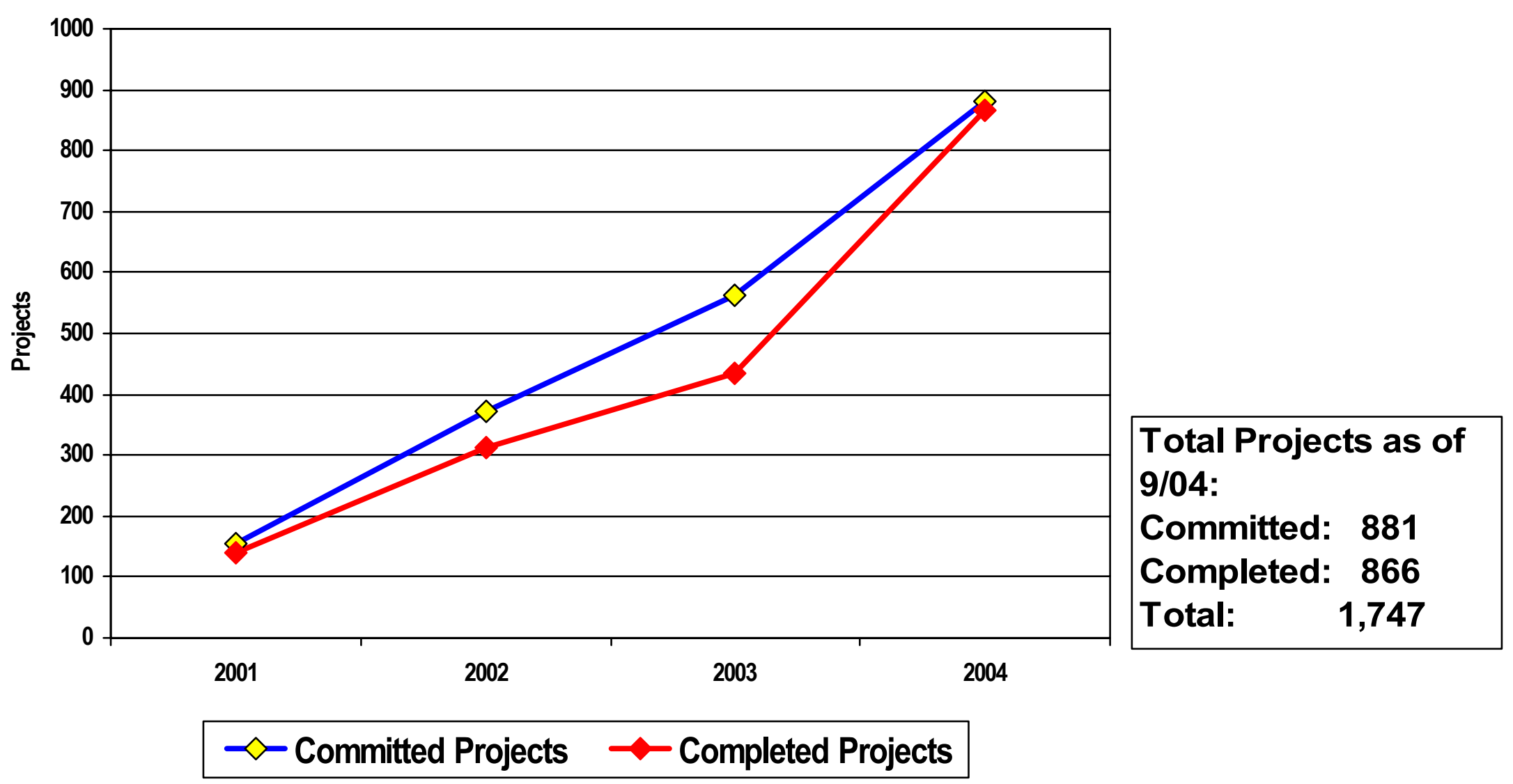




\section{Annual Project Additions: Average Project Size}

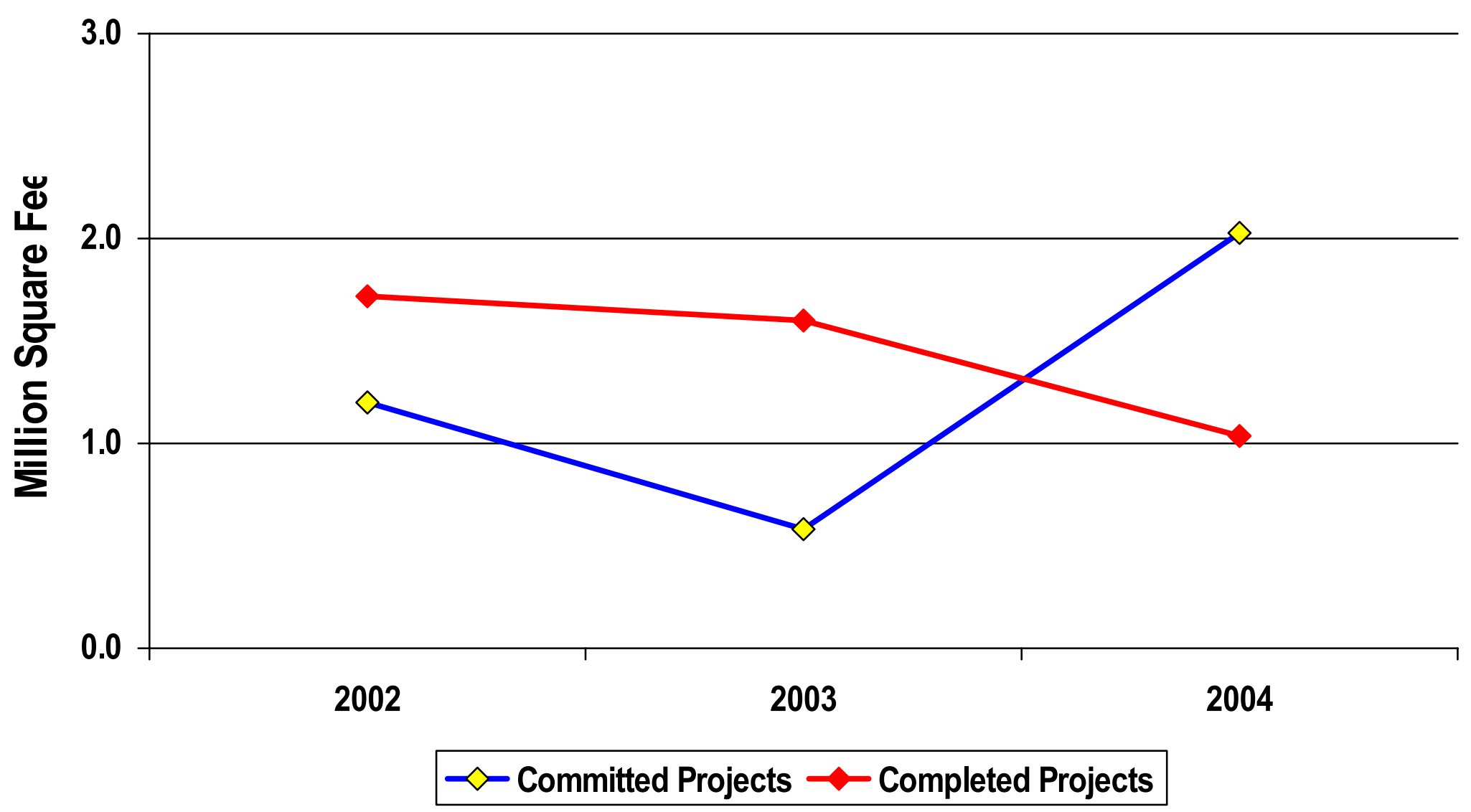




\section{Key Metrics: Growth by Market Sector - Committed}

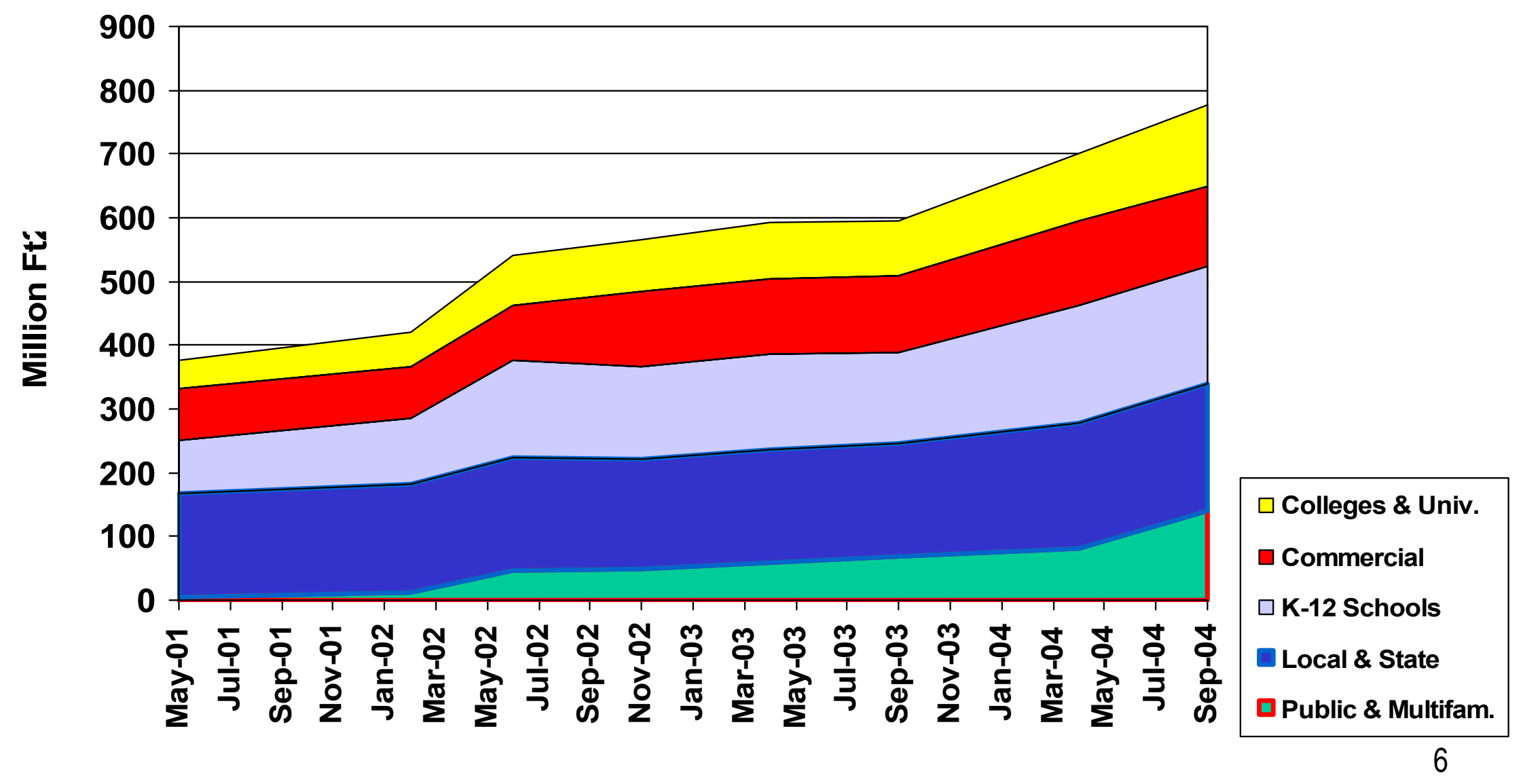




\section{Key Metrics: Growth by Market Sector - Completed}

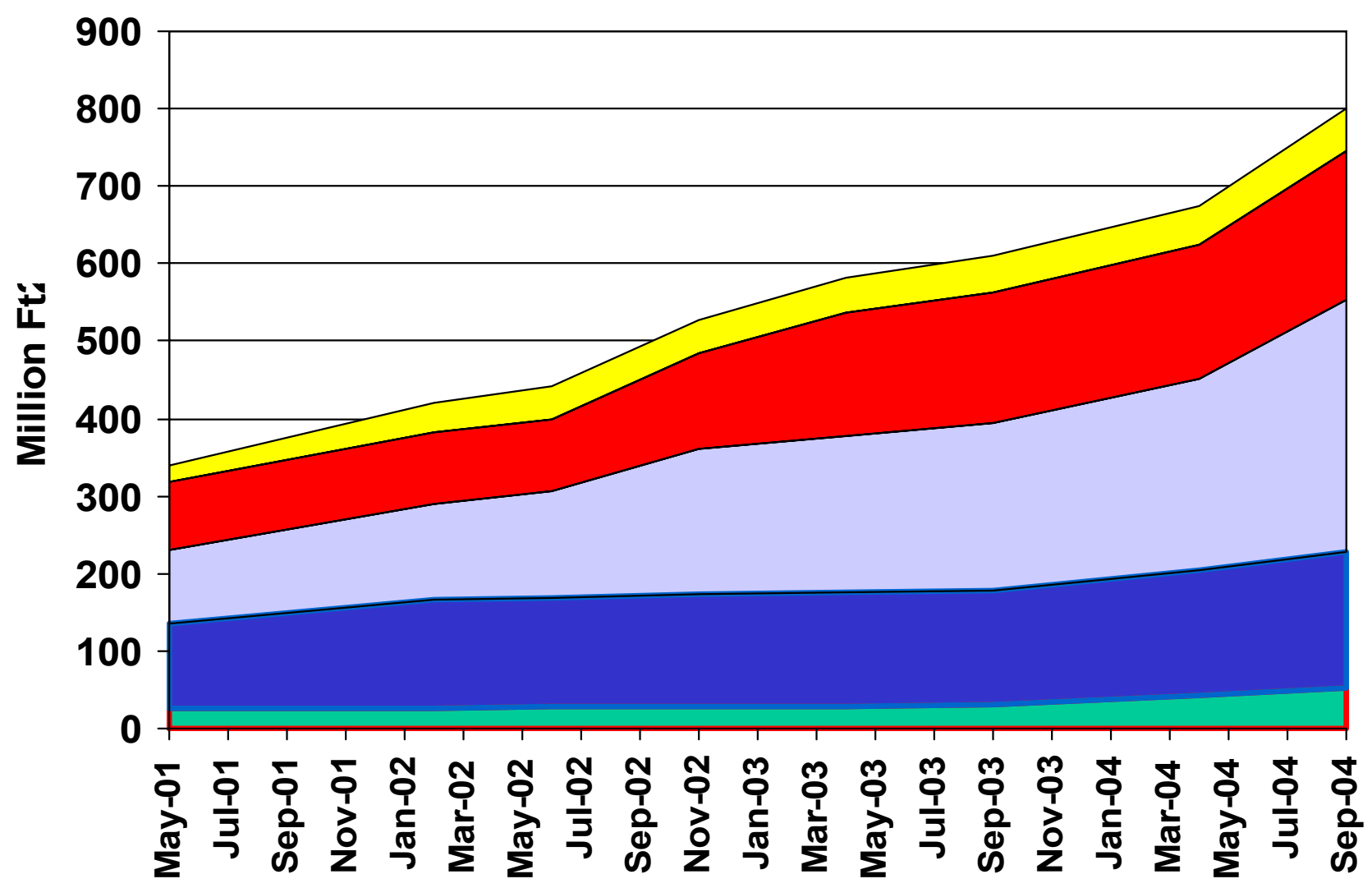

$\square$ Colleges \& Univ.

$\square$ Commercial $\square$ K-12 Schools Local \& State $\square$ Public \& Multifam. 


\section{Program Goal Achievement: Actual and Trend for Committed and Completed Separately}
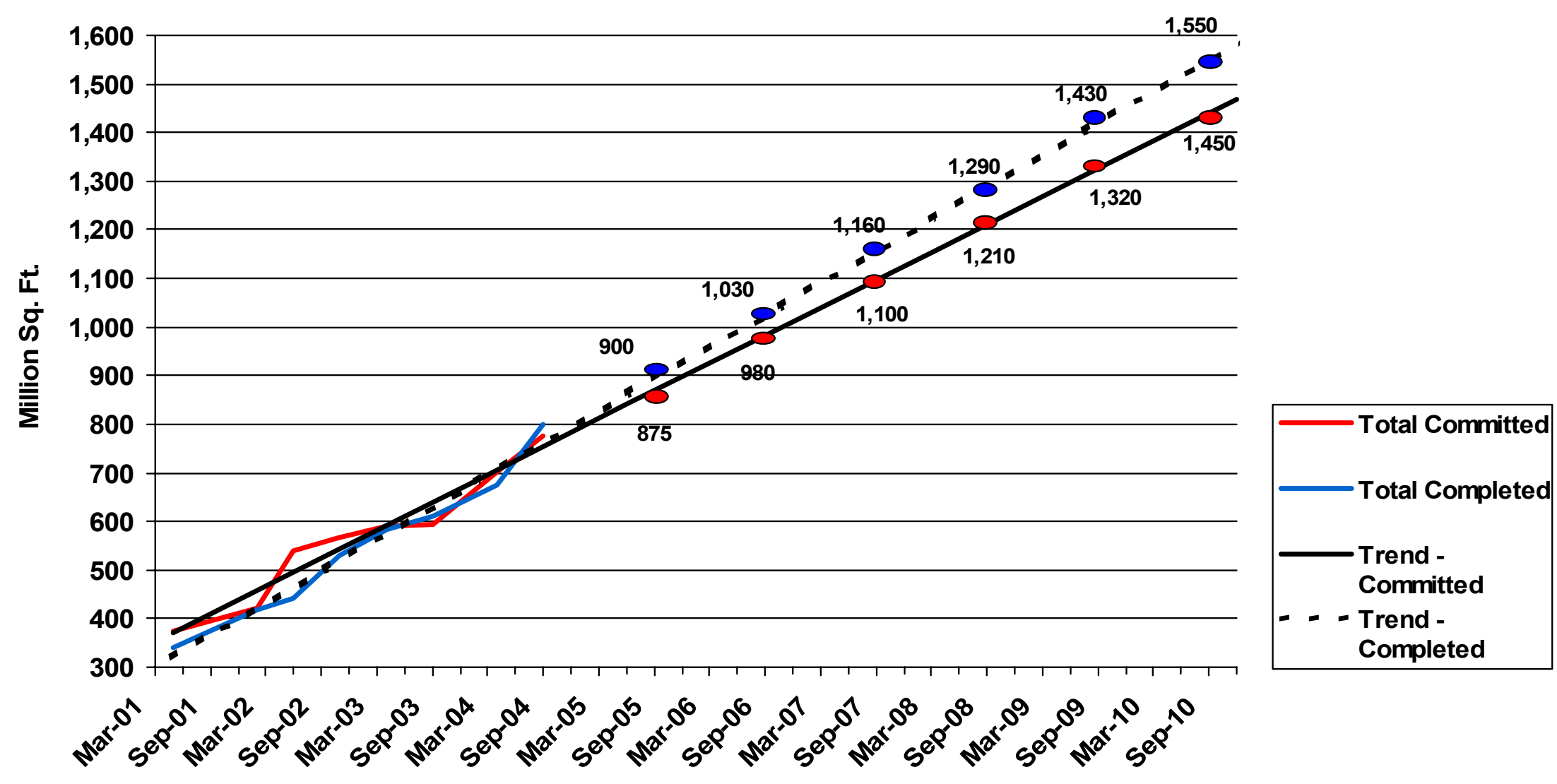


\section{Program Goal Achievement: Actual and Trend for Committed and Completed}
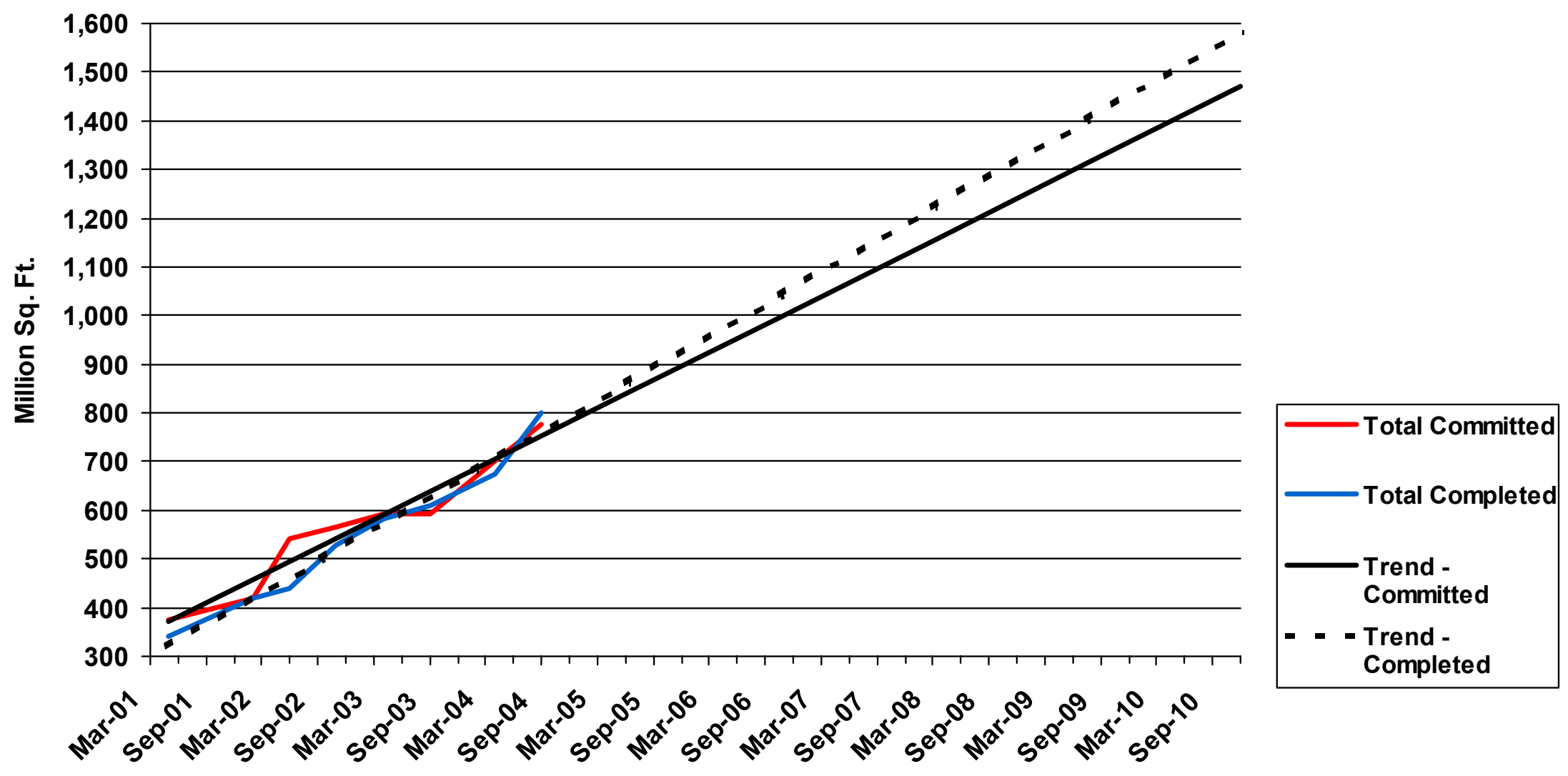


\section{Program Goal Achievement: Actual and Trend for Committed plus Completed}

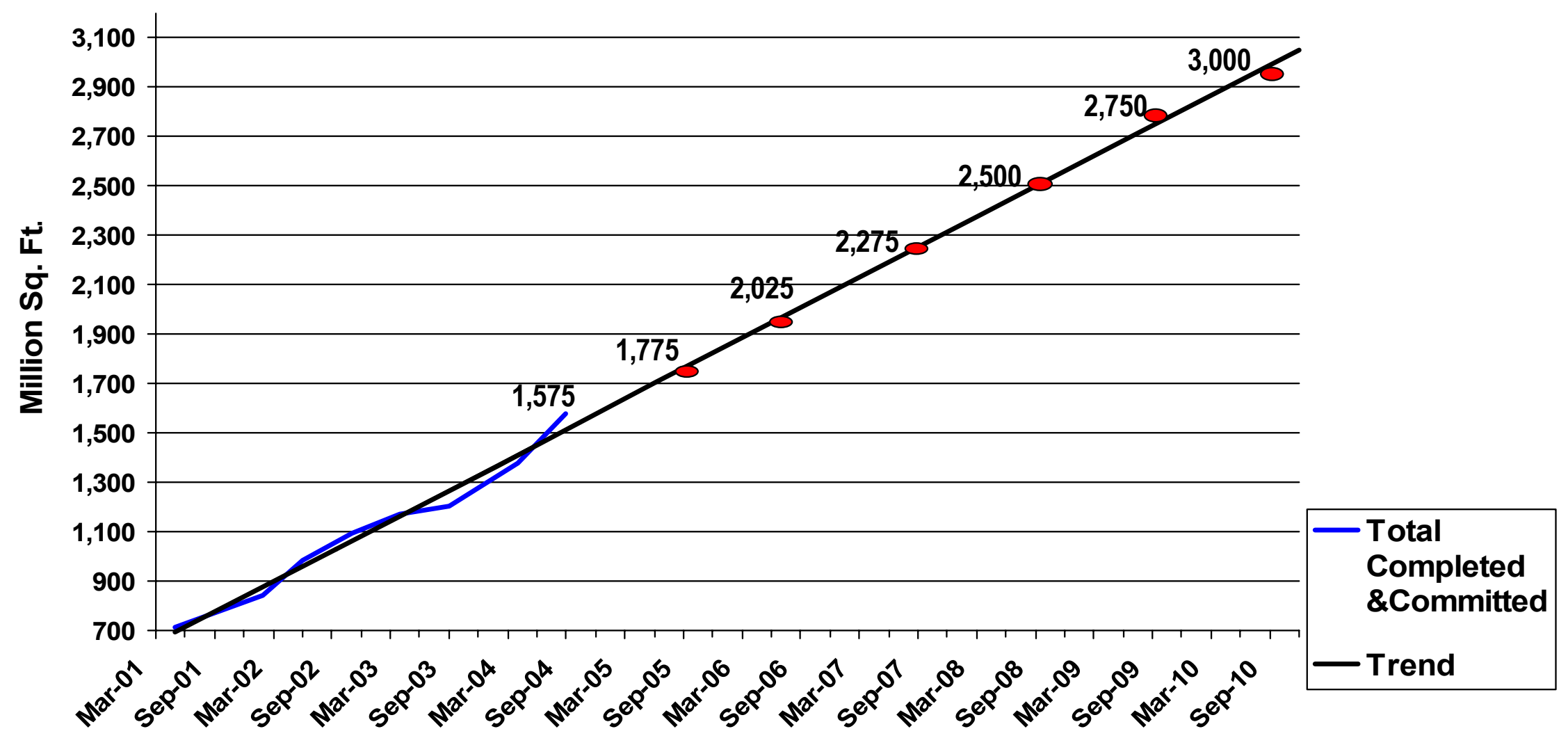




\section{Program Goal Achievement: Actual 2004 vs. Trend from 2001-2003 Actual}

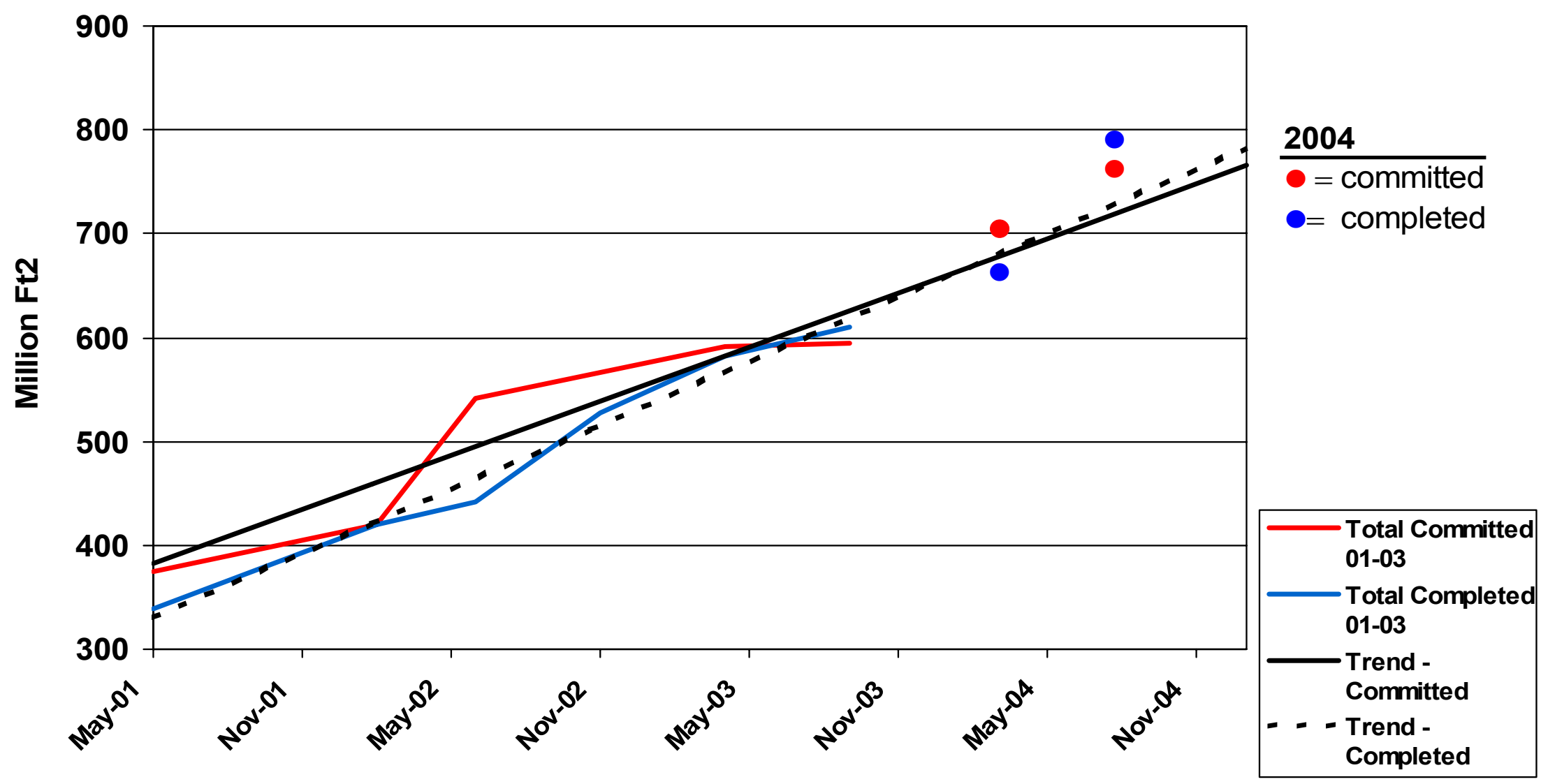




\section{Annual Partnership Growth: Actual and Forecast}

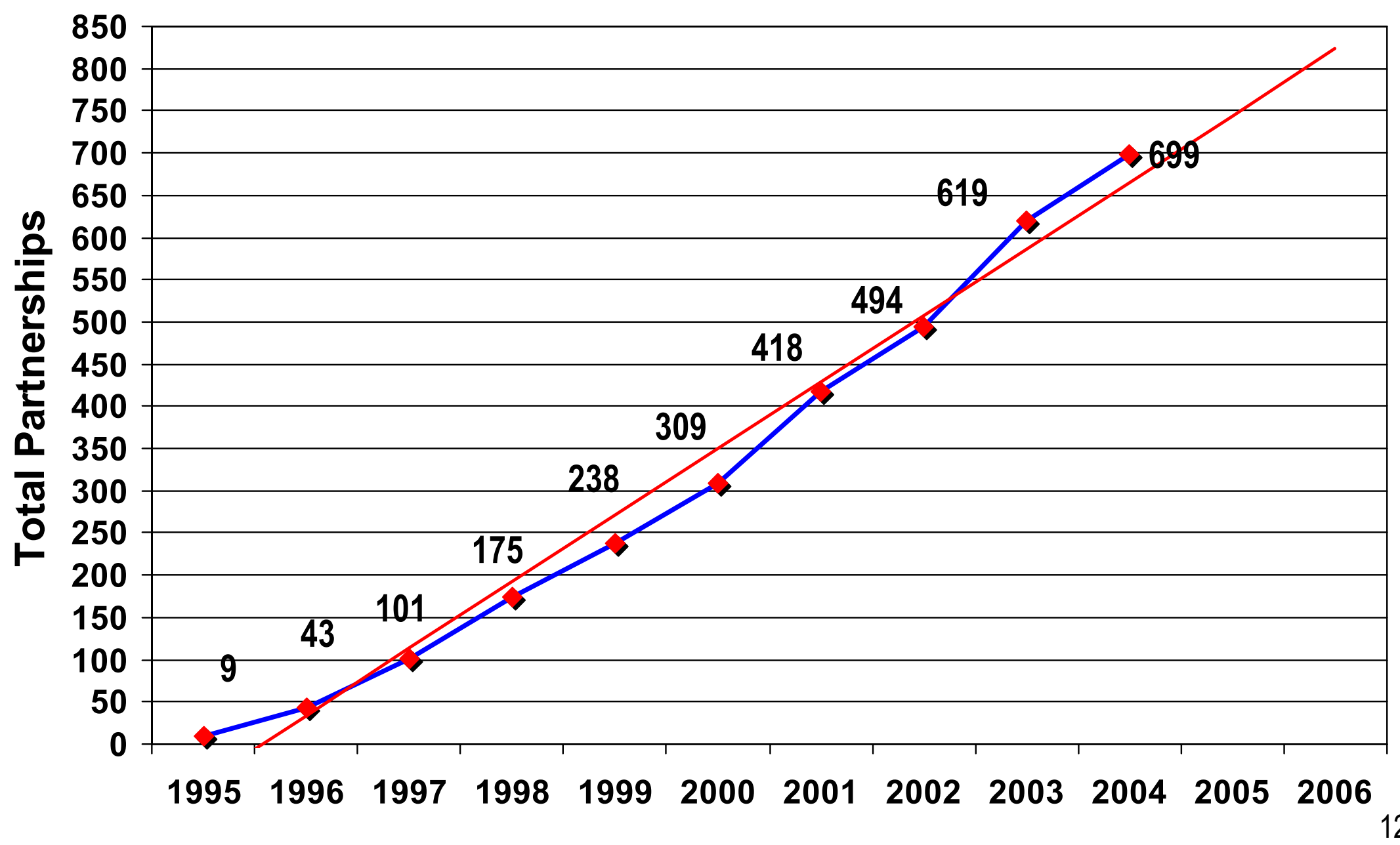




\section{Current Partnership Activity}

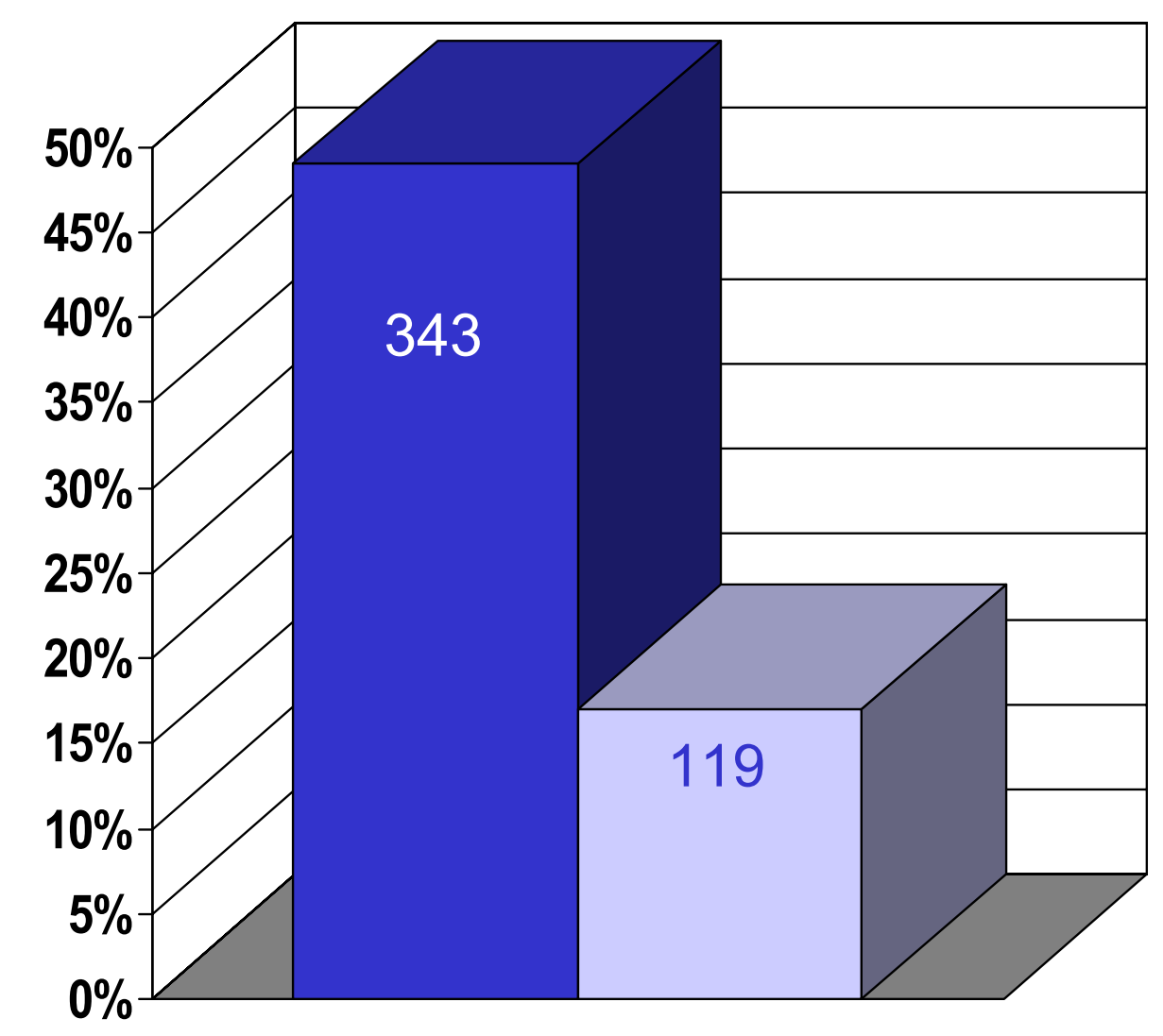

$\square$ Partnerships with Projects

$\square$ Partnerships with Completed Ft2 


\section{Current Partnership Activity: Current and Completed Detail}
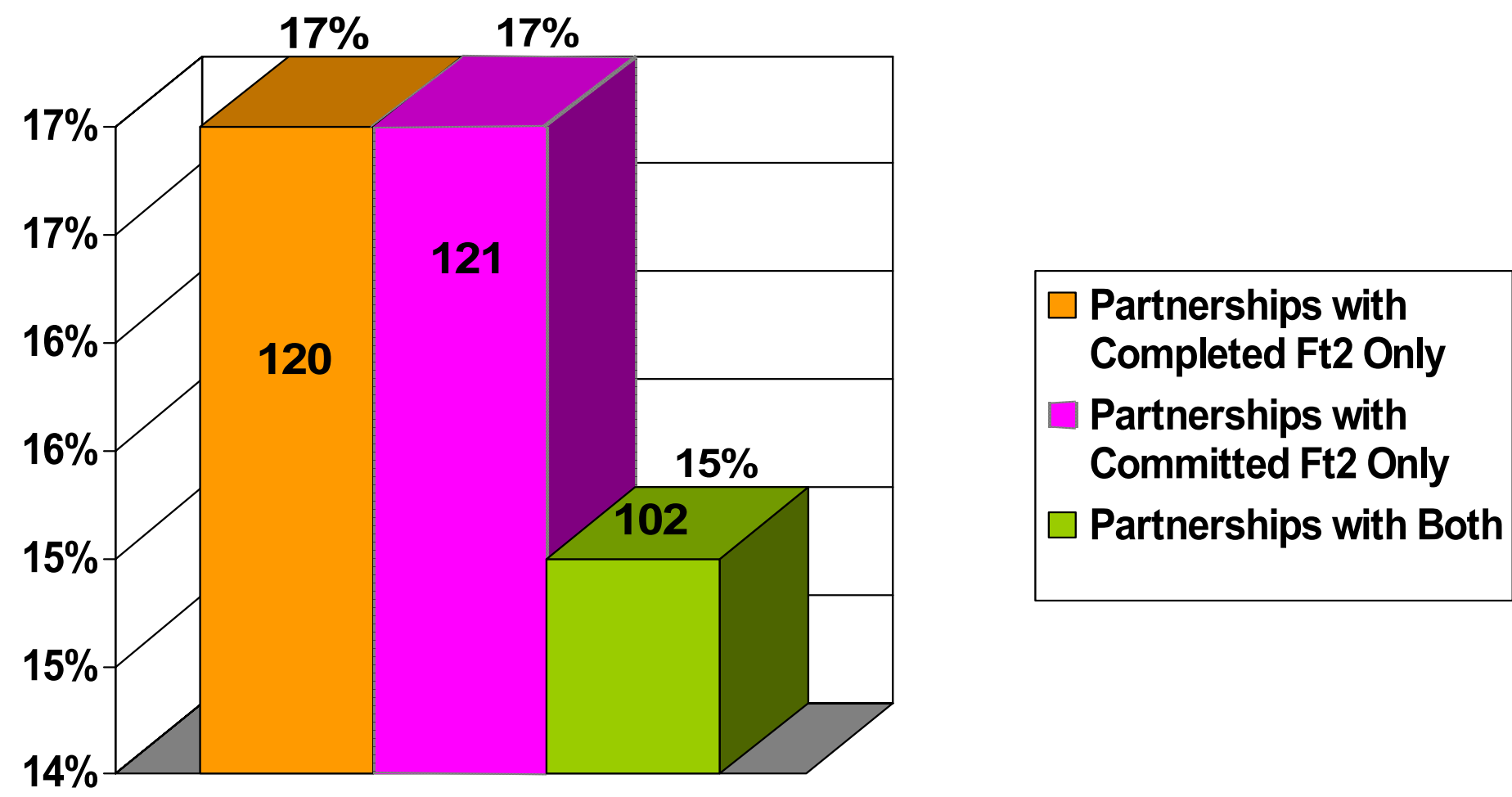

$\square$ Partnerships with Both 


\section{Annual Partnership Growth: Regional Analysis}

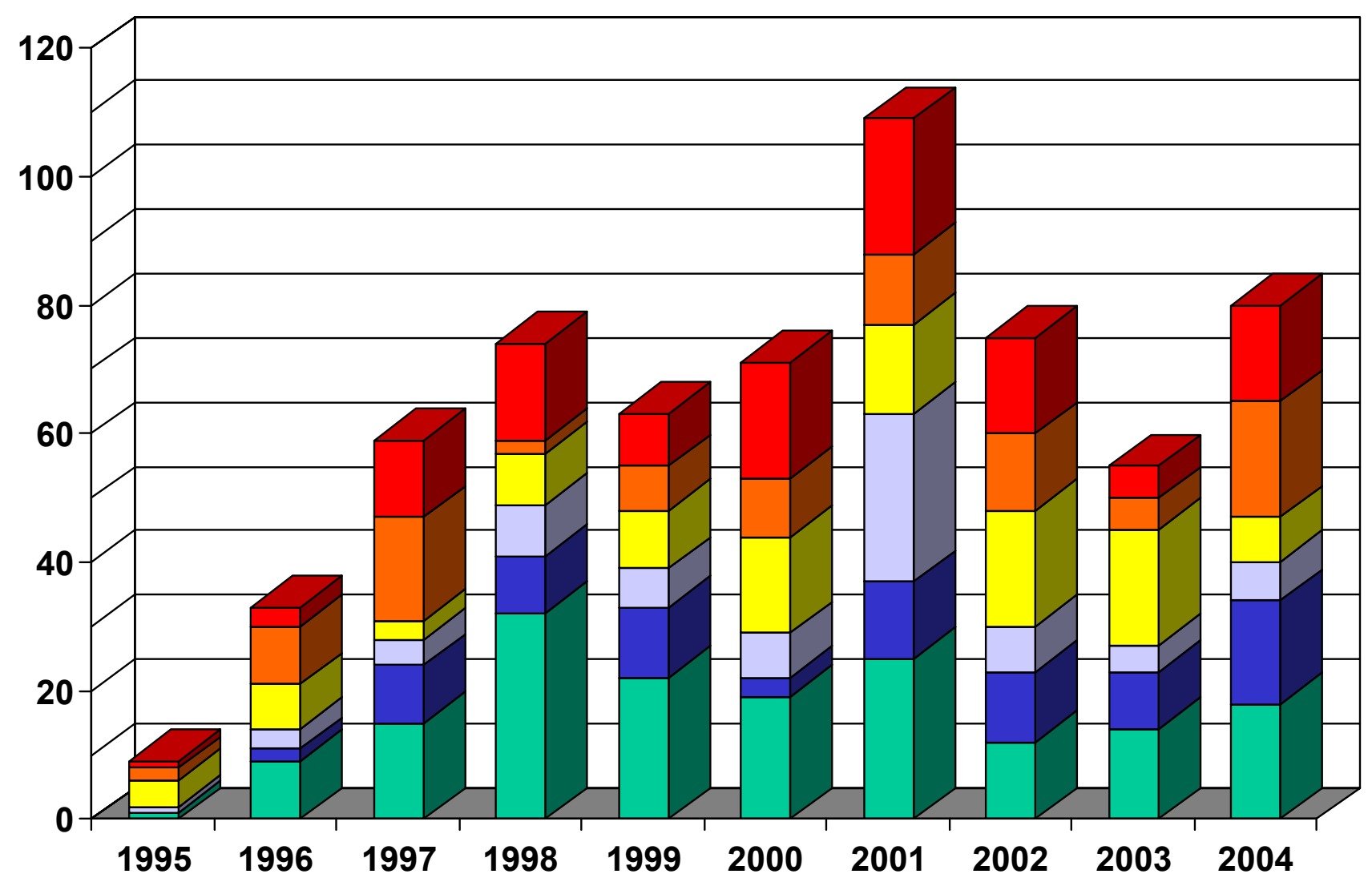

$\square$ Southeast $\square$ Northeast

$\square$ Midwest

$\square$ Central $\square$ Mid-Atlantic $\square$ Western 


\section{Regional Partnership Comparison: Total vs. Projects Reported}

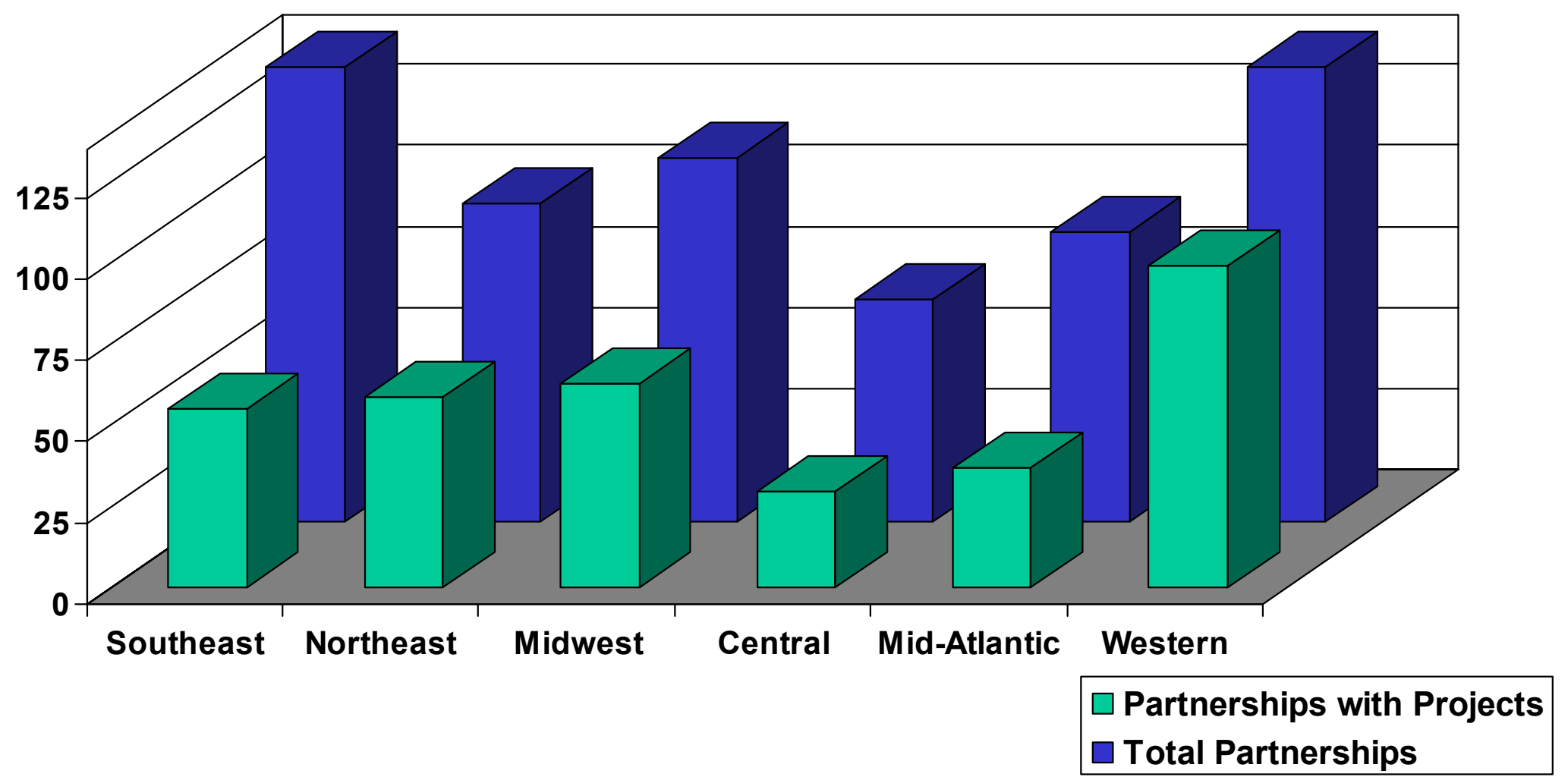




\section{Average Partnership Square Footage by Region}

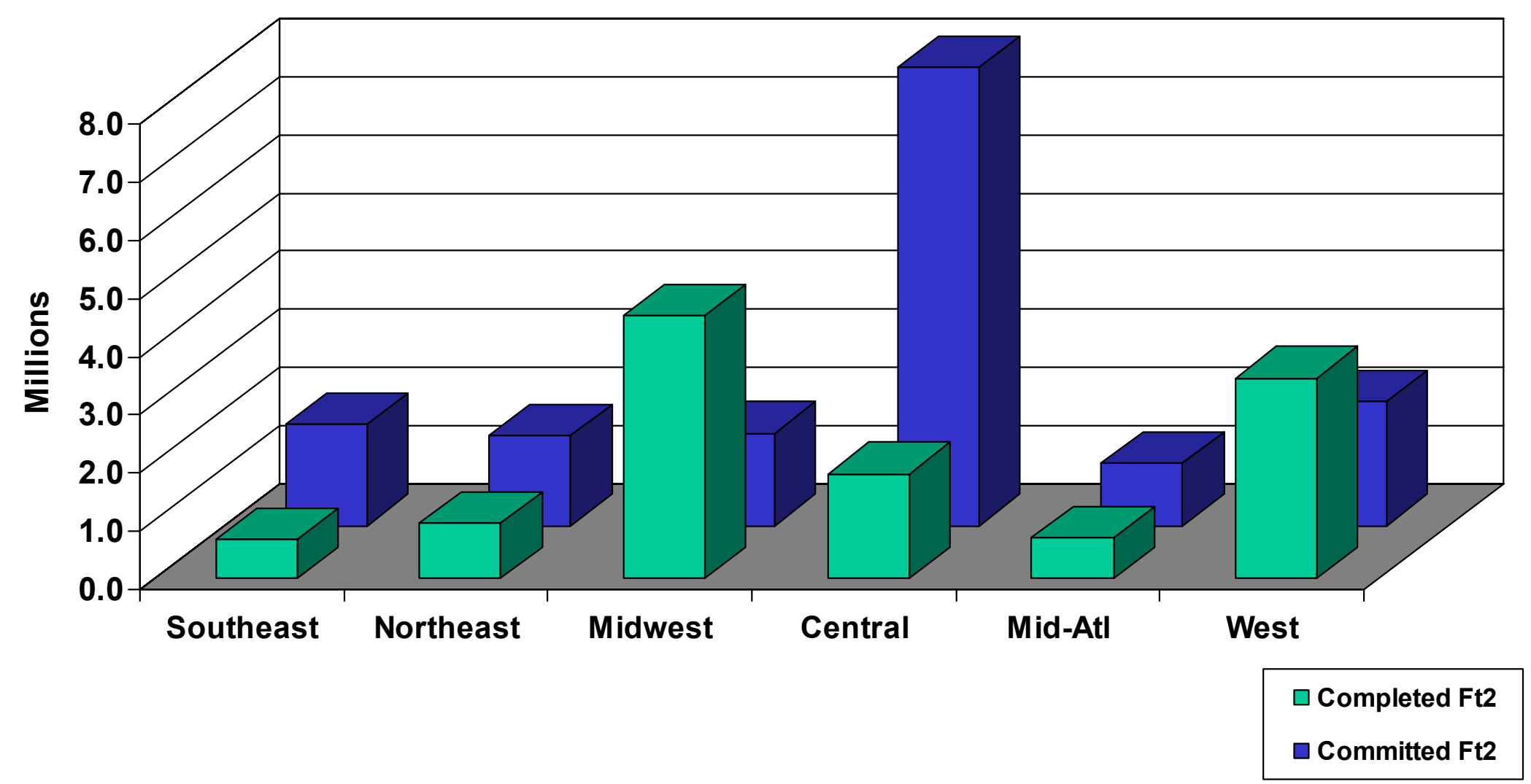




\section{Square Footage by Region}

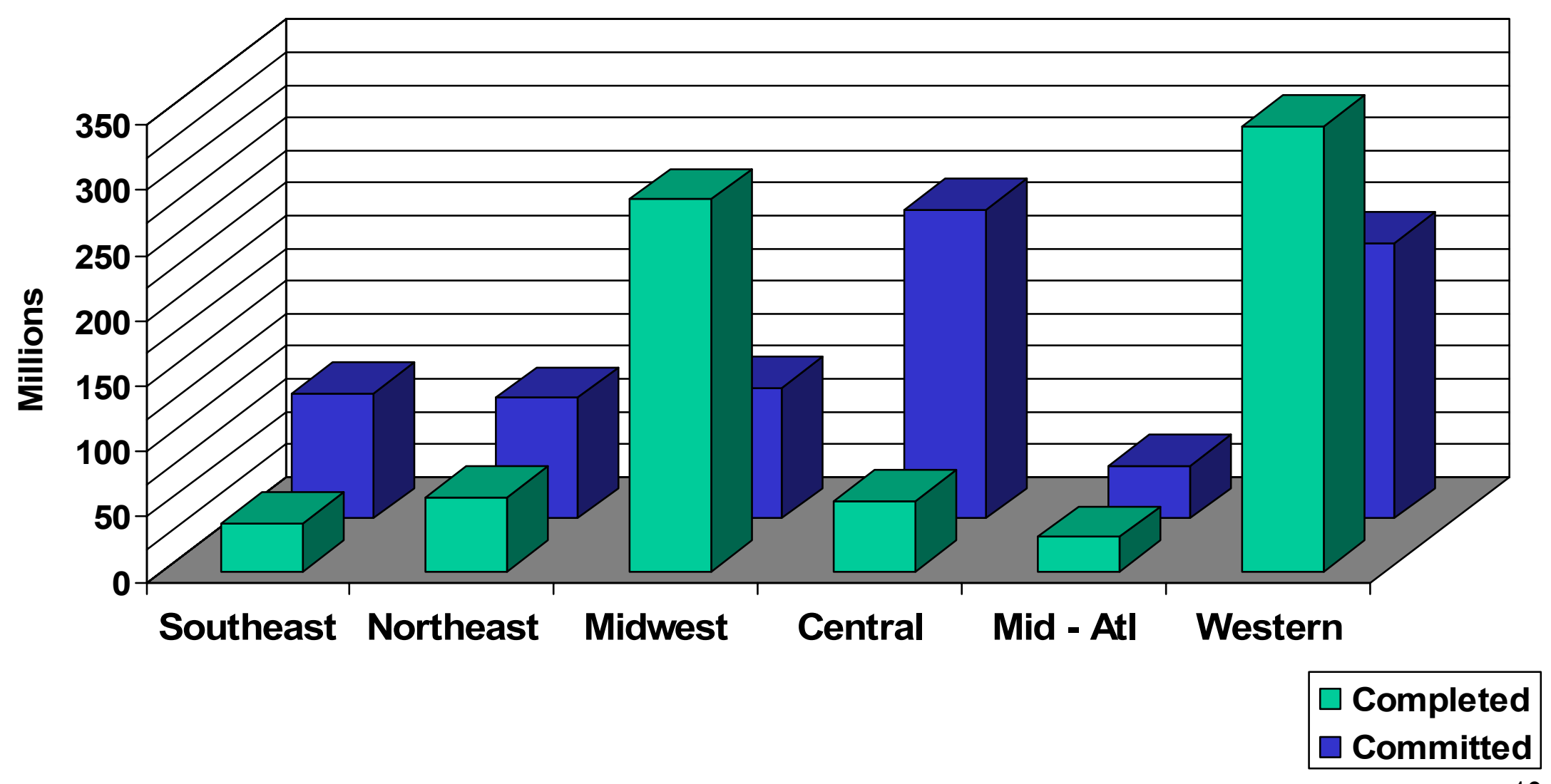




\section{Projects by Region: Committed or Completed}

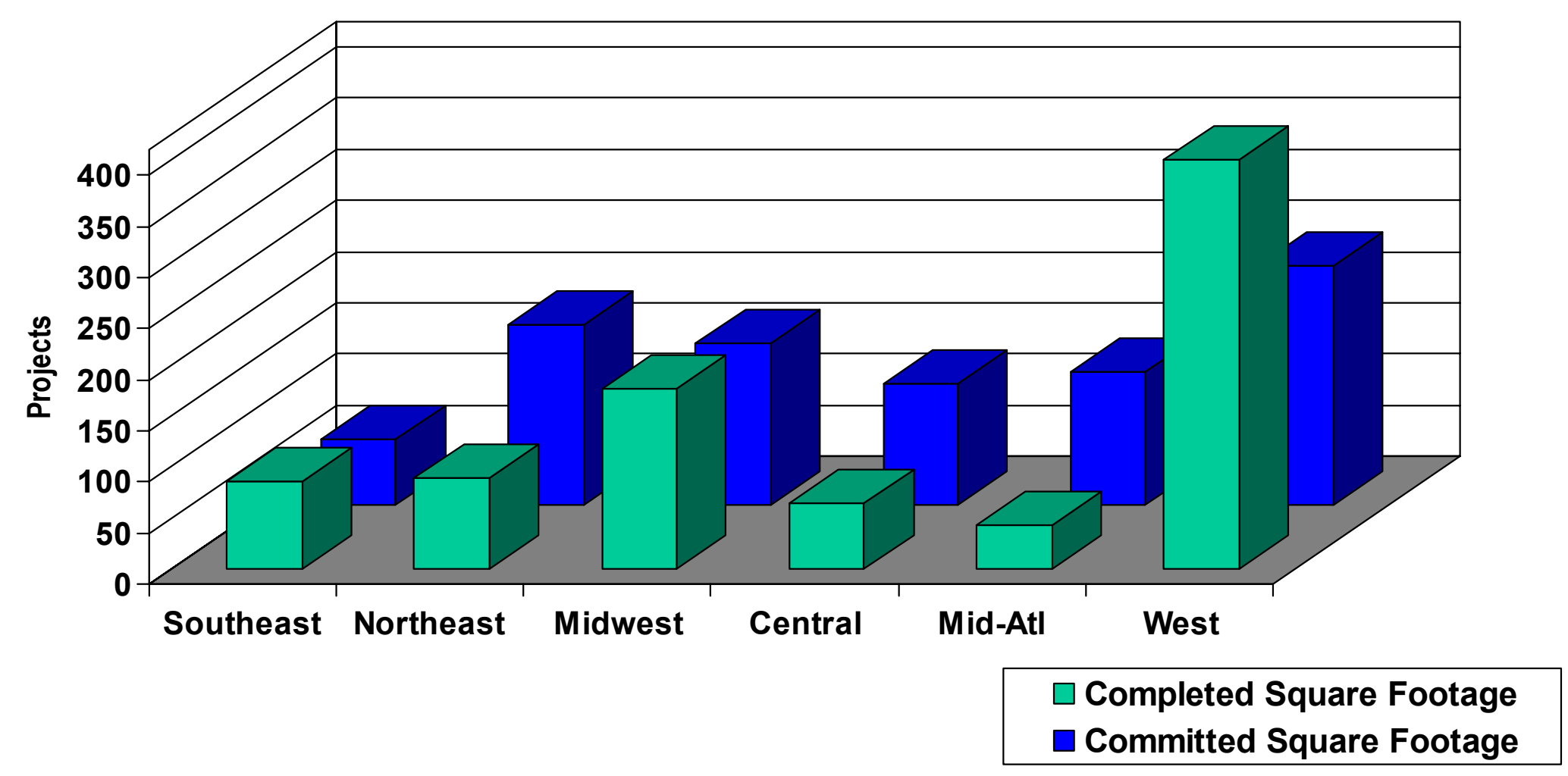




\section{Average Project Square Footage by Region}

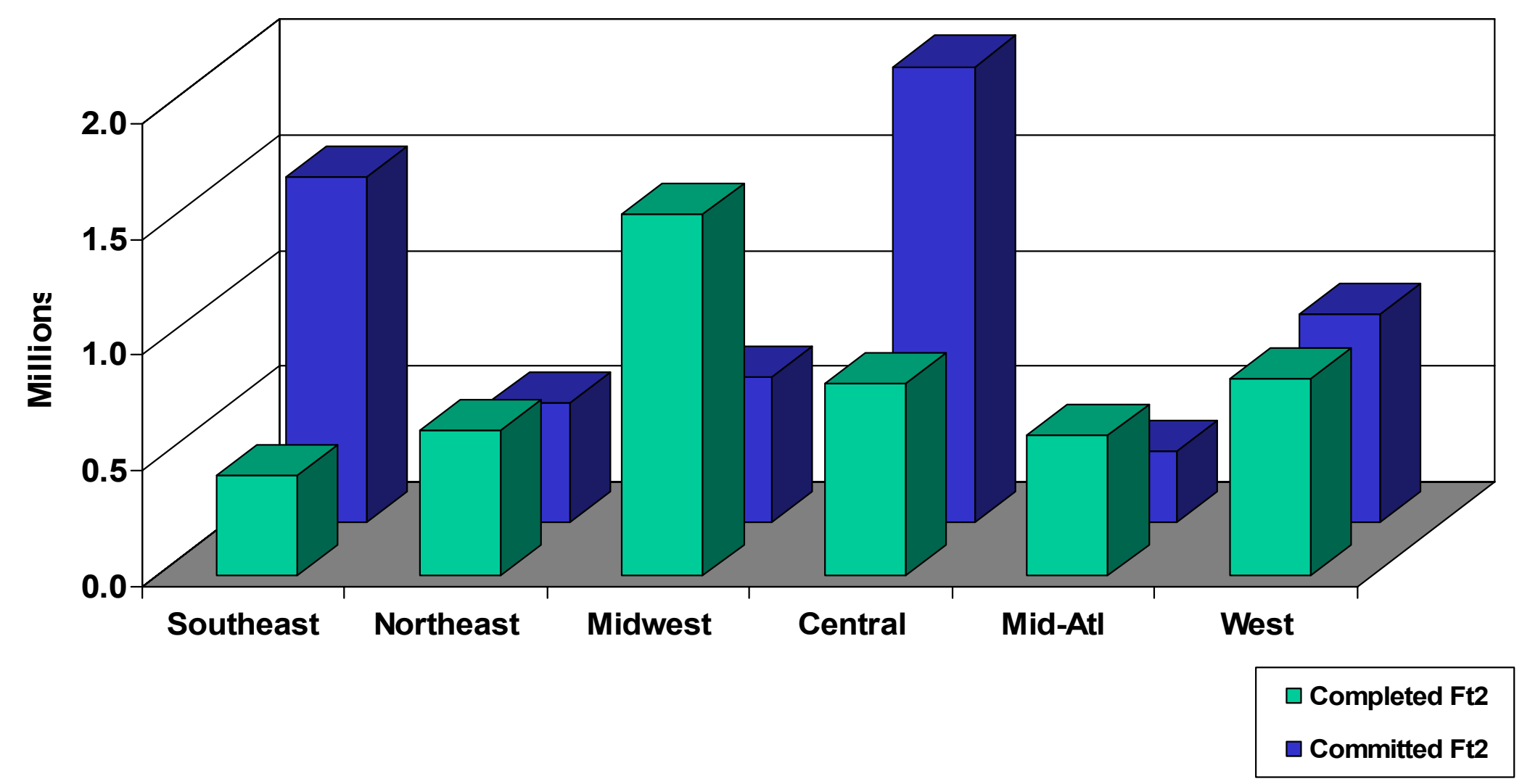




\section{Average Project Square Footage by Region: Excluding Highest and Lowest 5\%}

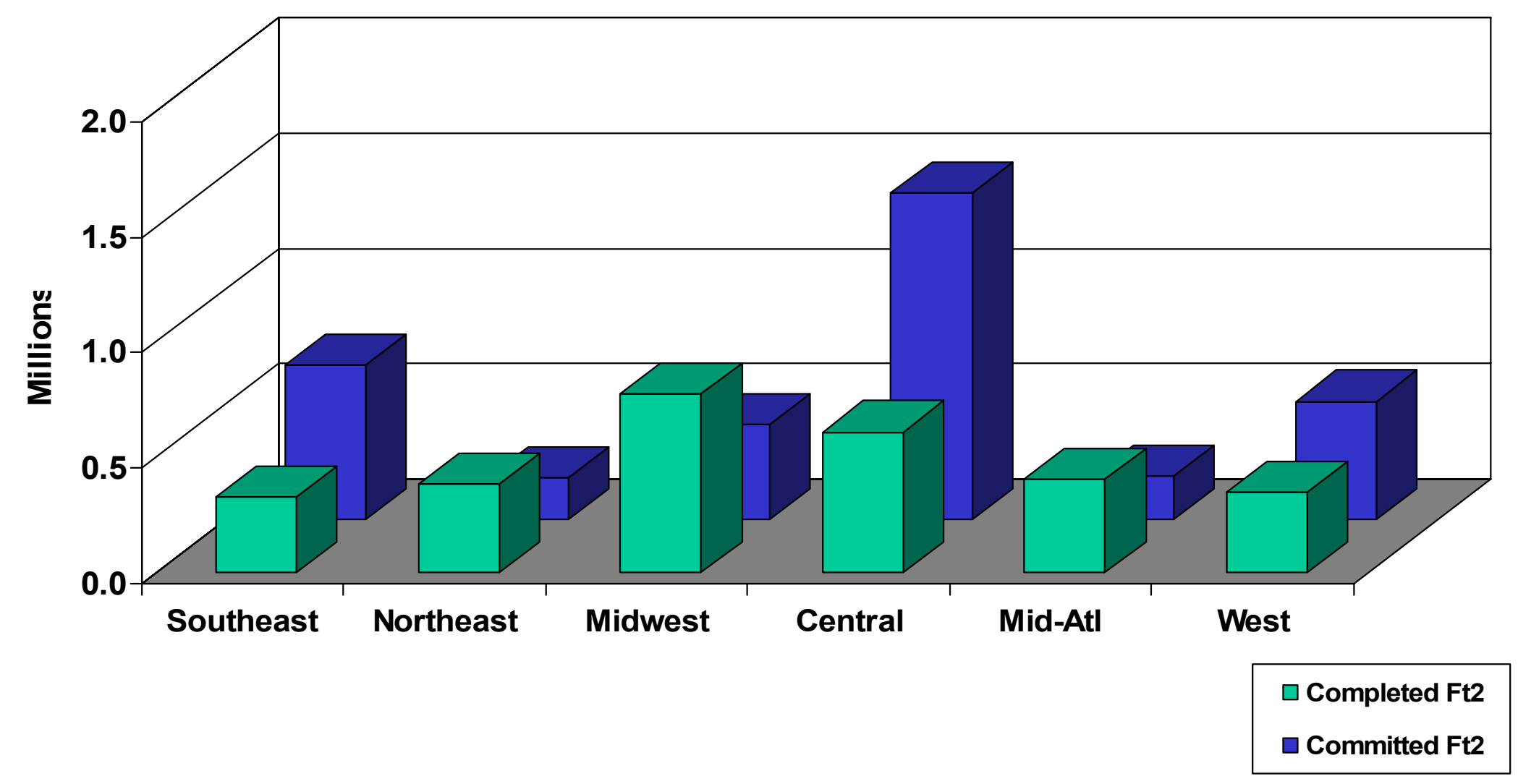




\section{Average Project Square Footage by Region: All Projects}

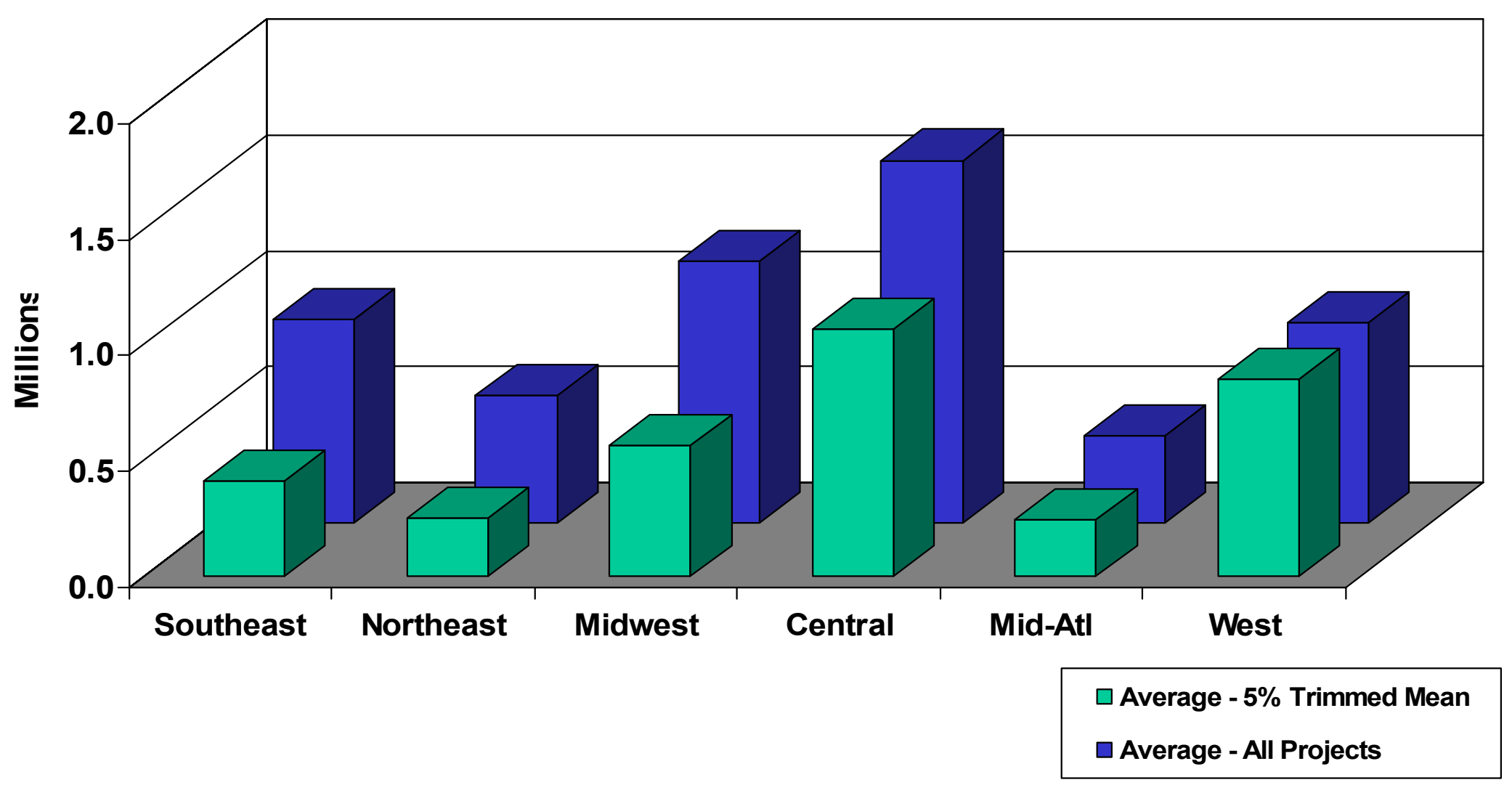




\section{Projects by Sector: Committed or Completed}

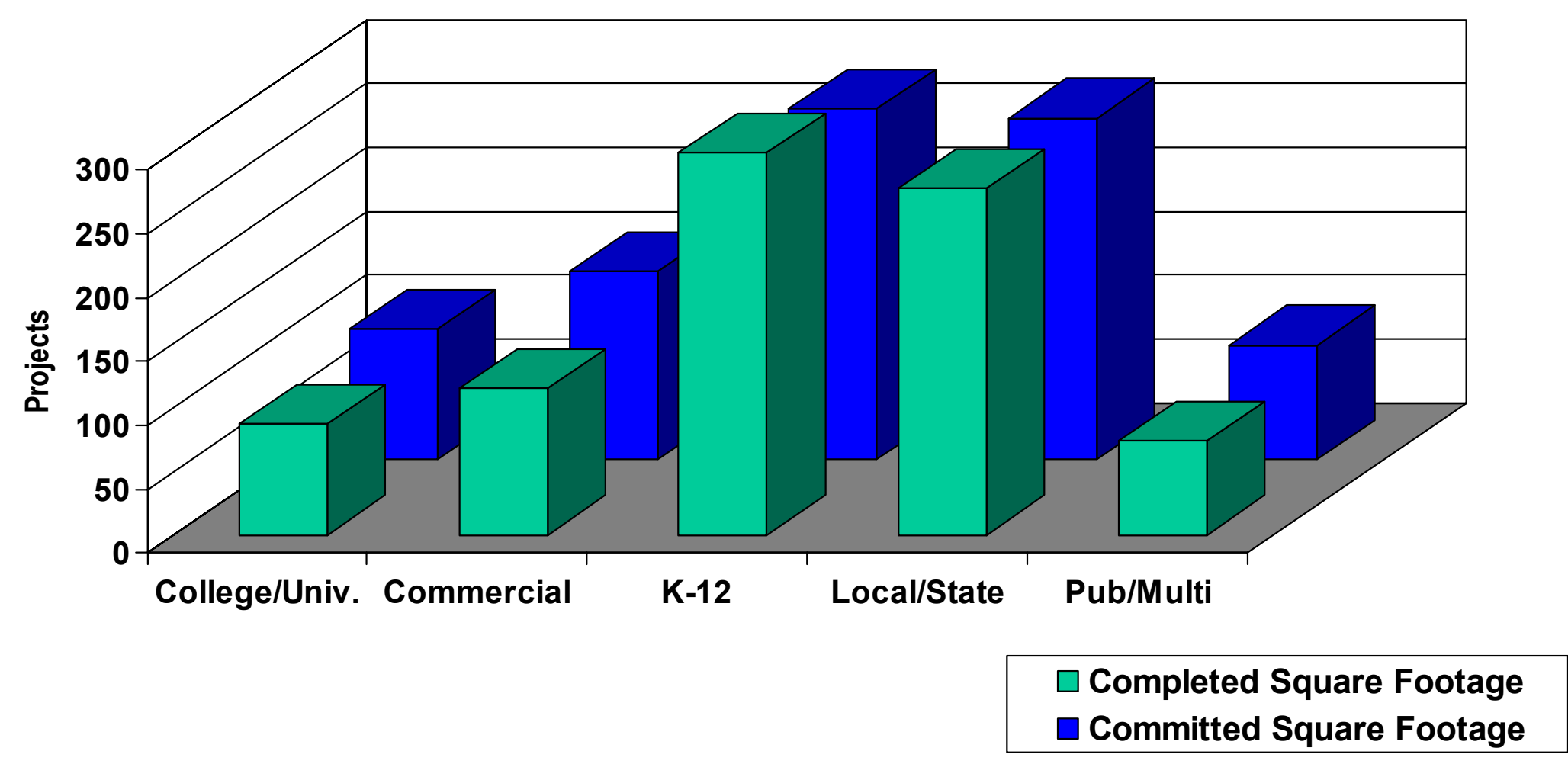




\section{Average Project Square Footage by Sector}

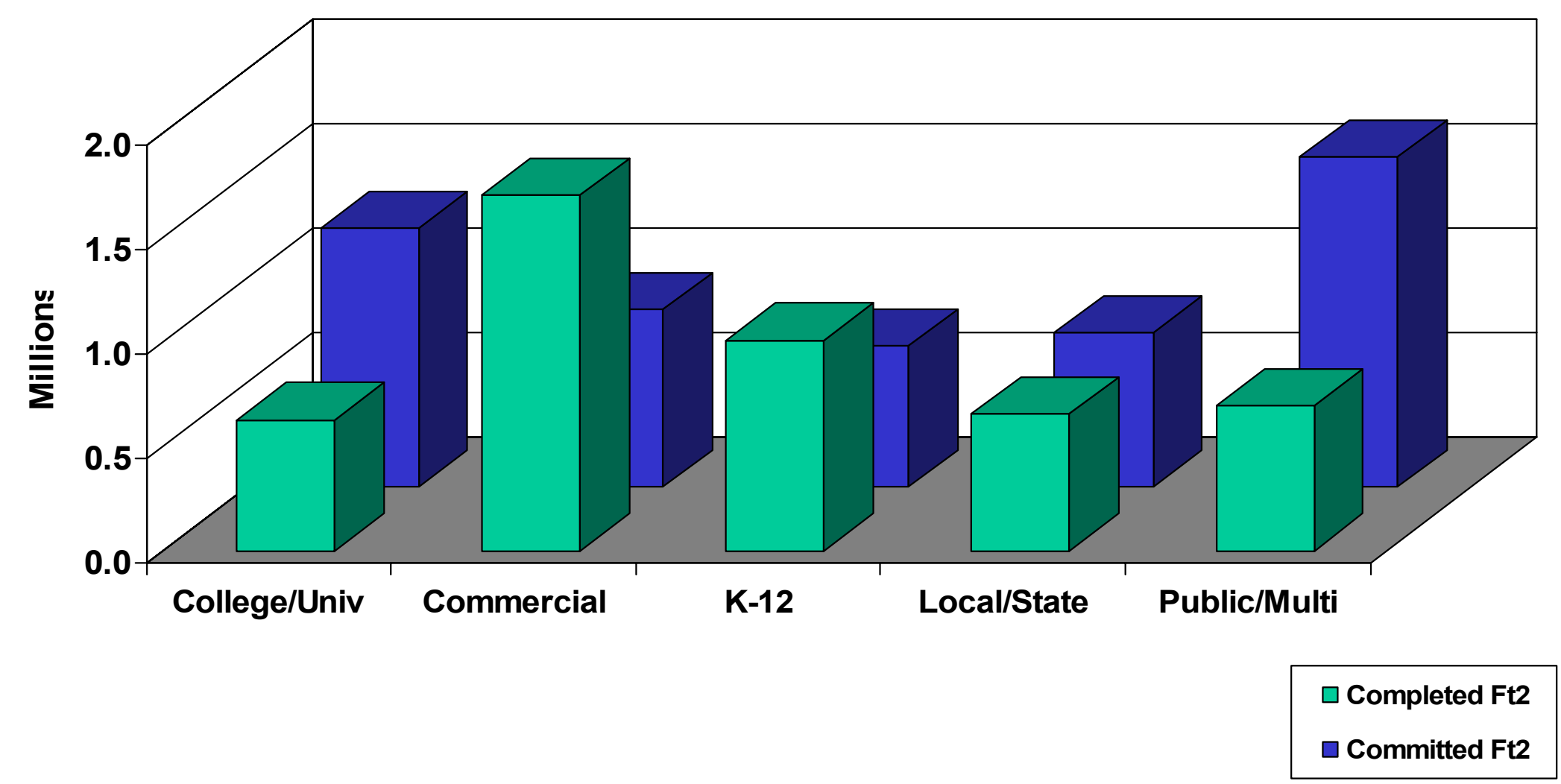




\section{Average Project Square Footage by Sector: Excluding Highest and Lowest 5\%}

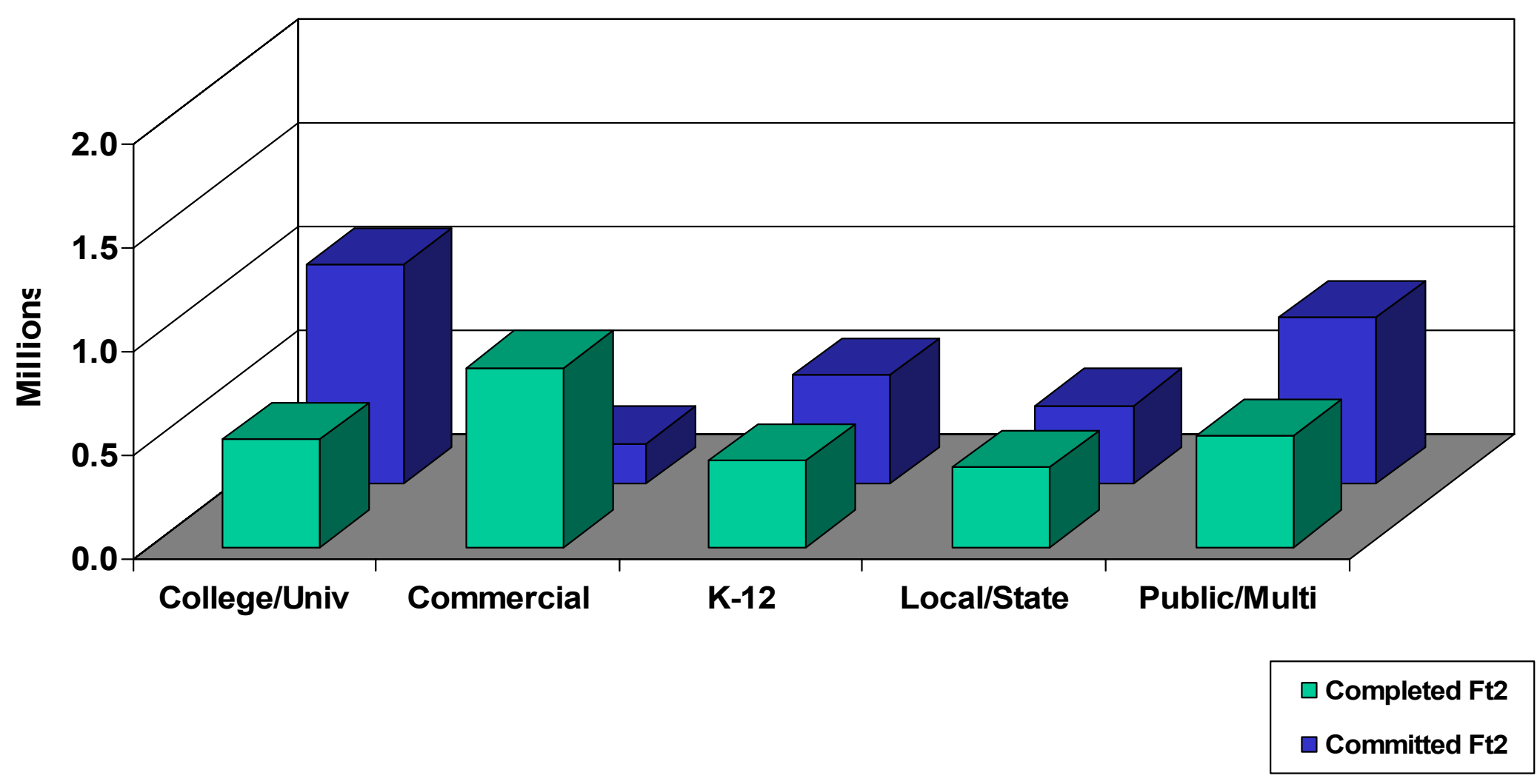




\section{Average Project Square Footage by Sector: All Projects}

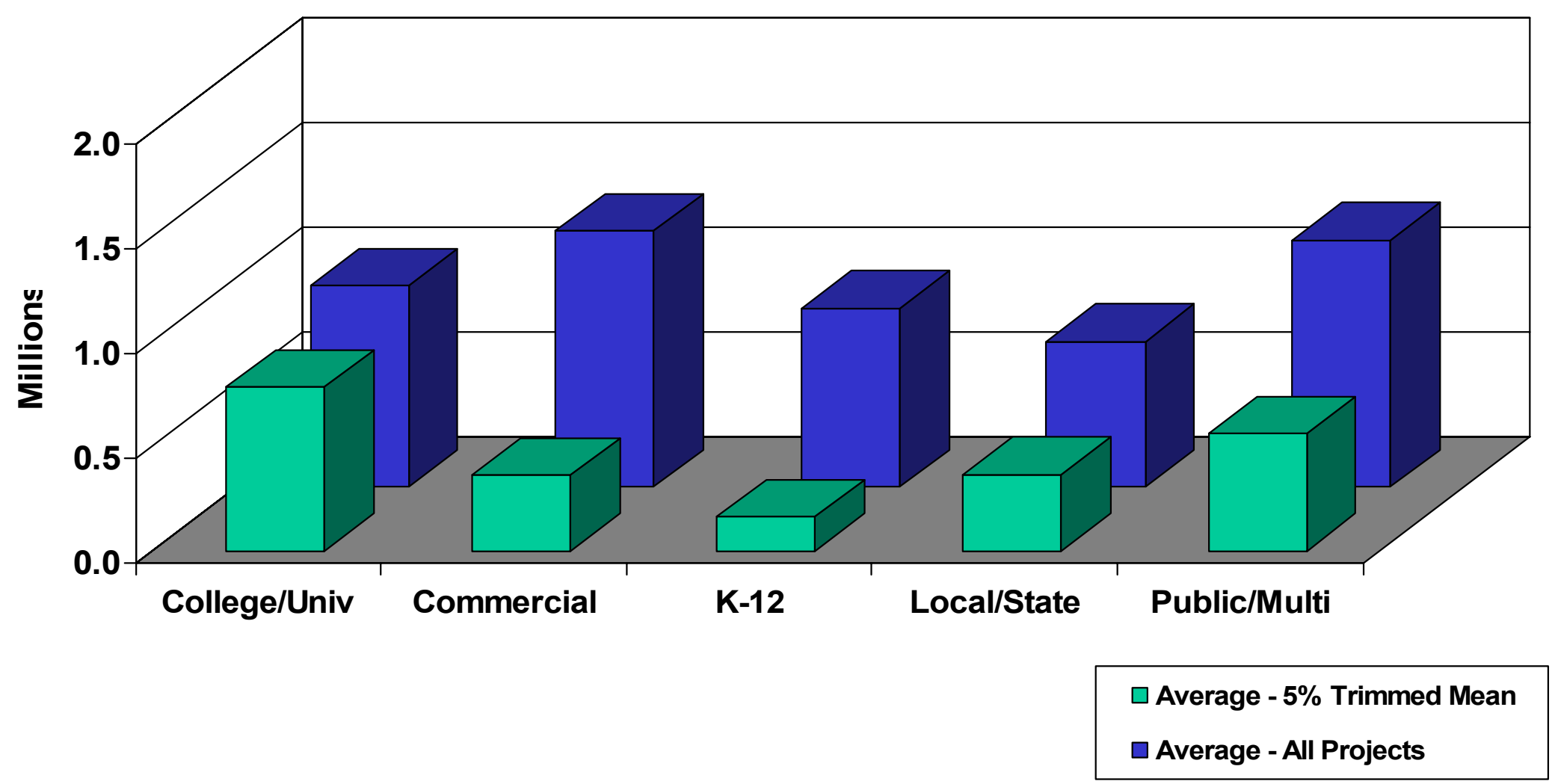




\section{Square Footage by Market Sector - 2003}

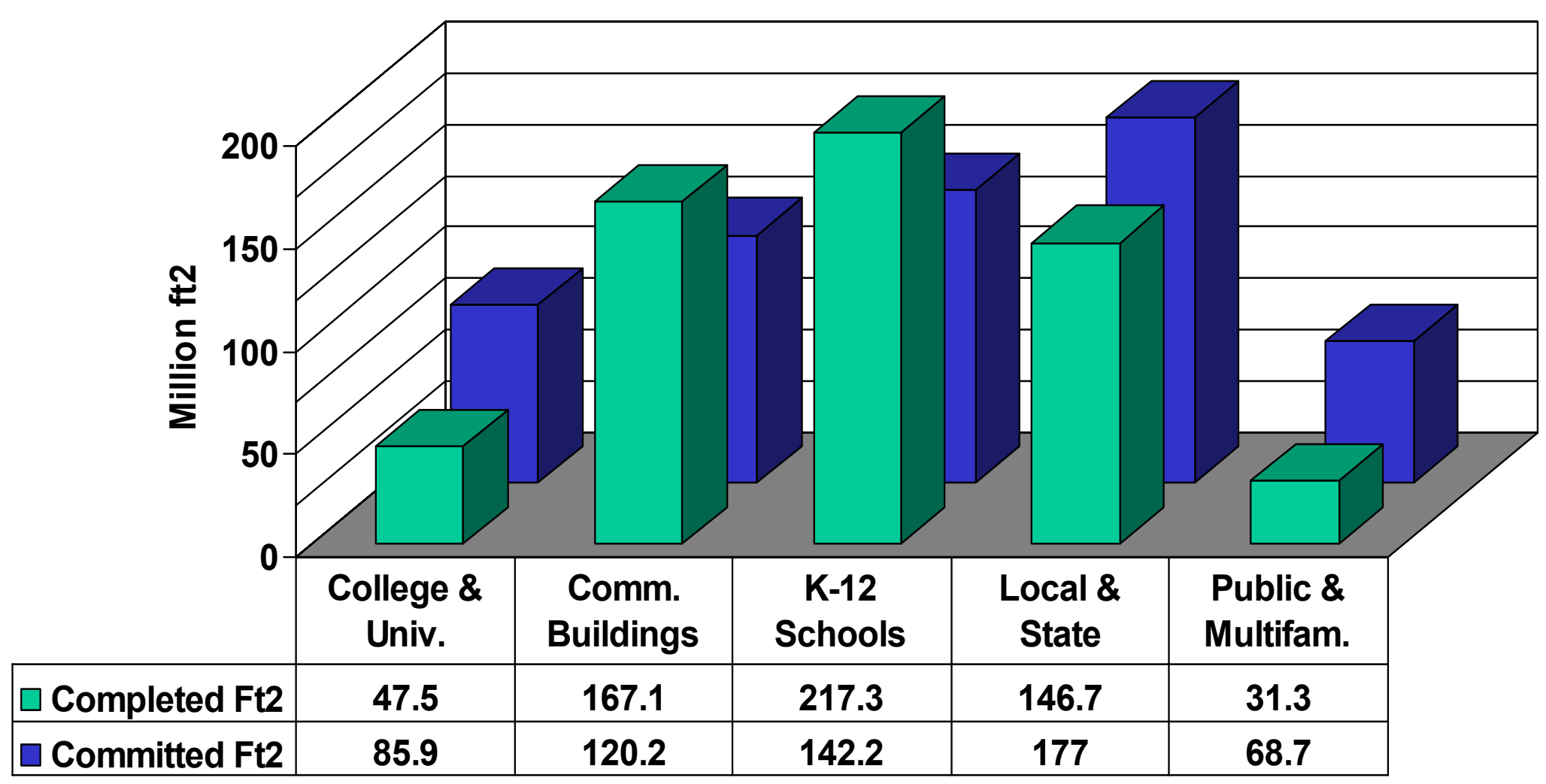




\section{Square Footage by Market Sector - 2004}

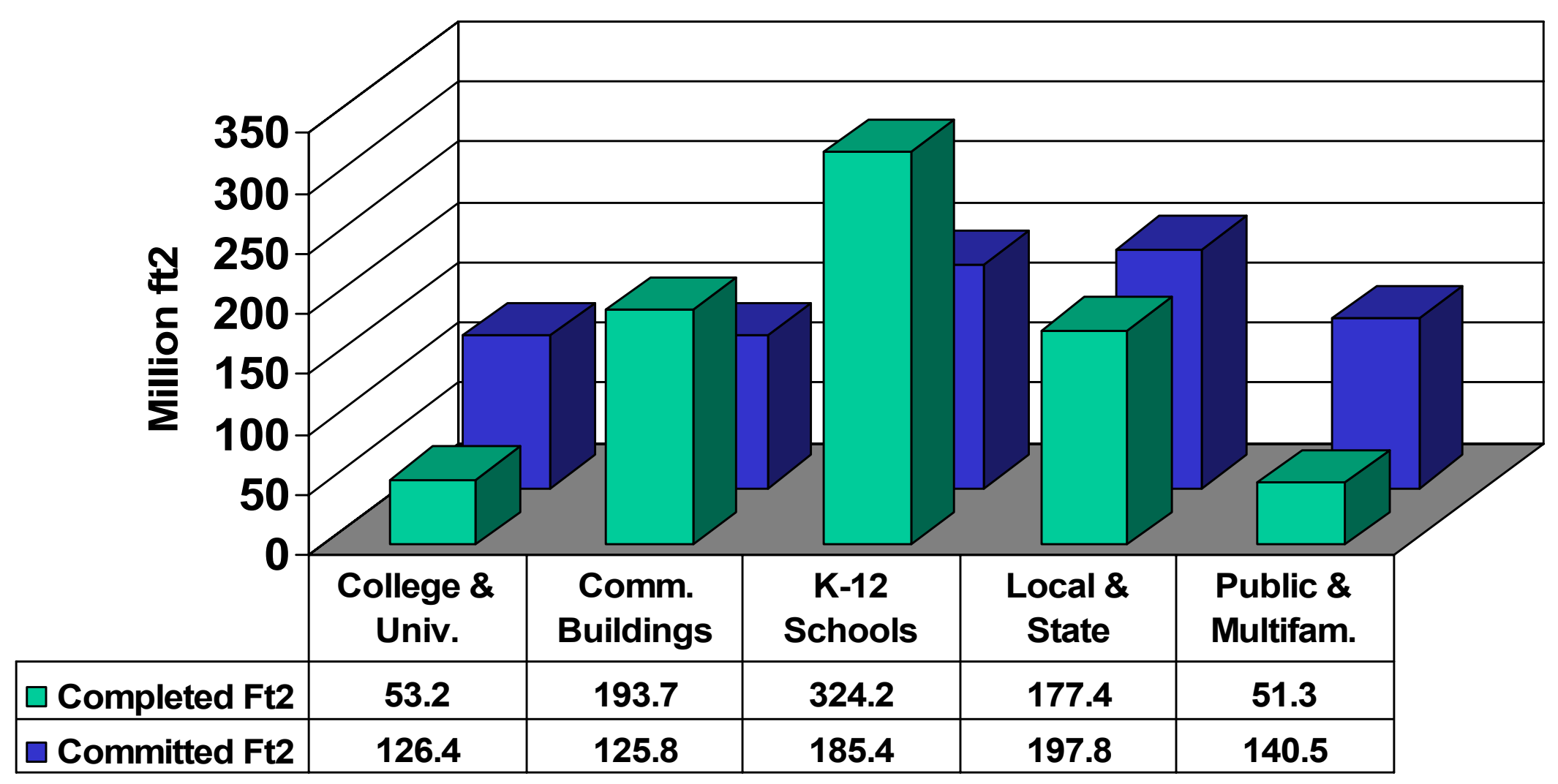




\section{Square Footage by Market Sector - 2003-2004 Change}

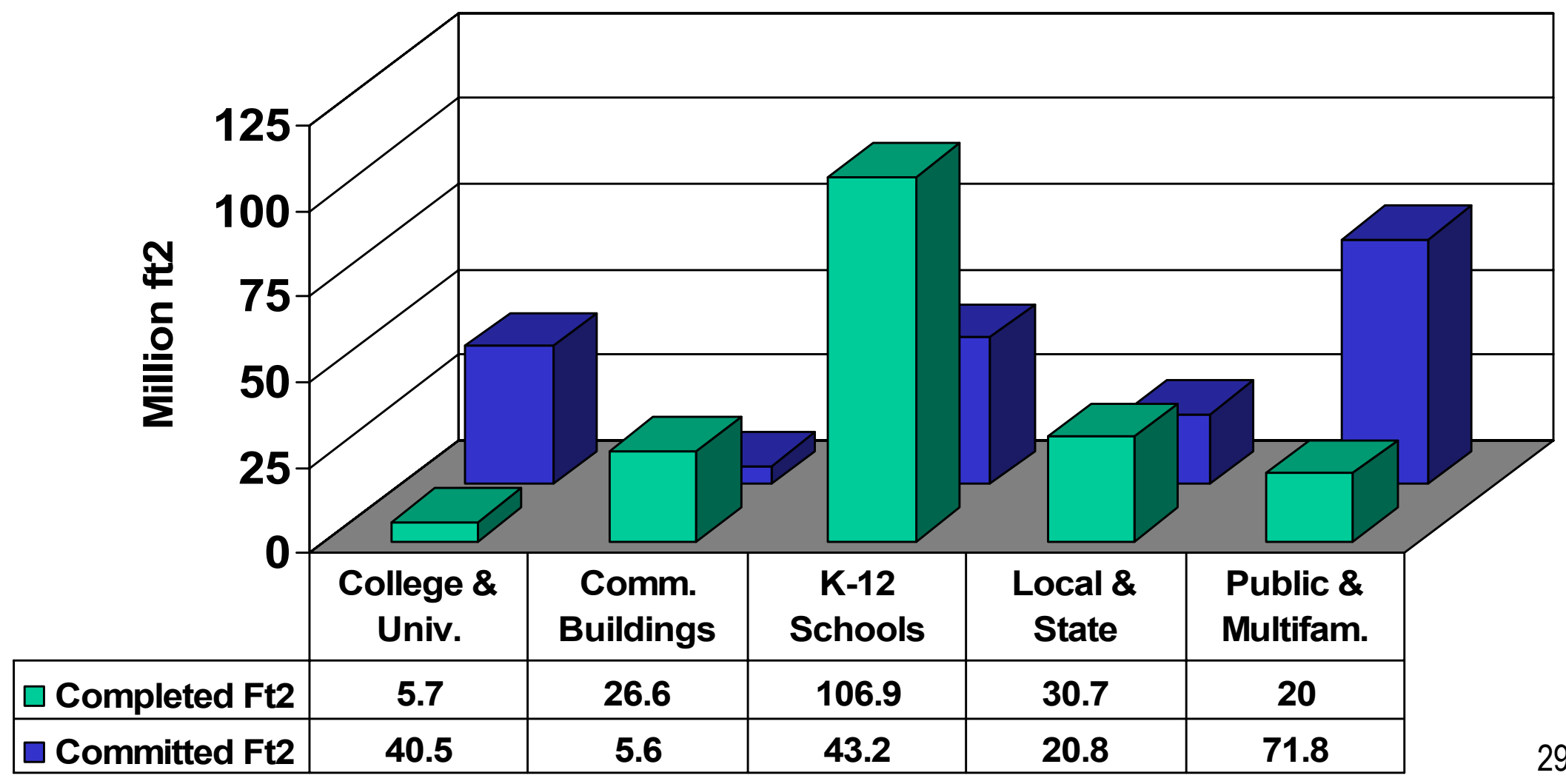




\section{Completed Square Footage by Market Sector}

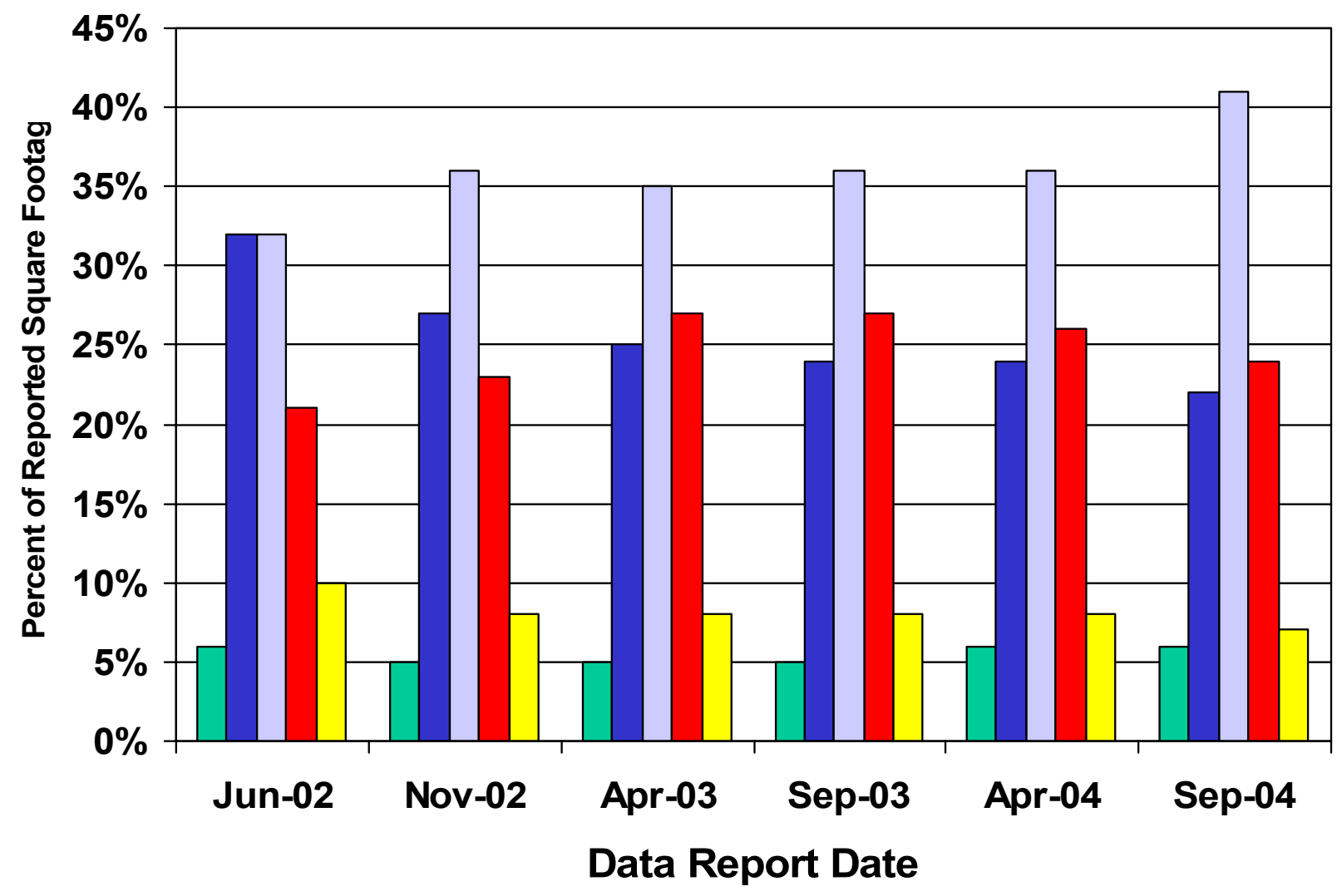

$\square$ Public \& Multifam. $\square$ Local \& State $\square$ K-12 Schools $\square$ Commercial Buildings $\square$ Colleges \& Univ. 


\section{Committed Square Footage by Market Sector}

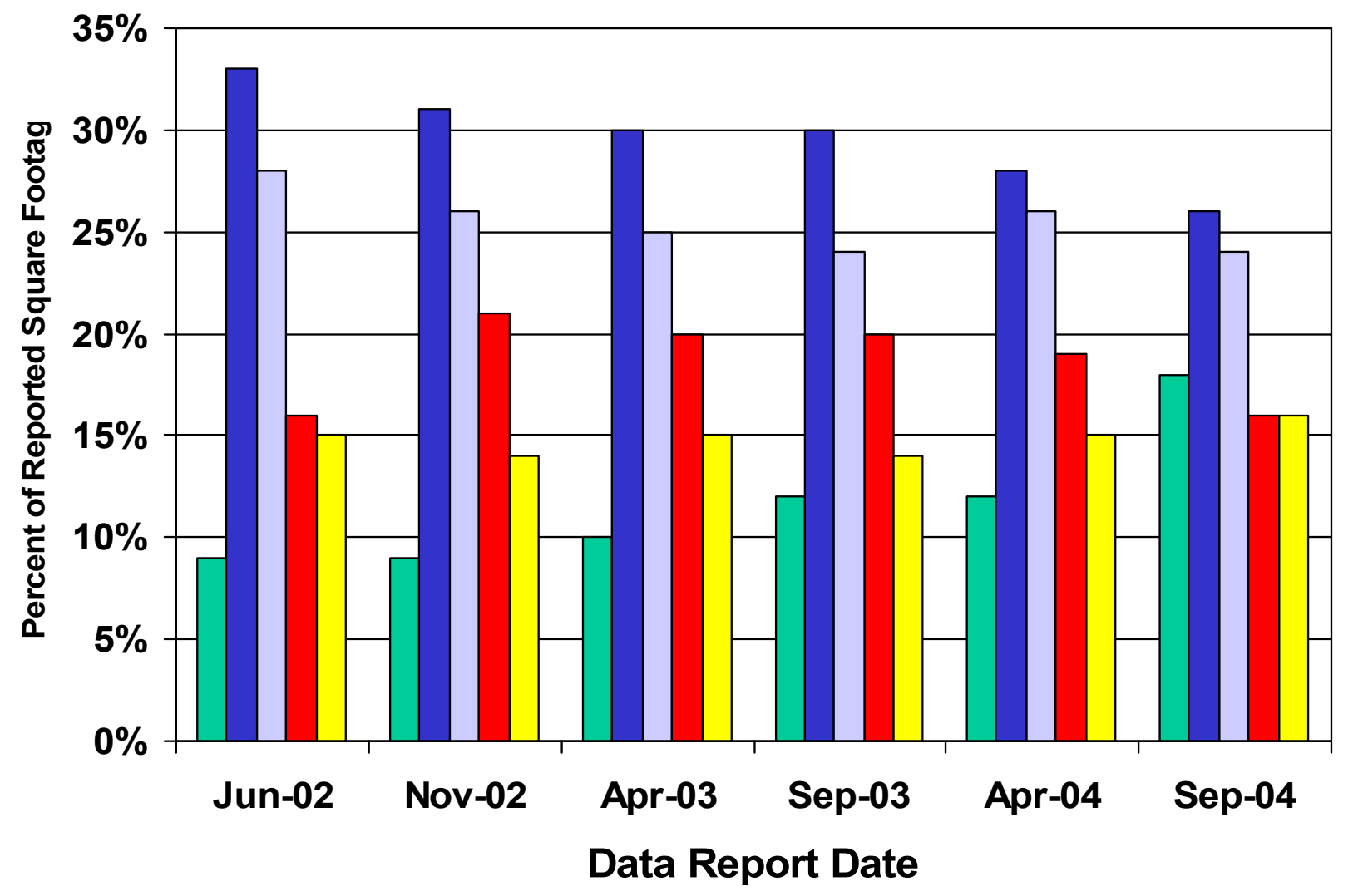

$\square$ Public \& Multifam. $\square$ Local \& State $\square$ K-12 Schools $\square$ Commercial Buildings $\square$ Colleges \& Univ. 


\section{Period-to-Period Growth by Market Sector - Committed Square Footage}

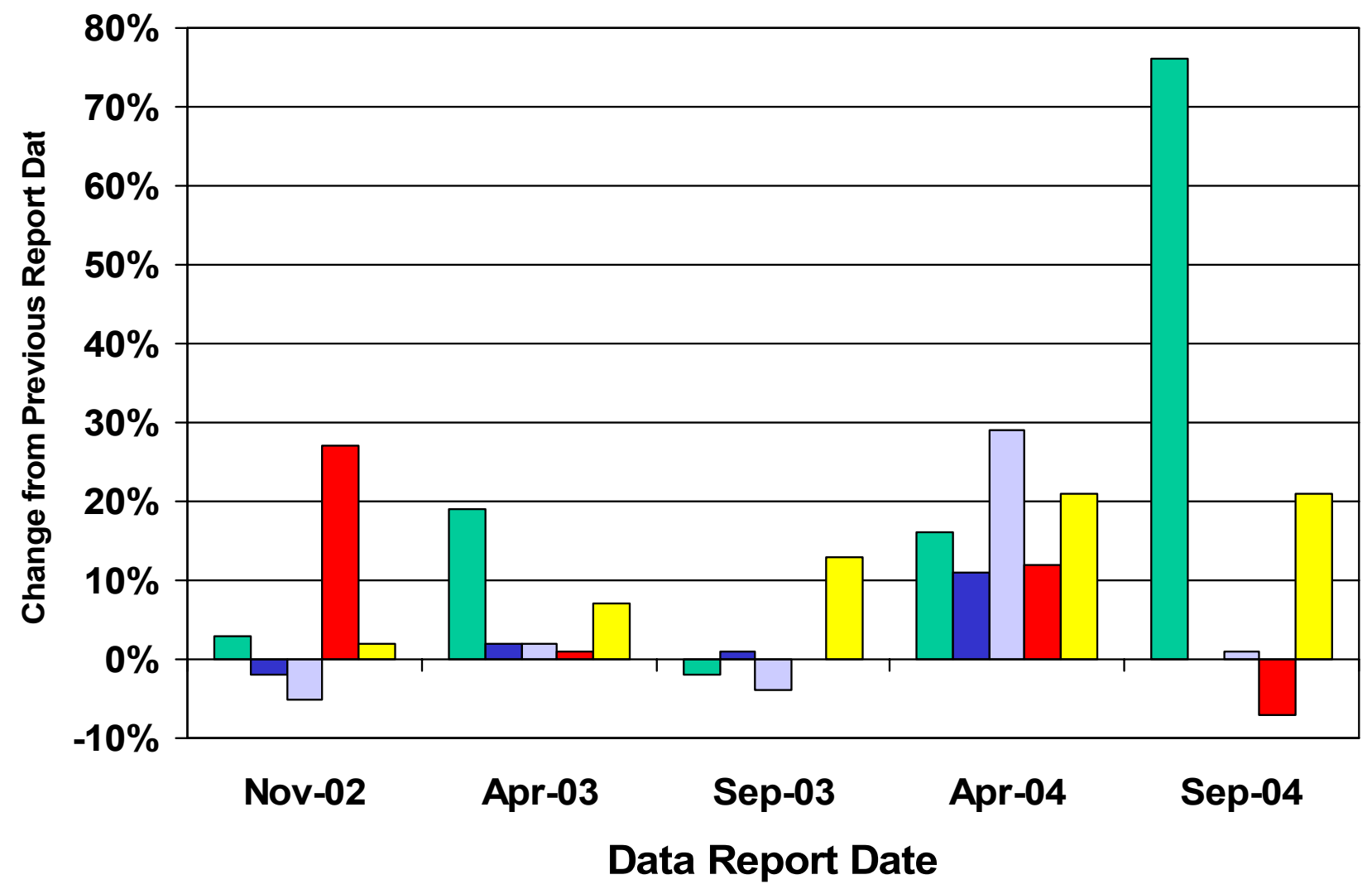

$\square$ Public \& Multifam.

$\square$ Local \& State

$\square$ K-12 Schools

$\square$ Commercial Buildings

$\square$ Colleges \& Univ. 


\section{Period-to-Period Growth by Market Sector - Completed Square Footage}

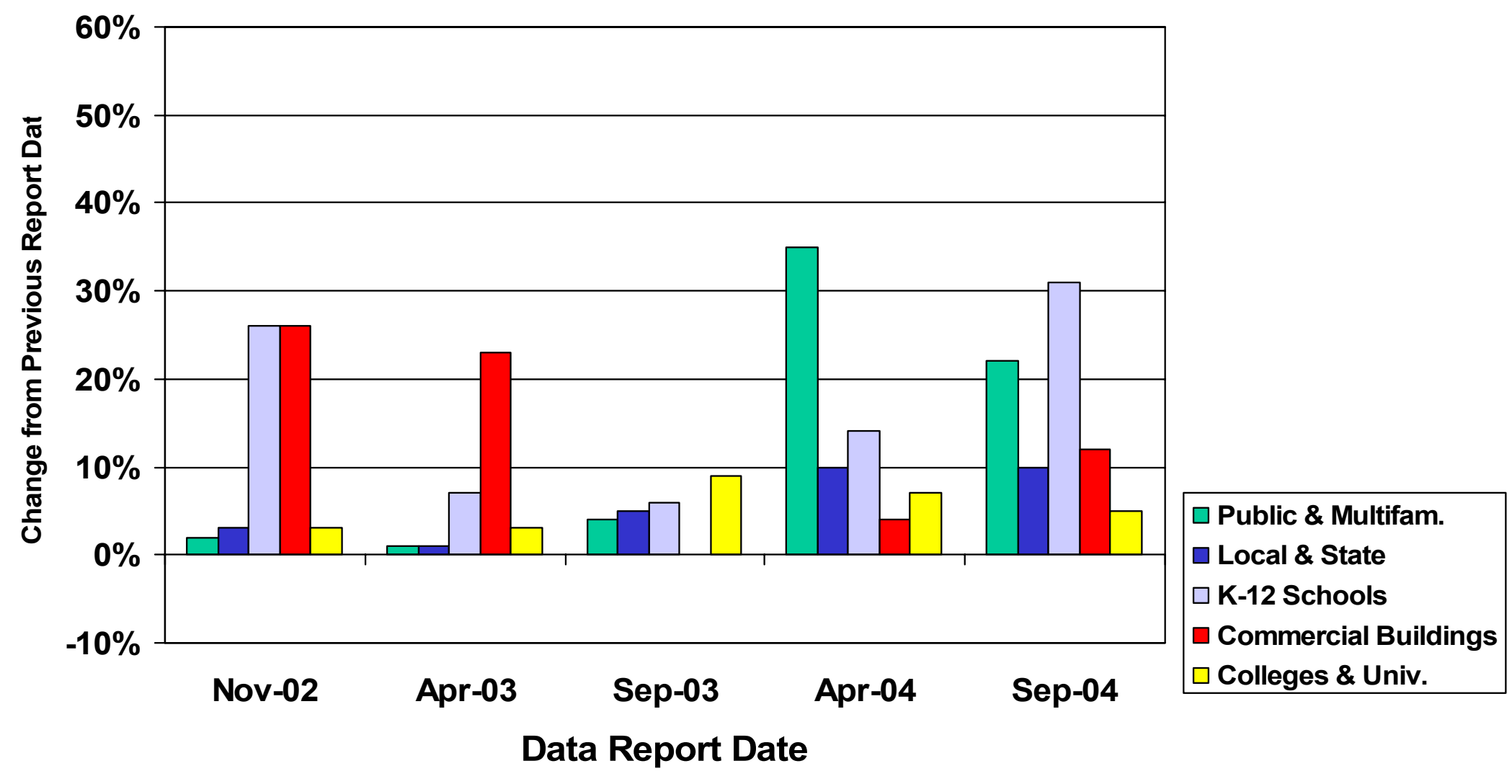




\section{Percent Square Footage Growth by Market Sector: May 2001 - Sept 2004}

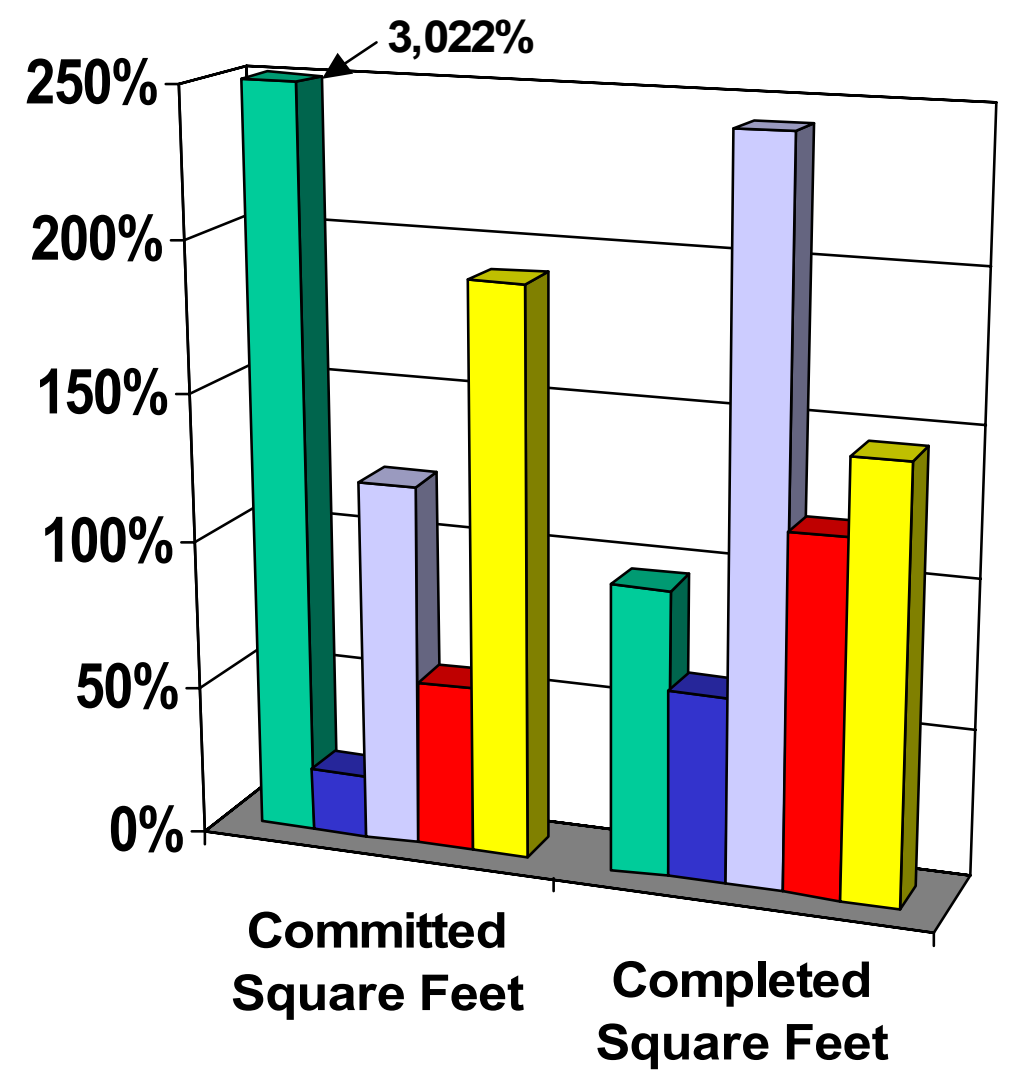

$\square$ Public \& Multifam.

$\square$ Local \& State

$\square$ K-12 Schools

$\square$ Commercial Buildings

$\square$ Colleges \& Univ. 


\section{Regional Potential and Current Committed/ Completed Square Footage}

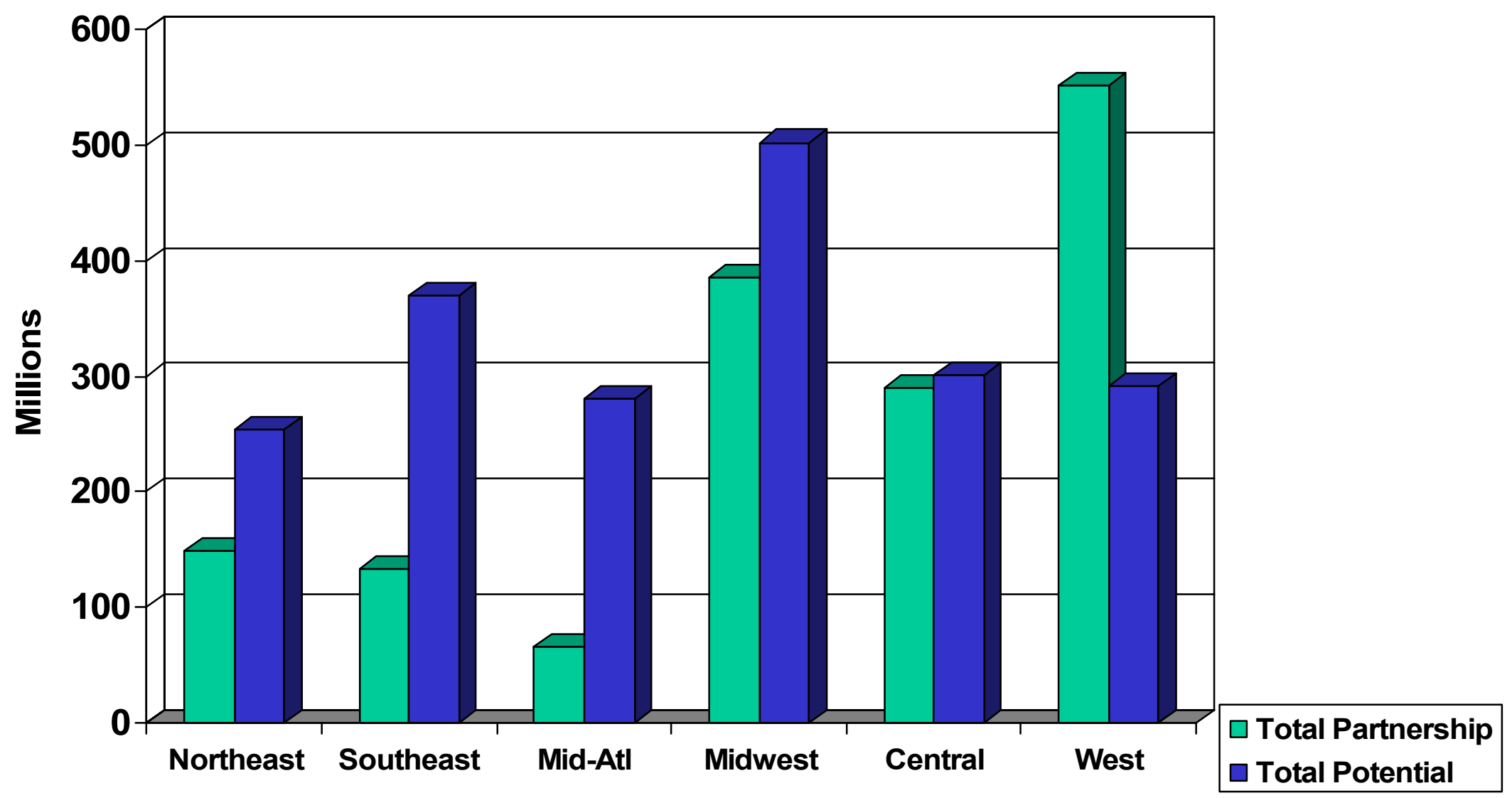




\section{Technical Assistance Services} Analysis 


\section{Assistance Requests by Month}

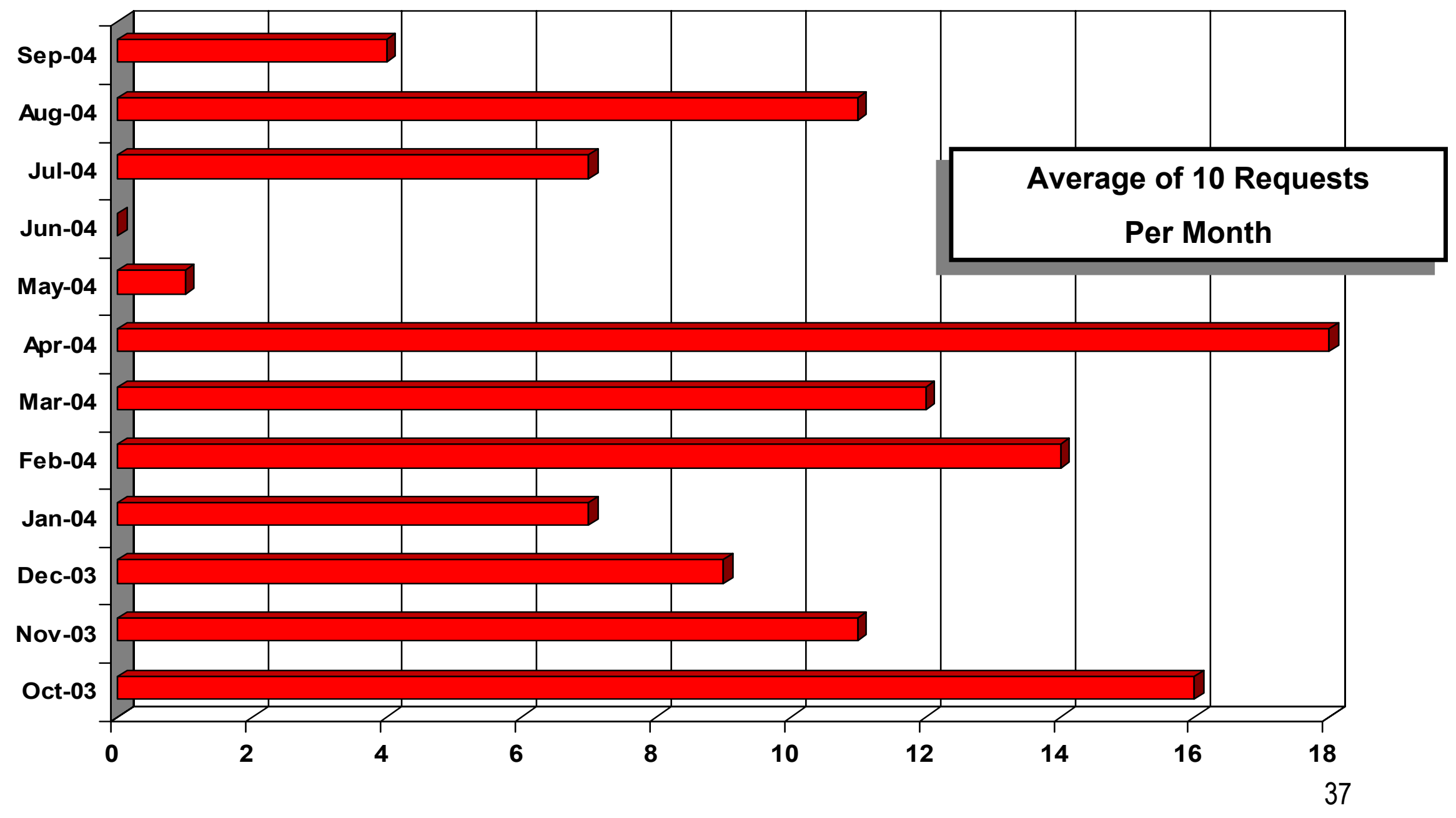




\section{Assistance Requests by Month - 2003 - 2004}

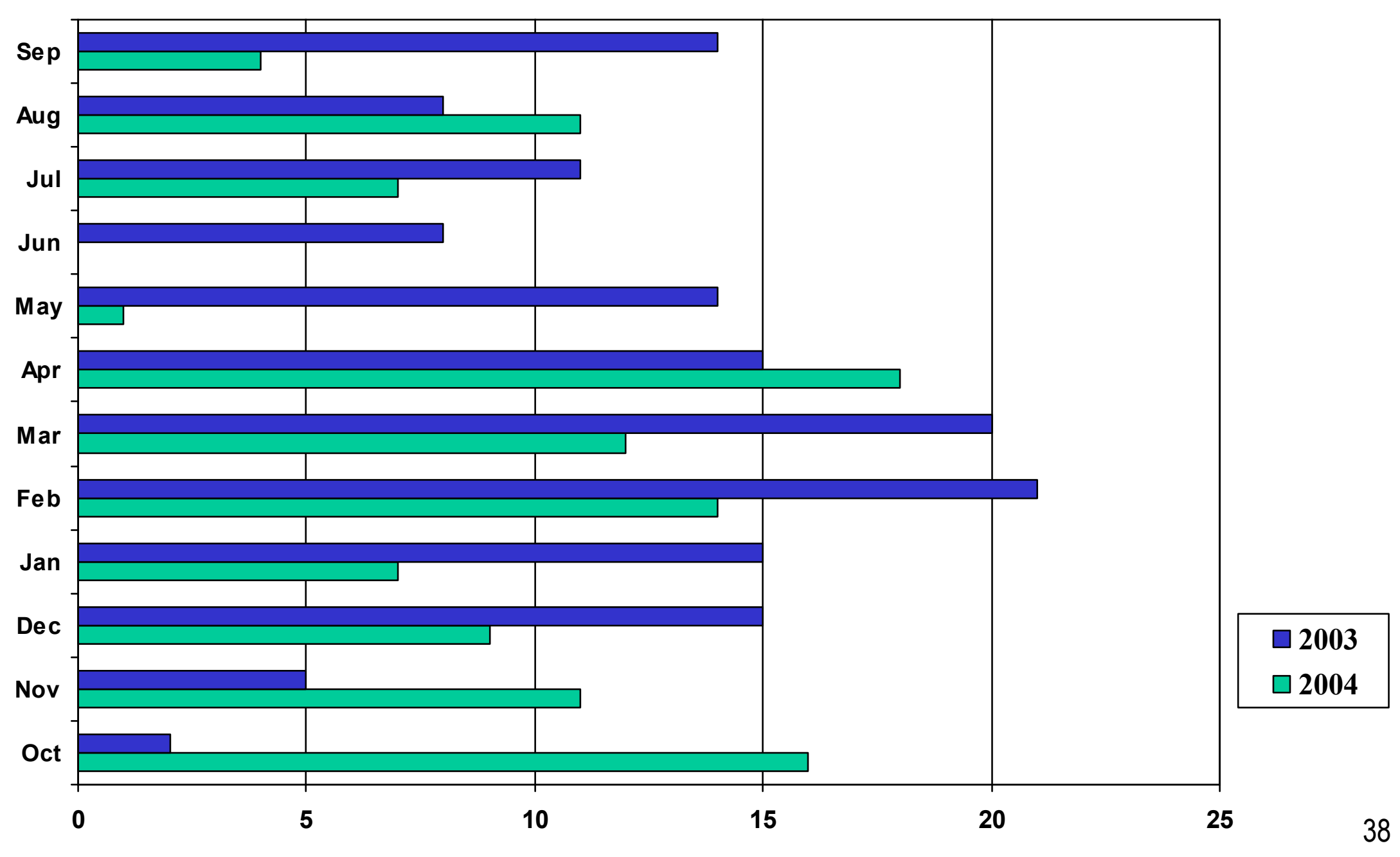




\section{Assistance Requests by Region}

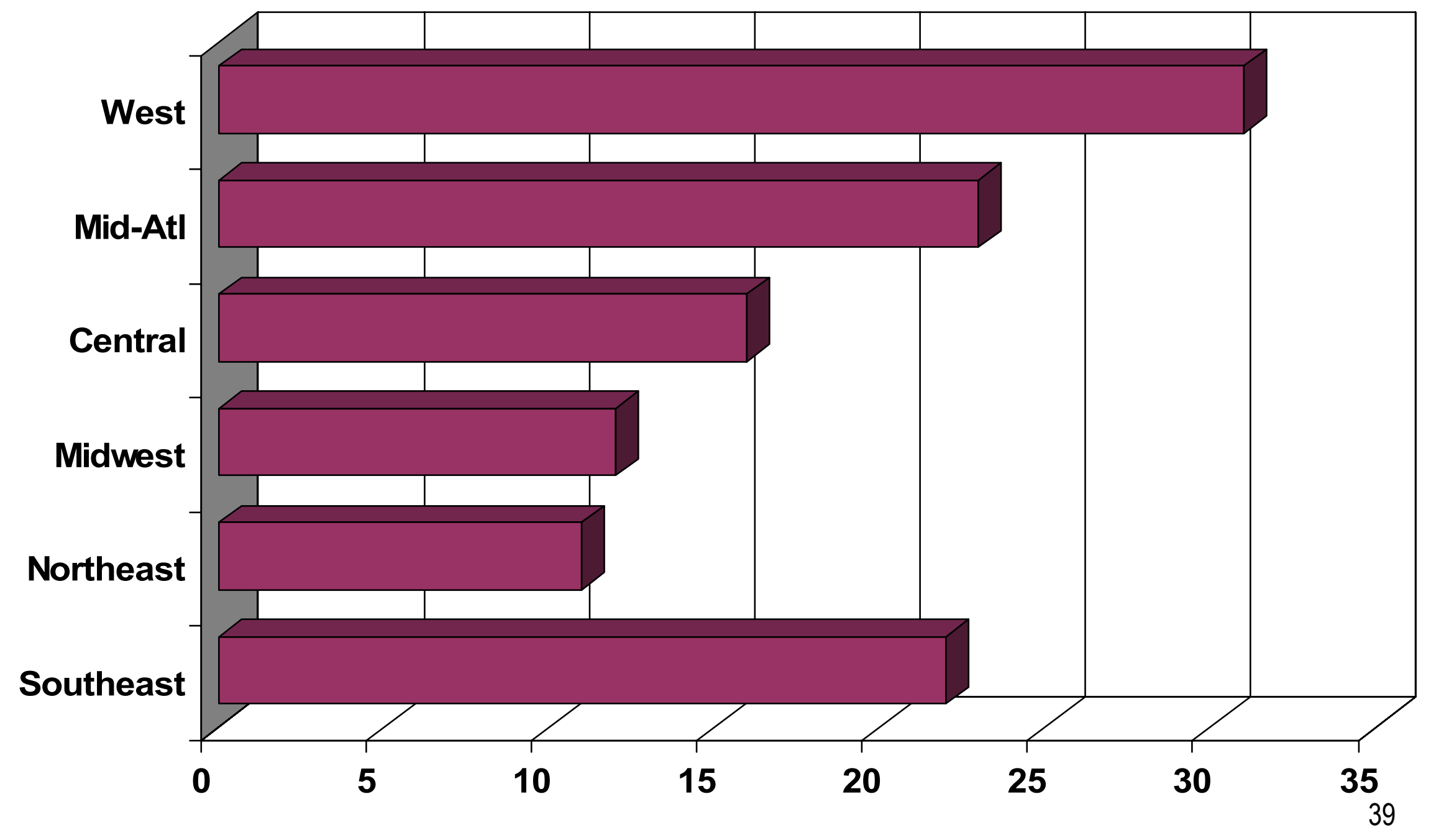




\section{Assistance Requests by Region - 2003-2004}

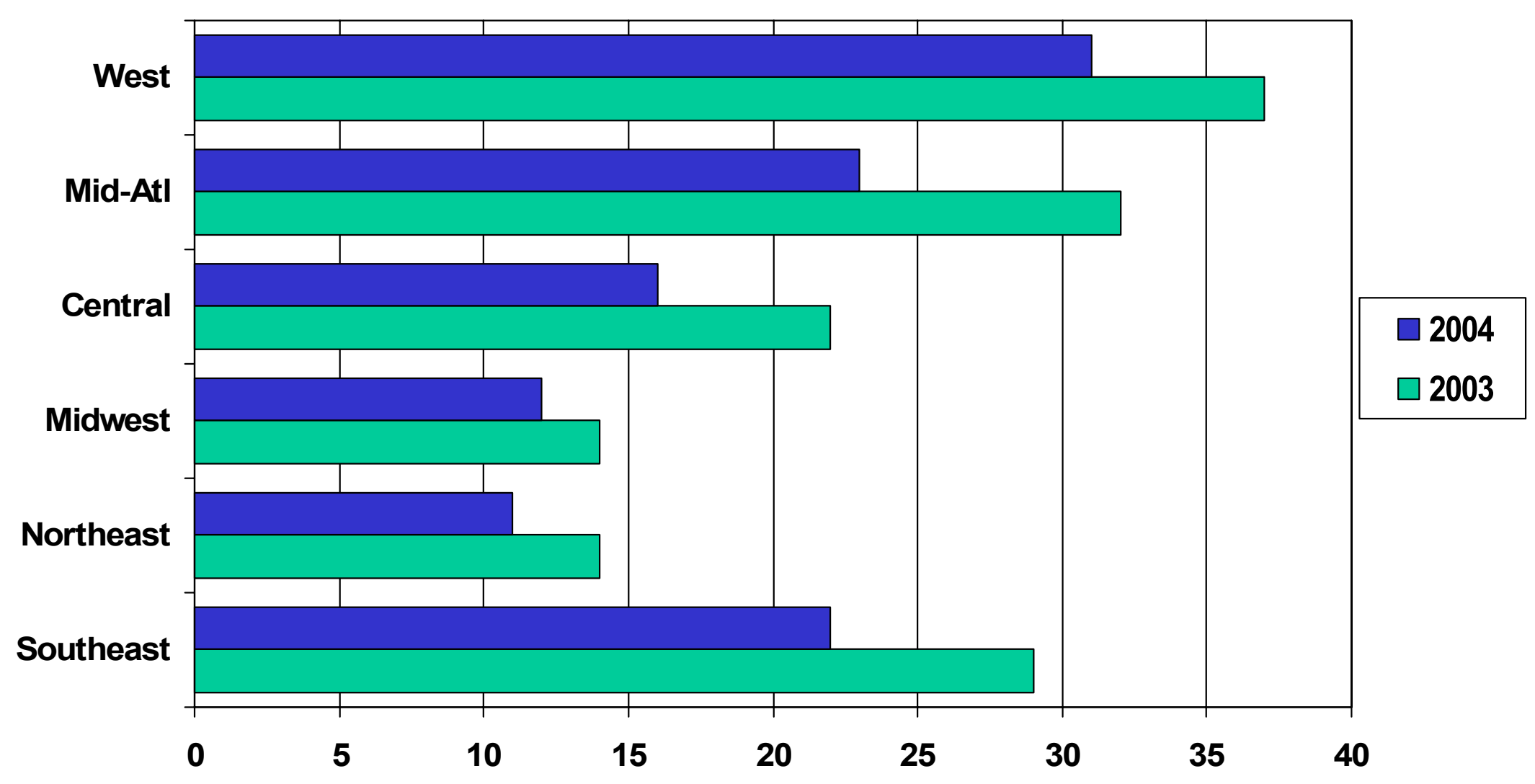




\section{Requests Breakdown by Region}

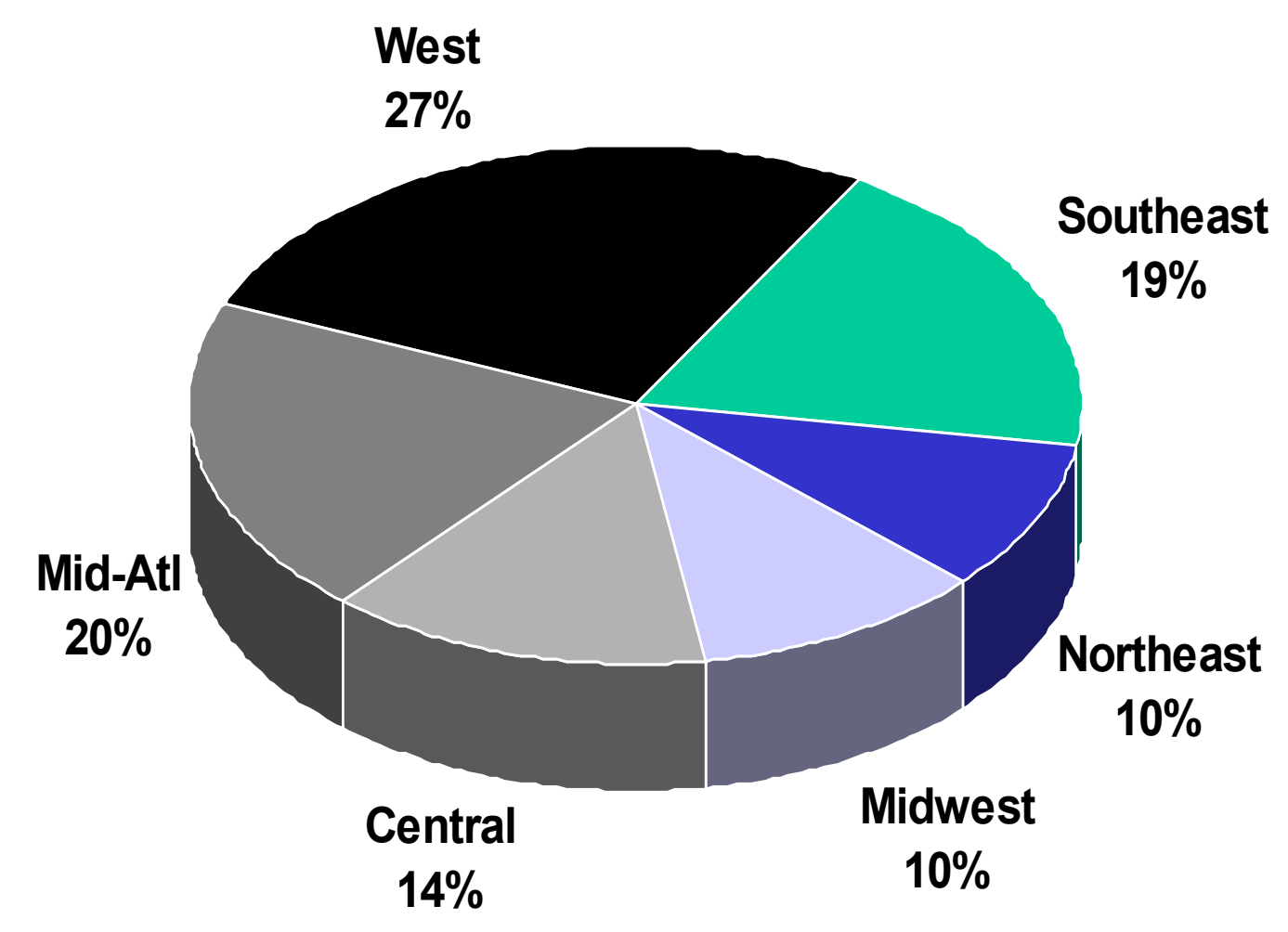




\section{Request Originators}

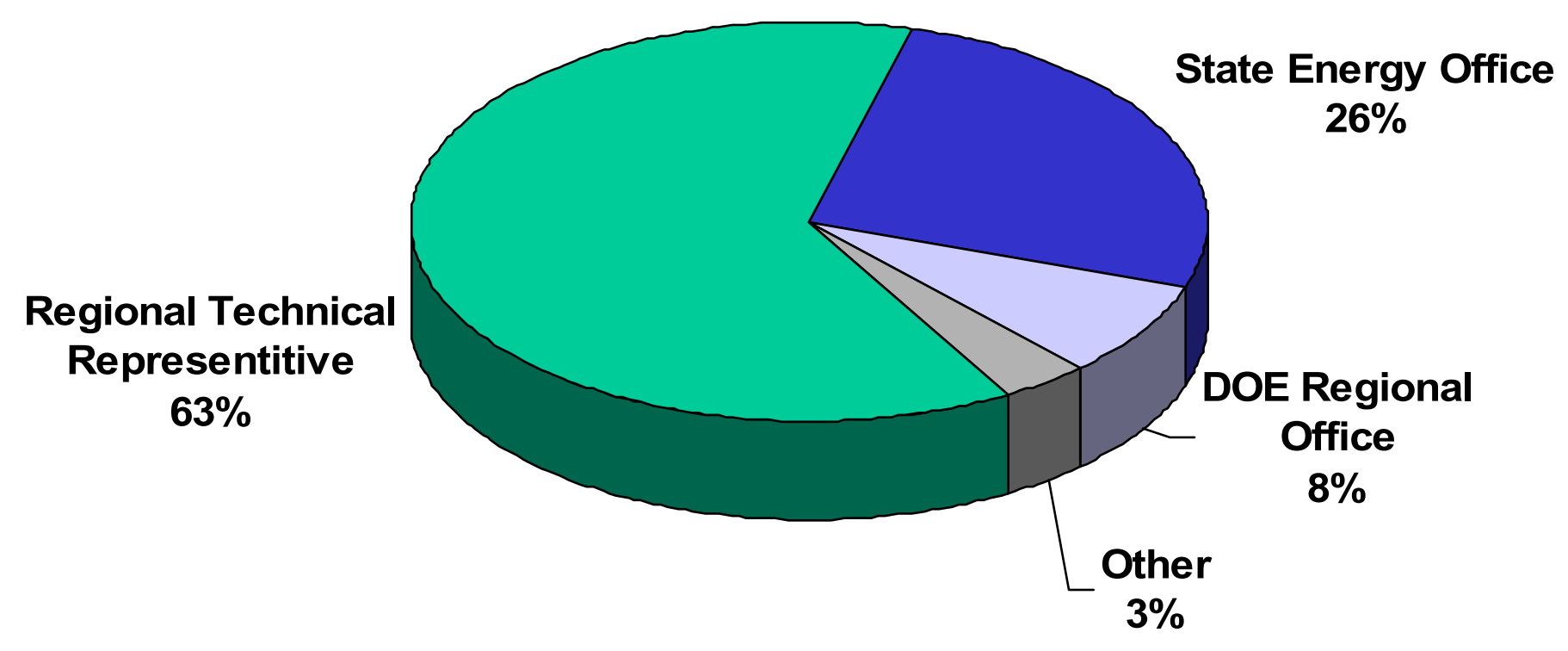




\section{Requests by Sector}

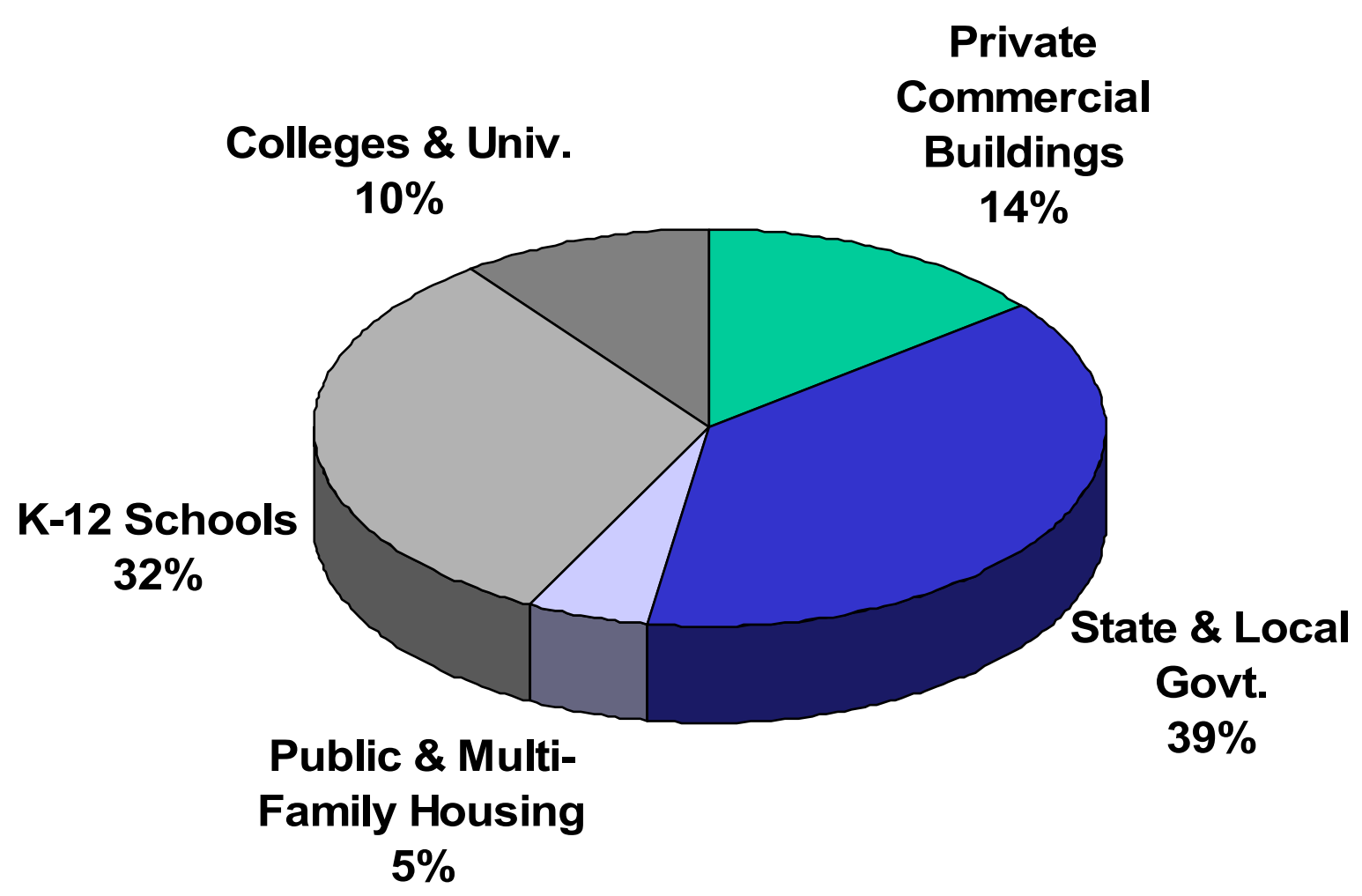




\section{Assistance Provider Grouped by Organization}

\section{3}

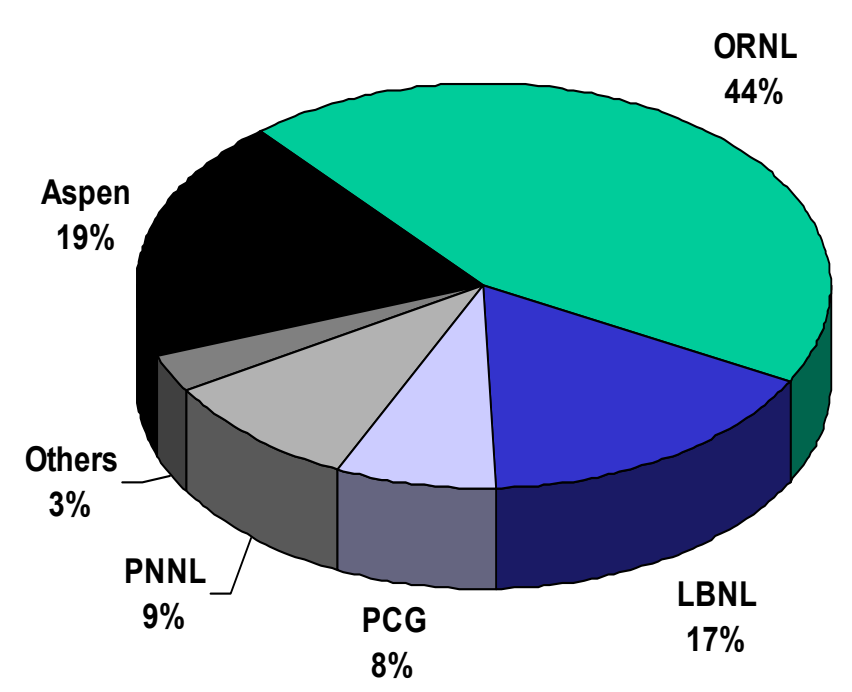

2004

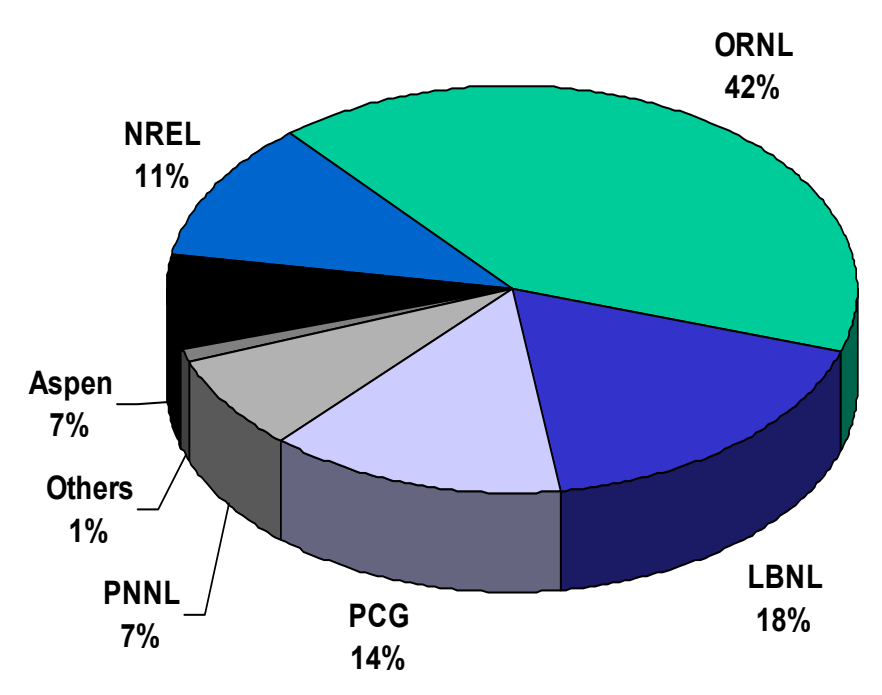




\section{FY 2003 Technical Assistance Type Breakdown}

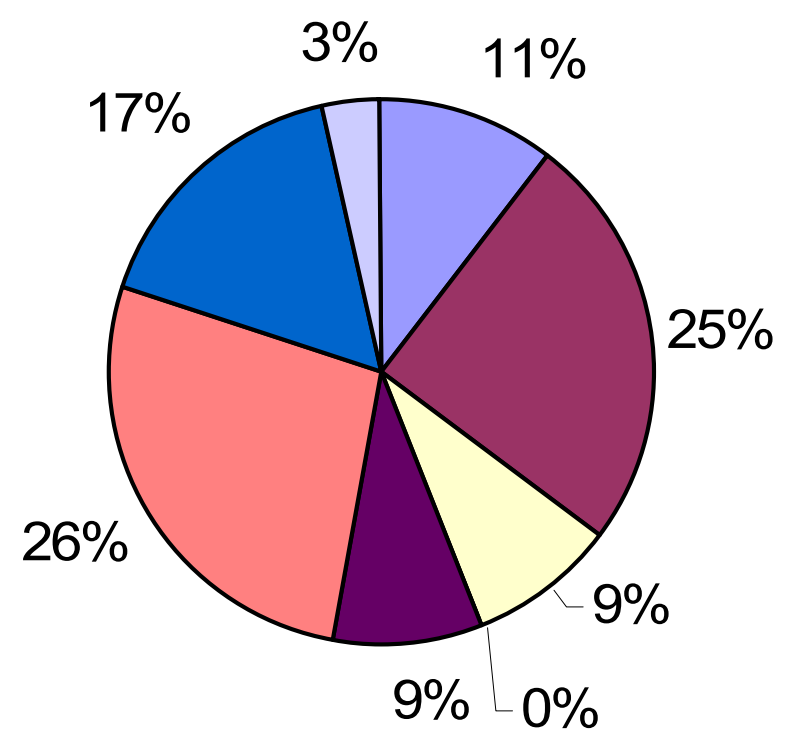

$\square$ Analysis
$\square$ Information
$\square$ Inspection
$\square$ Model
$\square$ Other (Marketing)
$\square$ Presentation
$\square$ Review
$\square$ Training




\section{FY 2004 Technical Assistance Type Breakdown}

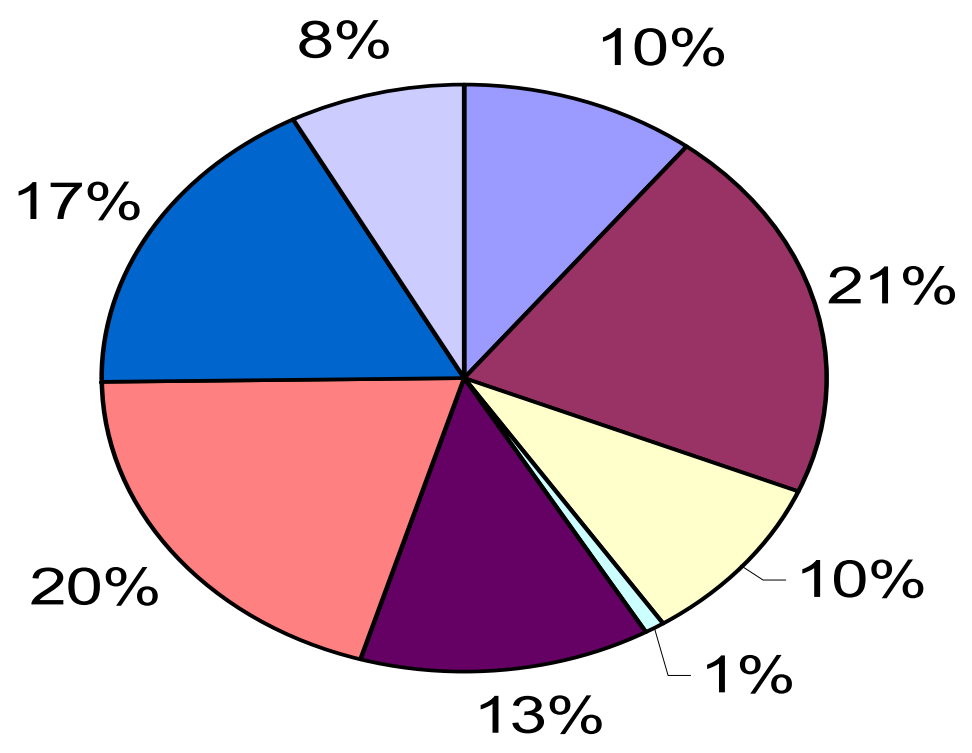

$\square$ Analysis
$\square$ Information
$\square$ Inspection
$\square$ Model
$\square$ Other (Marketing)
$\square$ Presentation
$\square$ Review
$\square$ Training




\section{TA Sector Analysis by Percentage}

\begin{tabular}{|l|r|r|r|r|r|r|}
\hline & \multicolumn{1}{|c|}{ C } & \multicolumn{1}{c|}{ H } & \multicolumn{1}{|c|}{ K-12 } & \multicolumn{1}{c|}{ L } & \multicolumn{1}{c|}{ U } \\
\hline
\end{tabular}




\section{Product Distribution}

- Fiscal Year of 2004

- 1080 total requests

- 179 via Online Store vs. 901 phone/e-mail

- 86,973 items shipped

- includes 37,403 Partner Updates 


\section{Distribution Center Delivery Time}

\section{3}

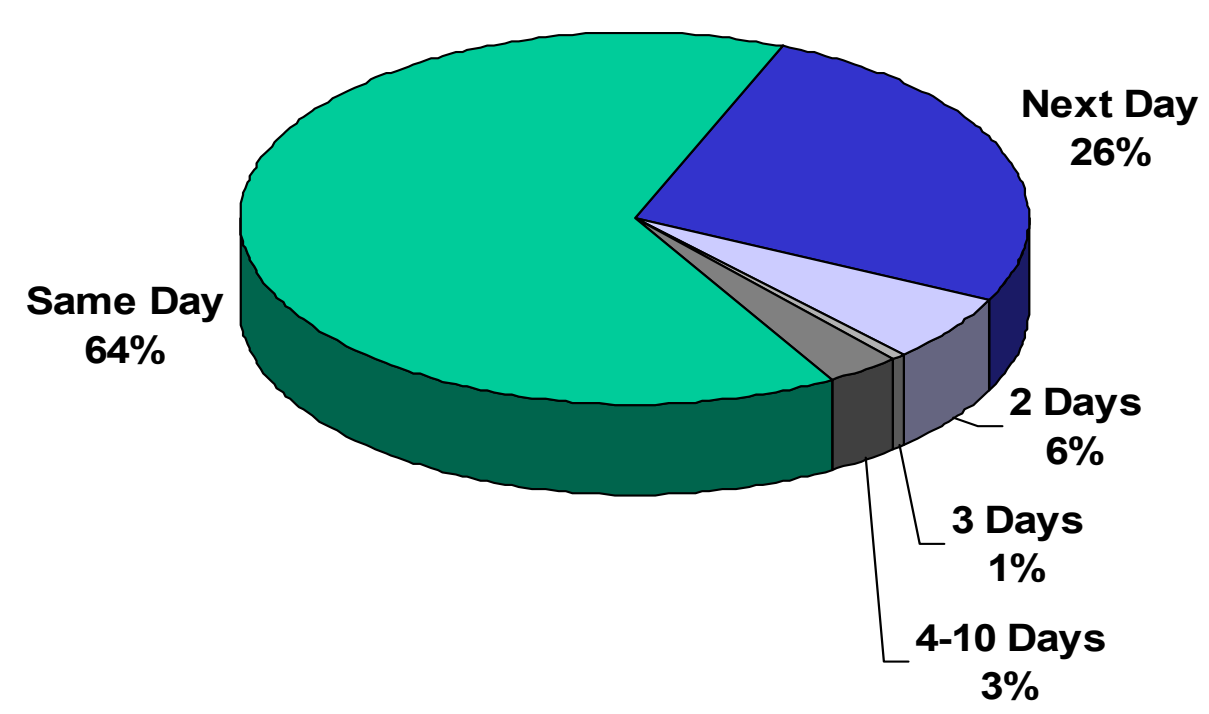

$\underline{2004}$

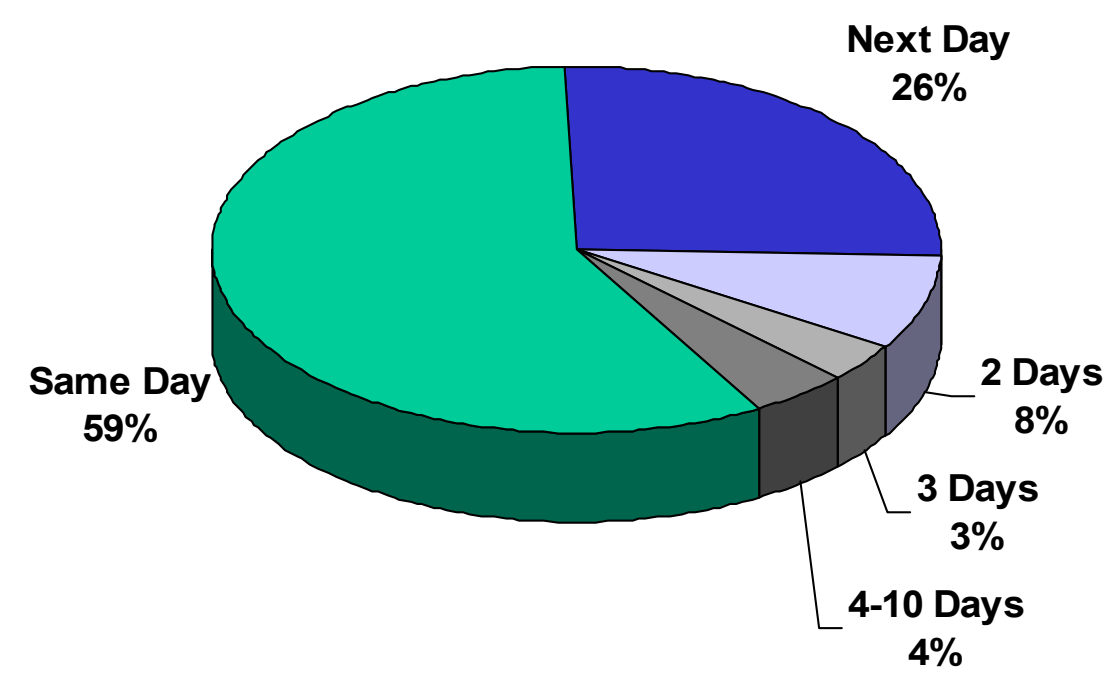




\section{EnergySmart Schools Product Distribution}

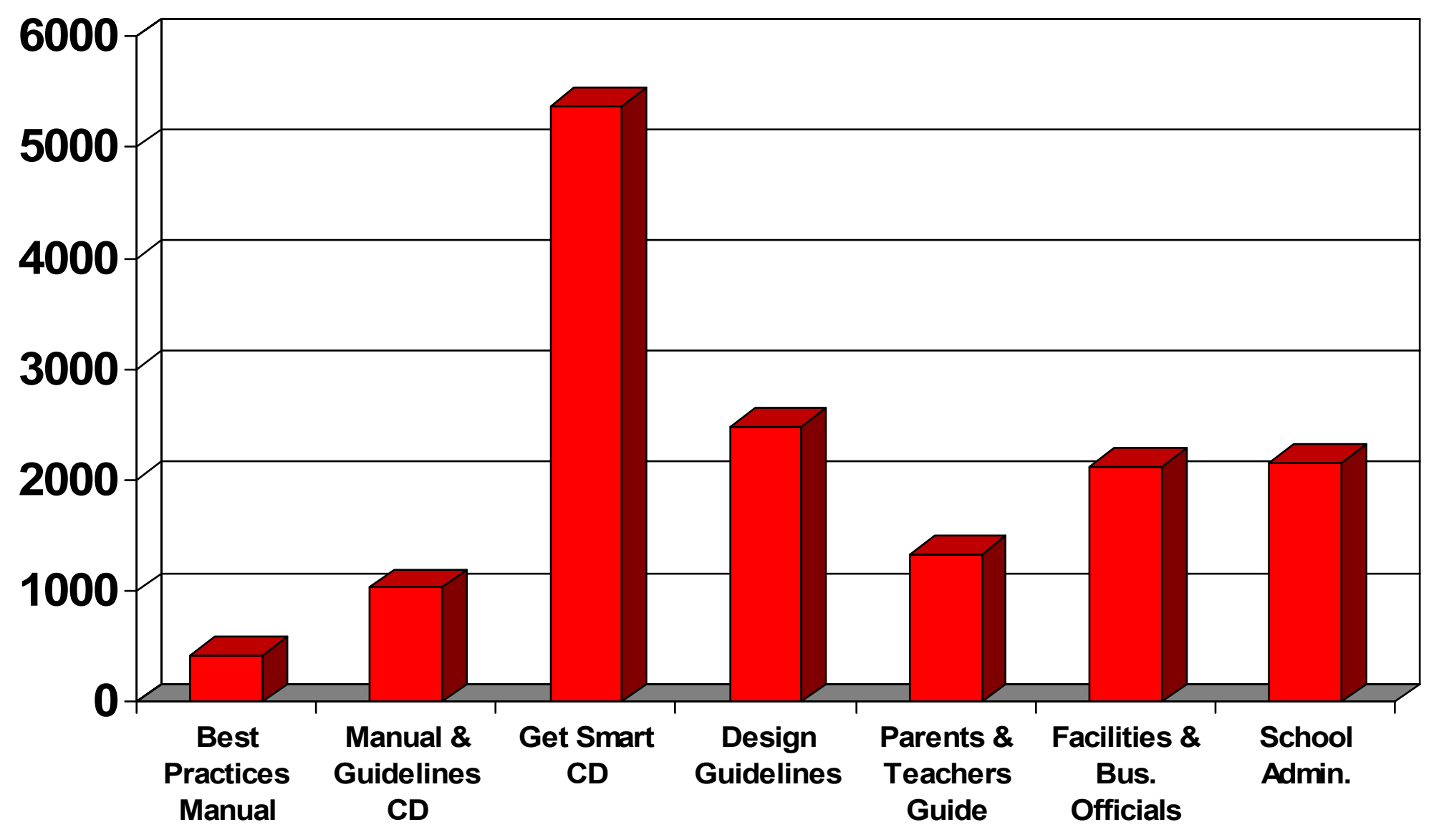




\section{HP Schools Design Guidelines Distribution}

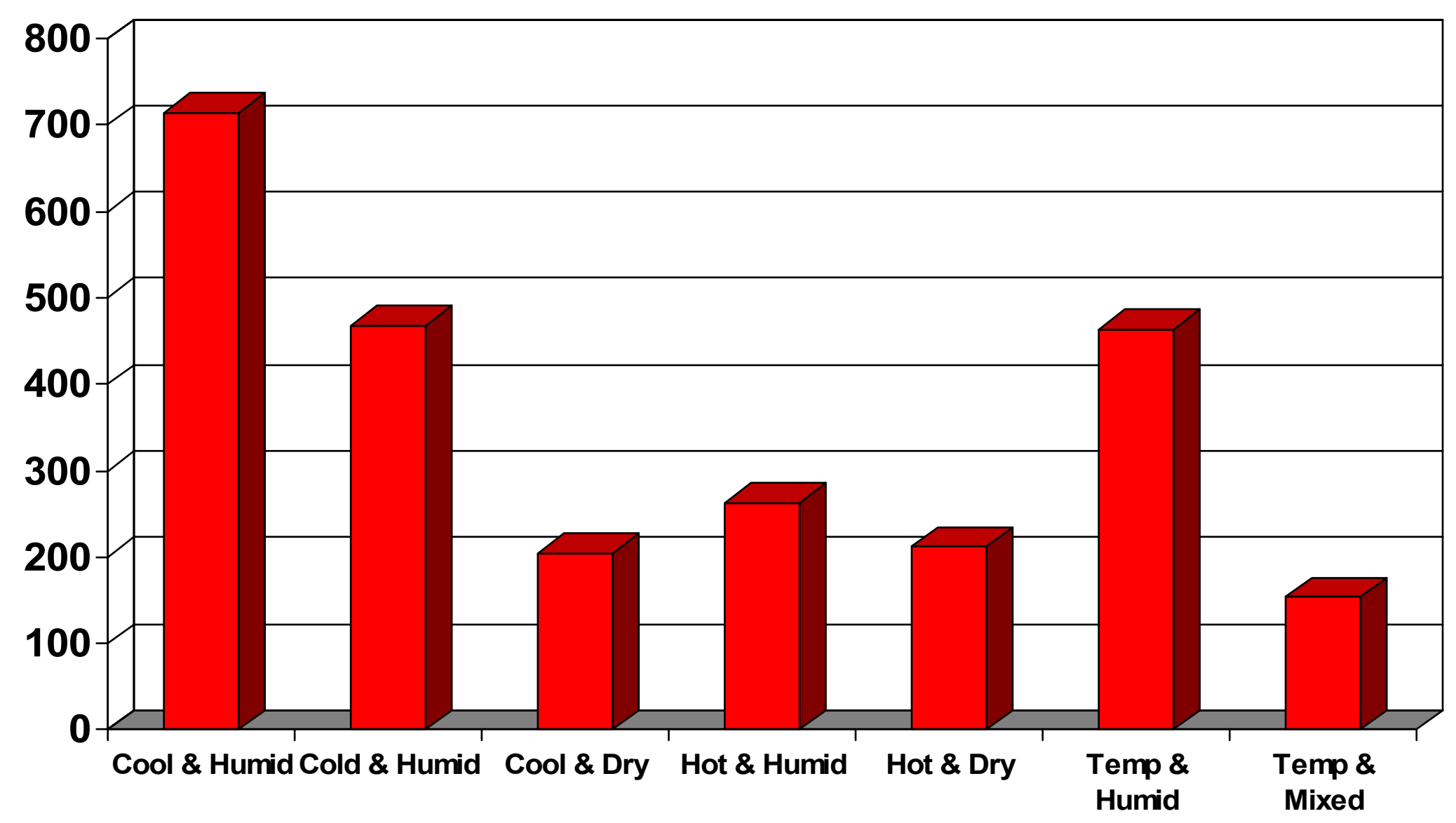




\section{FY 2004 BP Technology Seminars Summary}

- Number of Seminars: 24

- October to August 6

- Total Number of Participants: 1359

- Number of Business Partners Participating: 84

- Requests for More Information: 76

- Partnership or Business Partner 


\section{Business Partner Recruitment Status}

- 172 Total Partners

- 60 recommit

-112 new

- 139 have signed the DOE BP Agreement

- 142 created web profiles

- 134 have completed entire process

As of Sept 30, 2004 


\section{Company Distribution by Offered Technology}

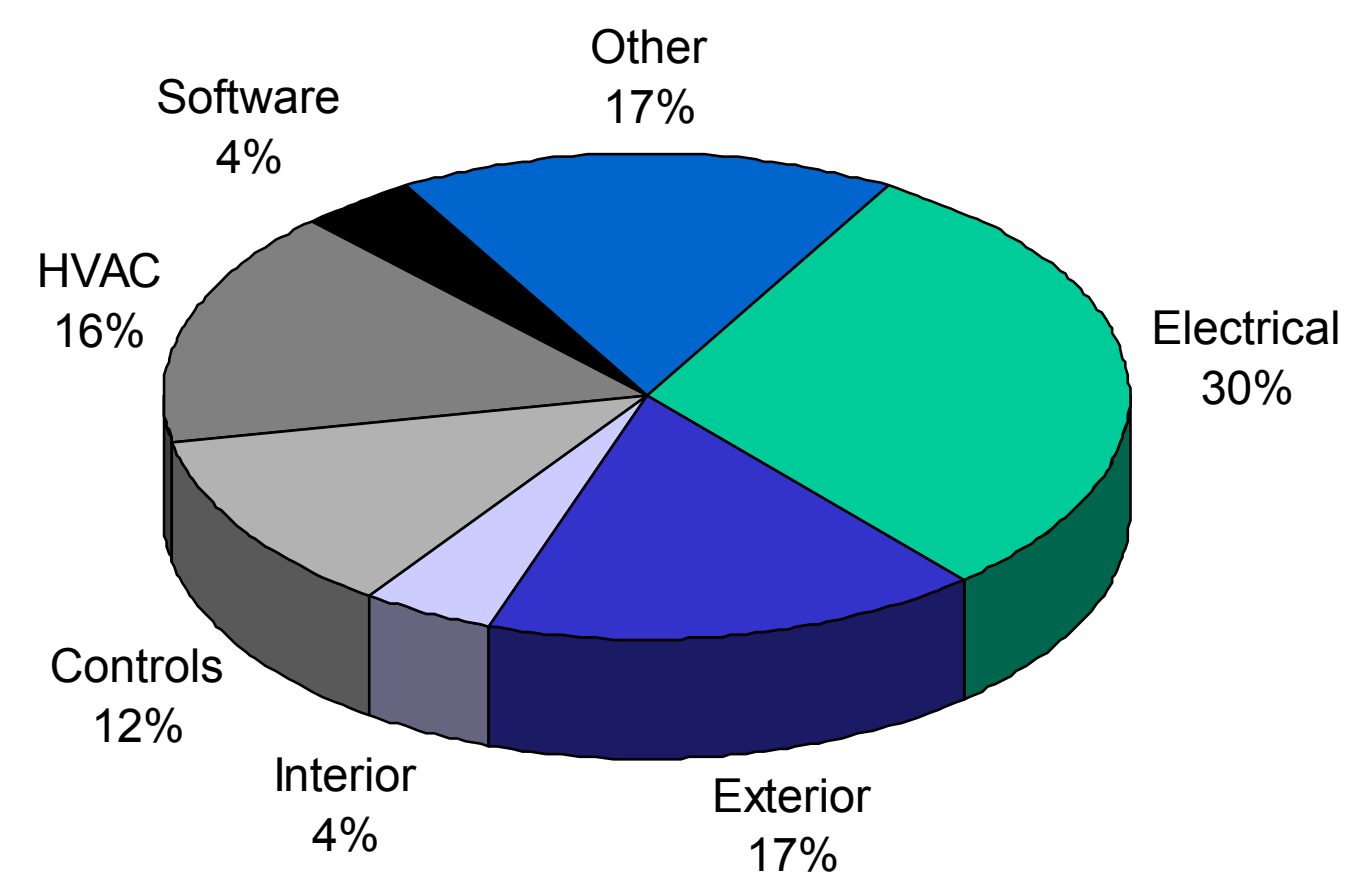




\section{Company Distribution by Offered Service}

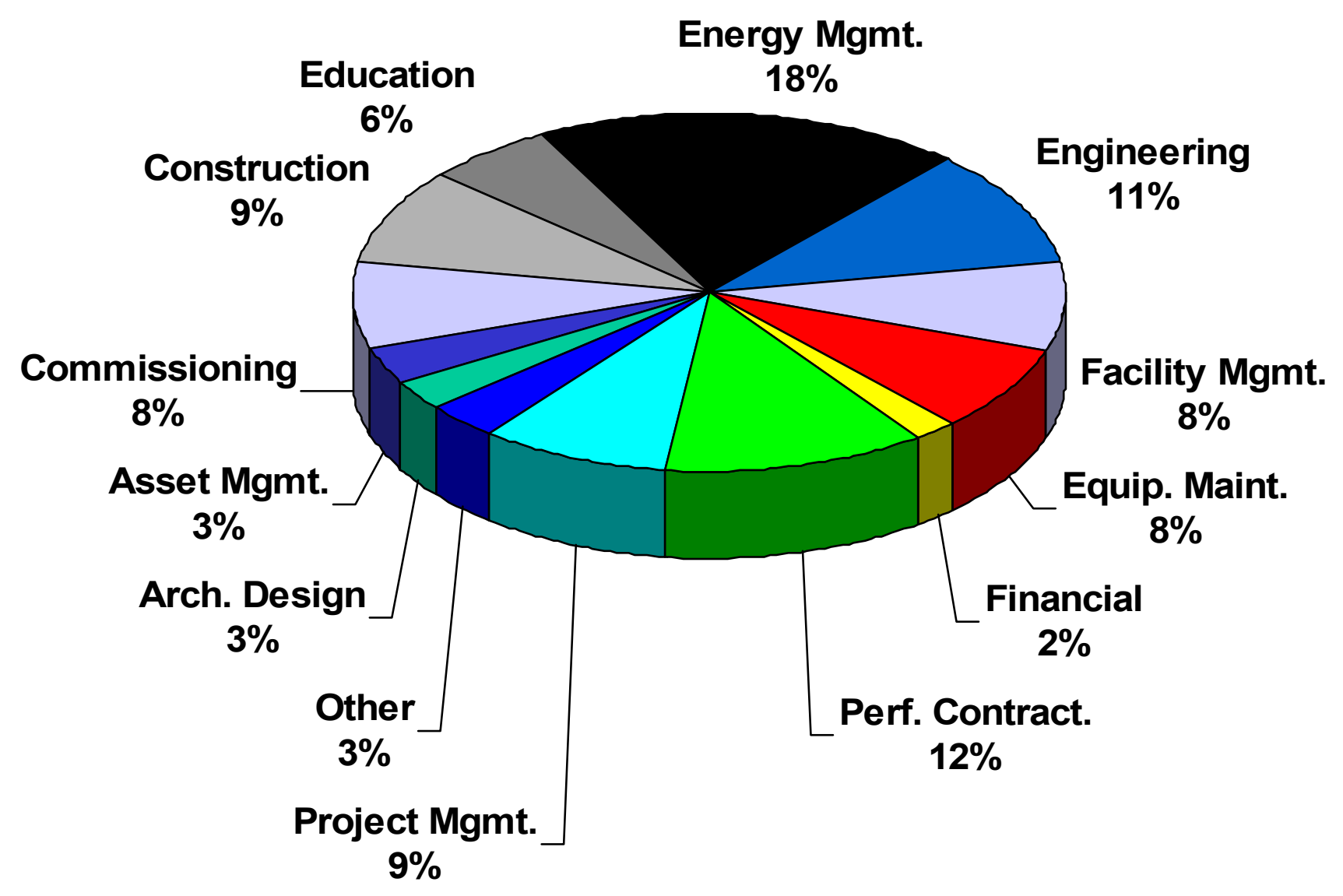




\section{Premier Business Partners}

\section{3}

- GE Lighting (lamps/lighting controls)

- Johnson Controls (building controls)

- Lithonia Lighting (lighting fixtures)

- McQuay International (chillers)

- NORESCO (energy services)

- OSRAM Sylvania (lamps/ballast)

- Sarnafil Roofing (roofing/waterproofing)

- Siemens (building controls/energy services)

- Traco (windows)

- Trane Company (chillers)

- WattStopper (lighting controls)
2004

-Acuity Brands Lighting (lighting fixtures)

-Earth Protection Services (waste management)

-EnLink Geoenergy Services (geothermal/mech.)

- GE Lighting (lamps/lighting controls)

- Johnson Controls (building controls)

-McQuay International (chillers)

-NORESCO (energy services)

-OSRAM Sylvania (lamps/ballast)

-Sarnafil Roofing (roofing/waterproofing)

-Siemens (building controls/energy services)

- Traco (windows)

- Trane Company (chillers)

-WattStopper (lighting controls) 


\section{Web Tasks Completed 2004}

- Updated new Project Assistance Center units with Business Partner Technology Energy Seminar and Professional Development request systems for approval, review, and delivery

- Deployed Success Story web/print content management feature added to distribute in Solution Center, Partnerships, and Market Sectors

- Key Metric Report Enhancements

New Regional Comparison report

New Executive Summary Snapshot report

New Market Sector progress report and CP progress reports

- Converted Site to comply with two versions of EERE Web Guidelines

- Upgraded new Business Partner Section presentation distribution on public side

- North Carolina State Energy USI Web site developed and deployed 


\section{Web Tasks Completed 2004 (continued)}

- Solution Center- 350 new information resources added

- Lawson System- system upgrade to provide greater system capability and more inventory reporting

- Integrated new upgraded listserv component for Flash Report/RBAzine email distribution

- Upgraded server database infrastructure to new SQL Server version to enhance security and prevent intrusion/hacking

- Moved site/database server with increased backup/redundancy features

- Added new Solution Center Search Advanced Search features based document tech level, market sector

- Added Business Partner Opportunity Posting system into Rebuild Network

- Implemented new structured BP products and services offerings into database and search feature 


\section{Rebuild America Web Site Hits}

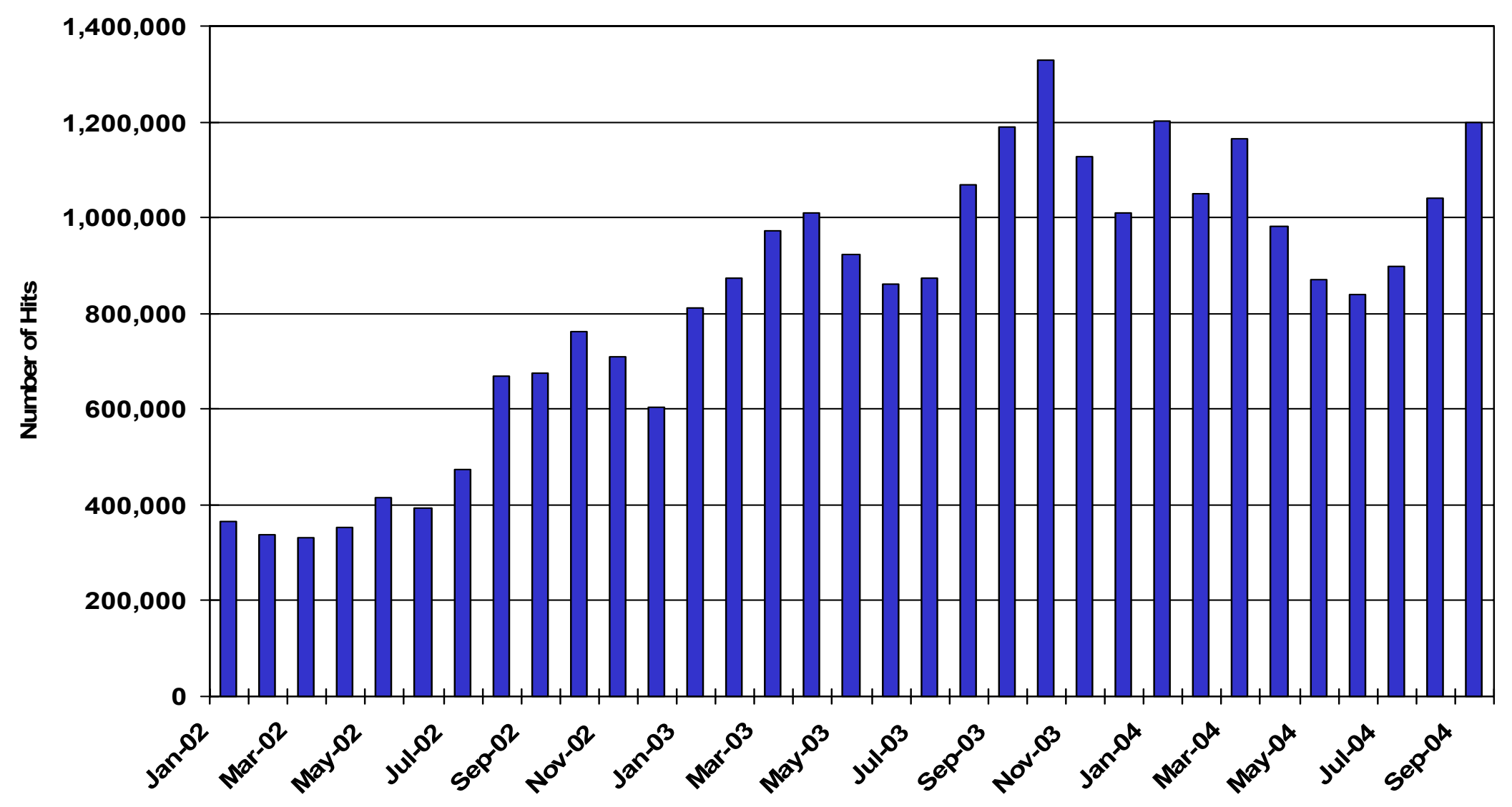




\section{Rebuild America Web Site Hits: Trend}

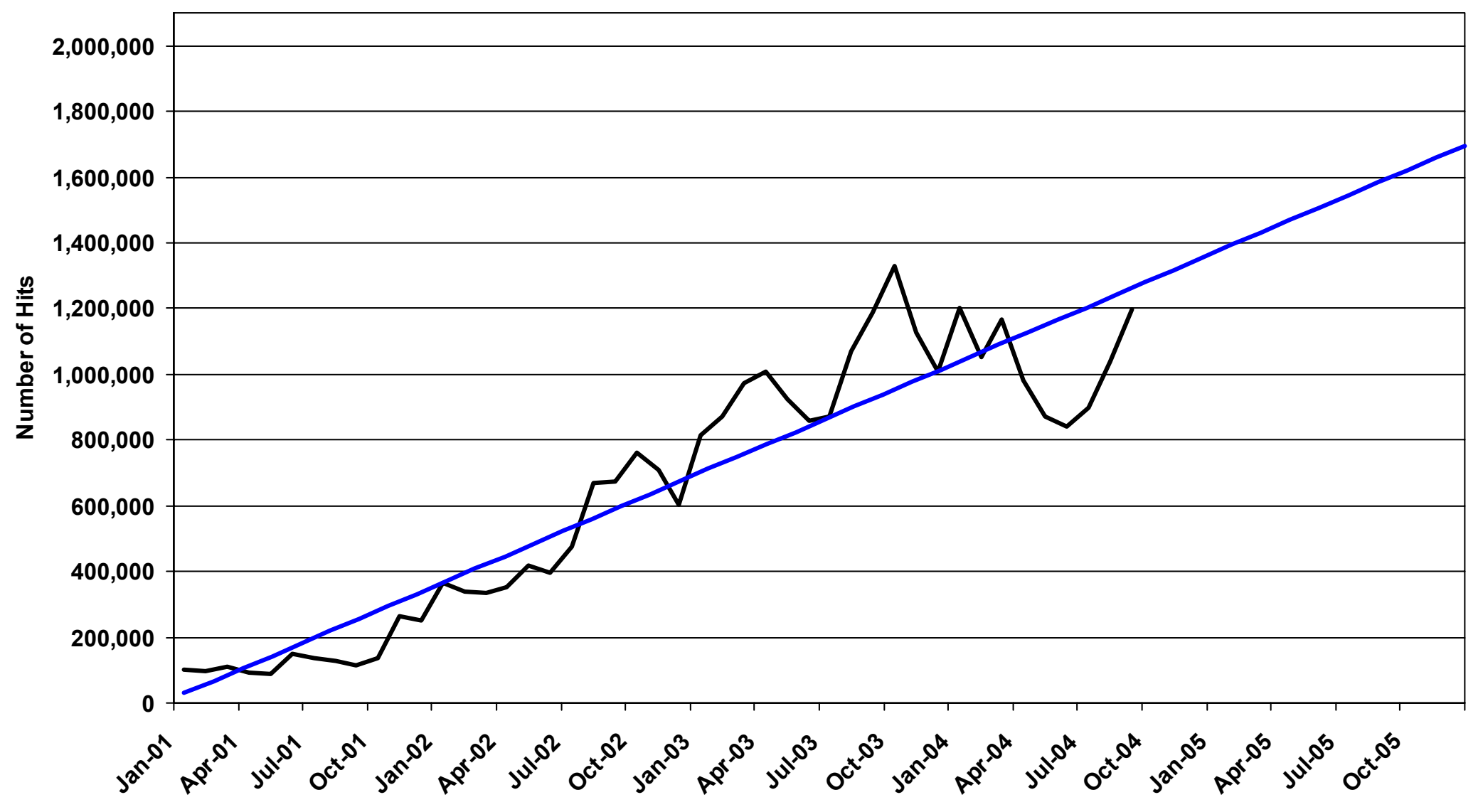




\section{Rebuild America Web Site Visitors}

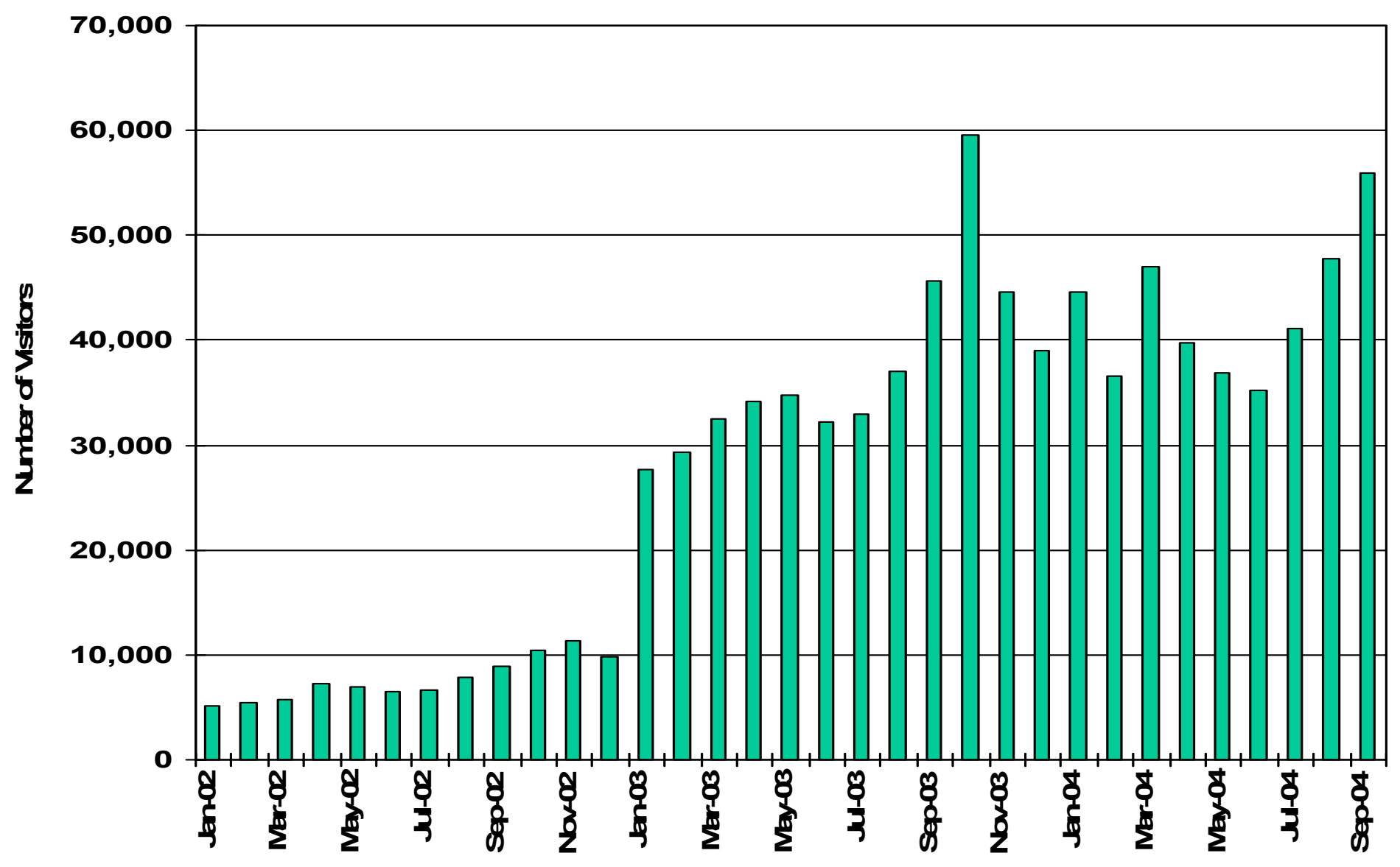




\section{Rebuild America Web Site Visitors: Trend}

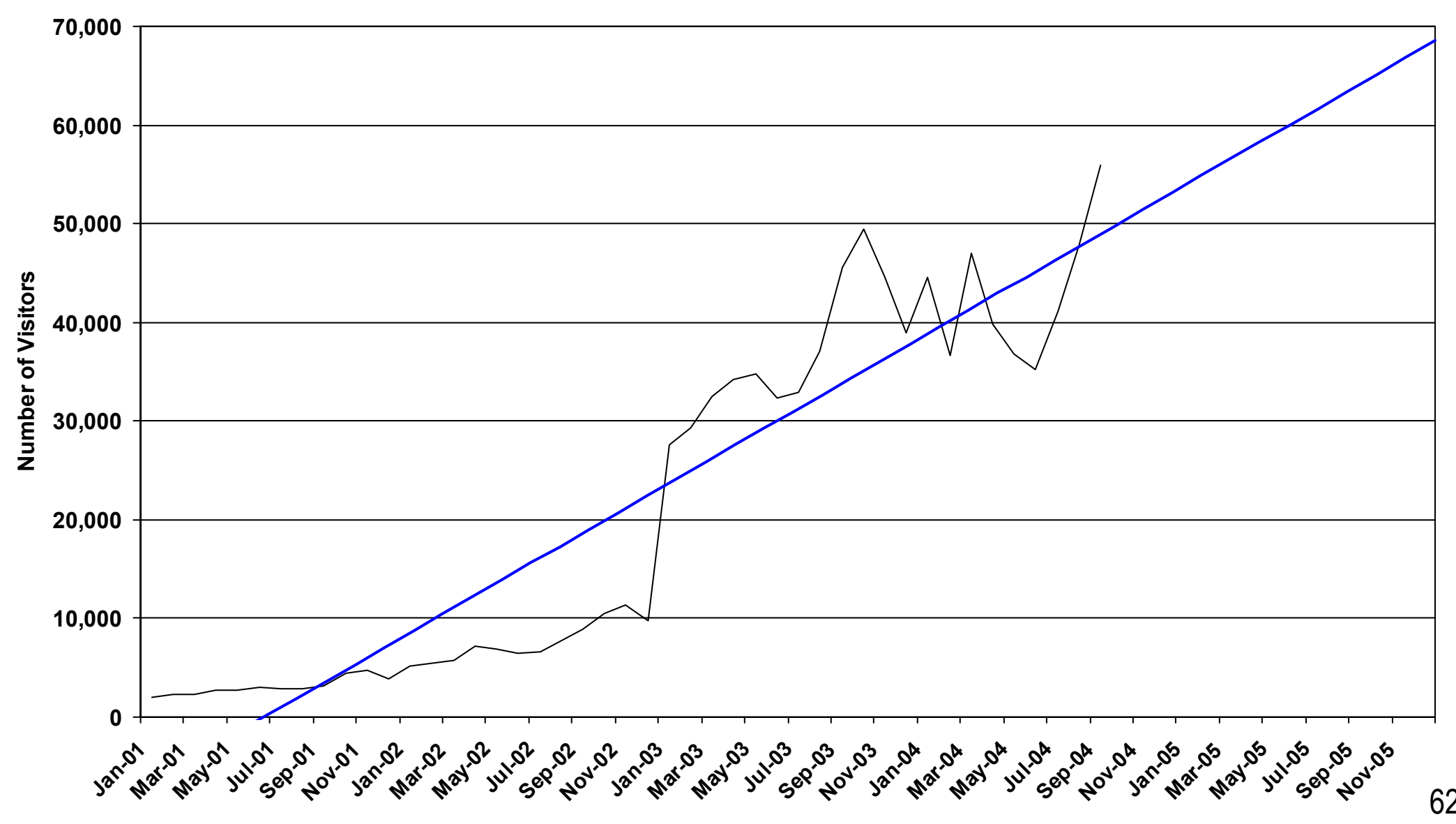




\section{Rebuild America Web Site Page Views}

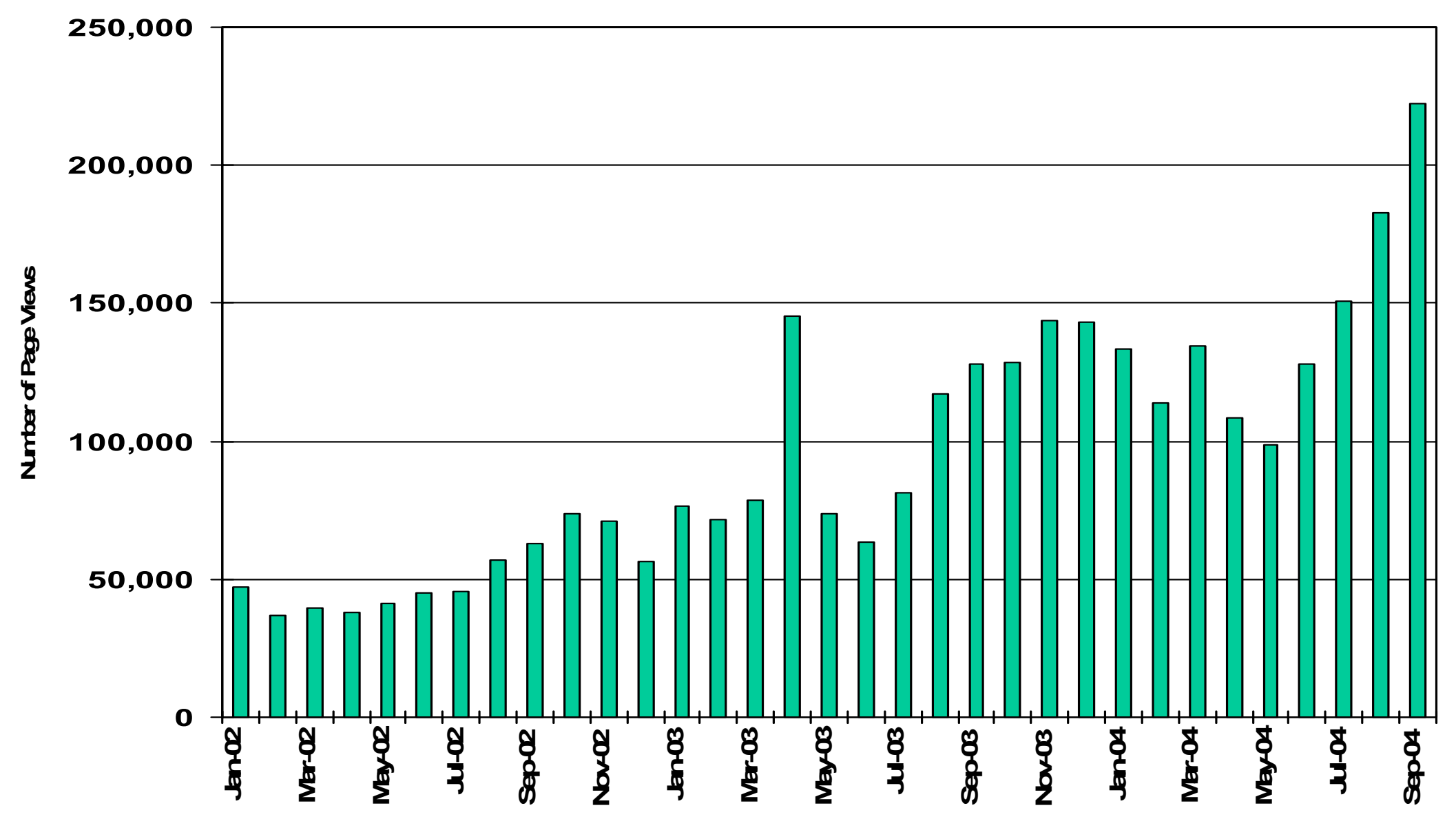




\section{Rebuild America Web Site Page Views: Trend}

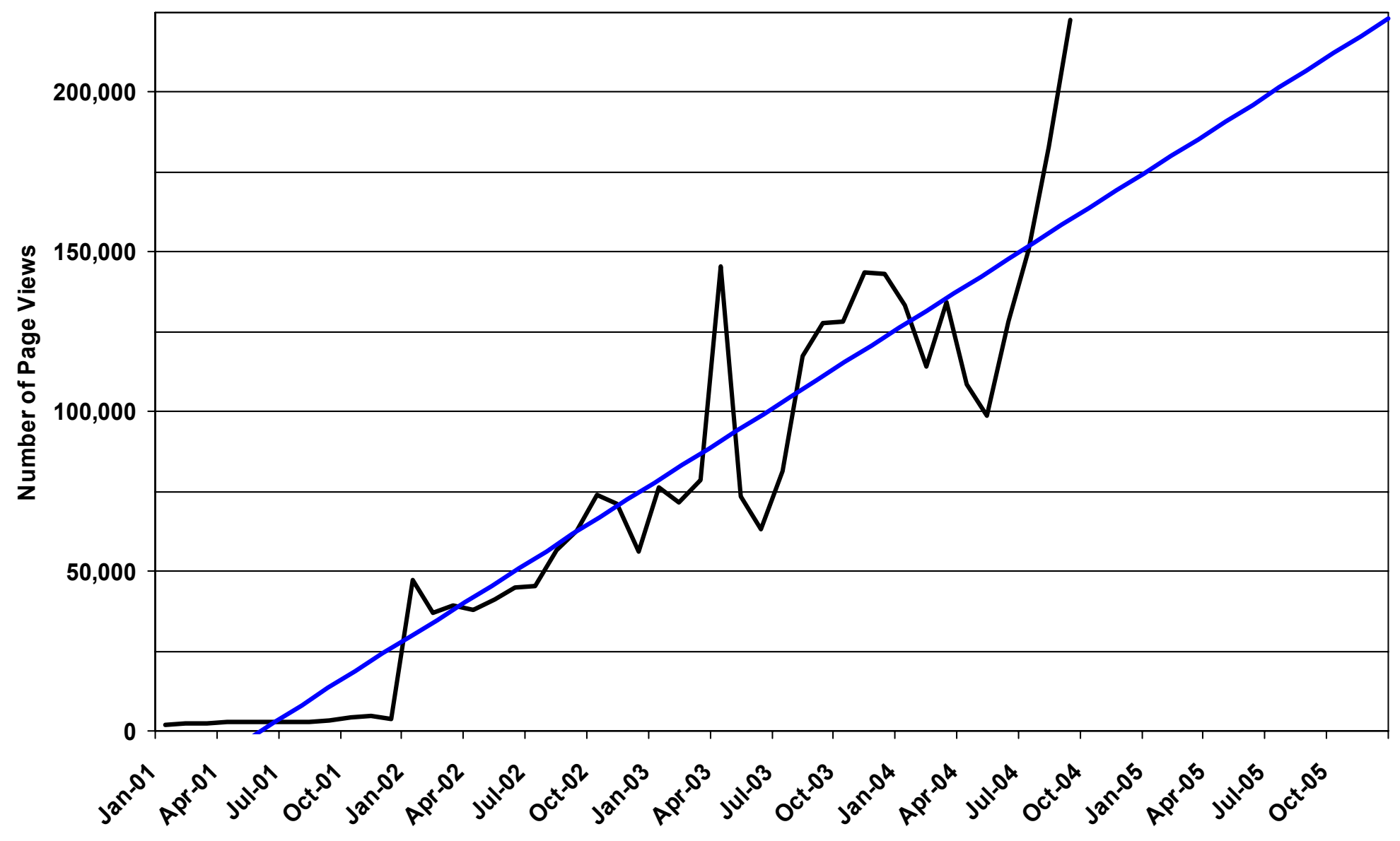




\section{APPENDIX D}

Rebuild America 2004:

Operational Plan and Deliverables Matrix 
U.S.DEPARTMENT OF ENERGY

\title{
REBUILD AMERICA
}

\author{
2004 \\ OPERATIONAL PLAN \\ And \\ DELIVERABLES MATRIX
}




\section{Executive Summary}

Rebuild America is a network of partnerships that implement projects and programs that focus on energy-related solutions to community problems. Rebuild America partnerships seek to use energy efficiency and renewable energy technologies to improve building performance while consuming less energy and generating less pollution. To that end, Rebuild America connects partnerships with technical assistance, tools, training and resources to help move projects from concept to completion.

The purpose of this 2004 Rebuild America Operational Plan is to define the specific "Actions" and "Deliverables" necessary to carry out the Rebuild America program Strategies as they relate to Goals and Objectives contained in the "2004 Draft Strategic Plan". In addition, this Operations Plan assigns responsibility for specific actions identified. Also, included as part of the "2004 Operations Plan" is the "2004 Deliverables Matrix" which more finitely articulates details related to the identified deliverables. This matrix focuses on specific outputs rather than processes based on the new Draft Strategic Plan.

This year the "Operational Plan" development process is more challenging because substantial changes have been made to the Strategic Plan that provides guidance on program goals, objectives and strategies. Although the revised Strategic Plan is still under review and could be revised to some extent, the planning cycle requires operational planning to begin prior to finalizing all elements of the Strategic Plan. This year there will also be an attempt to more closely link operational plan actions and deliverables with the specific strategies contained in the Strategic Plan. In addition, there is a results component included to capture and articulate results against expectations.

The overall effectiveness of the Rebuild America Operational Plan will ultimately be determined by the commitment of all the parties responsible for it to four underlying beliefs. These beliefs create the foundation on which this operational plan stands, and should be evident throughout the strategies, actions and deliverables herein:

1. The primary delivery points of Rebuild America are the EERE Regional Offices, and the State Energy Offices. These institutions must be provided with the funding, training, and administrative and technical support necessary to fully engage and support Partnerships and their projects.

2. The Program must collect accurate, complete, consistent, and relevant project and partnership data in order to effectively validate the impact of the program and quantify its value.

3. The program must continue to expand its core of well trained, professional field representatives to support the Partnerships' efforts and maintain the program's reputation for high quality, responsive service.

4. Industry and stakeholder groups provide valuable support in delivering many of the program's services. We will continue to look to the commercial marketplace, through these alliances and their projects, to accelerate the adoption of innovative technologies and practices. 


\section{Rebuild America 2004 Operational Plan}

\section{Strategic Goal \#1: Increase the Number of High-Performance Buildings}

1.1 Strategy: Develop and annually update regional implementation plans that include Square footage targets by market sector. Plans should include specific activities for recruiting and supporting partnerships and partners, and for delivering products and services by state and region.

\begin{tabular}{|c|c|c|c|c|}
\hline Task No. & Actions & Deliverables & Resp. & Status \\
\hline 1.1 .1 & Aspen to forecast and place square footage here. & $\begin{array}{l}\text { Assist with scheduled data collection efforts and } \\
\text { emphasize to states the importance of reporting } \\
\text { key metrics. } \\
\text { Assist the states of WI and IA with de- } \\
\text { aggregation of their metrics. }\end{array}$ & $\begin{array}{l}\text { CHI } \\
\text { REG }\end{array}$ & \\
\hline 1.1 .3 & $\begin{array}{l}\text { Help build and maintain the capacity of SEOs to } \\
\text { wholesale RBA, develop strong and sustainable } \\
\text { partnerships, and complete high-performance } \\
\text { building projects. }\end{array}$ & $\begin{array}{l}\text { Conduct two strategic planning meetings per } \\
\text { year with states and customer service reps to } \\
\text { prioritize and target the resources of DOE and } \\
\text { contractors. } \\
\text { For each of the eight states in the Chicago } \\
\text { Region, complete of a state profile, S.W.O.T } \\
\text { analysis, needs assessment, and contractor } \\
\text { action plans. }\end{array}$ & $\begin{array}{l}\text { CHI } \\
\text { REG }\end{array}$ & \\
\hline 1.1 .4 & $\begin{array}{l}\text { Provide four to six state partnerships with funds to } \\
\text { complete small projects to leverage local resources, } \\
\text { build their capacity, enhance or develop new } \\
\text { strategic and business partnerships, and implement } \\
\text { building projects. }\end{array}$ & $\begin{array}{l}\text { Complete four to six omnibus cooperative } \\
\text { agreements with states and monitor and report } \\
\text { on project progress }(\$ 40,000) \text {. }\end{array}$ & $\begin{array}{l}\text { CHI } \\
\text { REG }\end{array}$ & \\
\hline
\end{tabular}




\section{Strategic Goal \#1: Increase the Number of High-Performance Buildings}

\begin{tabular}{|c|c|c|c|}
\hline 1.1 .5 & $\begin{array}{l}\text { Develop 1 Plan for each Doe region that includes } \\
\text { "strategy" elements. }\end{array}$ & $\begin{array}{l}\text { Consolidate regional plans into one document } \\
\text { for distribution to RBA Program Manger and } \\
\text { regional Team Leaders }\end{array}$ & CS \\
\hline 1.1 .6 & $\begin{array}{l}\text { Develop background metrics data by region by } \\
\text { sector from May } 1,2001 \text { through December } 30, \\
2003 \text { containing annual average of results by sector. }\end{array}$ & $\begin{array}{l}\text { Provide report to each Regional Team Leader } \\
\text { and RBA Program Manager January 15, } 2004\end{array}$ & CS \\
\hline 1.1 .7 & $\begin{array}{l}\text { Provide state partnerships with funds to complete } \\
\text { small projects to leverage local resources, build their } \\
\text { capacity, enhance or develop new strategic and } \\
\text { business partnerships, and implement building } \\
\text { projects. }\end{array}$ & $\begin{array}{l}\text { Award omnibus cooperative agreements with } \\
\text { states and monitor and report on project progress } \\
(\$ 10,000) \text {. }\end{array}$ & $\begin{array}{l}\text { PHIL } \\
\text { REG }\end{array}$ \\
\hline 1.1 .8 & Forecast and place square footage here. & $\begin{array}{l}\text { Assist with scheduled data collection efforts and } \\
\text { emphasize to states the importance of reporting } \\
\text { key metrics. }\end{array}$ & $\begin{array}{l}\text { PHIL } \\
\text { REG }\end{array}$ \\
\hline 1.1 .9 & $\begin{array}{l}\text { Target organizations and sectors with high } \\
\text { probability to implement high-performance building } \\
\text { projects }\end{array}$ & $\begin{array}{l}\text { Expand the number of partnerships in DC } \\
\text { metropolitan area by developing and supporting } \\
\text { partnerships in the region. }(\$ 30,000) \text {. }\end{array}$ & $\begin{array}{l}\text { PHIL } \\
\text { REG }\end{array}$ \\
\hline 1.1 .10 & $\begin{array}{l}\text { Help build and maintain the capacity of SEOs to } \\
\text { wholesale RBA, develop strong and sustainable } \\
\text { partnerships, and complete high-performance } \\
\text { building projects. }\end{array}$ & $\begin{array}{l}\text { Conduct regional rep training workshop with } \\
\text { states and customer service reps }(\$ 10,000) \text {. }\end{array}$ & $\begin{array}{l}\text { PHIL } \\
\text { REG }\end{array}$ \\
\hline 1.1 .11 & $\begin{array}{l}\text { Regional Team Leads should identify } \\
\text { Perspective Market Sectors and priorities of } \\
\text { emphasis per region based on guidance from } \\
\text { National Program Mgr. and Strategic Plan. }\end{array}$ & $\begin{array}{l}\text { Each State determines priorities based on } \\
\text { guidance received from regions }\end{array}$ & CS \\
\hline 1.1 .12 & $\begin{array}{l}\text { Customer Service can be involved in fielding } \\
\text { priorities and training }\end{array}$ & $\begin{array}{l}\text { Customer Service provides modules of Rep } \\
\text { training utilizing the train-the-trainer concept. }\end{array}$ & CS \\
\hline 1.1 .13 & DOE Regional Office Support & $\begin{array}{l}\text { Fulfillment of assistance requests, materials } \\
\text { development, events, media, etc. in each region }\end{array}$ & M\&C \\
\hline
\end{tabular}




\section{Strategic Goal \#1: Increase the Number of High-Performance Buildings}

\begin{tabular}{|c|c|c|c|}
\hline 1.1 .14 & $\begin{array}{l}\text { Institute targeted effort to identify and support } \\
\text { building projects in the college and university sector. } \\
\text { Participate in Rebuild/APPA/NACUBO initiative. } \\
\text { Work with state representatives to identify projects } \\
\text { within each state. }\end{array}$ & 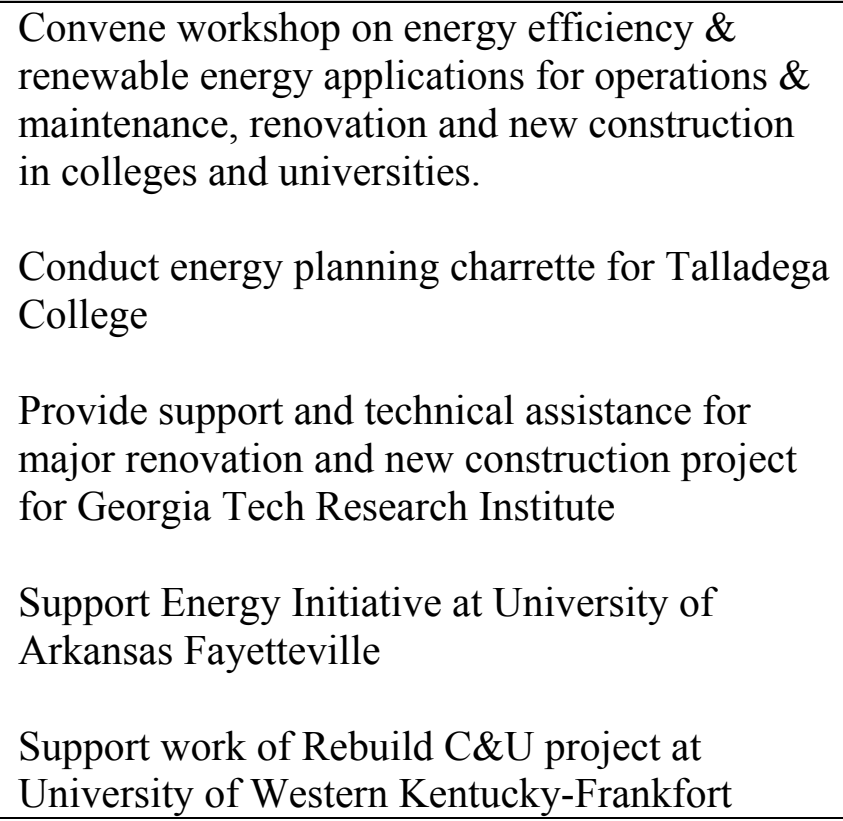 & $\begin{array}{l}\text { ATL } \\
\text { REG }\end{array}$ \\
\hline 1.1 .15 & Develop Regional Plan Jan. 15, 2004 & Regional Plan & $\begin{array}{l}\text { DEN } \\
\text { REG }\end{array}$ \\
\hline 1.1 .16 & Forecast and Square Footage & $\begin{array}{l}\text { Assist data collection with State and two Aspen } \\
\text { Reps. Stress the importance of reporting key } \\
\text { metrics. Document the accomplishments of } \\
\text { partnerships with up-to-date data collection. }\end{array}$ & $\begin{array}{l}\text { SEA } \\
\text { REG }\end{array}$ \\
\hline 1.1 .17 & $\begin{array}{l}\text { Target organizations and sectors with high } \\
\text { probability to implement high-performance building } \\
\text { projects }\end{array}$ & $\begin{array}{l}\text { Support and maintain existing partnerships } \\
\text { through continued quality services, } \\
\text { communication, training and technical } \\
\text { assistance, recognition, planning assistance. } \\
\text { Keep partnerships motivated to implement } \\
\text { energy efficiency improvements in facilities and } \\
\text { to implement new projects. }\end{array}$ & $\begin{array}{l}\text { SEA } \\
\text { REG }\end{array}$ \\
\hline
\end{tabular}




\section{Strategic Goal \#1: Increase the Number of High-Performance Buildings}

\begin{tabular}{|c|l|l|l|}
\hline \multirow{3}{*}{1.1 .18} & $\begin{array}{l}\text { Help build and maintain the capacity of SEOs to } \\
\text { wholesale RBA, develop strong and sustainable } \\
\text { partnerships, and complete high-performance } \\
\text { building projects. }\end{array}$ & $\begin{array}{l}\text { : Hold meetings, workshops, trainings for state } \\
\text { reps and partnerships. Focus areas may include } \\
\text { energy efficiency retrofits, high performance } \\
\text { standards for new and existing high performance } \\
\text { buildings, Green Building Design, Resource } \\
\text { Conservation Programs. }\end{array}$ & $\begin{array}{l}\text { SEA } \\
\text { REG }\end{array}$ \\
\hline
\end{tabular}

1.2 Strategy: Continue to build and maintain state networks for marketing the program and delivering services to partnerships, fostering a strong relationship with the National Association of State Energy Officials (NASEO)

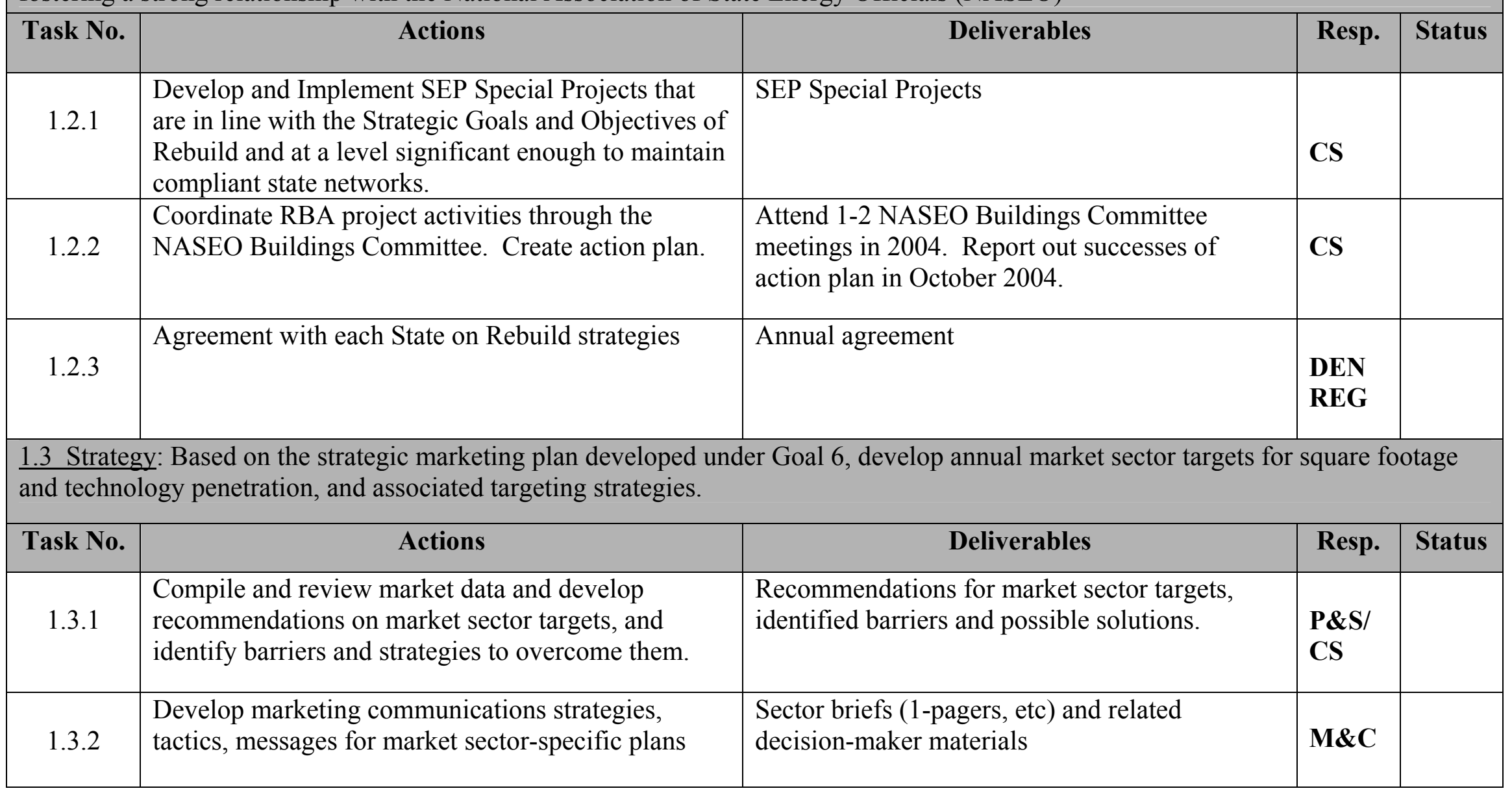




\section{Strategic Goal \#1: Increase the Number of High-Performance Buildings}

\begin{tabular}{|c|c|c|c|c|}
\hline 1.3 .3 & Within Regional Plan develop market sector goals. & Square footage targets for this market sector. & $\begin{array}{l}\text { DEN } \\
\text { REG }\end{array}$ & \\
\hline$\frac{t \text { Strate }}{\text { gular ba }}$ & Identify, confirm, and & es. & & \\
\hline Task No. & Actions & Deliverables & Resp. & Status \\
\hline 1.4 .1 & $\begin{array}{l}\text { Customer service reps in the Chicago region will } \\
\text { work with states to report metrics and to de- } \\
\text { aggregate data where appropriate. }\end{array}$ & $\begin{array}{l}\text { All eight states in the Chicago Region report } \\
\text { metrics as requested. }\end{array}$ & $\begin{array}{l}\text { CHI } \\
\text { REG }\end{array}$ & \\
\hline 1.4 .2 & $\begin{array}{l}\text { Capture RBA metrics data on a quarterly basis } \\
\text { consistent with DOE Program Manager Program } \\
\text { Performance reporting requirements }\end{array}$ & $\begin{array}{l}\text { Provide RBA Program Manager with Program } \\
\text { metrics "Executive Summary" quarterly }\end{array}$ & CS & \\
\hline 1.4 .3 & $\begin{array}{l}\text { Develop and present annual RBA program } \\
\text { Performance Report on Metrics and Program trends }\end{array}$ & $\begin{array}{l}\text { Annual Program Report Submitted to RBA } \\
\text { Program Manager November } 20,2004 \text {. }\end{array}$ & CS & \\
\hline 1.4 .4 & $\begin{array}{l}\text { Encourage and assist states and partnerships to report } \\
\text { metrics. }\end{array}$ & $\begin{array}{l}\text { States and partnerships report metrics as } \\
\text { requested. }\end{array}$ & $\begin{array}{l}\text { PHIL } \\
\text { REG }\end{array}$ & \\
\hline 1.4 .5 & $\begin{array}{l}\text { Capture RBA metrics data on a quarterly basis } \\
\text { consistent with DOE Program Manager Program } \\
\text { Performance reporting requirements }\end{array}$ & $\begin{array}{l}\text { Provide RBA Program Manager with Program } \\
\text { metrics "Executive Summary" quarterly }\end{array}$ & P\&S & \\
\hline 1.4 .6 & $\begin{array}{l}\text { Develop and present annual RBA program } \\
\text { Performance Report on Metrics and Program trends }\end{array}$ & $\begin{array}{l}\text { Annual Program Report Submitted to RBA } \\
\text { Program Manager November 20, } 2004 \text {. }\end{array}$ & P\&S & \\
\hline 1.4 .7 & $\begin{array}{l}\text { Support periodic reporting requirements through data } \\
\text { collection efforts whether bi-annually, quarterly, or } \\
\text { monthly. }\end{array}$ & $\begin{array}{l}\text { Utilizing Win-Saga, web-site delivery, project } \\
\text { tracking, personal contact thru phone con, e- } \\
\text { mail, or field visits to gather data and provide } \\
\text { support for collection efforts. }\end{array}$ & CS & \\
\hline
\end{tabular}




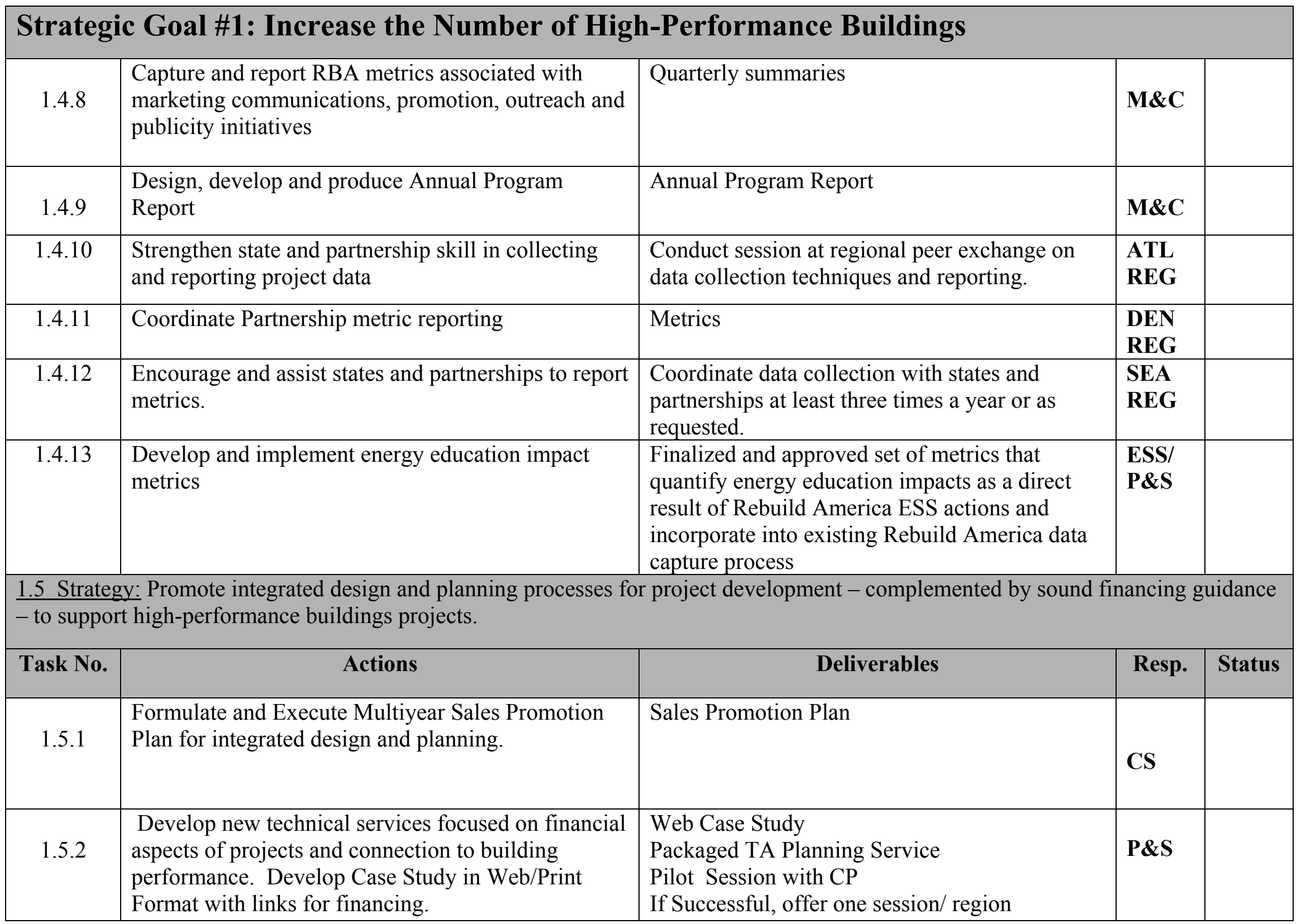




\section{Strategic Goal \#1: Increase the Number of High-Performance Buildings}

\begin{tabular}{|c|c|c|c|}
\hline 1.5 .3 & $\begin{array}{l}\text { Feature integrated design and planning processes and } \\
\text { financing strategies in ongoing communications } \\
\text { outreach to partnerships and partner reps; promote } \\
\text { opportunities through strategic partner networks }\end{array}$ & $\begin{array}{l}\text { By-lined article in strategic partner publications, } \\
\text { success stories, Update newsletter, exhibit } \\
\text { collaterals, presentation module }\end{array}$ & M\&C \\
\hline 1.5 .4 & Ensure complete awareness of Rebuild resources. & $\begin{array}{l}\text { Inform each project partner of design and } \\
\text { finance resource. }\end{array}$ & $\begin{array}{l}\text { DEN } \\
\text { REG }\end{array}$ \\
\hline 1.5 .5 & $\begin{array}{l}\text { Analyze correlation between "Design Guidelines" } \\
\text { and LEED }\end{array}$ & $\begin{array}{l}\text { Analysis report with recommendations } \\
\text { correlating "High Performance Schools } \\
\text { Guidelines" and LEED rating certification }\end{array}$ & ESS \\
\hline
\end{tabular}

1.6 Strategy: Work proactively with communities that are considering or pursuing major redevelopment initiatives to ensure the inclusion of energy-efficiency technologies and designs.

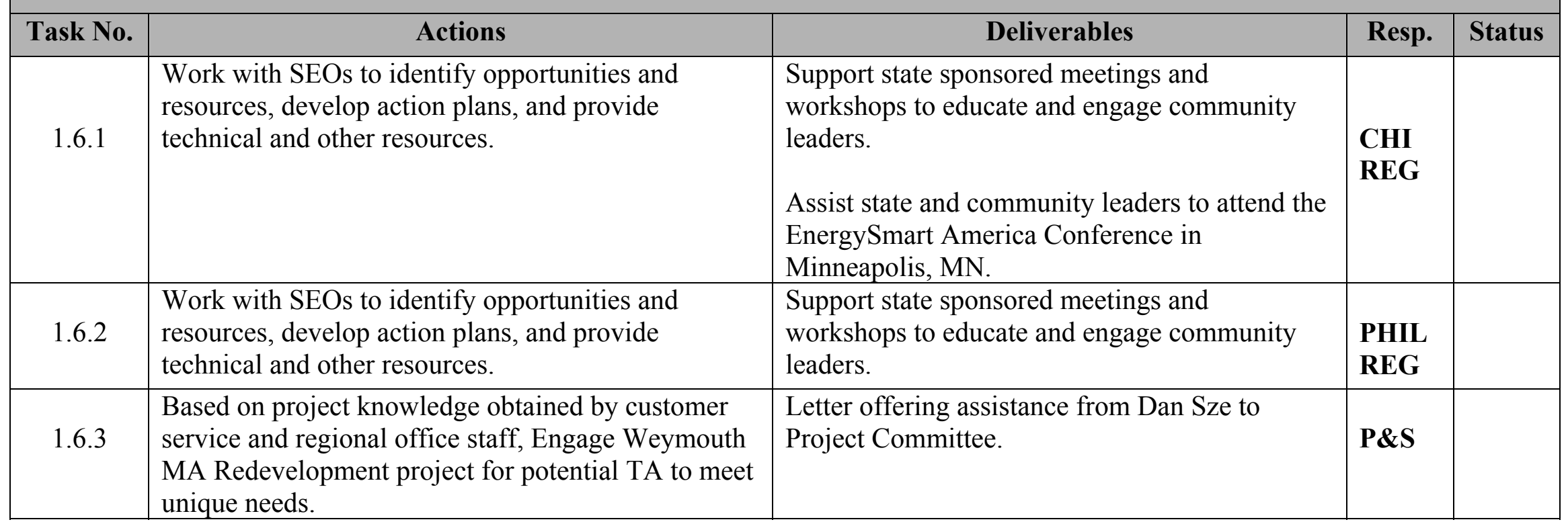




\begin{tabular}{|c|l|l|l|}
\hline \multicolumn{2}{|c|}{ Strategic Goal \#1: Increase the Number of High-Performance Buildings } \\
\hline 1.6 .4 & $\begin{array}{l}\text { Work with states, business and strategic partners to } \\
\text { identify project. }\end{array}$ & $\begin{array}{l}\text { Participate in design charrette for Murdock } \\
\text { Village Project, Charlotte County Florida } \\
\text { Conduct presentation for Chatham County, GA } \\
\text { officials on Rebuild resources for major building } \\
\text { project. }\end{array}$ & $\begin{array}{l}\text { ATL } \\
\text { REG }\end{array}$ \\
\hline 1.6 .5 & $\begin{array}{l}\text { Coordinate EE technology information for } \\
\text { communities. }\end{array}$ & $\begin{array}{l}\text { Redevelopment project strategy to include EE } \\
\text { technologies. }\end{array}$ & $\begin{array}{l}\text { DEN } \\
\text { REG }\end{array}$ \\
\hline 1.6 .6 & $\begin{array}{l}\text { Work with SEOs to identify opportunities and } \\
\text { resources, develop action plans, and provide } \\
\text { technical and other resources. }\end{array}$ & $\begin{array}{l}\text { Support state-sponsored meetings and } \\
\text { workshops. Provide technical assistance and } \\
\text { funding as available. }\end{array}$ & $\begin{array}{l}\text { SEA } \\
\text { REG }\end{array}$ \\
\hline 1.6 .7 & $\begin{array}{l}\text { Showcase redevelopment initiatives and promote } \\
\text { lessons learned. }\end{array}$ & $\begin{array}{l}\text { Success stories and presentation modules, } \\
\text { highlighting use of EE technologies }\end{array}$ & M\&C \\
\hline
\end{tabular}




\section{Strategic Goal \#2 : Provide Tailored Customer Assistance Through a Competent, Professional Team of Program Representatives}

2.1 Strategy: Ensure that each program representative has a toolbox of marketing and media materials, guidance, and easy access to marketing and publicity services in support of partnership activities.

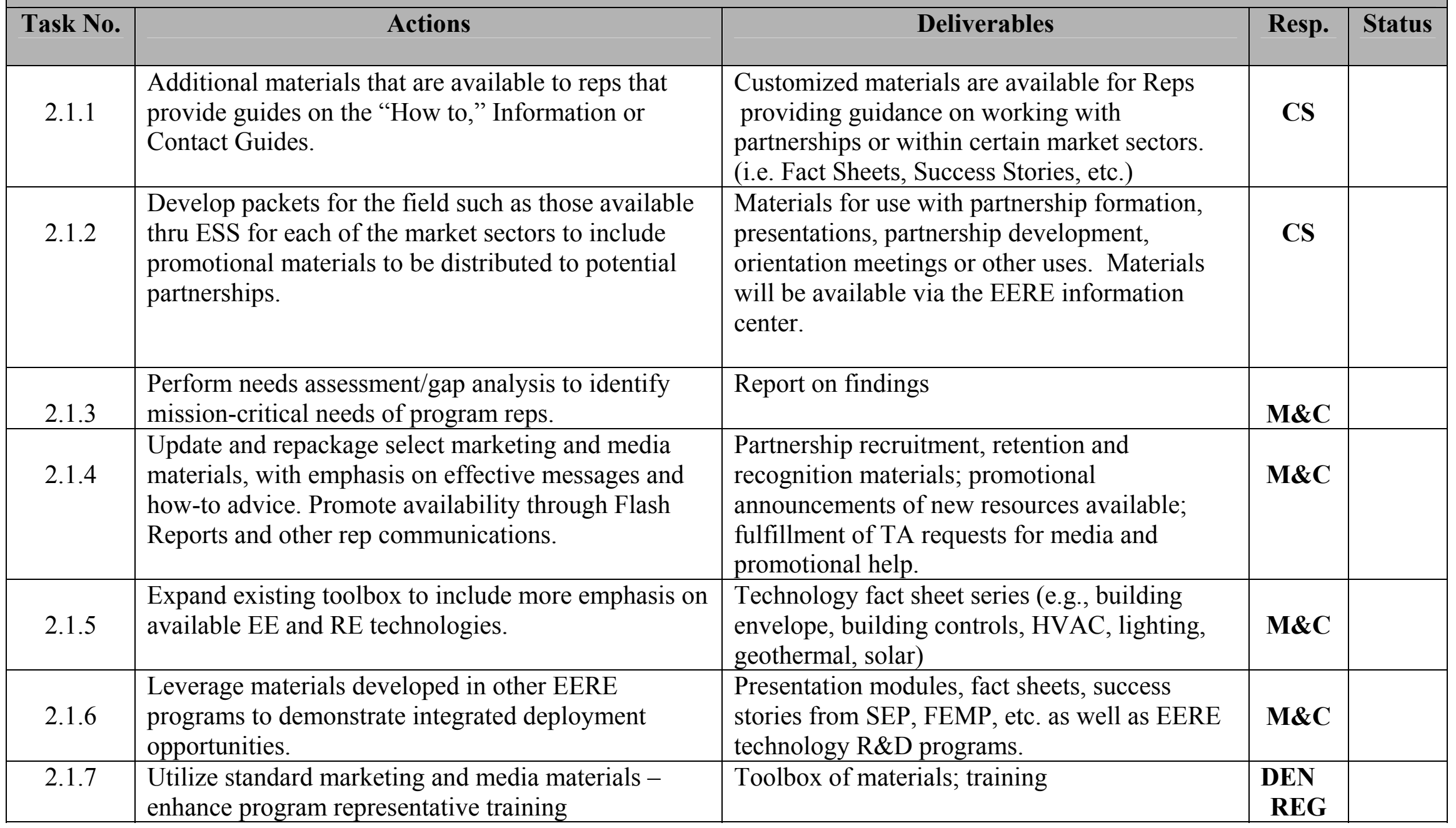




\section{Strategic Goal \#2 : Provide Tailored Customer Assistance Through a Competent, Professional Team of Program Representatives}

2.2 Strategy: Recruit staff from selected Strategic Partners and Business Partners to serve as program representatives for partnerships formed by their members.

\begin{tabular}{|c|c|c|c|c|}
\hline Task No. & Actions & Deliverables & Resp. & Status \\
\hline 2.2 .2 & Support rep recruitment and training. & $\begin{array}{l}\text { Recruitment and training presentation modules; } \\
\text { statements on program value from Strategic and } \\
\text { Business Partners }\end{array}$ & $\mathbf{M \& C}$ & \\
\hline \multicolumn{5}{|c|}{$\begin{array}{l}\text { 2.3 Strategy: Using benchmarking or other appropriate methods, develop standards and collect and report measurements of customer } \\
\text { service timeliness and effectiveness. }\end{array}$} \\
\hline Task No. & Actions & Deliverables & Resp. & Status \\
\hline 2.3 .1 & $\begin{array}{l}\text { 1. Define Major Categories Of Customer Service } \\
\text { Activity. } \\
\text { 2. Collect input for program's customers on } \\
\text { important areas of CS focus and ideas on how to } \\
\text { measure their effectiveness. } \\
\text { 3. Establish Parameters For Timeliness \& } \\
\text { Definitions Of Effectiveness. } \\
\text { 4. Develop Norms For Each Major Category. } \\
\text { Design \& Implement Reporting \&/or Monitoring } \\
\text { Regime. }\end{array}$ & $\begin{array}{l}\text { Report and recommendations on measures of } \\
\text { effectiveness. }\end{array}$ & CS & \\
\hline 2.3 .2 & $\begin{array}{l}\text { Review of PAC TA Requests- set process standards } \\
\text { for processing, close-out of requests. }\end{array}$ & $\begin{array}{l}\text { Monthly Report for PS/ CS leads, and Team } \\
\text { Leaders of results. }\end{array}$ & P\&S & \\
\hline
\end{tabular}




\begin{tabular}{|c|c|c|c|c|}
\hline \multicolumn{5}{|c|}{$\begin{array}{l}\text { Strategic Goal \#2 : Provide Tailored } \\
\text { Team of Program Representatives }\end{array}$} \\
\hline 2.3 .3 & $\begin{array}{l}\text { Review work plans, monthly reports, assessment of } \\
\text { Program Staff, Regional Team Leads, Customer } \\
\text { Service Mgr., Market Sectors, Products \& Service, } \\
\text { for key skill sets and evaluation of services and to } \\
\text { determine audit/assessment mechanism. }\end{array}$ & $\begin{array}{l}\text { Conduct assessment annually (at a minimum) } \\
\text { and provide results to key individuals. }\end{array}$ & CS & \\
\hline Task No. & Actions & Deliverables & Resp. & Status \\
\hline 2.4 .1 & $\begin{array}{l}\text { Assist SEO and key local partnerships to obtain } \\
\text { training. Encourage the use of Web-based training } \\
\text { tools to eliminate travel barriers. }\end{array}$ & $\begin{array}{l}\text { Training and peer mentoring for state and local } \\
\text { program reps in the region }(\$ 5,000) \text {. }\end{array}$ & $\begin{array}{l}\text { CHI } \\
\text { REG }\end{array}$ & \\
\hline 2.4 .4 & $\begin{array}{l}\text { Contribute training appropriate for training reps on } \\
\text { current and emerging technologies. }\end{array}$ & $\begin{array}{l}\text { Modules for currents and emerging } \\
\text { technologies. }\end{array}$ & P\&S & \\
\hline 2.4 .5 & $\begin{array}{l}\text { Review and Identify key skill sets or competencies } \\
\text { needed by reps, specific training areas and objectives, } \\
\text { identify key trainers and availability, possible types } \\
\text { of training and venues, initial target of trainings or } \\
\text { training opportunities and initial reps to be trained as } \\
\text { well as how to sustain training. }\end{array}$ & $\begin{array}{l}\text { Develop Modules of Training } \\
\text { Provide Training at least yearly as a stand alone } \\
\text { or in conjunction with other events. } \\
\text { Utilize a Train the Trainer Concept for } \\
\text { Sustainability or to train other Reps. } \\
\text { Evaluate success of training by surveys to gain } \\
\text { feedback and field reports. }\end{array}$ & CS & \\
\hline
\end{tabular}




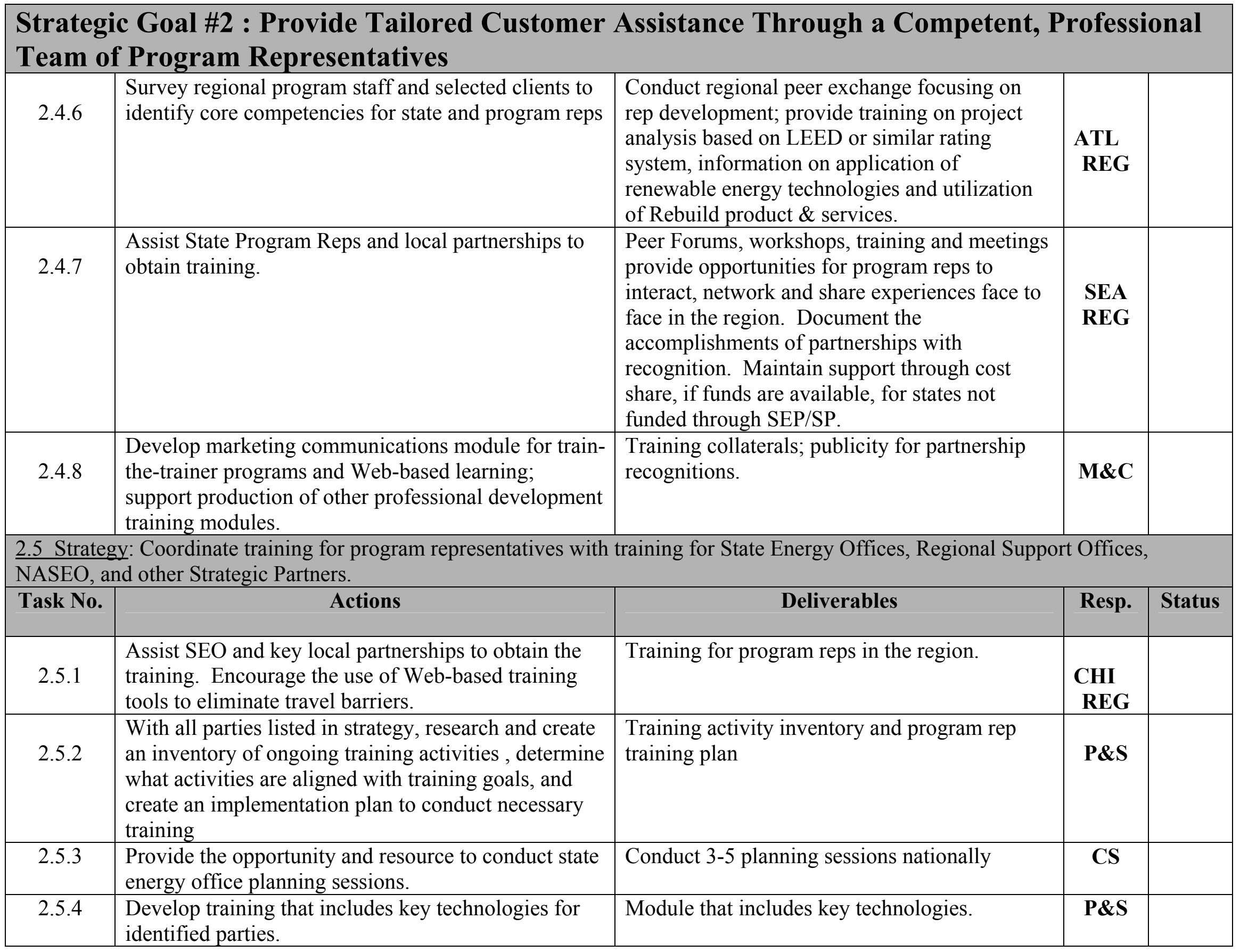




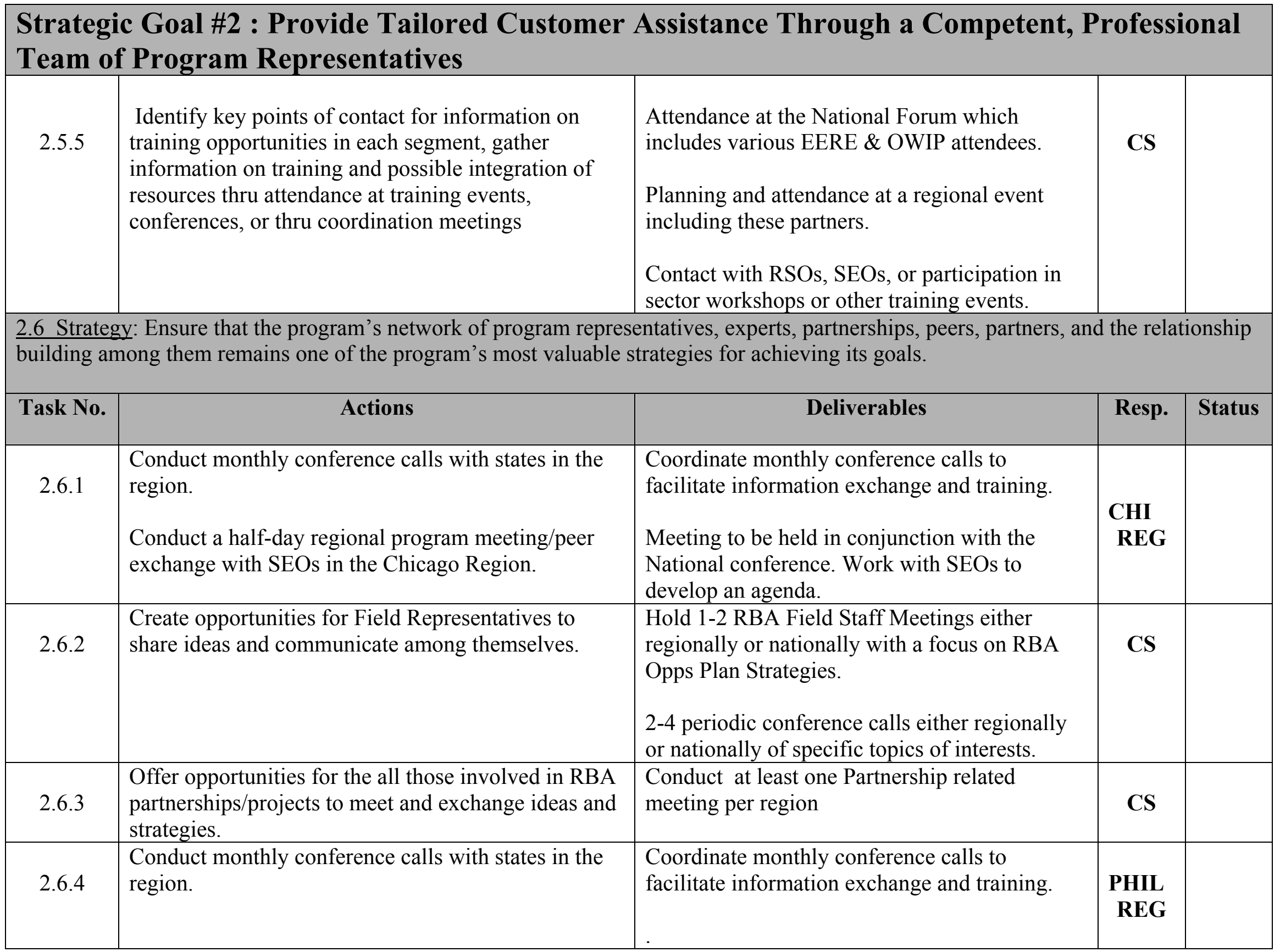




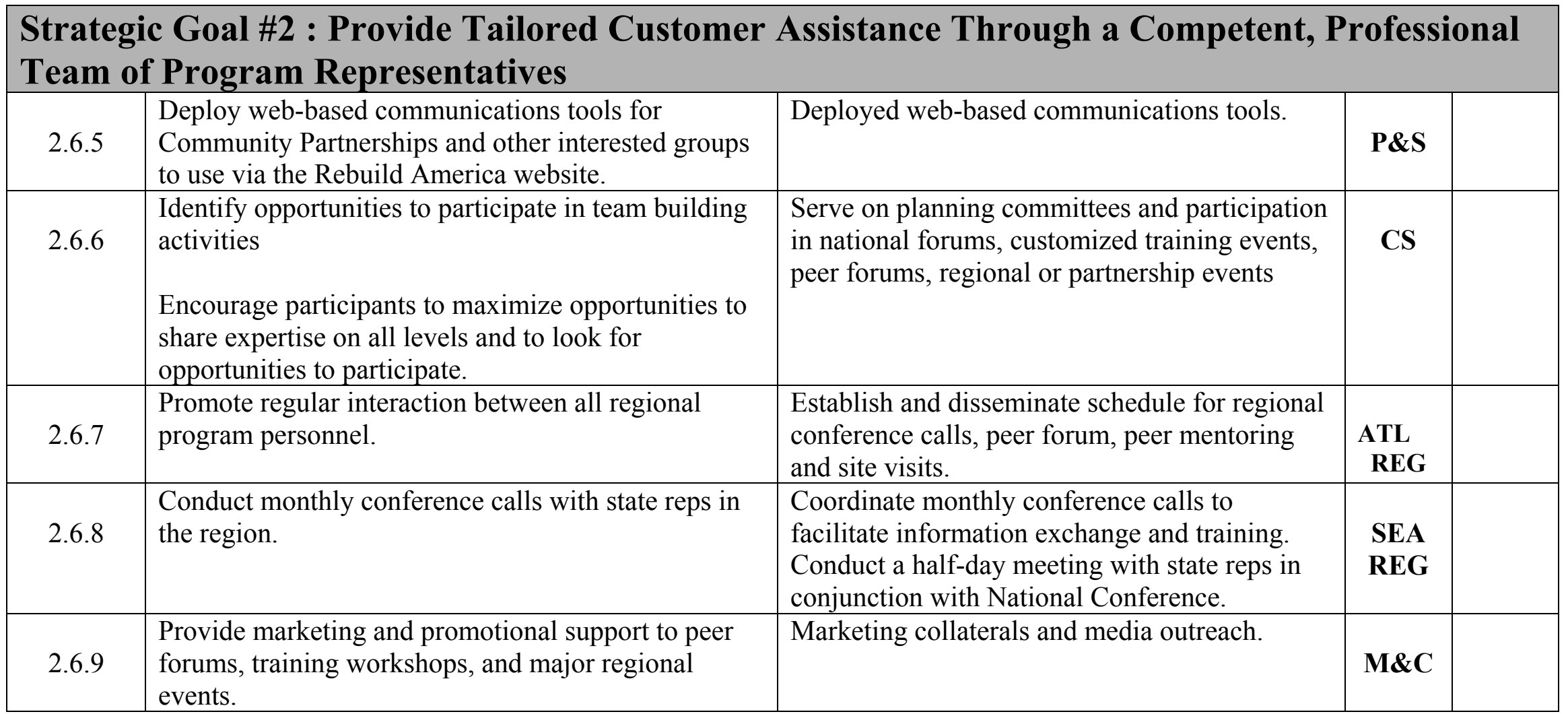




\section{Strategic Goal \#3 : Increase Awareness and Use of Technical Assistance Tools and Resources}

3.1 Strategy: Assemble and regularly update a core set of assistance resources and services that are most commonly requested and needed by partnerships. Sources include materials available from DOE and its national laboratories, the Energy Star program, Strategic and Business partners, and other federal, state, and local agencies.

\begin{tabular}{|c|c|c|c|c|}
\hline Task No. & Actions & Deliverables & Resp. & Status \\
\hline 3.1 .2 & $\begin{array}{l}\text { If team concept is determined to be a cost-effective } \\
\text { delivery mechanism, Determine } 3-5 \text { areas of assistance } \\
\text { for which packages of resources and services would be } \\
\text { developed, develop and beta test packages. } \\
\text { Coordinate teams of existing Rebuild personnel to } \\
\text { address } 3-5 \text { areas of assistances. }\end{array}$ & $\begin{array}{l}\text { Deliver packages to fulfill TBD TA requests. } \\
\text { Teams that are ready to provide customized } \\
\text { assistance to TBD requests. }\end{array}$ & $\mathbf{P \& S}$ & \\
\hline 3.1 .3 & $\begin{array}{l}\text { Review } 2003 \text { Web Trends for Solution Center- } \\
\text { determine common requests. Liaison with CS for Most } \\
\text { Needed List. Perform Gap Analysis. } \\
\text { Promote via HTML email to CP's }\end{array}$ & Promote via HTML email to CP's & P\&S & \\
\hline 3.1 .5 & $\begin{array}{l}\text { Create a mechanism, within the program website, to } \\
\text { allow easy access to the network of experts for } \\
\text { partnerships and the general public. }\end{array}$ & $\begin{array}{l}\text { New content design and functionality for the } \\
\text { program website. }\end{array}$ & P\&S & \\
\hline
\end{tabular}




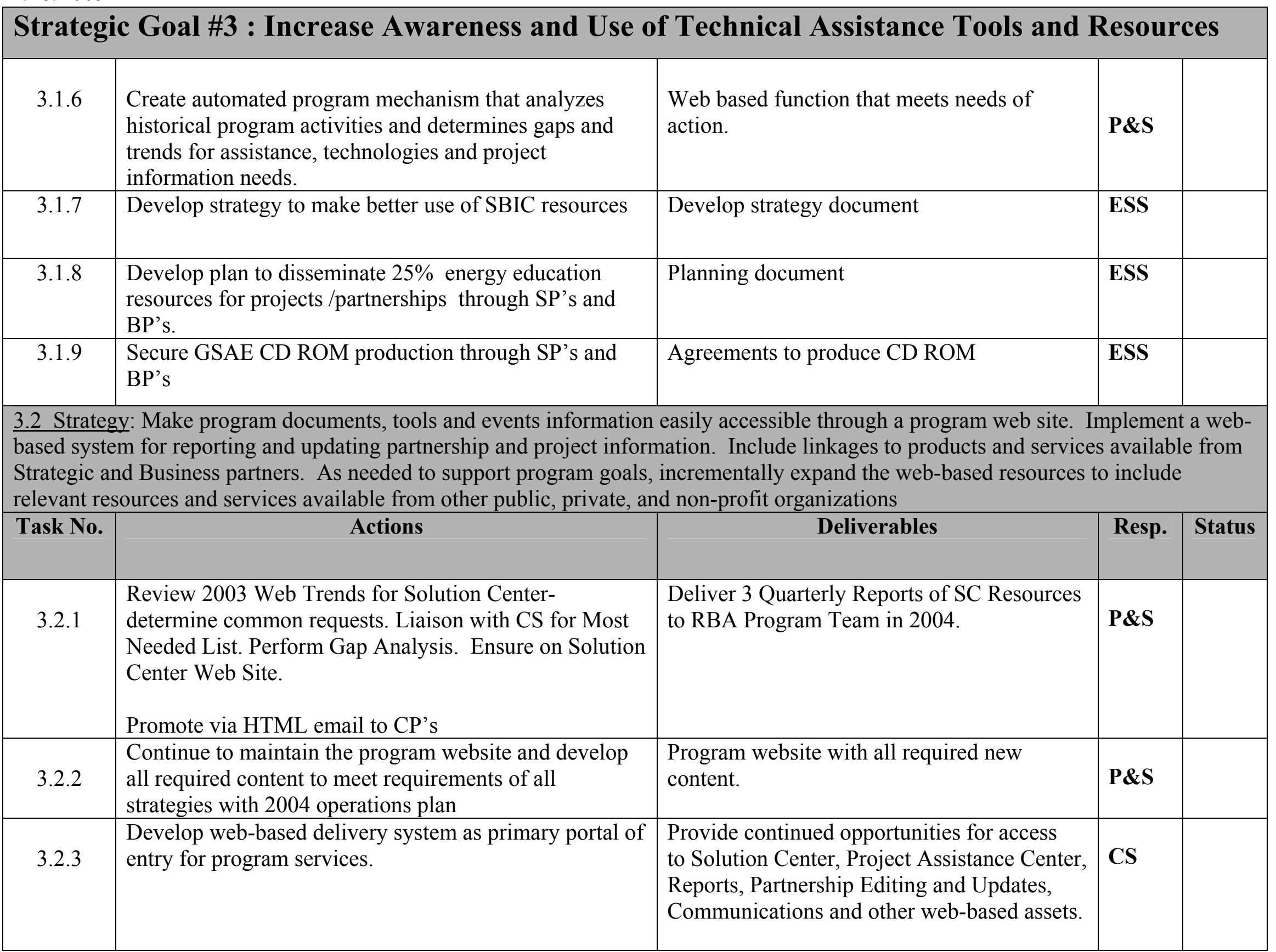




\section{Strategic Goal \#3 : Increase Awareness and Use of Technical Assistance Tools and Resources}

\begin{tabular}{|c|c|c|c|c|}
\hline 3.2 .4 & $\begin{array}{l}\text { Encourage States, Regional Offices, Strategic \& } \\
\text { Business Partners to utilize web by providing additional } \\
\text { training opportunities, direct access to secure network, } \\
\text { and target marketing. }\end{array}$ & $\begin{array}{l}\text { Provide opportunities for training and access } \\
\text { to web, or web team members by Web Ex, } \\
\text { demonstrations on CD Rom, at conferences } \\
\text { or training events, and in the field by Reps. }\end{array}$ & CS & \\
\hline 3.2 .5 & $\begin{array}{l}\text { Provide linkages to additional resources provided by } \\
\text { public, private, and non-profit organizations. }\end{array}$ & Website links to appropriate resources & CS & \\
\hline 3.2 .6 & $\begin{array}{l}\text { Update and maintain Web-based marketing and } \\
\text { communications tools, resources, and materials }\end{array}$ & $\begin{array}{l}\text { Bi-weekly updates to home page and related } \\
\text { features; additions to Press Room; fresh } \\
\text { content for program description pages; html } \\
\text { template and bi-monthly online editions of } \\
\text { Update newsletter }\end{array}$ & M\&C & \\
\hline 3.2 .7 & $\begin{array}{l}\text { Update partnership and project Web profiles with } \\
\text { materials developed for success stories, Flash Reports, } \\
\text { newsletter and other marketing communications } \\
\text { initiatives }\end{array}$ & $\begin{array}{l}\text { Expanded records of partnership and project } \\
\text { milestones and key developments }\end{array}$ & M\&C & \\
\hline 3.2 .8 & Identify opportunities available to partnerships & $\begin{array}{l}\text { Continue to provide information on Rebuild } \\
\text { America's website which is an effective and } \\
\text { useful tool for data collection and } \\
\text { dissemination of information and resource } \\
\text { and data collection. Provide information to } \\
\text { program reps and partnerships for specialty } \\
\text { types of assistance from the solutions center. }\end{array}$ & $\begin{array}{l}\text { SEA } \\
\text { REG }\end{array}$ & \\
\hline \multicolumn{5}{|c|}{$\begin{array}{l}\text { 3.3 Strategy: Continually improve access to and quality of reference and technical assistance services available to partnerships from } \\
\text { EREC. }\end{array}$} \\
\hline Task No. & Actions & Deliverables & Resp. & Status \\
\hline 3.3.1 & $\begin{array}{l}\text { Conduct review of provided assistance from } 2002 \& \\
2003 \text { to determine areas of opportunity for additional } \\
\text { services and opportunities for process improvement }\end{array}$ & $\begin{array}{l}\text { Report of recommendations to RBA } \\
\text { Management }\end{array}$ & P\&S & \\
\hline
\end{tabular}




\section{Strategic Goal \#3 : Increase Awareness and Use of Technical Assistance Tools and Resources}

\begin{tabular}{|c|l|l|l|l|}
\hline 3.3 .2 & $\begin{array}{l}\text { Evaluate most commonly requested marketing } \\
\text { communications TA and create Web-based resources for } \\
\text { partnerships to access and use directly }\end{array}$ & $\begin{array}{l}\text { On-line templates, modules and "how to" } \\
\text { guidance }\end{array}$ & M\&C \\
\hline
\end{tabular}

3.4 Strategy: For all workshops and assistance services, define and consistently apply an entry and follow up strategy. The strategy will set forth expectations for assistance services, requirements for providing them, and follow-up activities. Similarly, it will define responsibilities and guidelines for service providers.

\begin{tabular}{|c|c|c|c|c|}
\hline Task No. & Actions & Deliverables & Resp. & Status \\
\hline 3.4 .1 & $\begin{array}{l}\text { Review existing entry/follow-up responsibilities of } \\
\text { program team members and adjust as needed to align } \\
\text { with current program needs }\end{array}$ & $\begin{array}{l}\text { Program team member roles \& } \\
\text { responsibilities }\end{array}$ & P\&S & \\
\hline 3.4 .2 & $\begin{array}{l}\text { Disseminate roles \& responsibilities to all cognizant } \\
\text { team members to ensure all are aware of their } \\
\text { importance }\end{array}$ & Communications protocol & P\&S & \\
\hline 3.4 .3 & $\begin{array}{l}\text { Create evaluation process to measure effectiveness of } \\
\text { entry/follow-up strategy, tie to staff evaluations if } \\
\text { necessary to ensure implementation }\end{array}$ & Evaluation process & P\&S & \\
\hline 3.4 .4 & $\begin{array}{l}\text { Use of the PAC Technology Seminar Request process- } \\
\text { review and compile results for BP }\end{array}$ & Report to Management Team about metrics & $\mathbf{P} \& \mathbf{S}$ & \\
\hline 3.4 .5 & $\begin{array}{l}\text { Continue to use Project Assistance Center for requesting } \\
\text { and processing of all assistance, seminar, and training } \\
\text { requests. }\end{array}$ & Project Assistance Center. & P\&S & \\
\hline 3.4 .6 & $\begin{array}{l}\text { Create "self-service" templates for workshop and event } \\
\text { promotion and publicity }\end{array}$ & $\begin{array}{l}\text { HTML and print templates; event postings } \\
\text { for data base and Flash Report }\end{array}$ & $\mathbf{M} \& \mathbf{C}$ & \\
\hline \multicolumn{5}{|c|}{$\begin{array}{l}\text { 3.5 Strategy: Ensure that Strategic Partners and Business Partners have increasing responsibilities for the delivery of assistance } \\
\text { services. Incorporate these services into the regional implementation and marketing plans. }\end{array}$} \\
\hline Task No. & Actions & Deliverables & Resp. & Status \\
\hline
\end{tabular}




\begin{tabular}{|c|c|c|c|c|}
\hline \multicolumn{5}{|c|}{ Strategic Goal \#3 : Increase Awareness and Use of Technical Assistance Tools and Resources } \\
\hline 3.5 .2 & $\begin{array}{l}\text { Identify opportunities to utilize strategic and business } \\
\text { partners. }\end{array}$ & $\begin{array}{l}\text { Incorporate strategic and business partners } \\
\text { into the activities with the MHEC, a compact } \\
\text { organization of } 900 \text { colleges and universities } \\
\text { in } 10 \text { Midwestern states. } \\
\text { Encourage and train SEOs to include } \\
\text { strategic and business partners in their } \\
\text { activities and to utilize their resource in } \\
\text { implementing their projects. } \\
\text { Assist with the completion of at least three } \\
\text { "tech-seminars" in the region. }\end{array}$ & $\begin{array}{l}\text { CHI } \\
\text { REG }\end{array}$ & \\
\hline 3.5 .4 & $\begin{array}{l}\text { Identify and support technical assistance opportunities } \\
\text { for business partner participation }\end{array}$ & $\begin{array}{l}\text { Conduct at least } 4 \text { technical information } \\
\text { workshops in the region including Tech } 101 \\
\text { Seminars and High Performance Schools } \\
\text { Workshops. }\end{array}$ & $\begin{array}{l}\text { ATL } \\
\text { REG }\end{array}$ & \\
\hline 3.5 .5 & Solicit strategic/business partner assistance services & $\begin{array}{l}\text { Technical support and workshops by } \\
\text { strategic/business partners. }\end{array}$ & $\begin{array}{l}\text { DEN } \\
\text { REG }\end{array}$ & \\
\hline
\end{tabular}




\section{Strategic Goal \#3 : Increase Awareness and Use of Technical Assistance Tools and Resources}

3.6 Strategy: Integrate the Energy Star platform and its tools and services into the Rebuild America products and services portfolio.

\begin{tabular}{|c|l|l|l|}
\hline Task No. & \multicolumn{1}{|c|}{ Actions } & Deliverables & \multicolumn{1}{|c|}{ Resp. } \\
\hline 3.6 .1 & Facilitate linkages with the ENERGY STAR program. & $\begin{array}{l}\text { Work with SEOs to help them develop } \\
\text { approaches for integrating the programs and } \\
\text { leveraging respective partnerships, networks, } \\
\text { and other resources. Excellent opportunity } \\
\text { here with ENERGY STAR utility, } \\
\text { manufacturers, and retailer partners and with } \\
\text { national campaigns. } \\
\text { REG }\end{array}$ \\
\hline 3.6 .2 & $\begin{array}{l}\text { Review existing SC E* resources, and compare with E* } \\
\text { inventory. Work with DOE/EPA E* to see what should } \\
\text { be added }\end{array}$ & $\begin{array}{l}\text { Work with EPA Region 5 and 7 to provide } \\
\text { building benchmarking and procurement } \\
\text { training for RBA partnerships. }\end{array}$ \\
\hline $\begin{array}{l}\text { Implementation strategy to increase E* } \\
\text { content on RBA website and within program }\end{array}$ & P\&S \\
\hline
\end{tabular}




\section{Strategic Goal \#4 : Leverage Private and Non-Traditional Sources of Capital for Building Improvements}

4.1 Strategy: Develop resources and services to guide partnerships in accessing State Public Benefits Funds in support of energy efficiency improvement projects.

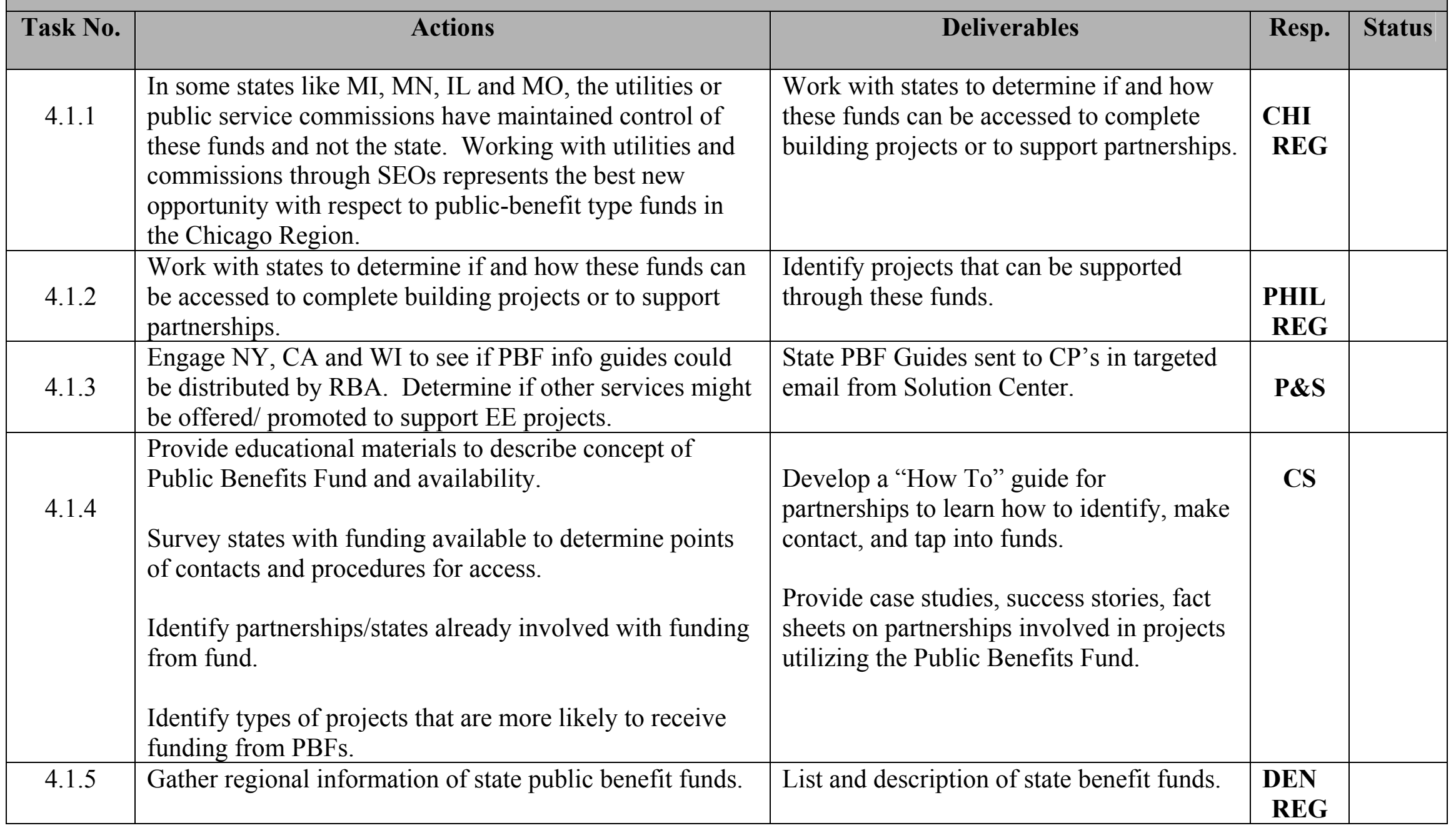




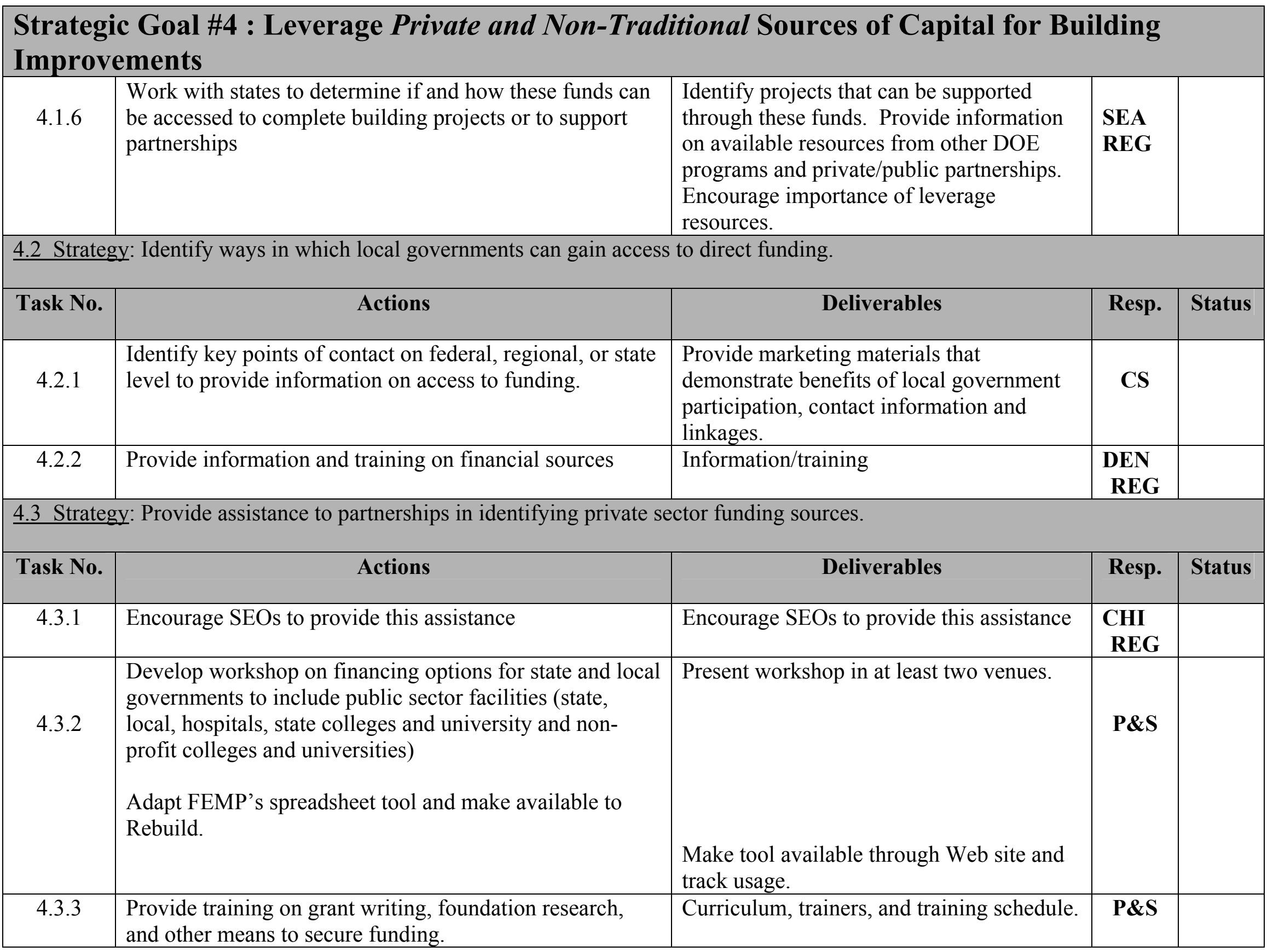




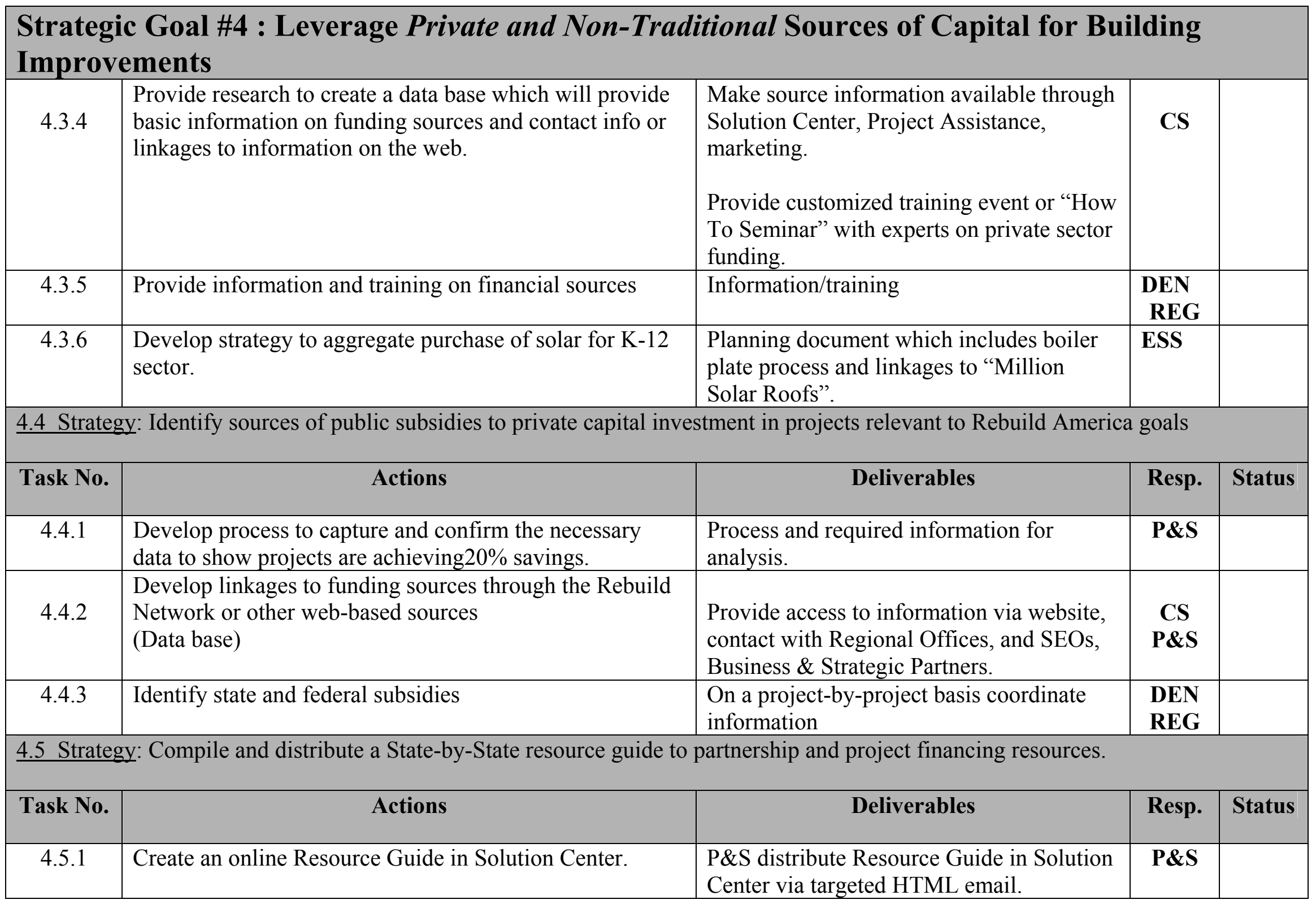




\begin{tabular}{|c|l|l|l|}
\hline $\begin{array}{l}\text { Strategic Goal \#4 : Leverage Private and Non-Traditional Sources of Capital for Building } \\
\text { Improvements }\end{array}$ & $\begin{array}{l}\text { Determine criteria for development of guide, suspense } \\
\text { dates for delivery of key elements, methods of distribution } \\
\text { and resource identification. }\end{array}$ & $\begin{array}{l}\text { Develop access to website or linkages thru } \\
\text { web-based delivery. } \\
\text { Provide period updates. } \\
\text { Disseminate to SEOs, Regional Offices, } \\
\text { Rebuild Network. }\end{array}$ & CS \\
\hline 4.5 .3 & Work with HQ resource on developing this guide & Resource guide & $\begin{array}{l}\text { DEN } \\
\text { REG }\end{array}$ \\
\hline
\end{tabular}




\section{Strategic Goal \#5 : Accelerate the Adoption of Emerging Energy Efficiency and Renewable Energy Technologies and Practices \\ 5.1 Strategy: Develop criteria that facilitate the identification of emerging technologies for inclusion in the list of emerging technologies for promotion.}

\begin{tabular}{|c|c|c|c|c|}
\hline Task No. & Actions & Deliverables & Resp. & Status \\
\hline 5.1 .1 & $\begin{array}{l}\text { Based on criteria used for commercialization for } \\
\text { application of emerging technologies, develop criteria for } \\
\text { Rebuild. }\end{array}$ & $\begin{array}{l}\text { Criteria for application of emerging } \\
\text { technologies, and apply criteria and identify } \\
\text { list of emerging technologies for Rebuild to } \\
\text { work with. }\end{array}$ & P\&S & \\
\hline 5.1 .2 & $\begin{array}{l}\text { Contact sources within DOE, EERE, Labs, and Regional } \\
\text { Offices, along with Business \& Strategic Partners to } \\
\text { assist in identifying and developing criteria. }\end{array}$ & $\begin{array}{l}\text { Provide more detailed information on } \\
\text { technologies by providing contact list, fact } \\
\text { sheets, best practices, success stories, etc. }\end{array}$ & CS & \\
\hline 5.1 .3 & $\begin{array}{l}\text { Provide instruction to state and program reps on } \\
\text { incorporating existing, commercially available renewable } \\
\text { energy technologies into technical assistance } \\
\text { recommendations }\end{array}$ & $\begin{array}{l}\text { Convene workshop for reps and partnerships } \\
\text { on use of hydrogen for stationary energy } \\
\text { generation systems. } \\
\text { Support Fuel Cell demonstration and } \\
\text { education project - Sarasota, Florida }\end{array}$ & $\begin{array}{l}\text { ATL } \\
\text { REG }\end{array}$ & \\
\hline
\end{tabular}

5.2 Strategy: Identify the most appropriate markets for promoting the selected technologies.

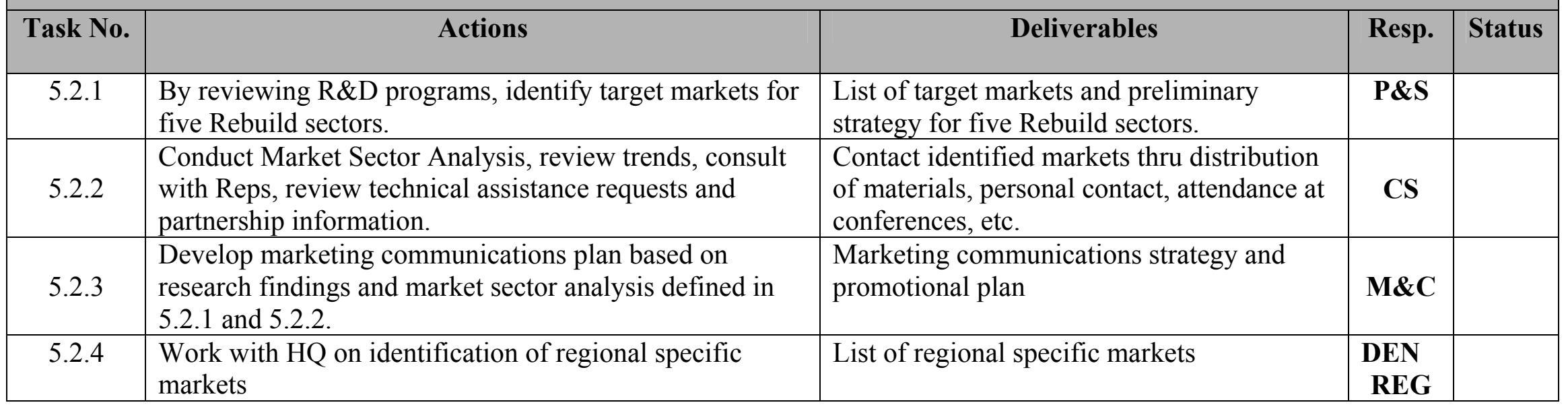




\section{Strategic Goal \#5 : Accelerate the Adoption of Emerging Energy Efficiency and Renewable Energy Technologies and Practices \\ 5.3 Strategy: Identify and support customer service and technical capabilities for promoting the selected technologies.}

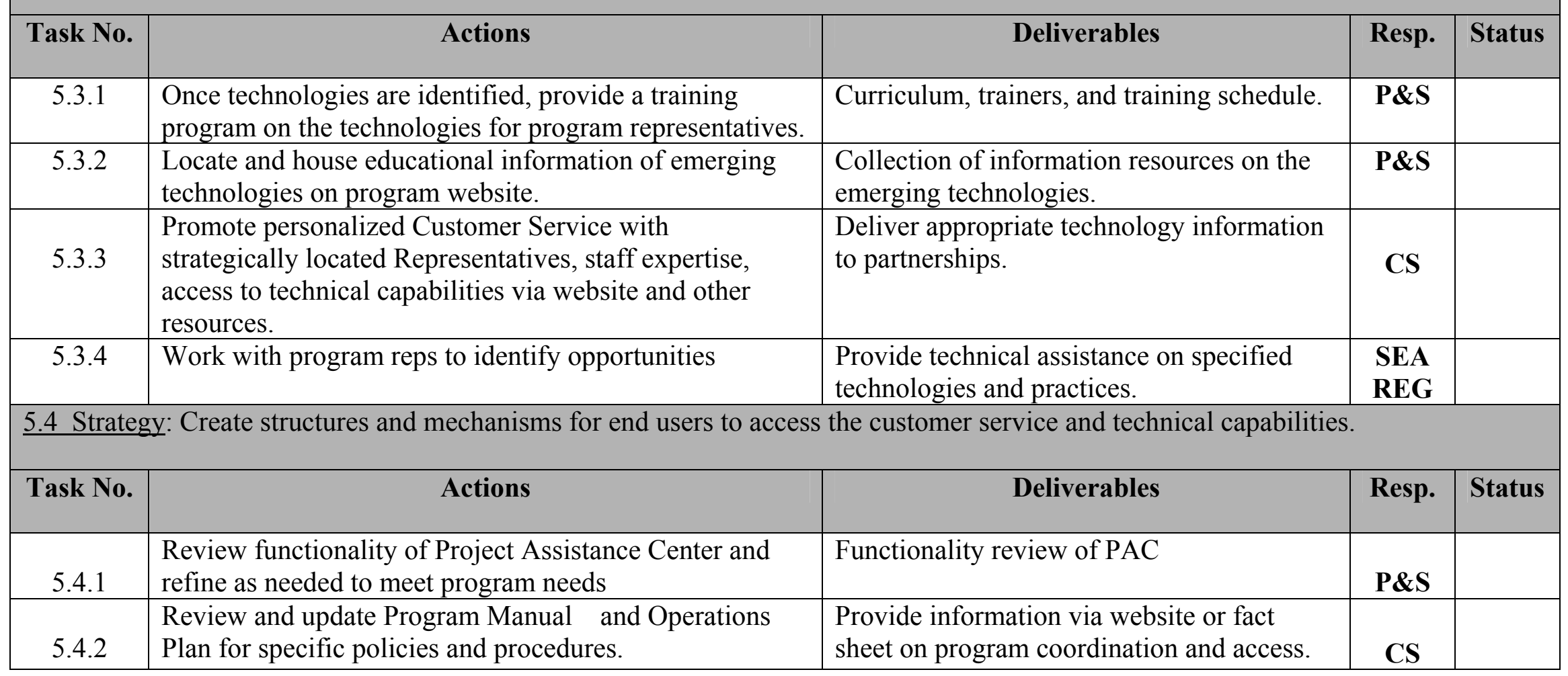




\section{Strategic Goal \#6 : Increase Consumer Demand for Energy Efficiency Through Education, Outreach and Decision-Based Information}

6.1 Strategy: Develop effective ways to showcase results from collected data to stakeholder groups including DOE management, States, partners, and partnerships

\begin{tabular}{|c|c|c|c|c|}
\hline Task No. & Actions & Deliverables & Resp. & Status \\
\hline 6.1 .1 & $\begin{array}{l}\text { Review accuracy of data collected. } \\
\text { Identify trends or key issues which may influence } \\
\text { stakeholder groups. } \\
\text { Determine best way to "package" information for } \\
\text { presentations. } \\
\text { Identify timelines \& opportunities to present. }\end{array}$ & $\begin{array}{l}\text { Gather feedback from the field about results } \\
\text { and impact. } \\
\text { Review with management team and } \\
\text { Regional Team Leads }\end{array}$ & CS & \\
\hline 6.1 .2 & $\begin{array}{l}\text { Create outreach resources (online and print) that } \\
\text { showcase program results and demonstrate market sector } \\
\text { diversity, project innovation, technology adoption, and } \\
\text { public benefits. Adapt for national and regional } \\
\text { stakeholder interests. }\end{array}$ & $\begin{array}{l}\text { Annual Program Report, success stories, } \\
\text { presentation modules, exhibits and } \\
\text { collaterals, fact sheets, bi-monthly } \\
\text { newsletter. }\end{array}$ & M\&C & \\
\hline \multicolumn{5}{|c|}{$\begin{array}{l}\text { 6.2 Strategy: Conduct comprehensive media outreach through appropriate channels that are coordinated with the program } \\
\text { implementation and marketing plans. Showcase successful partnerships as models for replication by others. Develop standard } \\
\text { presentations targeted to local community leadership groups. }\end{array}$} \\
\hline Task No. & Actions & Deliverables & Resp. & Status \\
\hline 6.2 .1 & $\begin{array}{l}\text { Customer Service reps work with states to identify } \\
\text { success stories. }\end{array}$ & Complete at least four success stories. & $\begin{array}{l}\text { CHI } \\
\text { REG }\end{array}$ & \\
\hline
\end{tabular}




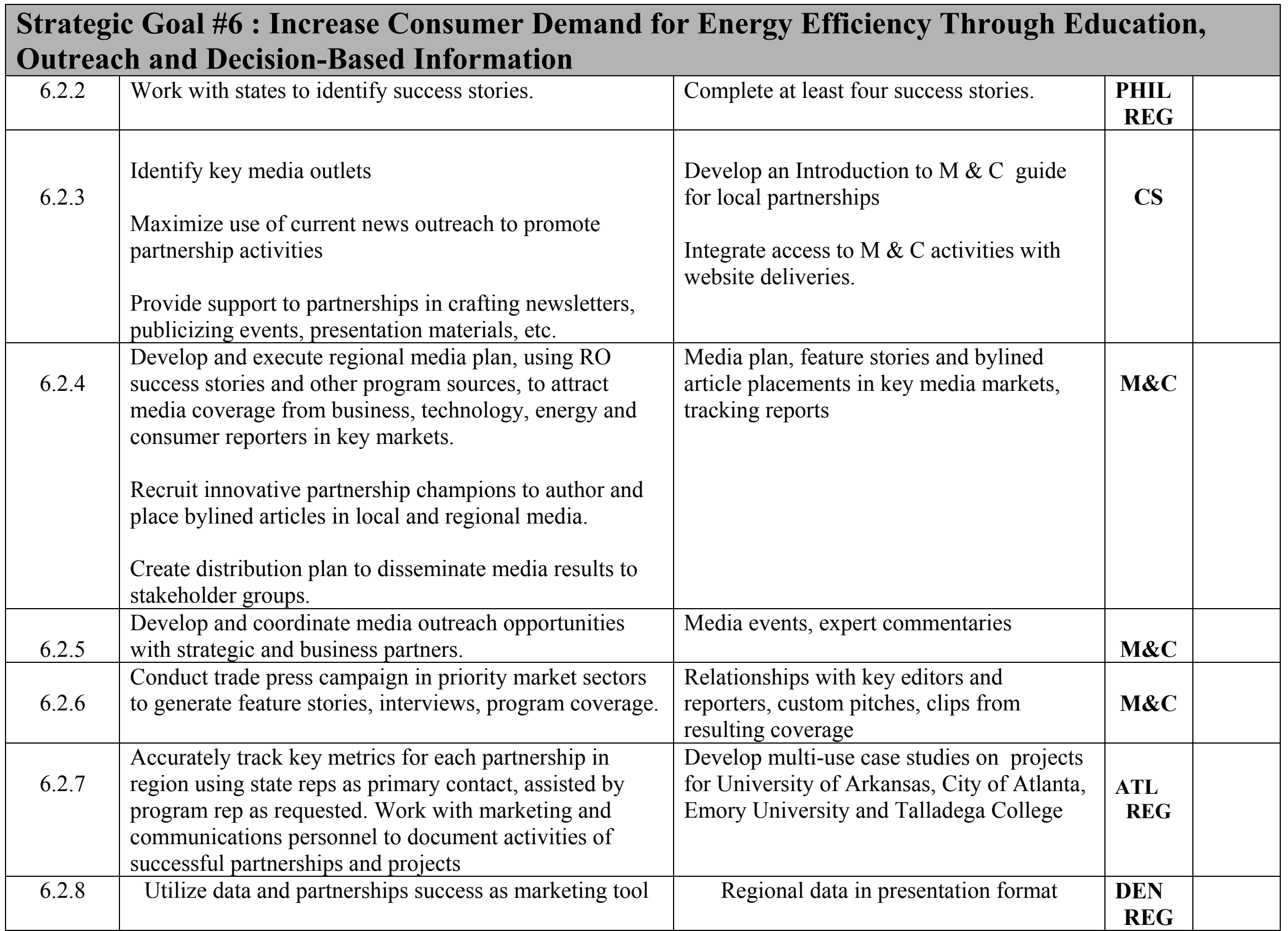




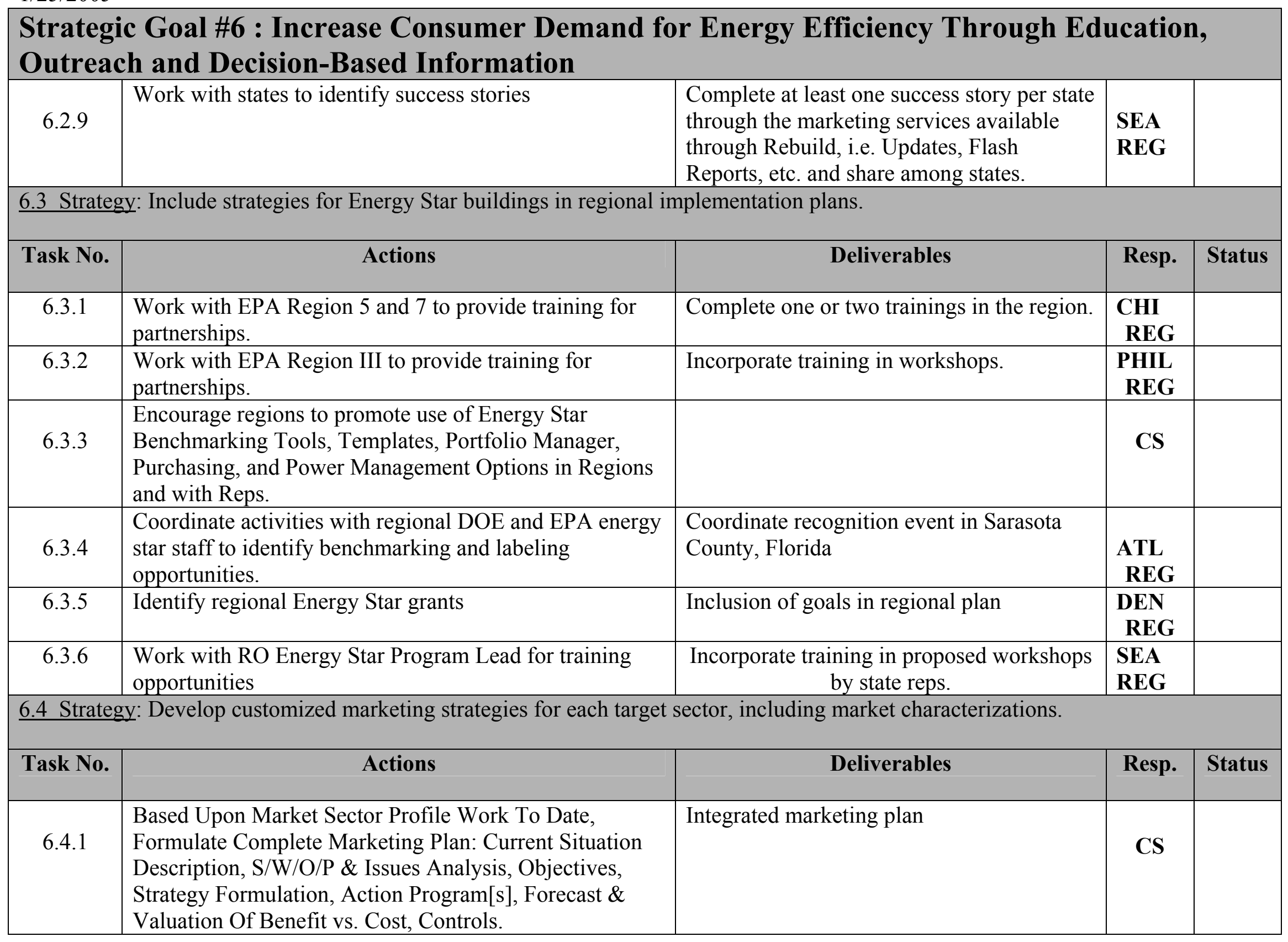




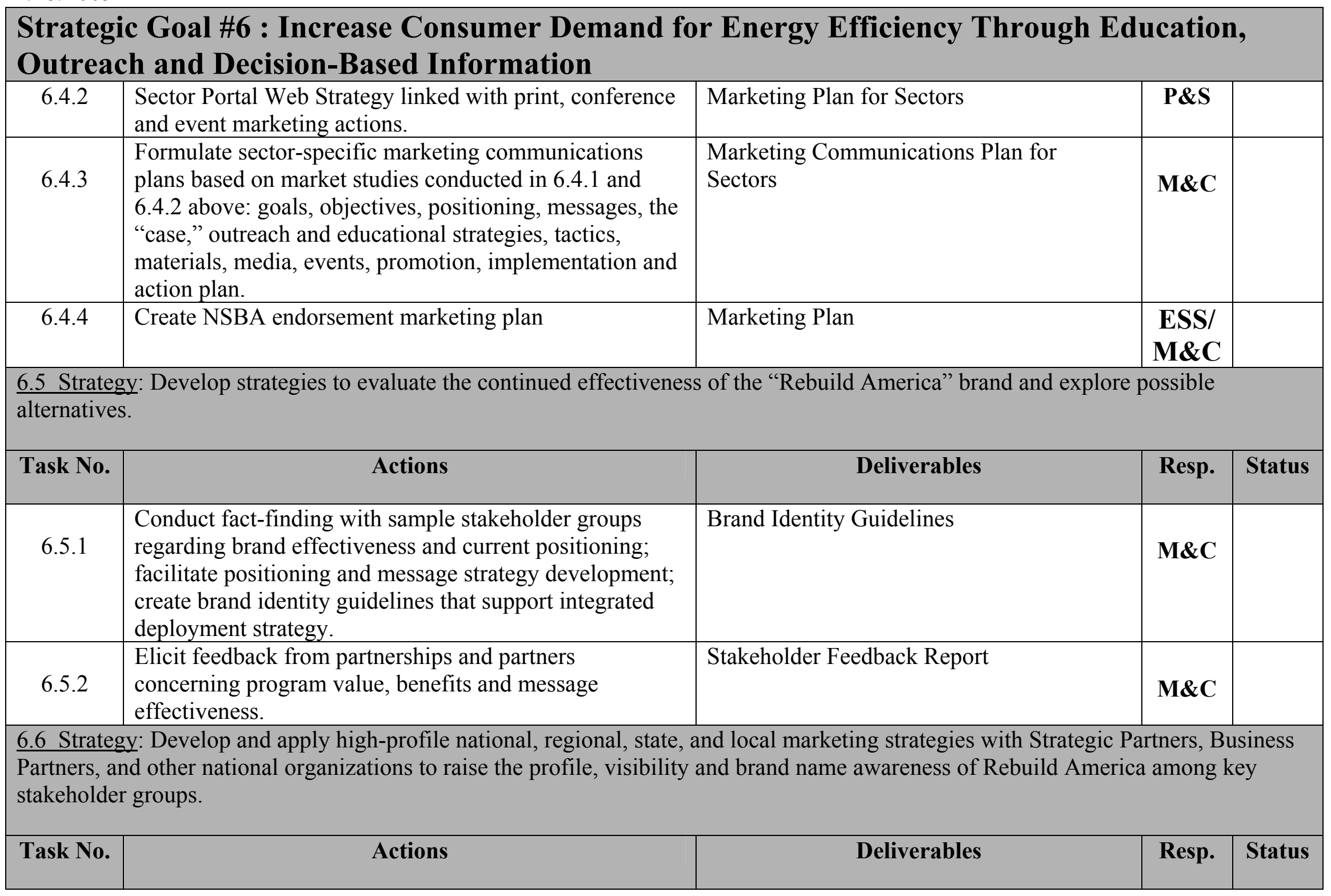




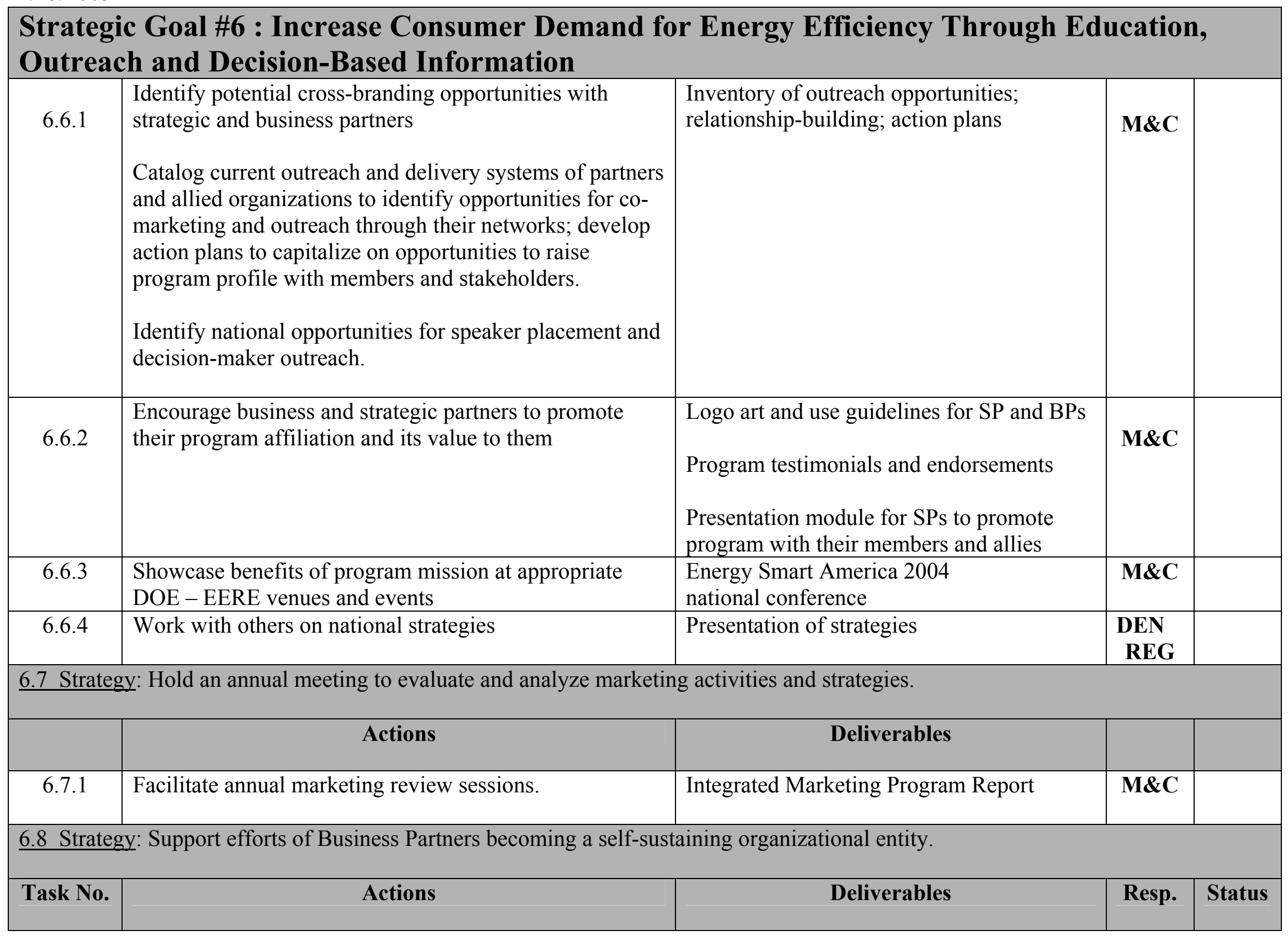




\begin{tabular}{|c|c|c|c|c|}
\hline $\begin{array}{l}\text { Strateg } \\
\text { Outrea }\end{array}$ & $\begin{array}{l}\text { Goal \#6 : Increase Consumer Demand } \\
\text { and Decision-Based Information }\end{array}$ & Energy Efficiency Through & cat & \\
\hline 6.8 .1 & $\begin{array}{l}\text { Solicit interest from Premier Business Partners on the } \\
\text { concept of creating a self-sustaining organizational } \\
\text { entity. }\end{array}$ & Report on BP feedback & $\mathbf{P \& S}$ & \\
\hline 6.8 .2 & $\begin{array}{l}\text { If sufficient interest exists, develop organizational model } \\
\text { for new entity that incorporates tasks } 6.8 .3-6.8 .6 \text {, } \\
\text { including transition strategy, funding requirements, and } \\
\text { management model }\end{array}$ & Transition plan and entity operating model & P\&S & \\
\hline 6.8 .3 & $\begin{array}{l}\text { Fulfill commitments to business partners concerning } \\
\text { promotion and publicity under current organizational } \\
\text { structure and new BP systems } \\
\text { Support expansion of BP network, recruitment, retention }\end{array}$ & $\begin{array}{l}\text { Marketing collaterals (logo art and } \\
\text { guidelines), feature profiles, outreach } \\
\text { opportunity postings }\end{array}$ & M\&C & \\
\hline p.9 Strate & : Continue using Energy Star Small Business services an & marketing support to provide additional $\mathrm{r}$ & es for & \\
\hline 6.9 .1 & $\begin{array}{l}\text { Work with EPA Region } 5 \text { and } 7 \text { to provide resources to } \\
\text { partnerships }\end{array}$ & Resources provided to partnerships. & $\begin{array}{l}\text { CHI } \\
\text { REG }\end{array}$ & \\
\hline 6.9 .2 & $\begin{array}{l}\text { Establish a regional agreement with Energy Star small } \\
\text { business }\end{array}$ & agreement & $\begin{array}{l}\text { DEN } \\
\text { REG }\end{array}$ & \\
\hline
\end{tabular}




\title{
2004 Rebuild America Operational Plan
}

\author{
Deliverables Matrix
}




\section{Rebuild America Operational Plan Key Deliverables Matrix}

\begin{tabular}{|c|c|c|c|}
\hline Deliverable & No./Freq. & $\begin{array}{l}\text { Str. Plan } \\
\text { Goal }\end{array}$ & $\begin{array}{l}\text { Task No. \& } \\
\text { Responsibility }\end{array}$ \\
\hline $\begin{array}{l}\text { Regional implementation plans (see also goal } 1 \text { deliverables below which could be } \\
\text { components of these plans) }\end{array}$ & 1 per region & 1 & 1.1 Regions, CS \\
\hline Strategic planning meetings with states and CS reps. & 2 per yr & 1 & 1.1.3 CHI REG \\
\hline State profile, SWOT analysis, needs assessment, contractor action plans & $\begin{array}{l}1 \text { per state in } \\
\text { region ( } 50 \text { total?) }\end{array}$ & 1 & $\begin{array}{l}\text { 1.1.3 All } \\
\text { Regions? }\end{array}$ \\
\hline Omnibus cooperative agreements with states & $4-6$ & 1 & $\begin{array}{l}\text { 1.1.4 CHI REG } \\
\text { 1.1.7 PHI REG }\end{array}$ \\
\hline Consolidate regional plans into one document & 1 & 1 & $1.1 .5 \mathrm{CS}$ \\
\hline $\begin{array}{l}\text { Develop background metrics data by region by sector from May } 2001 \text { to December } \\
2003\end{array}$ & 1 & 1 & $\begin{array}{l}\text { 1.1.6 Already } \\
\text { done by Aspen }\end{array}$ \\
\hline Regional rep training workshop & 1 (per region) & 1 & $\begin{array}{l}\text { 1.1.10 All } \\
\text { Regions? }\end{array}$ \\
\hline Action plan for working with NASEO Buildings Committee & 1 & 1 & $1.2 .2 \mathrm{CS}$ \\
\hline Develop annual market sector targets (based on Goal 6 strategic marketing plan) & 1 set of targets & 1 & $1.3 \mathrm{P} \& \mathrm{~S}$ \\
\hline Develop sector briefs and related materials & 1 set per sector & 1 & 1.3.2 M\&C \\
\hline Collect appropriate metrics and report progress (see detailed reports below) & See below & 1 & \\
\hline Program metrics executive summary & 1 per quarter & 1 & 1.4.2 CS \\
\hline Annual Program Report & 1 & 1 & $1.4 .3 \mathrm{CS}$ \\
\hline Energy Education metrics & 1 & 1 & 1.4.13 ESS/P\&S \\
\hline Web case study for high-performance buildings & 1 & 1 & 1.5.2 P\&S \\
\hline "Packaged TA planning service" for high-performance buildings & 1 & 1 & 1.5.2 P\&S \\
\hline HP Schools Design Guidelines and LEED rating & 1 & 1 & 1.5.5 ESS \\
\hline Customized materials on working with partnerships or within certain market sectors & TBD & 2 & $2.1 .1 \mathrm{CS}$ \\
\hline Develop packets for each of the market sectors to include promotional materials & 1 per sector? & 2 & $2.1 .2 \mathrm{CS}$ \\
\hline Technology fact sheet series & 1 per technology? & 2 & $2.1 .5 \mathrm{M} \& \mathrm{C}$ \\
\hline $\begin{array}{l}\text { Process document on evaluating and selecting SP or BP staff to serve as program reps. } \\
\text { for partnerships }\end{array}$ & 1 & 2 & 2.2.1 P\&S \\
\hline Report and recommendations on measures of customer service effectiveness & 1 & 2 & $2.3 .1 \mathrm{CS}$ \\
\hline TA request report & Monthly -12 & 2 & 2.3.2 P\&S \\
\hline TA request assessment & 1 & 2 & $2.3 .3 \mathrm{CS}$ \\
\hline
\end{tabular}




\begin{tabular}{|c|c|c|c|}
\hline Deliverable & No./Freq. & $\begin{array}{l}\text { Str. Plan } \\
\text { Goal }\end{array}$ & $\begin{array}{l}\text { Task No. \& } \\
\text { Responsibility }\end{array}$ \\
\hline Initiate leadership training modules to RBA team (workshops) & $2-4$ per region & 2 & $2.4 .2 \mathrm{CS}$ \\
\hline Develop modules of training & TBD & 2 & 2.4.5 CS \\
\hline Training reps on current and emerging technologies & TBD & 2 & 2.4.4 P\&S \\
\hline Conduct state energy office planning sessions & 3-5 per year & 2 & $2.5 .3 \mathrm{CS}$ \\
\hline RBA field staff meetings & $1-2$ & 2 & $2.6 .2 \mathrm{CS}$ \\
\hline Deploy web-based communications tools for CPs and other interested groups & 1 per quarter & 2 & $2.6 .5 \mathrm{P} \& \mathrm{~S}$ \\
\hline Analysis of team delivery concept & 1 & 3 & 3.1 .1 \\
\hline $\begin{array}{l}\text { Create network of experts and support offering with new content design and } \\
\text { functionality in the website }\end{array}$ & 1 network & 3 & 3.1.4, 3.1.5, P\&S \\
\hline Develop strategy to make better use of SBIC resources & 1 & 3 & 3.1.7 ESS \\
\hline Plan to disseminate $25 \%$ of energy education resources through SP's and BP's. & 1 & 3 & 3.1.8 ESS \\
\hline Secure GSAE CD ROM production through SP's and BP's & 1 & 3 & 3.1.9 ESS \\
\hline Review web trends for Solution Center & $\begin{array}{l}1 \text { report per } \\
\text { quarter }\end{array}$ & 3 & 3.2.1 P\&S \\
\hline Various website enhancements, updating and maintenance & TBD & 3 & 3.2.2, 3.2.3 P\&S \\
\hline EREC - review of existing services & 1 & 3 & 3.3.1 P\&S \\
\hline Use PAC Technology Seminar Request process to develop workshop metrics & TBD & 3 & 3.4.4 P\&S \\
\hline Conduct seminars for 'High Performance Schools". & 25 & 3 & 3.5.6 P\&S/ ESS \\
\hline $\begin{array}{l}\text { Develop a "how to" guide for partnerships on accessing State Public Benefit funds } \\
\text { (note: much of this material may already exist }\end{array}$ & 1 & 4 & $4.1 .4 \mathrm{CS}$ \\
\hline Provide case studies, close-ups, fact sheets on partnerships that utilize SPB funds & TBD & 4 & 4.1.4 CS \\
\hline Develop workshop on financing options for state and local governments & 2 events & 4 & 4.3.2 P\&S \\
\hline Adapt FEMP spreadsheet tool and make available through RBA website & 1 tool & 4 & 4.3.2 P\&S \\
\hline Provide training on grant writing and other means to secure funding & TBD & 4 & 4.3.3 P\&S \\
\hline Create data base of basic information on private funding sources and make available & 1 & 4 & 4.3.4 CS \\
\hline Provide customized training event on private sector funding & 1 & 4 & $4.3 .4 \mathrm{CS}$ \\
\hline Develop strategy to aggregate purchase of solar for K-12 sector. & 1 & 4 & 4.3.6 ESS \\
\hline $\begin{array}{l}\text { Develop linkages to sources of public subsidies to private investment in relevant } \\
\text { projects }\end{array}$ & 1 & 4 & 4.4.2 CS, P\&S \\
\hline $\begin{array}{l}\text { Compile and distribute a state-by-state resource guide (could be distributed online via } \\
\text { Solutions Center }\end{array}$ & 1 & 4 & $4.5 \mathrm{CS}, \mathrm{P} \& \mathrm{~S}$ \\
\hline Develop identification criteria and list of emerging technologies for promotion & 1 set each & 5 & $\begin{array}{l}\text { 5.1.1, 5.1.2 CS, } \\
\text { P\&S }\end{array}$ \\
\hline List of target markets and preliminary strategy for 5 Rebuild sectors & TBD & 5 & $5.2 .1,5.2 .2$ \\
\hline
\end{tabular}




\begin{tabular}{|c|c|c|c|}
\hline Deliverable & No./Freq. & $\begin{array}{l}\text { Str. Plan } \\
\text { Goal }\end{array}$ & $\begin{array}{l}\text { Task No. \& } \\
\text { Responsibility }\end{array}$ \\
\hline & & & $\mathrm{P} \& \mathrm{~S}, \mathrm{CS}$ \\
\hline Collection of information resources on the emerging technologies & 1 info. Base & 5 & 5.3.2 P\&S \\
\hline Partnership success story documents and "presentation modules" & $\begin{array}{l}1 \text { per sector per } \\
\text { region }\end{array}$ & 6 & $\begin{array}{l}6.1 .2,6.2 .1 \\
\mathrm{M} \& \mathrm{C}\end{array}$ \\
\hline Develop an Introduction to M\&C guide for local partnerships & 1 guide & 6 & $6.2 .3 \mathrm{M} \& \mathrm{C}$ \\
\hline Develop and place Op-Ed pieces & 2 per quarter & 6 & \multirow{3}{*}{$\begin{array}{l}6.2 .3-6.2 .6 \\
M \& C\end{array}$} \\
\hline Feature stories in trade publications & 2 stories & 6 & \\
\hline Media monitoring reports & TBD & 6 & \\
\hline Develop customized marketing strategies for each sector & TBD & 6 & $\begin{array}{l}\text { 6.4.1 CS, P\&S, } \\
\mathrm{M} \& \mathrm{C}\end{array}$ \\
\hline Create NSBA endorsement marketing plan & 1 & 6 & $\mathrm{ESS} / \mathrm{M} \& \mathrm{C}$ \\
\hline Rebuild America brand: brand identity guidelines and stakeholder feedback report & 2 reports & 6 & $6.5 \mathrm{M} \& \mathrm{C}$ \\
\hline $\begin{array}{l}\text { Develop marketing strategies with SPs, BPs, and other national organizations to raise } \\
\text { profile of RBA }\end{array}$ & TBD & 6 & $6.6 \mathrm{M} \& \mathrm{C}$ \\
\hline Energy Smart America 2004 national conference & 1 event & 6 & 6.6.3 M\&C \\
\hline Hold annual meeting to evaluate and analyze marketing activities and strategies & $\begin{array}{l}1 \text { event \& } 1 \\
\text { report }\end{array}$ & 6 & $6.7 \mathrm{M} \& \mathrm{C}$ \\
\hline Report on Business Partner feedback to self-sustaining organization concept & 1 report & 6 & $6.8 .1 \mathrm{P} \& \mathrm{~S}$ \\
\hline
\end{tabular}




\section{APPENDIX E}

Regional Rebuild America Marketing and Customer Service Plan for $\mathbf{2 0 0 0}$ 


\title{
Regional Rebuild America Marketing and Customer Service Plan for $\mathbf{2 0 0 0}$
}

\section{For the Western and Pacific Region Served by the Seattle Regional Office}

\author{
Submitted \\ November 1999
}

For additional information, please contact Paul Johnson on 206-553-2154 


\section{Contents}

Executive Summary $\quad 4$

I Background 6

A. Purpose 6

B Overview of the Region 6

C. Rebuild America Activity in the Region 7

II. Assessment of Our Regional Program as It Currently Exists 8

A. Profile of our Current Partnerships 8

B. Program Needs 8

1. Regional Program 8

2. State, Territory and Native American 9

$\begin{array}{ll}\text { III. } & \text { Regional Plan for } 2000\end{array}$

$\begin{array}{ll}\text { A. Vision } & 10\end{array}$

B. Strategic Directions 10

C. Rebuild America Priorities and Objectives 11

1. National Program 11

2. Regional Program 11

3. State, Territory and Native American Programs 12

D. Marketing and Customer Service Activities 13

1. Marketing the Program 15

2. Customer Service 18

3. Documenting, Recognizing, and Sharing our Successes 23

4. Maintaining Communication 26

E. Major Milestones 26

$\begin{array}{ll}\text { F. The Regional Team } & 27\end{array}$

$\begin{array}{ll}\text { 1. Members } & 27\end{array}$

2. Roles and Responsibilities 28

$\begin{array}{ll}\text { G. Regional Metrics } & 30\end{array}$

IV. Future Directions 31 


\section{EXECUTIVE SUMMARY}

This plan briefly describes the evolution of the Rebuild America program in the region served by the Seattle Regional Support Office, assesses the current status of regional program, and identifies what we will do in 2000 to market and serve our Rebuild America partnerships. We designed our approach to address the unique and diverse needs of our region. To achieve this, the plan was developed with input, review and concurrence of our region's Rebuild America program Team consisting of representatives from our support office, contractors, our States and our Territories.

Our region is proud of the accomplishments we have made to significantly expand the scope of our Rebuild Program. However, we want to build on these accomplishments and continue to grow and expand. We need to enhance our region's program in the following manner:

- $\quad$ move more of our existing partnerships to the Action Phase and document results;

- $\quad$ aggressively implement Energy Smart Schools initiative through our program;

- $\quad$ strengthen our work with Native American Nations/organizations in our region;

- $\quad$ add more community-based partners to our partnerships;

- $\quad$ selectively recruit new partnerships into the program; and

- $\quad$ through Peer Exchange, continue to define and strengthen the way we work together as a Regional Team.

We are establishing the following regional metrics for the program.

\begin{tabular}{|c|c|c|c|c|}
\hline Metric & $\begin{array}{c}\text { Actuals } \\
1 / 1 / 99\end{array}$ & $\begin{array}{c}\text { By } \\
\text { 1/1/00 }\end{array}$ & $\begin{array}{c}\text { By } \\
\text { 1/1/01 }\end{array}$ & $\begin{array}{l}\text { Net Goal } \\
\text { for } 2000\end{array}$ \\
\hline \multicolumn{5}{|l|}{ 1. Regional partnerships } \\
\hline A. Total & 61 & 96 & $121^{*}$ & $25^{*}$ \\
\hline B. Developed Action Plans & 37 & 65 & 82 & 17 \\
\hline C. Have Not Developed Action Plans & 24 & 30 & 39 & --- \\
\hline D. In Implementation Phase & 37 & 65 & 80 & 15 \\
\hline E. Addressing Schools & 15 & 33 & 60 & 27 \\
\hline \multirow[t]{2}{*}{ F. Serving As "Gateway" Program } & 8 & 17 & 25 & 8 \\
\hline & $\begin{array}{c}\text { Actuals } \\
1 / 1 / 99\end{array}$ & $\begin{array}{c}\text { By } \\
1 / 1 / 00\end{array}$ & $\begin{array}{c}\text { By } \\
\text { 1/1/01 }\end{array}$ & $\begin{array}{l}\text { Net Goal } \\
\text { for } 2000\end{array}$ \\
\hline Metric & & & & \\
\hline
\end{tabular}




\begin{tabular}{|c|c|c|c|c|}
\hline 2. Success Stories/Close-Ups & $\begin{array}{l}\text { not } \\
\text { determined }\end{array}$ & 20 & 41 & 21 \\
\hline \multicolumn{5}{|l|}{ 3. Partnership Performance } \\
\hline $\begin{array}{l}\text { A. Sq. Feet of Renovations- } \\
\text { Committed }\end{array}$ & $\begin{array}{l}\text { not } \\
\text { determined }\end{array}$ & $\begin{array}{l}48 \\
\text { million }\end{array}$ & $\begin{array}{l}67 \\
\text { million }\end{array}$ & $\begin{array}{l}19 \\
\text { million }\end{array}$ \\
\hline B. Sq. Feet of Renovations- Actual & $\begin{array}{l}\text { not } \\
\text { determined }\end{array}$ & $\begin{array}{l}96 \\
\text { million }\end{array}$ & $\begin{array}{l}135 \\
\text { million }\end{array}$ & $\begin{array}{l}39 \\
\text { million }\end{array}$ \\
\hline C. Investment \$ & $\begin{array}{l}\text { not } \\
\text { determined }\end{array}$ & $\begin{array}{l}103 \\
\text { million }\end{array}$ & $\begin{array}{l}183 \\
\text { million }\end{array}$ & $\begin{array}{l}80 \\
\text { million }\end{array}$ \\
\hline D. Energy Savings (annual - \$) & $\begin{array}{l}\text { not } \\
\text { determined }\end{array}$ & ---- & ----- & $\begin{array}{l}\$ 35 \\
\text { million }\end{array}$ \\
\hline
\end{tabular}

* This anticipates that 33 new partnerships recruited, 8 partnerships will drop out or be incorporated into other partnerships, leaving a net increase of 25 partnerships.

By early 2000 we will have completed a data collection effort with our partnership to verify their performance to date. We will us the results of that effort to verify the success of our efforts to meet the January 1, 2000 performance metrics listed above. 


\section{BACKGROUND}

\section{A. Purpose}

This Regional Rebuild America Marketing and Customer Services Plan (Plan) was developed to: 1) briefly describe the history of the Rebuild America program in the region served by the Seattle Regional Office and assess the current status of regional program; and, 2) identify the strategies that the region will use in 2000 to market and serve our Rebuild America partnerships. It also establishes the context and rationale for this approach, and metrics we commit to achieve in support of the national program goals and objectives. We designed our approach to address the unique and diverse needs of our vast region.

This Plan is an update of our 1999 plan, which was revised to reflect new program developments and accomplishments during 1999. It was written by staff at the Seattle Regional Office with input and involvement from the Seattle Rebuild America Regional Team. Members of the Regional Team are committed to the strategies described in this plan and the overall success of the Rebuild America program in our region. We see this as a living document that will evolve and change as we gain more experience through the Rebuild America program.

\section{B. Overview of the Region}

The Seattle Region is geographically large and rich in its cultural diversity. The region:

- $\quad$ includes over 45 million people in 8 states (Alaska, Arizona, California, Hawaii, Idaho, Nevada, Oregon, and Washington), 2 territories (Guam and American Samoa), a commonwealth (Northern Marianas), a republic (Palau), and numerous Native American nations;

- $\quad$ stretches from the Arctic Circle to the Mexican border out through the Pacific Islands; across 7 time zones and the International Date Line;

- includes a wide array of climates, energy sources and usage patterns and economies;

- has extensive experience with electric utility restructuring;

- has wide scale interest and involvement in green building design and operation and sustainable development;

- has broad interest and concern about global climate change and includes numerous local governments whose officials make commitments and take actions to reduce their communities' contributions to climate change; and 
- $\quad$ has a wide array of experiences and successes operating energy efficiency and renewable energy programs.

\section{Rebuild America Activity in the Region}

Key highlights of our region's Rebuild America experience are described below:

- It was difficult getting wide support for Rebuild America when it started in the mid 1990s. We had a tough time recruiting partnerships in a program that did not offer incentives to offset the cost of retrofit investments. The initial partnerships were the Conference of Mayors, and cities, states, and non-profits selected through early financial assistance solicitations.

- $\quad$ To broaden the level of involvement in the program we implemented three strategies: 1) used existing partners to recruit other partnerships into the program; 2) recruited states to participate in the program as a means of addressing the needs of their communities; and, 3) procured contractors to serve as Program Representatives to recruit and serve partnerships in geographic areas where states were not involved in the program.

- As a result of these initial strategies, Rebuild activity in the region began to increase significantly. We had 4 partnerships in our region in the fall of 1996. 17 by the fall of 1997; 31 by February 1998; and 61 by January 1999.

- As the numbers of partnerships grew it became clear that our Rebuild "family" included members with a broad array of experiences. We initiated a peer exchange program in our region in early 1998 to take advantage of the expertise within our partnerships. This effort has proven to be very successful. Peer Exchange meetings were held in February and November 1998 and June 1999. About 180 people attended these three meetings, mostly Rebuild partners. We are committed to supporting ongoing Rebuild Peer Exchange in our region by: 1) scheduling regional meetings twice a year; 2) sponsoring joint partnership proposals to foundations or other revenue sources; 3 ) reimbursing certain travel costs for partners not funded by DOE to attend peer exchange events; and 4) using web based communication.

- $\quad$ A Regional Team was developed by DOE for administering the Program in mid 1998. A meeting was held in July in Seattle to discuss the program process. Partnerships were identified as the focal point of the program. Program Representatives were identified as key staff responsible for marketing new partnerships and serving the needs of existing partnerships. States were acknowledged as having the lead for Rebuild Activities within their borders. The 
Regional Office was identified as the head of the Regional Team. This Marketing and Customer Service Plan is the direct result of the Regional Team planning work initiated at that meeting.

- During 1999 much of the effort in the region focused on 1) ways to strengthen and support the Regional Team; 2) selectively recruiting partnerships - with a primary emphasis on schools and Native American governments; 3) beginning to define our approach for carrying out Energy Smart Schools through our region's Rebuild America program; and 4) identifying non-DOE resource of interest to our partnerships.

\section{ASSESSMENT OF OUR REGIONAL PROGRAM}

\section{A. Profile of our Current Partnerships}

We have reviewed our partnerships and found that:

- $\quad$ about a third of these partnerships are led by units of local government; $20 \%$ by state governments; $15 \%$ are led by universities; $15 \%$ by non-profits; and $15 \%$ by for profits. Three partnerships are led by Native America organizations;

- $\quad$ approximately half of our partnerships have developed Action Plans;

- $\quad$ about half of our partnerships are addressing state and local buildings and a similar number are focusing on commercial buildings and schools;

- half of our partnerships have not yet decided on a financing mechanism for project implementation.

- $\quad$ many of the partnerships have not formally moved beyond the lead partner to include other organizations in their partnership.

\section{B. Program Needs}

\section{1. $\quad$ Regional Program}

We are proud of the accomplishments we have made to significantly expand the scope of the Rebuild Program in this region. However, we want to build on these accomplishments and continue to grow and expand. We need to enhance our region's program in the following manner:

- $\quad$ move more of our existing partnerships to the Action Phase and document results;

- $\quad$ strengthen our existing partnerships through the addition of more communitybased partners;

- $\quad$ selectively recruit new partnerships into the program. We shall seek partnerships: 
1) led by organizations not adequately represented in our current partnerships, 2) targeting schools and sectors not adequately represented in our current mix ; and 3 ) interested in using Rebuild as a "gateway" program to address broad community interests through energy efficiency measures;

- through Peer Exchange, continue to define and strengthen the way we work together as a Regional Team; and

- Learn more about the needs and opportunities for working with Native American organizations so that we best support and service the needs of Native American led partnerships.

\section{2. $\quad$ State, Territory and Native American Programs}

States, territories, and Native American Nations administering the program in our region have identified the following general needs for their programs. Recruitment needs identified by our states, territories, and Native American Nations are identified in another part of this plan.

\begin{tabular}{|l|ll|}
\hline \multicolumn{1}{|c|}{ State/Entity } & \multicolumn{1}{c|}{ Major Need } \\
\hline Alaska & $\bullet$ & $\begin{array}{l}\text { Increase the level of retrofit implementation in the } \\
\text { state. }\end{array}$ \\
\hline American Samoa & $\bullet$ & $\begin{array}{l}\text { Assistance relevant to the unique culture. Major } \\
\text { needs/interests are small commercial retrofits, } \\
\text { landfill/waste disposal, and adequate fresh water } \\
\text { supplies }\end{array}$ \\
\hline Arizona & $\bullet$ & $\begin{array}{l}\text { Help contacting successful BOMA partners } \\
\text { Help promoting new technologies }\end{array}$ \\
\hline California & $\bullet$ & $\begin{array}{l}\text { Better way to mesh Rebuild planning process with } \\
\text { State's energy planning process. }\end{array}$ \\
\hline Idaho & $\bullet$ & $\begin{array}{l}\text { Identify/provide funding to partnerships. } \\
\text { More technical assistance focused on private } \\
\text { commercial buildings. }\end{array}$ \\
\hline Guam & $\bullet$ & $\begin{array}{l}\text { Assistance relevant to the unique culture. (Need to } \\
\text { address mostly-concrete buildings, high } \\
\text { maintenance costs, short equipment life - due to } \\
\text { weather conditions) }\end{array}$ \\
\hline Identify funding opportunities
\end{tabular}




\begin{tabular}{|c|c|c|}
\hline & • & $\begin{array}{l}\text { Access to pool of engineers for studies/audits of } \\
\text { community and schools facilities. }\end{array}$ \\
\hline $\begin{array}{l}\text { Native American } \\
\text { Nations }\end{array}$ & $\bullet$ & $\begin{array}{l}\text { Establish network to share info and resource info } \\
\text { Seek new/appropriate roles for Intertribal Councils } \\
\text { in program delivery. } \\
\text { Continued support to ongoing efforts by region's } \\
\text { Program Reps for Native American Nations }\end{array}$ \\
\hline Nevada & $\bullet$ & $\begin{array}{l}\text { Information on funding opportunities and options } \\
\text { Technical training for partnership representatives }\end{array}$ \\
\hline Oregon & $\bullet$ & $\begin{array}{l}\text { Increase energy savings of projects relative to } \\
\text { square footage retrofitted. }\end{array}$ \\
\hline Washington & $\bullet$ & $\begin{array}{l}\text { Help establishing corporate sponsorship of a } \\
\text { Washington schools initiative. } \\
\text { Help identifying sources of seed funding for a } \\
\text { revolving fund for resources managers. } \\
\text { Help taking working with Intertribal Council and } \\
\text { Tribes in state. }\end{array}$ \\
\hline
\end{tabular}

\section{Regional Plan for 2000}

\section{A. Vision}

Over the next year we will work together as a flexible and creative multi-disciplinary team. We will seek to respect and capitalize on the unique assets and diversity of our region to assist our communities, partners and partnerships in developing substantive resource efficiency programs. Our programs will provide substantive benefits for our communities, states, territories and Native American Nations, and add measurable value to the national Rebuild America Program.

\section{B. Strategic Directions}

After several years of operation and with a Regional Team in place, we are proposing the following strategic directions to guide our operations in 2000:

- $\quad$ continue to grow the peer exchange program;

- $\quad$ develop and implement model programs for 1) community partnerships, and 2) Energy Smart Schools (K-12) including a curriculum component and 3) Native American organizations in our region;

- $\quad$ institute a process to formally recognize partners who have developed community based partnerships and implemented projects providing real benefits to local communities; and,

- $\quad$ continue to develop and improve the quality and timeliness of our customer 
service.

\section{Rebuild America Priorities and Objectives}

\section{National Program}

At an October 1999 Management Team Meeting the following National Goals for the Program were proposed for Calendar Year 2000.

- 80 new partnerships

- $\quad 40$ addressing k-12

- $\quad 20$ serving as "gateway" programs

- $\quad 350$ million square feet of energy efficient renovations committed

- 200 million square feet of energy efficient renovations completed

- $\quad \$ 259$ Million in investments dollars

- $\quad \$ 114$ million annual energy savings

We are committed to aggressively pursuing and achieving these national goals through substantive contributions from our Regional Program.

\section{2. $\quad$ Regional Program}

We plan to make significant contributions to National program objectives though our Regional Program. We want to demonstrate leadership for our region's Rebuild America Program and are proposing following regional objectives for 2000:

- $\quad$ to supply tools, products, services, support and necessary resources to strengthen our states' abilities to help our regional partnerships and partners to successfully develop and implement energy and resource use action plans under the Rebuild America program;

- to capture performance metrics of our partnerships;

- $\quad$ to develop and implement an approach to carry out Energy Smart Schools activities in our region;

- $\quad$ to strengthen our Rebuild America partnerships by helping them expand beyond the initial lead partner. To succeed and become self sustaining, partnerships need to include local expertise and resources by expanding the base of community organizations committed to their program;

- To provide information and assistance to our Rebuild America partnerships from various sources to help them select the best approach to develop financially selfsustaining Rebuild America projects; and,

- to develop information and resource networks and other means to best serve the significant and unique needs of Native American-led partnerships in our region. 


\section{State, Territorial and Native American Programs}

States, territories, and Native American Nations administering the program in our region have identified the following priorities for their programs for 2000.

\begin{tabular}{|c|c|}
\hline State/Entity & Priorities \\
\hline Alaska & $\begin{array}{l}\text { - } \\
\text { - } \quad \text { Educate/involve the Department of Education in } \\
\text { Rebuild, and get it to join the Rebuild partnership. } \\
\text { Explore/decide on expansion of Rebuild to urban parts of } \\
\text { the state? }\end{array}$ \\
\hline American Samoa & - $\quad$ Recruit Partners and develop Actions Plan \\
\hline Arizona & $\begin{array}{l}\text { - } \\
\text { impleduced focus on audits/more focus on completed } \\
\text { Incorporate energy efficiency into mandated } \$ 374 \\
\text { million school retrofit effort }\end{array}$ \\
\hline California & $\begin{array}{l}\text { Foster and support development of regional energy } \\
\text { offices in the state. } \\
\text { - } \quad \text { Support multifamily projects through new or existing } \\
\text { partnerships. } \\
\text { Support small business projects through new or existing } \\
\text { partnerships. } \\
\text { Support green building projects through new or existing } \\
\text { partnerships. } \\
\text { Provide technical assistance, cost sharing for audits and } \\
\text { loans for building retrofits from existing state programs. } \\
\text { Coordinate and mesh Rebuild efforts with related state } \\
\text { programs- particularly the Bright Schools Partnership } \\
\text { and Energy Partnership programs. }\end{array}$ \\
\hline Guam & $\begin{array}{l}\text { - } \\
\text { - } \\
\text { Hecruit the DOD Education Agency into Rebuild. } \\
\text { Provide technical assistance to help partnerships } \\
\text { implement Action Plans }\end{array}$ \\
\hline . Hawaii & $\begin{array}{l}\text { - Help partnerships without Action Plans develop } \\
\text { successful plans and help partnerships with plans toward } \\
\text { implementation. } \\
\text { Help strengthen existing partnerships and the Rebuild HI } \\
\text { Consortium. }\end{array}$ \\
\hline Idaho & $\begin{array}{l}\text { - Develop and implement a model community-focused } \\
\text { city and county program. }\end{array}$ \\
\hline
\end{tabular}




\begin{tabular}{|c|c|c|}
\hline & & $\begin{array}{l}\text { Continue to utilize Rebuild as an "umbrella" vehicle for } \\
\text { the state's commercial programs. } \\
\text { Continue the schools RCM program } \\
\text { Provide ongoing support for existing partnerships } \\
\text { Continue partnering efforts with utilities including the } \\
\text { Bonneville Power Administration }\end{array}$ \\
\hline $\begin{array}{l}\text { Native American } \\
\text { Nations }\end{array}$ & • & $\begin{array}{l}\text { Target key tribal groups and tell them about the Rebuild } \\
\text { story } \\
\text { Develop and publicize success stories } \\
\text { Selectively recruit new partnerships }\end{array}$ \\
\hline Oregon & 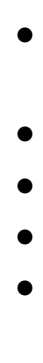 & $\begin{array}{l}\text { Recruit quality new partnerships with multiple } \\
\text { community partners. } \\
\text { Develop Multi-state (OR, WA, ID, MT) RCM effort } \\
\text { Increase level of retrofit investment in Rebuild projects. } \\
\text { Increase participation in OR tax and loan programs. } \\
\text { Help develop and implement aggressive partnership p } \\
\text { action plans. }\end{array}$ \\
\hline Washington & & $\begin{array}{l}\text { Educate key groups, gain their support and create new } \\
\text { partnerships in three key sectors: } \\
\text { - economic/community development; } \\
\text { - schools and universities; } \\
\text { - state agencies } \\
\text { - native American tribes } \\
\text { Help establish an intertribal effort to support Rebuild } \\
\text { related efforts by tribes in the Pacific Northwest. }\end{array}$ \\
\hline
\end{tabular}

\section{Marketing and Customer Service Activities}

Our Approach. The Marketing and Customer Service plan uses the systems thinking philosophy for describing and developing relationships. A systems thinking approach is to look at each partnership and their program elements as an integral part of the whole region's capabilities. It also considers that the sum of these regional elements is greater than the sum of an individual partnership. An important component of the marketing plan will be to look at building a process for model Rebuild communities over the next year. We will document the initial process for developing community partnerships and on-going process changes throughout the year.

To begin, we have learned that no two processes can ever be identical. Each community requires a somewhat unique process for development and implementation of a Rebuild plan. A good plan should seek to fit community needs and add value to existing programs as new opportunities are developed and integrated into the existing community structure.

A community plan begins with the formation of initial partners. One of the first steps of this new partnership is to look for relationships in the community that may already exist or have the 
potential for interaction and positive growth. Criteria need to be built for this search. The plan also includes success stories from partnerships, which are vignettes of successes and challenges that partnerships have faced, including responses and outcomes. Each partnership will eventually develop a set of opportunities. These opportunities are specific program elements that form the wholeness of the partnership. A community's opportunities form the image, or the picture apparent of the community at any moment in time, which changes with time. Our goal is to identify broad opportunities for the region and to assist states and partner communities in their development of opportunities.

The Basic Steps. The following steps will be followed to market and serve Rebuild America partnerships in our region:

- $\quad$ Contacts with prospective partnership leads will be generated from various sources including the National Team, the Regional Team and existing partnerships;

- The Regional Team leader will assign a Program Representative to meet with the lead and determine if the lead is best suited to 1) join an existing partnership, 2) form a new partnership or 3) participate in the program in some other way;

- If a decision is made to form a new partnership, a partnership formation meeting will be held, a partnership application agreement will be signed by the lead/champion, and initial material will be sent to the partnership lead;

- $\quad$ The Program Representative then works with the partnership to 1) identify needs/buildings, 2) help develop and complete an Action Plan, and 3) provide ongoing assistance. The partnership lead takes ownership of the project, expands the scope of the partnership, and seeks assistance through the Program Representative; and

- Ongoing recognition is then provided to the partnership and its partners as milestones are reached.

A detailed description of steps to be followed to market and serve Rebuild America partnerships in our region follows:

\section{Marketing the Program}

a. Guidelines. In 2000 we shall continue to seek: 1) quality not quantity in our partnerships. We want to add partnerships that possess the prerequisites for success; 2) partnerships that will fill a void in our state/territorial/tribal or regional mix; and, 3) partnerships focusing on schools; and 4) partnerships focusing on the and the diverse needs of communities that demonstrate the value of Rebuild as a "gateway" or "umbrella" program for communities.

b. General Marketing Activities. The following methods will be used to market the program:

1) Rebuild America is an excellent means of addressing the diverse needs of 
communities. Many federal programs have a similar community focus and have missions that support and complement the Rebuild America program. (These include Million Solar Roof Initiative, Clean Cities, Energy Star, Motor Challenge, Project Impact, Empowerment Zone Program to name just a few). Most of our States also offer communityoriented programs that complement Rebuild America program. These Federal and state programs can provide additional technical and financial resources to Rebuild America partners. The availability of these programs will be marketed through Rebuild America and others operating programs that complement Rebuild will be asked to market Rebuild America through their programs.

2) Our existing partners are the greatest champions and spokespersons for Rebuild America. The Regional Team will identify opportunities for partners to speak of their Rebuild experiences at conferences or workshops or one-on-one meetings with prospective partners. Prospective partners will be invited to our peer exchange meetings so they can receive direct peer feedback on the benefits of participating in the Rebuild America program.

3) We expect that referrals from 1) Market Sector Managers or others on the National Team 2) other members of the Regional Team; and 3) existing partnerships will be a valuable source of leads for recruiting new or expanding existing Rebuild partnerships. We will follow-up on these leads to determine the most appropriate manner for them to participate in the Rebuild America program.

4) Regional Team members are encouraged to attend regional and national conferences related to the building industry, energy efficiency, climate change, or community development. Such conferences are excellent opportunities to promote Rebuild America and network with industry and community leaders. When appropriate, Regional Team members will present technical or policy papers at these conferences to educate attendees about benefits, limitations, obstacles, and strategies for implementing the Rebuild America program in our region. Individual partners should also be encouraged to share their experiences with their peers by attending these conferences. The Regional Team will also seek opportunities to exhibit Rebuild America promotional material at trade shows, expositions, workshops, conferences, and other special events within our region.

5) Information about the Rebuild America program and activities in our region will be available at both the Rebuild America web site

(http://www.eren.doe.gov/buildings/rebuild) and the Seattle Regional Office web site. The Rebuild America web site contains the new 
Information Management System (IMS) developed by the national team to track partnerships, action plans, and project implementation. The IMS is available to all Rebuild America partners using a password assigned by D\&R International. Lead partners will be responsible for updating information in the IMS, including the status of partnership formation, Action Plan development, building screening and evaluation, project implementation, and verification of energy savings. Partners interested in a particular technology, building type, or financing mechanism can then use the IMS to search for similar projects undertaken by other partnerships, which will help to stimulate new ideas and avoid duplication of effort. The public section of the Rebuild America web site also includes a variety of useful information for current and future partners seeking guidance on energy efficient building retrofits. This section includes program manuals, technical publications, resource listings, points of contact, and links to other building technology web sites.

6) We will use the PowerPoint presentation developed by the National Team as the major tool for explaining Rebuild America to diverse audiences in our region..

7) The Seattle Regional Office will maintain an archive of digital photographs and scanned images of Rebuild America events and projects happening throughout the region. These images will be used to illustrate key themes that we are try to evoke through our region's marketing of the Rebuild America Program. This "image gallery" will eventually be available through either the SRO Web Site or the Rebuild America Information Management System. The images may be used by partners for promotional and educational materials. All Program Representatives are encouraged to submit digital images, Powerpoint Presentations, or video clips to the Regional Team Leader via e-mail or the IMS.

c. Marketing Goals We commit to the following:

\begin{tabular}{|c|c|c|c|}
\hline State/Entity & $\begin{array}{l}\text { Types of New } \\
\text { Partnership Leads to } \\
\text { Be Sought }\end{array}$ & Sectors to be sought & $\begin{array}{l}\# \text { of } \\
\text { Partnerships } \\
\text { to be } \\
\text { Recruited }\end{array}$ \\
\hline Alaska & $\begin{array}{ll}- & \text { University } \\
\text { - } & \text { Other }\end{array}$ & - $\quad$ Schools & 2 \\
\hline $\begin{array}{l}\text { American } \\
\text { Samoa }\end{array}$ & $\begin{array}{ll}\text { - } & \text { Villages } \\
\text { - } & \text { Utility } \\
\text { - } & \text { Government }\end{array}$ & $\begin{array}{l}\text { Industrial and } \\
\text { small/large } \\
\text { commercial }\end{array}$ & 1 \\
\hline
\end{tabular}




\begin{tabular}{|c|c|c|c|}
\hline & - $\quad$ Non-Profits & $\begin{array}{ll}\text { sector } \\
\text { All electric } \\
\text { generators and } \\
\text { end users }\end{array}$ & \\
\hline Arizona & - $\quad$ Cities & $\begin{array}{ll}- & \text { Municipal } \\
\text { - } & \text { Commercial }\end{array}$ & 1 \\
\hline California & $\begin{array}{ll}\text { - } & \text { Municipal } \\
\text { utility districts } \\
\text { and city utility } \\
\text { departments } \\
\text { Regional } \\
\text { energy } \\
\text { organizations }\end{array}$ & $\begin{array}{ll}\text { - } & \text { Municipal } \\
\text { facilities } \\
\text { - } & \text { Schools }\end{array}$ & 4 \\
\hline Guam & TBD & TBD & TBD \\
\hline Hawaii & $\begin{array}{ll}\text { - } & \text { State agencies } \\
\text { - } & \text { Non profits }\end{array}$ & $\begin{array}{ll}- & \text { Schools K-12 } \\
- & \text { Higher } \\
& \text { Education }\end{array}$ & 4 \\
\hline Idaho & $\begin{array}{ll}- & \text { Schools } \\
\text { - } & \text { Local } \\
& \text { Government } \\
\text { - } & \text { University }\end{array}$ & $\begin{array}{ll}\text { - } & \text { Schools } \\
\text { - } & \text { Local } \\
& \text { Government } \\
\text { - } & \text { University } \\
\text { - } & \text { Commercial } \\
\text { - } & \text { Other }\end{array}$ & 4 \\
\hline $\begin{array}{l}\text { Native } \\
\text { American } \\
\text { Nations }\end{array}$ & $\begin{array}{l}\text { Native } \\
\text { American } \\
\text { Nations/organ- } \\
\text { izations }\end{array}$ & $\begin{array}{ll}\text { - } & \text { Residential } \\
\text { - } & \text { Commercial } \\
\text { - } & \text { Casinos } \\
\text { - } & \text { Others TBD }\end{array}$ & 4 \\
\hline Nevada & $\begin{array}{ll}- & \text { Cities } \\
- & \text { Counties } \\
- & \text { Colleges } \\
\text { - } & \text { Universities } \\
\text { - } & \text { School } \\
& \text { districts }\end{array}$ & $\begin{array}{ll}- & \text { Casinos } \\
\text { - } & \text { Schools } \\
\text { - } & \text { Universities }\end{array}$ & 4 \\
\hline Oregon & $\begin{array}{ll}\text { - } & \text { Local } \\
& \text { Government }\end{array}$ & $\begin{array}{ll}\text { - } & \text { Governments } \\
- & \text { Schools }\end{array}$ & 3 \\
\hline
\end{tabular}




\begin{tabular}{|c|c|c|c|}
\hline & $\begin{array}{ll}- & \text { School } \\
& \text { districts } \\
\text { - } & \text { Universities } \\
\text { - } & \text { Utilities }\end{array}$ & $\begin{array}{ll}- & \text { Universities } \\
\text { - } & \text { Multifamily } \\
\text { - } & \text { Commercial }\end{array}$ & \\
\hline Washington & $\begin{array}{ll}\text { - } & \text { School } \\
\text { districts } \\
\text { - } & \text { State agencies } \\
\text { - } & \text { Colleges/ } \\
& \text { universities } \\
\text { - } & \text { Native } \\
\text { American } \\
\text { tribes/ } \\
\text { organizations }\end{array}$ & $\begin{array}{ll}- & \text { schools and } \\
\text { - } & \text { universities } \\
\text { - } & \text { state facilities } \\
\text { - } & \text { housing } \\
& \text { commercial }\end{array}$ & 6 \\
\hline $\begin{array}{l}\text { Regional } \\
\text { Total }\end{array}$ & & & 33 \\
\hline
\end{tabular}

\section{Customer Service}

The key to success in the region is the quality of service the Rebuild team provides to our partners and partnerships. Over the next year, the Regional Team will look to create, document and apply opportunities for enhancing our customer service. Key services to be provided to existing Rebuild Partnerships include:

a. Partnership Formation We are committed to helping our partners form partnerships and expand existing partnerships. One approach for expanding partnerships is to conduct Partnership Formation Workshops in various communities throughout the region. Requested through the regular Technical Assistance process, this workshop is a relatively standard training course designed to teach lead partners how to identify potential partners, conduct partnership formation meetings, explain the benefits of the program, and convince candidate organizations to participate in the program. We have established the following partnership development targets for 2000 .

\begin{tabular}{|c|c|c|}
\hline State/Entity & $\begin{array}{l}\text { Number } \\
\text { targeted } \\
\text { for } \\
\text { Special } \\
\text { Attention }\end{array}$ & Partnerships to be Targeted \\
\hline Alaska & 3 & $\begin{array}{ll}- & \text { RACE } \\
\text { - } & \text { University of AK } \\
\text { - } & \text { Seafood Processors }\end{array}$ \\
\hline
\end{tabular}




\begin{tabular}{|c|c|c|}
\hline American Samoa & 1 & TBD \\
\hline Arizona & at least 1 & - $\quad$ Rebuild AZ \\
\hline California & 5 & $\begin{array}{ll}\text { - } & \text { San Diego Regional Energy } \\
\text { - } & \text { Office } \\
& \text { California Energy } \\
\text { - } & \text { Commission } \\
\text { Sacramento Municipal } \\
\text { - } \quad \text { Utility District } \\
\text { - } \quad \text { San Jose } \\
\quad \text { Los Angeles }\end{array}$ \\
\hline Guam & TBD & TBD \\
\hline Hawaii & 1 & All \\
\hline Idaho & $\begin{array}{l}\text { All current } \\
\text { and new } \\
\text { partnerships }\end{array}$ & $\begin{array}{ll}-\quad & \text { current partnerships } \\
- & \text { new partnerships TBD }\end{array}$ \\
\hline $\begin{array}{l}\text { Native American } \\
\text { Nations }\end{array}$ & $\begin{array}{l}\text { All } \\
\text { partnerships }\end{array}$ & $\begin{array}{ll}- & \text { Yavapai } \\
- & \text { Havasupai } \\
- & \text { Other new recruits TBD }\end{array}$ \\
\hline Nevada & up to 2 & TBD \\
\hline Oregon & 3 & $\begin{array}{ll}\text { - } & \text { Springfield PUD } \\
\text { - } & \text { Portland General Electric } \\
\text { - } & \text { Native American } \\
& \text { partnerships } \\
\text { - } & \text { City of Lafayette } \\
\text { - } & \text { City of Wilsonville }\end{array}$ \\
\hline Washington & Up to 10 & $\begin{array}{l}\text { - All new partnerships to be } \\
\text { recruited in } 2000 \\
\text { other existing partnerships } \\
\text { TBD }\end{array}$ \\
\hline
\end{tabular}

b. Action Plans. Another challenge to the Regional Team is to increase 
implementation of Action Plans. The development of an Action Plan is often a great hurdle faced by partnerships because it requires time to develop. Program Representatives will provide ongoing assistance to partnerships in the development of their Action Plans. However, a partnership needs to take the lead in this process to determine the goals and strategies appropriate for their community. The Regional Team will assist Program Representatives as appropriate in this process. If several partnerships within a limited geographic area are developing Action Plans, the Regional Team Leader will help the assigned Program Representative(s) set up an Action Plan workshop for these partnerships and their key partners.

As part of the process of helping partnerships develop viable, self-sustaining Action Plans, Program Representatives will determine the extent to which partners are linked with resources from other community-oriented funding sources such as Community Development Block Grants, the Million Solar Roof Initiative, the Empowerment Zone/Enterprise Community programs, Energy Star, etc.

Appropriate linkages will be recommended where they do not currently exist. Special attention will be given to helping partnerships developing a strategy to be self-sustaining financially using resources from partners and the community, other federal programs and initiatives and foundations and other sources (see paragraph e. below for additional detail)

Following completion of the Action Plan, the Program Representative will forward it to Amy Tilton (at amy.tilton@pnl.gov or fax (509) 372-4990) who will coordinate the review and comment process. If requested by the partnership, the Regional Team Leader will review and comment on the Action Plan before it is submitted for comment. Once the Action Plan is reviewed and changes (if any) are made by the lead partner, it will be posted on the Information Management System.

c. Peer Exchange Key staff in Rebuild America partnerships are a great asset that can help their peers develop strong viable partnerships. The region will continue to seek out and utilize opportunities to use peers to provide assistance to peers. The region is committed to supporting ongoing Rebuild Peer Exchange by; 1) holding regional meetings twice a year; 2) supporting joint partnership proposals to foundations or other sources; 3 ) reimbursing certain travel costs for partners not funded by DOE to attend peer exchange events; and, 4) supporting web-based communication.

d. Energy Smart Schools. In November, 1999 the Department of Energy will announce plans to address the comprehensive needs of schools through this initiative as part of the Rebuild America. As soon as details of this announcement are known, DOE will work with members of the Regional Team will develop a work plan on how Energy Smart Schools Initiative will be carried 
out in this region as part of the Rebuild America Program.

e. Addressing the Unique Needs of Native American Led Rebuild Partnerships. To date we have recruited three Native American led partnerships in our region one in the Northwest and two in Arizona. A number of other native organizations have expressed an interest in joining the program. In 2000 we want to learn more about the needs, cultures, and opportunities to work with Native American organizations in our region so that we can 1) creatively serve the needs of our existing partnerships; 2) selectively recruit new partnerships like to develop successful projects. Our efforts regard are expected to focus on 1) establishing a Native American Information and resource network in the Pacific Northwest, 2) recruitment of Native American tribes in Oregon, Washington, Arizona and Idaho; and 3) Developing a close working relationship with the Bureau of Indian Affairs; and 4) developing a close working relationship with the Intertribal Council of Arizona to support partnership needs Arizona

f. State and Local Products/Services/Resources State and local resources available to Rebuild America partners were extensively researched and documented by the Regional Team in 1999. Depending on funding available in 2000 , a searchable database of these resources may be developed to assist partners in locating local sources of funding and technical assistance that match their needs. Rebuild America is a community-based program. Local resources should be pursued before partners request access to Federal resources. Program Representatives will suggest candidate existing state/local products and services that could be utilized by the Rebuild America program by notifying the IMS or Shannan Butler at 509-372-4292.

g. Finding Funding. This will remain a major focus of activity in 2000. Many of our partnerships have a strong ongoing need and interest in identifying and pursuing funding to cover the costs of administering their projects. To address this need, the region will provide the following services to our partnerships: 1) twice monthly updates of currently open financial assistance solicitations available from Federal agencies and Foundations offering funding opportunities for communities; 2) use of our Foundation Center software which contains an upto-date data base of 47,000 foundation and corporate givers who could potentially provide funding for community projects; 3 ) provide letters of support, or other appropriate assistance, for partnership proposals; and 4) inform our partnerships of the types of assistance that will be available from Rebuild America Financial Services, and serve as a catalyst to bring these services to our partnerships.

We will seek out and distribute information on how to integrate information from these sources to secure project funding and funding for staff resources for our Rebuild partnerships.

h. Regional Conference. We will explore the possibility of holding a regional 
conference in 2000. One potential focus for this conference could be the diverse needs of communities and the role that Rebuild can play to marshal resources from various locations to meet these diverse community needs.

i. Assistance From the National Program When partnerships need program assistance that is not available on a local, state or regional basis, Program Representatives shall request assistance from the National Team. This request should be submitted by phone or e-mail to Don Fort at the Energy Efficiency and Renewable Energy Clearinghouse (EREC) at 1-800-DOE-EREC; or dfort@NCIINC.com

j. Training and Program Representative Development. The Regional Team will work with appropriate members of the National Team to arrange and host on an as needed basis training sessions for Rebuild America partners and as well as Program Representative Development sessions for Regional Team members. Specific needs will be identified by the Regional Team but are expected to include: 1) FEDS; 2) monitoring and verification; 3) Life Cycle Cost Analysis; 4) resource efficient operations and maintenance; 5) building commissioning and retrocommissioning; 6) marketing; 7) financing options and opportunities through Rebuild America Financial Services; and 8) meeting facilitation.

\section{Documenting, Recognizing and Sharing Our Successes}

The true test of the success of the Rebuild America Program will be the results that we achieve. We are committed to providing assistance to our partnerships in the following manner to help them capture their results and formally recognize those who succeed.

a. Performance Monitoring Individual partners will be encouraged to track the energy savings achieved after retrofit projects are completed. The National Team is currently developing a guidebook to assist partners with some of the more difficult aspects of measurement and verification, such as interpreting utility bills, measuring data, and adjusting for weather effects. If performance contracting is used by a partner, the Energy Services Company (ESCO) will usually monitor the energy and cost savings resulting from energy conservation measures as part of their contract. DOE's Federal Energy Management Program (FEMP) has established guidelines for developing measurement and verification techniques for projects with various levels of financial investment, complexity, and risk. These guidelines can be downloaded from the FEMP Web Site at http://eande.lbl.gov/CBS/femp/MVdoc.html. The Regional Team Leader is responsible for tracking energy savings at the Regional level, and will work with partners that require assistance making measurements or calculating energy savings. Technical assistance from the National Laboratories may be available for particularly complex situations.

The indirect benefits of energy efficiency will be tracked using the Rebuild 
America Information Management System. The National Team will develop a methodology for calculating economic and environmental benefits that flow to the community, state, region, and nation. Partners will only be responsible for entering energy and cost savings data into the IMS. The internal software will perform the remaining calculations for the partner and display the results in a user friendly format. This information may then be used by partners to promote their accomplishments and expand the program in their community.

b. Reporting. Progress of all partnerships will be continuously tracked and reported to the Regional and National Teams. In late 1999 and early 2000, the Regional Team will undertake a major effort to gather performance metrics on each partnership and information on their needs and willing to share their expertise and lessons learned with others through peer exchange. This information will be gathered in a spreadsheet developed by DOE. The data will then be entered into the revised IMS This information will be updated on at least a quarterly basis. Additionally, DOE contractors and State Energy Offices will submit additional reports as prescribed by the terms of their contracts or grant.

Individual partnerships will be encouraged to visit the IMS frequently and submit updates to their partnership status whenever necessary. The IMS is an important tool for tracking results of all partnerships in one convenient location, so that the lessons learned by one partnership can help others avoid pitfalls and achieve successful results. The IMS is only useful to partners if it contains accurate and complete information. If necessary, Program Representatives will help partners obtain a password and learn to use the IMS.

c. Regional Certificates. As our regional Rebuild partnerships add new community partners, we propose to create formal partnership certificates (to be signed by the State Energy Office Director or Regional Office Director). These certificates will include the names of both the existing partnership and the new partner, and can be framed and displayed by partners to promote their involvement with the program. In return, new partners will be asked to submit an informal registration form through their lead partner. This document should identify the contribution the organization will make to the partnership, which in turn will make the process of developing and implementing an Action Plan much easier for the lead partner. Program Representatives will be responsible for collecting these letters from lead partners, requesting certificates and presenting certificates to new partners.

d. Regional Awards Annual awards for our region will be presented to one partnership and one partner for outstanding leadership and commitment to the mission of Rebuild America. Program Representatives may nominate one or more of their partners for these awards. The Regional Team will select the award recipients by voting for their top three choices in each category. The Regional Team Leader will determine the winners, and have special award plaques created. 
The awards will be presented at one of our twice yearly regional peer exchange meetings.

e. Close-Ups and Cases- In Point. Partnerships that make significant progress toward implementing their Action Plans will be recognized in Close-ups (formerly known as Success stories). Cases-in-Point (case studies) will also be prepared to provide in-depth treatment of successful projects in partnerships.

The Regional Team is committed to helping develop the following Close-ups in 2000.

\begin{tabular}{|c|c|c|}
\hline State/Entity & Number & Likely Targets \\
\hline Alaska & 3 & TBD \\
\hline American Samoa & TBD & TBD \\
\hline Arizona & 2 & $\begin{array}{l}\text { Two projects in the } \\
\text { Rebuild AZ partnership }\end{array}$ \\
\hline California & 3 & $\begin{array}{ll}- & \text { City of San Diego } \\
- & \text { County of San Diego } \\
- & \text { California Energy } \\
& \text { Commission } \\
\end{array}$ \\
\hline Guam & TBD & TBD \\
\hline Hawaii & 3 & $\begin{array}{ll}- & \text { HI DBEDT } \\
- & \text { County of Kauai } \\
- & \text { County of HI } \\
- & \text { HECO Inc } \\
- & \text { Rebuild HI Consortium } \\
\end{array}$ \\
\hline Idaho & 3 & $\begin{array}{ll}- & \text { Idaho State University } \\
- & \text { Idaho Falls School } \\
& \text { District } \\
- & \text { City Of Caldwell }\end{array}$ \\
\hline $\begin{array}{l}\text { Native American } \\
\text { Nations }\end{array}$ & 2 & TBD \\
\hline Nevada & 2 & 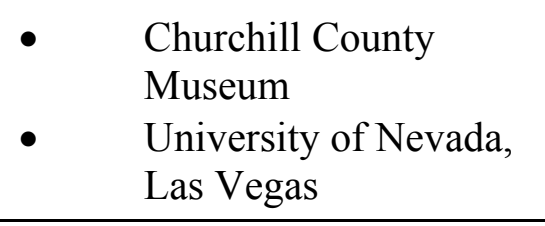 \\
\hline Oregon & 2 & Oregon State parks \& \\
\hline
\end{tabular}




\begin{tabular}{|c|c|c|}
\hline & & Recreation \\
\hline Washington & 3 & $\begin{array}{ll}\text { - } & \text { School and University } \\
\text { - } & \text { Focused Projects } \\
\text { Others TBD }\end{array}$ \\
\hline Total & at least 21 & \\
\hline
\end{tabular}

In addition, we commit to supporting at least 8 Cases-in-Point of projects in partnerships in our region.

f. Press Relations. Program Representatives are committed to helping partners promote their Rebuild America accomplishments through both trade publications and the mainstream media, including building industry journals, technical and scientific journals, climate change newsletters, and articles in newspapers, magazines, and on the World Wide Web. Such publicity supports the program by communicating partner accomplishments that can be duplicated by other communities around the country, and by marketing the program to potential new partners. Rebuild America can assist partners and Program Representatives by providing media kits, sample press releases, public service announcements, and other media relations tools. Requests for any of the media/press materials $\mathrm{s}$ mentioned above will be directed to any of Rebuild America staff at D\&R. Program Representatives will forward partnership-related press clippings to the D\&R Rebuild staff so that they can to track the effectiveness of the Rebuild America marketing campaign.

\section{Maintaining Communications}

We will rely on several different ways to ensure good communications amongst members of our Regional Team and our partnerships, and between our Region and the rest of the country. These include:

a. The Regional Team Conference Call held the first Tuesday of the month is an opportunity for states and Program Rep from our region to receive updates on national and regional program developments and offer comments on regional issues and opportunities.

b. Regional Peer Exchange meetings, held twice a year will be a great forum to exchange information and ideas and program updates amongst partnerships in our Region. We will schedule Regional Team meetings to discuss items of interest to our DOE states and our Program Reps in conjunction with these peer exchange meetings.

c. Phone and e-mail contact will be maintained on matters relating to Rebuild. It is expected that this contact will occur on at least a weekly basis. Phone contact will be the major means used by Program representatives to keep in touch with partnerships. This contact will occur no less frequently than on a monthly basis. We also expect to provide regional e-mail updates to all our partnerships on about 
a monthly basis.

\section{E. Major Milestones}

\begin{tabular}{|c|c|}
\hline Activity & Target Date \\
\hline $\begin{array}{l}\text { 1. Marketing Activities } \\
\text { - Market the Program } \\
\text { - Recruit partners/partnerships }\end{array}$ & $\begin{array}{l}\text { Ongoing } \\
\text { Ongoing }\end{array}$ \\
\hline $\begin{array}{l}\text { 2. Customer Service Activities } \\
\text { a. Partnership Formation Meetings } \\
\text { b. Action Plan Submission } \\
\text { c. } \quad \text { Peer exchange } \\
\text { - Regional Meetings } \\
\text { - Peer-to-peer assistance } \\
\text { - Joint proposals } \\
\text { d. } \quad \text { Energy Smart Schools workplan } \\
\text { e. } \quad \text { Native American Needs } \\
\text { - Develop network in the Northwest } \\
\text { - Recruit Intertribal Council of AZ } \\
\text { f. } \quad \text { Document State/Local Resources } \\
\text { g. } \quad \text { Finding Funding } \\
\text { - solicitation updates } \\
\text { h. Regional Conference } \\
\text { i. Provide assistance to partnerships } \\
\text { j. } \quad \text { Training and Program Representative Develop. } \\
\quad \text { - Training sessions for partnerships } \\
\quad \text { - Regional Rep Develop. Meeting }\end{array}$ & $\begin{array}{l}\text { Ongoing } \\
\text { Ongoing } \\
\text { Winter/Fall } 2000 \\
\text { Ongoing } \\
9 / 00 \\
3 / 00 \\
6 / 00 \\
4 / 00 \\
\text { TBD } \\
\text { biweekly } \\
\text { Fall } 00 \\
\text { ongoing } \\
\text { TBD } \\
\text { early } 00\end{array}$ \\
\hline $\begin{array}{l}\text { 3. Document Success } \\
\text { a. Complete Info on Partnership } \\
\text { Needs/Accomplishments } \\
\text { d. Regional Awards } \\
\text { e. Close-Ups; Cases in Point }\end{array}$ & $\begin{array}{l}1 / 00 \\
9 / 00 \\
\text { ongoing }\end{array}$ \\
\hline $\begin{array}{l}\text { 4. Maintain Communication } \\
\text { a. Regional Conference calls } \\
\text { c. Meet } \\
\text { d. Phone/e-mail }\end{array}$ & $\begin{array}{l}\text { monthly } \\
\text { Early } 2000 \\
\text { ongoing }\end{array}$ \\
\hline
\end{tabular}

\section{F. The Regional Team}

1. Members 
The Rebuild America Regional Team for the Far Western Region served by the Seattle Regional Support Office currently consists of the following members:

$\begin{array}{ll}\text { Paul Johnson (Team lead) } & \text { U.S. DOE - Seattle Regional Office } \\ \text { Rich Been } & \text { U.S. DOE - Seattle Regional Office } \\ \text { Laurie Brown } & \text { U.S. DOE - Seattle Regional Office } \\ \text { Eileen Yoshinaka } & \text { U.S. DOE - Seattle Regional Office } \\ \text { Doug Avery } & \text { Lawrence Berkeley National Laboratory } \\ \text { Chip Larson } & \text { Pacific Northwest National Laboratory } \\ \text { Cyane Dandridge } & \text { Strategic Energy Innovations } \\ \text { Kurt Kammerer } & \text { San Diego Regional Energy Office } \\ \text { Rebecca Garrett } & \text { AK Dept. of Community and Regional Affairs } \\ \text { Jeff Schively } & \text { American Samoa } \\ \text { Jim Westberg } & \text { AZ Dept. of Commerce } \\ \text { TBD } & \text { CA Energy Commission } \\ \text { Fred Camacho } & \text { GU Energy Office } \\ \text { Liz Raman } & \text { HI Dept of Bus., Economic Devel. \& Tourism } \\ \text { Sue Seifert } & \text { ID Dept. Of Water Resources } \\ \text { Ken Baker } & \text { ID Dept. Of Water Resources } \\ \text { Paul Normandie } & \text { NV State Energy Office } \\ \text { Sharon Hanson } & \text { OR Office of Energy } \\ \text { Scott Wolf } & \text { WA State University }\end{array}$

2. $\quad$ Roles and Responsibilities

Most of the policies and procedures developed will be established by consensus of the Regional Team and implemented by all team members. However, each team member has individual responsibilities and areas of concentration. These roles and responsibilities may change as the program evolves.

\begin{tabular}{||c|c||}
\hline \multicolumn{2}{|c||}{ Regional Team Responsibilities } \\
\hline Team Member & \multicolumn{1}{c|}{ General Responsibilities } \\
\hline Paul Johnson & $\begin{array}{l}\text { - Serve as Regional Team Leader } \\
\text { - Serve as Program Representative for assigned } \\
\text { partnerships } \\
\text { - Assign and coordinate Program Representatives } \\
\text { - Provide support to help strengthen state energy office } \\
\\
\text { involvement in the program } \\
\text { - Help Program Representatives overcome obstacles } \\
\text { - Develop Regional Marketing and Customer Service } \\
\\
\text { - Plan } \\
\text { - Establish regional goals and objectives } \\
\text { - Track progress toward goals } \\
\text { - Support and champion Regional Peer Exchanges }\end{array}$ \\
\hline
\end{tabular}




\begin{tabular}{|c|c|}
\hline & $\begin{array}{l}\text { - Conduct regional workshops and training sessions } \\
\text { - Coordinate activities with related programs (FEMP, } \\
\text { Million Solar Roofs, Weatherization, Clean Cities, } \\
\text { Energy Star) } \\
\text { - Prepare regional success stories / promotional material } \\
\text { - Interface with the National Program Team }\end{array}$ \\
\hline Rich Been & $\begin{array}{l}\text { - Serve as Regional Lead for Energy Smart Schools } \\
\text { - Program Representative for assigned partnerships } \\
\text { - Assist in procurement activities } \\
\text { - Administer Special Project grants } \\
\text { - Help prepare regional success stories / promotional material } \\
\text { - Backup for Regional Team Leader }\end{array}$ \\
\hline Laurie Brown & $\begin{array}{l}\text { - Serve as Program Representative for assigned } \\
\text { partnerships } \\
\text { - Provides partnerships information, assistance and } \\
\text { ideas to identify and pursue funding opportunities. } \\
\text { - Assist in procurement activities } \\
\text { - Administer Special Project grants } \\
\text { - Help prepare regional success stories / promotional material } \\
\text { - Backup for Regional Team Leader }\end{array}$ \\
\hline Eileen Yoshinaka & $\begin{array}{l}\text { - Serve as Program Representative for assigned } \\
\text { partnerships } \\
\text { - Administer Special Project grants } \\
\text { - Help prepare regional success stories / promotional material } \\
\text { - Conduct regional workshops and training sessions } \\
\text { - Backup for Regional Team Leader }\end{array}$ \\
\hline Doug Avery & $\begin{array}{l}\text { - Serve as Program Representative for assigned } \\
\text { partnerships } \\
\text { - Serve as regional lead for Native American tribes }\end{array}$ \\
\hline Chip Larson & $\begin{array}{l}\text { - Serve as Program Representative for assigned } \\
\text { partnerships }\end{array}$ \\
\hline Cyane Dandridge & $\begin{array}{l}\text { - Serve as Program Representative for assigned partnerships } \\
\text { - Coordinate the region's peer exchange program }\end{array}$ \\
\hline $\begin{array}{l}\text { State/Territorial Energy } \\
\text { Office Staff (Rebecca } \\
\text { Garrett, Jeff Schively, Jim } \\
\text { Westberg, Kurt Kammerer, } \\
\text { Fred Camacho, Liz Raman, } \\
\text { Sue Seifert, Ken Baker, Paul } \\
\text { Nornandie. Sharon Hanson, } \\
\text { Scott Wolf, and CA Rep } \\
\text { TBD) }\end{array}$ & $\begin{array}{l}\text { - Serve as Program Representative for Projects within their } \\
\text { borders. } \\
\text { - Administer Rebuild America Financial Assistance (if } \\
\text { applicable) }\end{array}$ \\
\hline $\begin{array}{l}\text { All Program } \\
\text { Representatives }\end{array}$ & $\begin{array}{l}\text { - Recruit new partnerships } \\
\text { - Assist with Action Plan development } \\
\text { - Identify assistance needs } \\
\end{array}$ \\
\hline
\end{tabular}




\begin{tabular}{||l|l|}
\hline & $\begin{array}{l}\text { - Coordinate delivery of services } \\
\text { - Communicate regularly with partnership staff and the } \\
\text { Regional Team } \\
\text { - Develop success stories } \\
\text { - Participate in regional conference calls, meetings, } \\
\text { workshops, and conferences }\end{array}$ \\
\hline
\end{tabular}

\section{G. Regional Metrics}

We are establishing the following regional metrics for the program.

\begin{tabular}{|c|c|c|c|c|}
\hline Metric & $\begin{array}{c}\text { Actuals } \\
1 / 1 / 99\end{array}$ & $\begin{array}{c}\text { By } \\
1 / 1 / 00\end{array}$ & $\begin{array}{c}\text { By } \\
1 / 1 / 01\end{array}$ & t Goal for 2000 \\
\hline \multicolumn{5}{|l|}{ Regional partnerships } \\
\hline A. Total & & & $1 *$ & $*$ \\
\hline \multicolumn{5}{|l|}{ B. Developed Action Plans } \\
\hline \multicolumn{5}{|l|}{ C. Have Not Developed Action Plans } \\
\hline \multicolumn{5}{|l|}{ D. In Implementation Phase } \\
\hline \multicolumn{5}{|l|}{ E. Addressing Schools } \\
\hline \multicolumn{5}{|l|}{ F. Serving As "Gateway" Program } \\
\hline Metric & $\begin{array}{r}\text { Actuals } \\
1 / 1 / 99\end{array}$ & $\begin{array}{r}\text { By } \\
1 / 1 / 00\end{array}$ & $\begin{array}{r}\text { By } \\
1 / 1 / 01\end{array}$ & $\begin{array}{r}\text { Net Goal } \\
\text { for } 2000\end{array}$ \\
\hline Success Stories/Close-Ups & not determined & 20 & 41 & 21 \\
\hline \multicolumn{5}{|l|}{ Partnership Performance } \\
\hline $\begin{array}{l}\text { A. Sq. Feet of Renovations- } \\
\text { Committed }\end{array}$ & not determined & $\begin{array}{r}48 \\
\text { million }\end{array}$ & $\begin{array}{r}67 \\
\text { million }\end{array}$ & $\begin{array}{r}19 \\
\text { million }\end{array}$ \\
\hline B. Sq. Feet of Renovations- Actual & not determined & $\begin{array}{r}96 \\
\text { million }\end{array}$ & $\begin{array}{r}135 \\
\text { million }\end{array}$ & $\begin{array}{r}39 \\
\text { million }\end{array}$ \\
\hline C. Investment \$ & not determined & 103 & 183 & 80 \\
\hline
\end{tabular}




\begin{tabular}{|l|r|r|r|r|}
\hline & & million & million & million \\
\hline D. Energy Savings (annual - \$) & not determined & ---- & ----- & $\begin{array}{r}\text { \$35 } \\
\text { million }\end{array}$ \\
\hline
\end{tabular}

\section{* This anticipates that 33 new partnerships recruited, 8 partnerships will drop out or be incorporated into other partnerships, leaving a net increase of 25 partnerships.}

By early 2000 we will have completed a data collection effort with our partnership to verify their performance to date. We will us the results of that effort to verify the success of our efforts to meet the January 1, 2000 performance metrics listed above.

\section{Future Directions}

As we gain experiences operating the Rebuild America Program we expect the program to change

and evolve, adding new partnerships and people, products and services, modifying approaches that haven't proven to be successful, and focusing on new priority markets. We will review and modify this plan as needed to reflect our experiences and changes in the program. 